
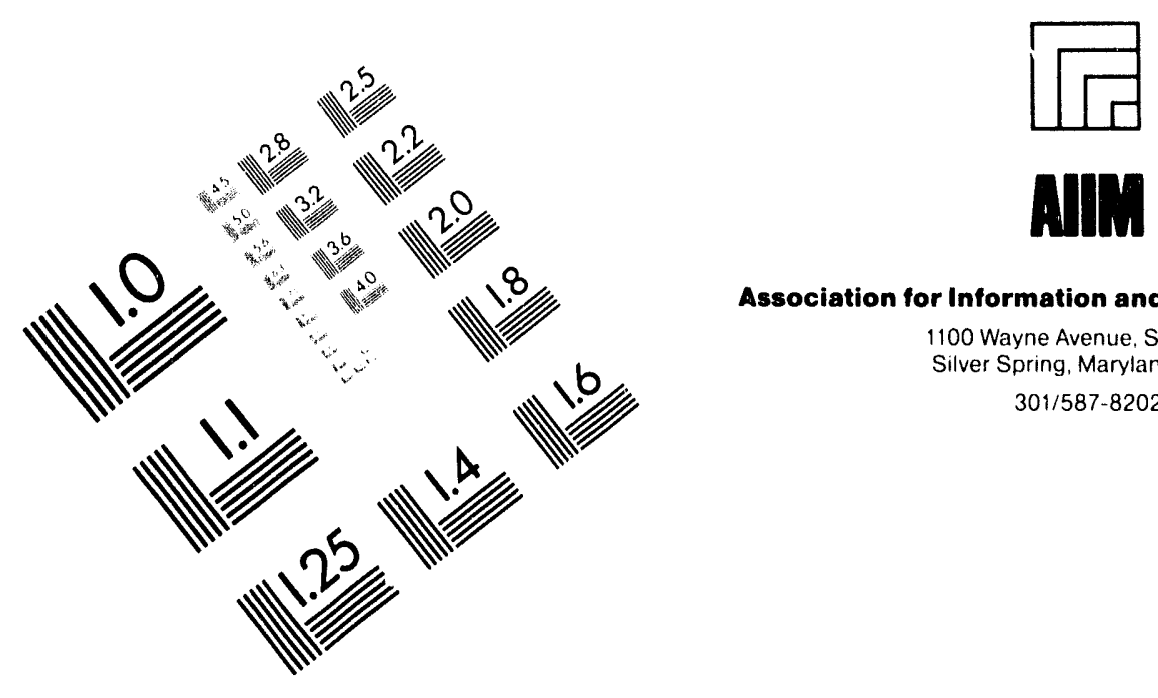

Association for Information and Image Management

1100 Wayne Avenue, Suite 1100

Silver Spring, Maryland 20910

301/587-8202

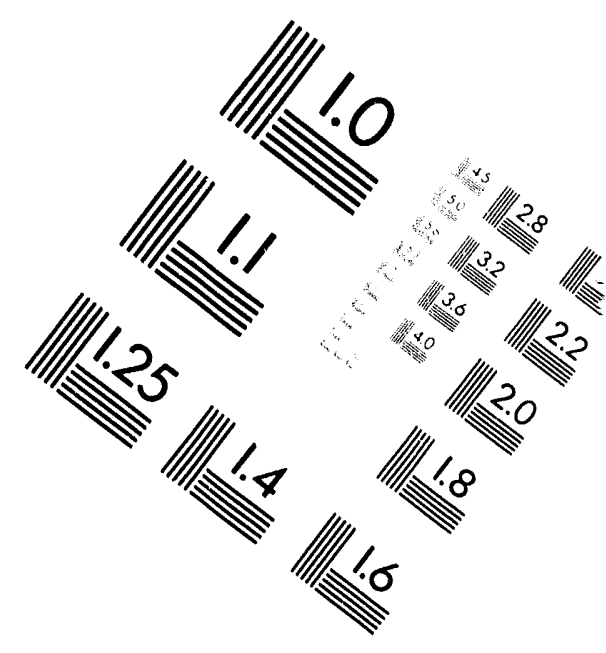

Centimeter

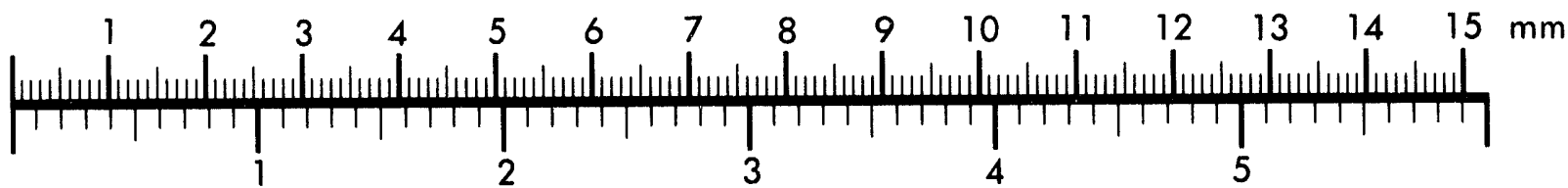
Inches
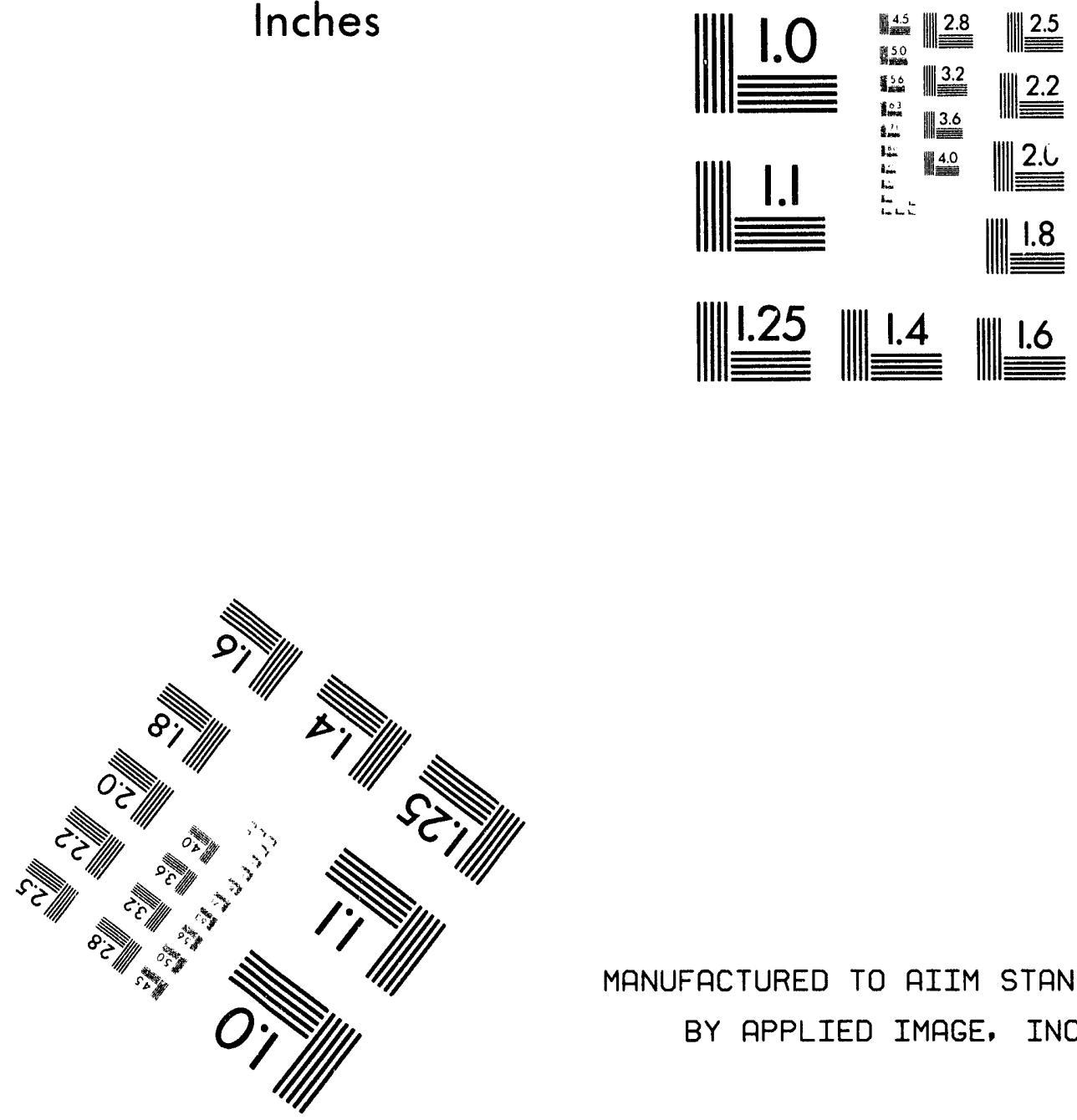

MANUFACTURED TO AIIM STANDARDS BY APPLIED IMAGE, INC.

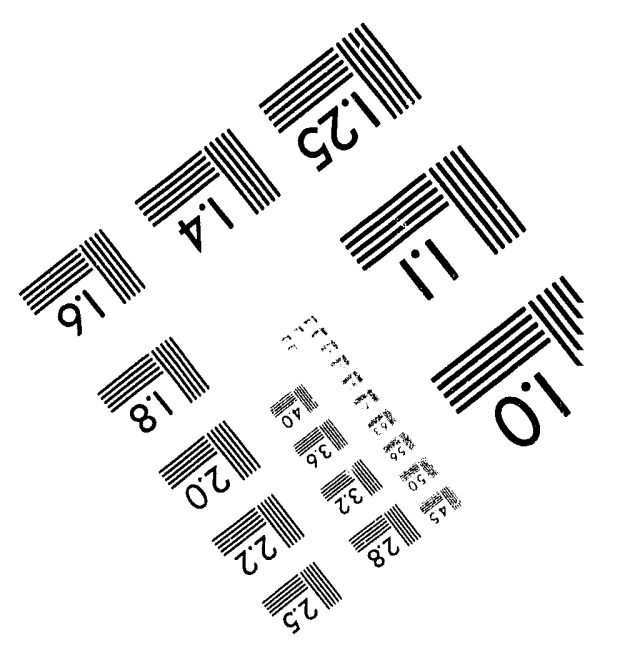



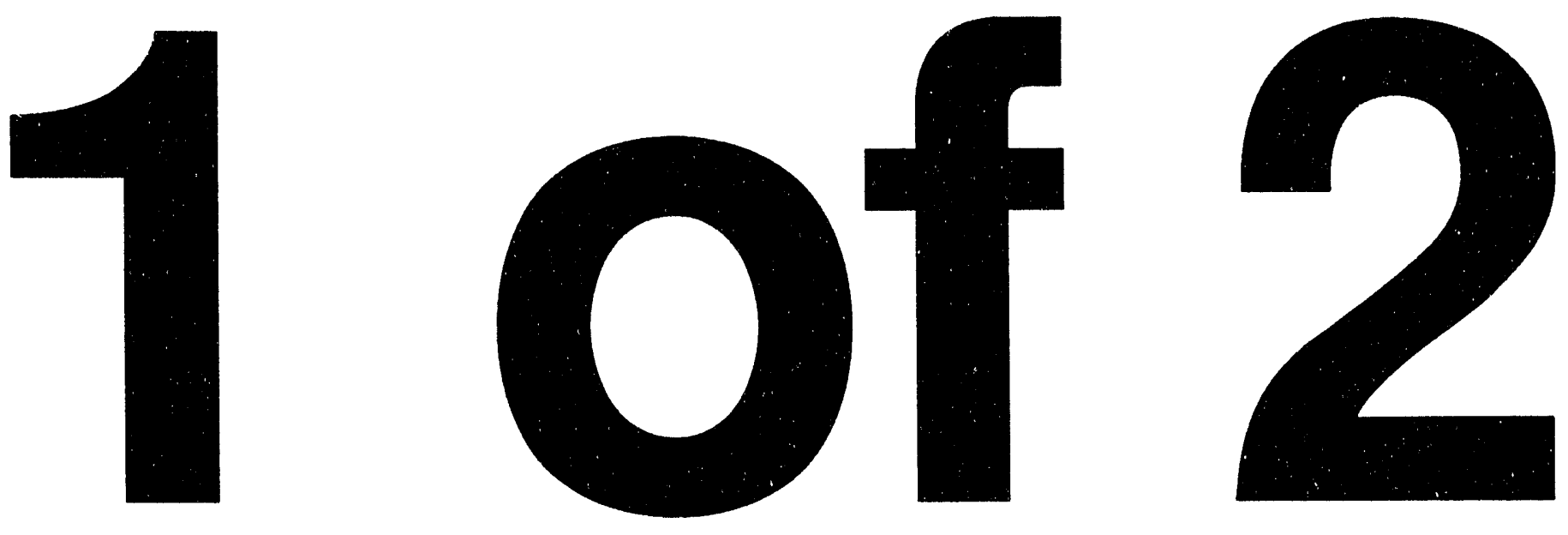


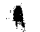

PPPL-2958

PPPL-2958

UC-425

\section{PRINCETON PLASMA PHYSICS LABORATORY (PPPL) ANNUAL SITE ENVIRONMENTAL REPORT FOR CALENDAR YEAR 1992}

BY

V.L. FINLEY AND M.A. WIECZOREK

MARCH, 1994
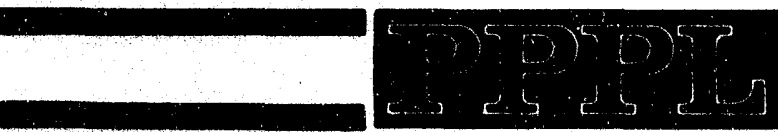

panvorton

mLapma mayoucs

Laponaromy

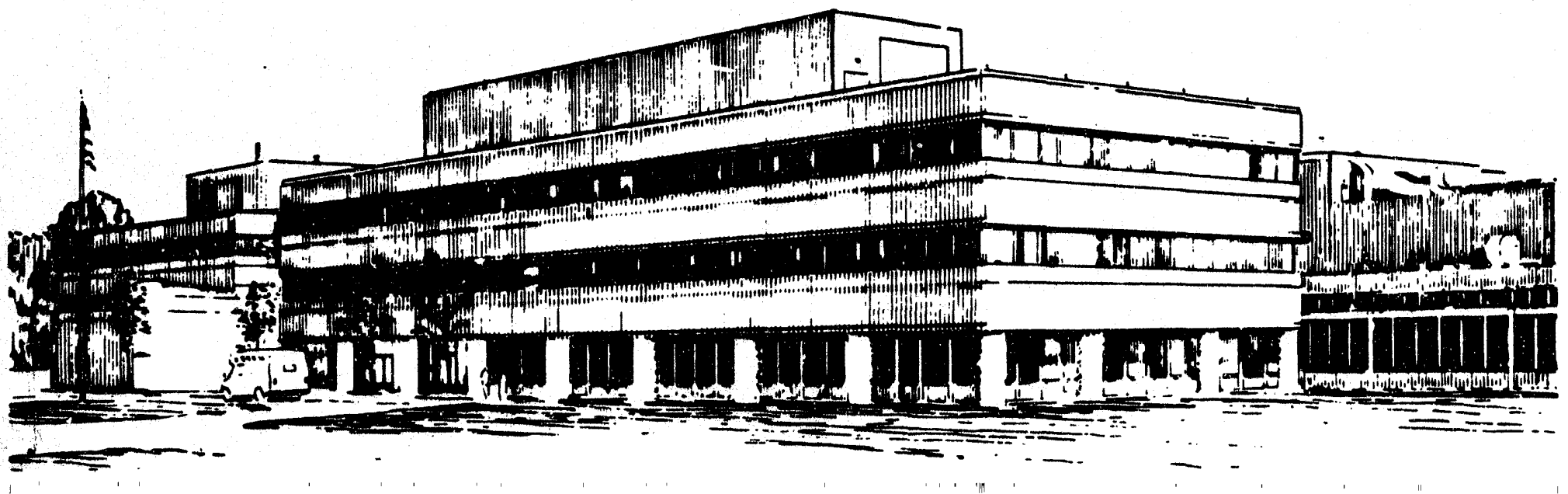




\section{NOTICE}

This report was prepared as an account of work sponsored by an agency of the United States Government. Neither the United States Government nor any agency thereof, nor any of their employees, makes any warranty, express or implied, or assumes any legal liability or responsibility for the accuracy, completeness, or usefulness of any information, apparatus, product, or process disclosed, or represents that its use would not infringe privately owned rights. Reference herein to any specific commercial produce, process, or service by trade name, trademark, manufacturer, or otherwise, does not necessarily constitute or imply its endorsement, recommendation, or favoring by the United States Government or any agency thereof. The views and opinions of authors expressed herein do not necessarily state or reflect those of the United States Government or any agency thereof.

\section{NOTICE}

This report has been reproduced from the best available copy.

Available in paper copy and microfiche.

Number of pages in this report: 146

DOE and DOE contractors can obtain copies of this report from:

Office of Scientific and Technical Information

P.O. Box 62

Oak Ridge, TN 37831 ;

(615) 576-8401.

This report is publicly available from the:

National Technical Information Service

Department of Commerce

5285 Port Royal Road

Springfield, Virginia 22161

(703) $487-4650$ 


\title{
PRINCETON PLASMA PHYSICS LABORATORY (PPPL) ANNUAL SITE ENVIRONMENTAL REPORT \\ FOR CALENDAR YEAR 1992
}

\section{B Y}

\author{
V. L. Finley \\ and
}

M. A. Wieczorek

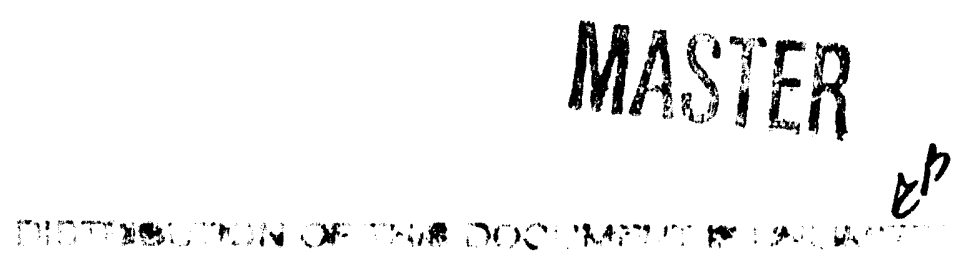




\section{Table of Contents}

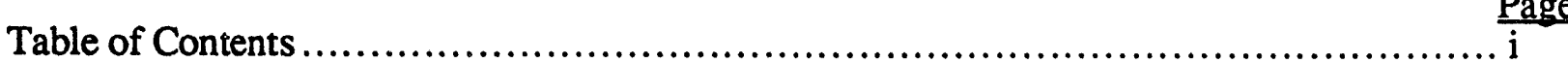

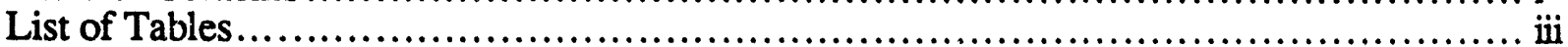

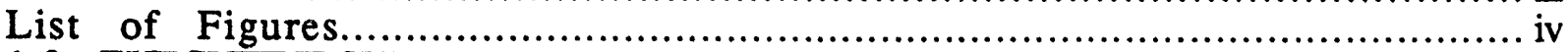

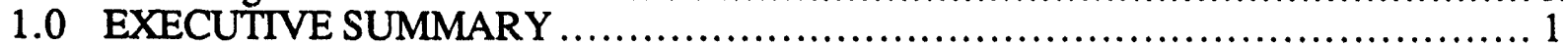

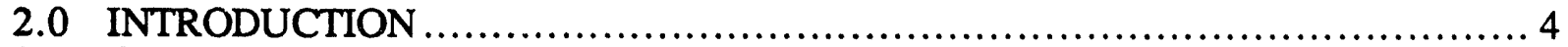

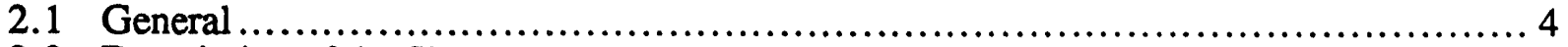

2.2 Description of the Site ........................................................... 8

3.01992 ENVIRONMENTAL COMPLIANCE SELF-ASSESSMENT $\ldots \ldots \ldots \ldots \ldots \ldots \ldots \ldots 9$

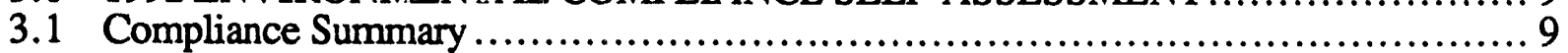

3.1.1 Comprehensive Environmental Response, Compensation, and

Liability Act (CERCLA) ................................................ 9

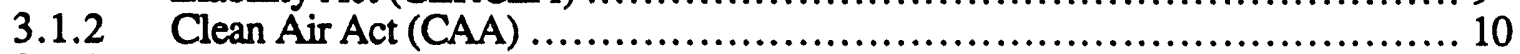

3.1.3 Clean Water Act (CWA) ................................................. 11

3.1.4 Endangered Species Act (ESA) and National Historic Preservation

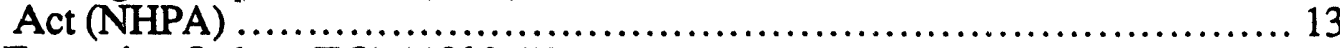

3.1.5 Executive Orders (EO) 11990 , "Protection of Wetlands" and 11988 , "Floodplain Management" ............................................... 14

3.1.6 Federal Insecticide, Fungicide, and Rodenticide Act (FIFRA) ............... 15

3.1.7 National Environmental Policy Act (NEPA) ....................................... 15

3.1.8 Resource Conservation and Recovery Act (RCRA) .......................... 16

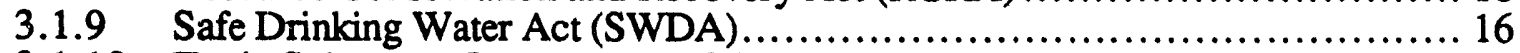

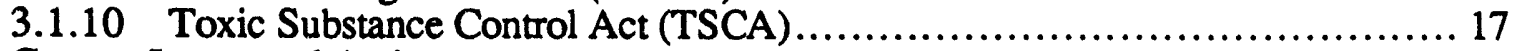

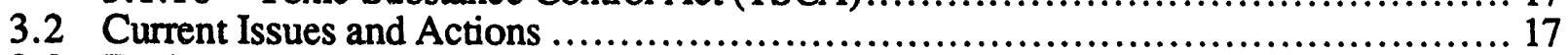

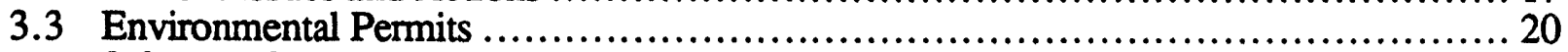

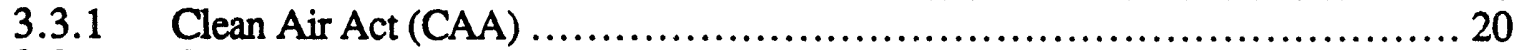

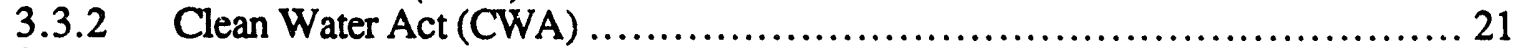

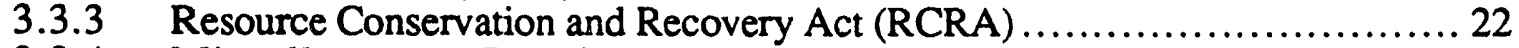

3.3.4 Miscellaneous Permits...................................................... 22

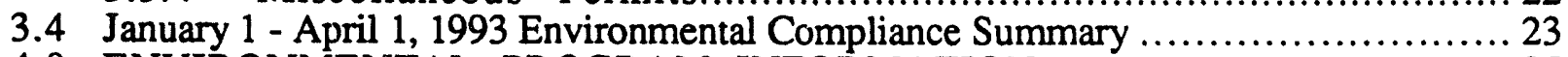

4.0 ENVIRONMENTAL PROGRAM INFORMATION.................................. 25

4.1 Assessment of Radiation Dose to the Public .............................................. 25

4.2 Assessment of Nonradioactive Pollutants ................................................ 26

4.3 Pollution Prevention and Waste Minimization....................................... 26

4.4 Regulations and Safety Criteria......................................................... 27

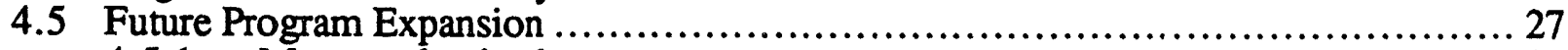

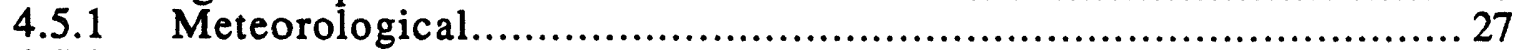

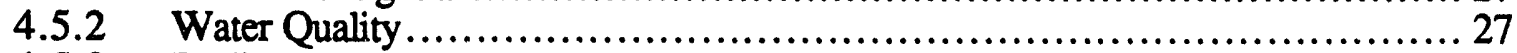

4.5.3 Radioactive Effluents................................................... 28

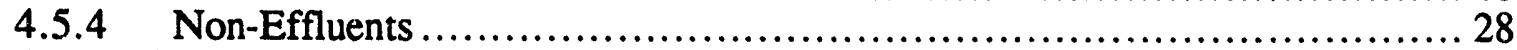

5.0 ENVIRONMENTAL RADIOLOGICAL PROGRAM INFORMATION ................ 29

5.1 Radiological Emissions and Doses...................................................... 29

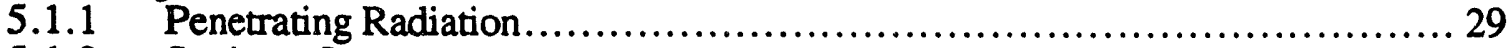

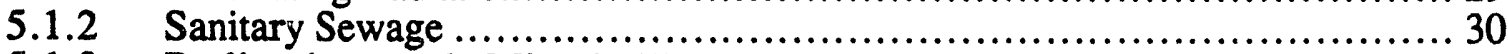

5.1.3 Radiactive and Mixed Waste...................................................... 31

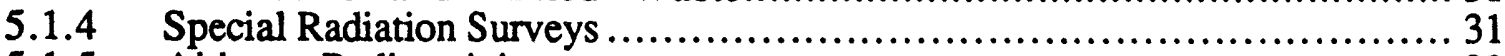

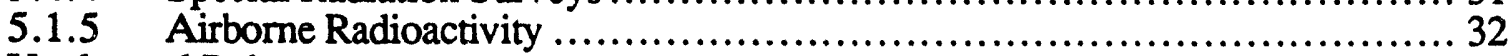

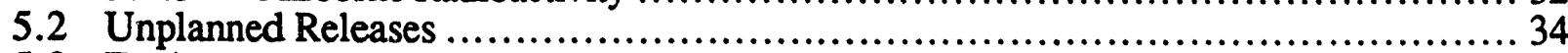

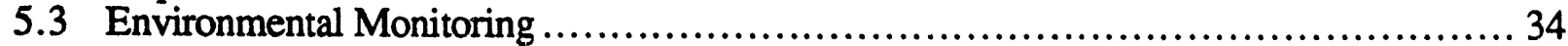

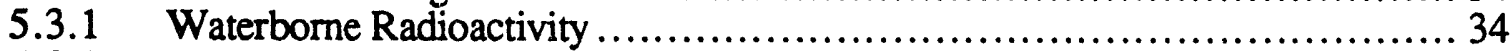

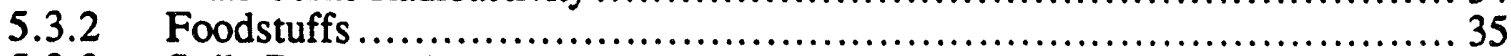

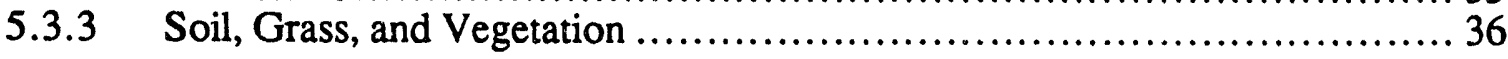


6.0 ENVIRONMENTAL NON-RADIOLOGICAL PROGRAM INFORMATION........... 37

6.1 NJPDES Data..................................................................... 37

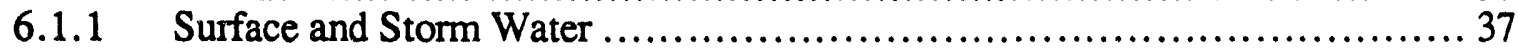

6.1.2 Groundwater Assessment.............................................. 38

6.2 Other Non-Radiological Data ...................................................... 42

6.2.1 Other Emissions Monitoring Data.......................................... 42

6.2 .2 Continuous Release Reporting ............................................... 49

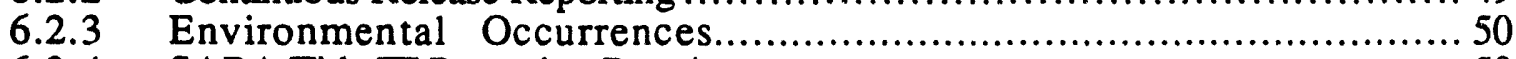

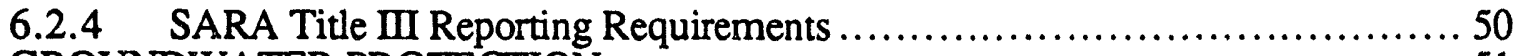

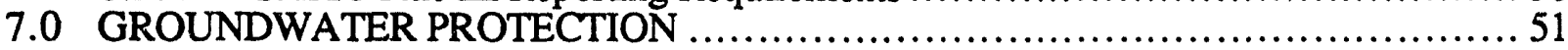

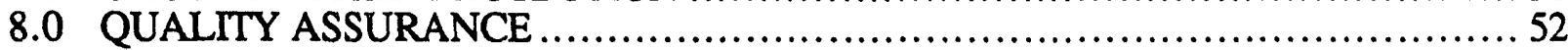

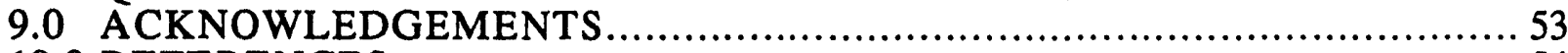

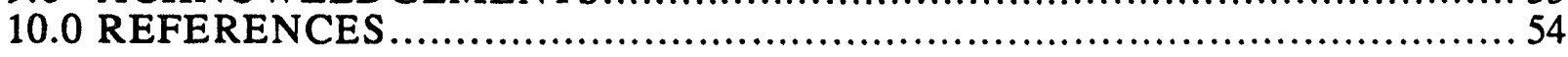




\section{List of Tables}

Table 1. TFTR Radiological Design Objectives and Regulatory Limits.................... 60

Table 2. Critical Pathways........................................................................ 61

Table 3 Monitoring Program Covering Critical Pathways .............................6 62

Table 4. Population of Municipalities Within 0-10 Miles of PPPL 1985-2010 ............6 63

Table 5. Population of Counties Within 0-50 Miles of PPPL 1985-2010 _.................6 64

Table 6. Population of Metropolitan Areas Within 50 Miles of PPPL..........................6 65

Table 7. 1995 Population Estimates Within Annular Sectors, 0-10 Miles ....................66 66

Table 8. 2000 Population Estimates Within Annular Sectors, 0-10 Miles ......................6 67

Table 9. 2005 Population Estimates Within Annular Sectors, 0-10 Miles ....................6 68

Table 10. 2010 Population Estimates Within Annular Sectors, 0-10 Miles ....................69

Table 11. 1995 Population Estimates Within Annular Sectors, 10-50 Miles...................... 70

Table 12. 2000 Population Estimates Within Annular Sectors, 10-50 Miles.......................... 71

Table 13. 2010 Population Estimates Within Annular Sectors, 10-50 Miles........................ 72

Table 14. Summary of Environmental Permits ...........................................73

Table 15. Summary of 1992 Airborne Emissions and Doses from TFTR .................. 74

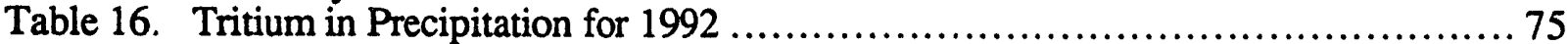

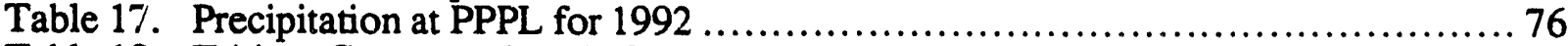

Table 18. Tritium Concentrations in Surface Water for $1992 \ldots \ldots \ldots \ldots \ldots \ldots \ldots \ldots \ldots \ldots \ldots . \ldots \ldots 77$

Table 19. Tritium Concentrations in Groundwater for 1992 _................................. 77

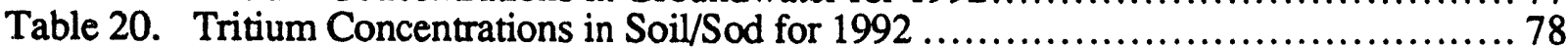

Table 21. Tritium Concentrations in Biota Moisture for 1992 .............................78

Table 22. 1992 Surface Water Analysis for Bee Brook, Locations B1 and B2................. 79

Table 23. 1992 Surface Water Analysis for D\&R Canal, C1, and Ditch \#5, D1 ............... 79

Table 24. 1992 Surface Water Analysis for Potable Water Supply, E1,

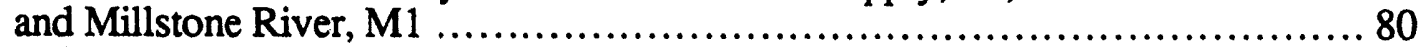

Table 25. 1992 Surface Water Analysis for Plainsboro, Locations P1 and P2 ................. 80

Table 26. 1992 Detention Basin Influent Analysis (NJPDES).................................... 80

Table 27. 1992 Monthly Surface Water Analysis for Ditch \#5, Location D2

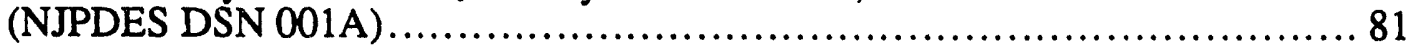

Table 28. 1992 Release Reports …..................................................... 82

Table 29. Fertilizer, Pesticides, and Herbicide Application .................................. 82

Table 30. 1992 Groundwater Elevations in UST Monitoring Wells .......................... 83

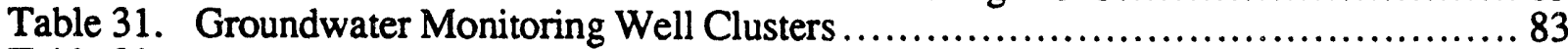

Table 32. Underground Storage Tank Monitoring Program Petroleum Hydrocarbon

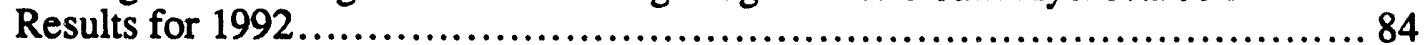

Table 33. Underground Storage Tank Monitoring Program Results - August 1992 ......... 85

Table 34. 1992 Groundwater Analysis for Well MW-14, MW-15, and MW-16................ 86

Table 35. 1992 Groundwater Analysis for Wells D-11 and D-12 _...................... 87

Table 36. 1992 Groundwater Analysis for Well TW-2 and TW-3 _........................ 87

Table 37. Groundwater Volatile Organics Analysis (May 1992) .............................. 88

Table 38. Groundwater Volatile Organics Analysis and Detention Basin Volatile Organic Analysis for August 1992

Table 39. Groundwater Base Neutral Analysis for August 1992 ................................ 90

Table 40. PPPL REML QA/QC from EPA/Las Vegas ................................. 91

Table 41. QA Sample Data .................................................................... 92 


\section{List of Figures}

Page

Figure 1. The Princeton Beta Experiment-Modification (PBX-M) ..................... 93

Figure 2. The Tokamak Fusion Test Reactor (TFTR) ....................................... 94

Figure 3. Wind Rose Joint Frequency Data for TFTR at $10 \mathrm{~m}, 1984$ to $1992 \ldots \ldots \ldots \ldots \ldots . . .95$

Figure 4. Wind Rose Joint Frequency Data for TFTR at $30 \mathrm{~m}, 1984$ to 1992 ............... 96

Figure 5. Wind Rose Joint Frequency Data for TFTR at $60 \mathrm{~m}, 1984$ to $1992 \ldots \ldots \ldots \ldots . . .97$

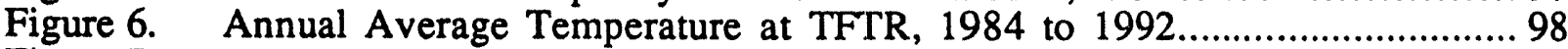

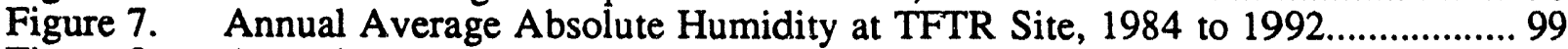

Figure 8. Annual Average Relative Humidity at TFTR Site, 1984 to $1992 \ldots \ldots \ldots \ldots \ldots \ldots . . . . .100$

Figure 9. Annual Average Wind speed at TFTR Site, 1984 to $1992 \ldots \ldots \ldots \ldots \ldots \ldots \ldots \ldots 10 . \ldots \ldots$

Figure 10. Comparison of Monthly Average Wind Speed at $30 \mathrm{~m}, 1984$ to $1992 \ldots \ldots \ldots \ldots 102$

Figure 11.

Figure 12.

Figure 13.

Figure 14.

Figure 15.

Figure 16.

Figure 17.

Figure 18.

Figure 19.

Figure 20.

Figure 21.

Figure 22.

Figure 23.

Figure 24.

Figure 25.

Figure 26.

Figure 27.

Figure 28.

Figure 29.

Figure 30.

Figure 31 .

Figure 32.

Figure 33.

Figure 34 .

Figure 35. Aerial View of the Forrestal Campus

C and D Sites of the Forrestal Campus, PPPL .................................. 104

$80 \mathrm{~km}(50$-mile) Radius of PPPL Site .......................................... 105

Immediate Site Vicinity (5 Mile Radius)........................................... 106

Layout of James Forrestal Campus ......................................... 107

1995 Population Projections Within Annular Sectors (0-10 Miles)............. 108

2000 Population Projections Within Annular Sectors (0-10 Miles).............. 109

2005 Population Projections Within Annular Sectors (0-10 Miles)............. 110

2010 Population Projections Within Annular Sectors (0-10 Miles) ............... 111

1995 Population Estimates Within Annular Sectors (10-50 Miles) .............. 112

2000 Population Estimates Within Annular Sectors (10-50 Miles) .............. 113

2005 Population Estimates Within Annular Sectors (10-50 Miles) .............. 114

2010 Population Estimates Within Annular Sectors (10-50 Miles) ............. 115

$C$ and D Site Environmental Monitoring Locations ........................... 116

Millstone River Basin Offsite Surface Water Sample Locations..................... 117

1992 Air Tritium (HTO) - TR 1-A to TR 4-A ................................... 118

1992 Air Tritium (HTO) - REAM 1-A to REAM 6-A .......................... 119

1992 Air Tritium (HT) - TR 1-A to TR 4-A ................................... 120

1992 Air Tritium (HT) - REAM 1-A to REAM 6-A ........................... 121

1992 Precipitation HTO ................................................ 122

1992 Rain Water HTO......................................................... 123

1992 Ground (Well) Water HTO.............................................. 124

1992 Tritium (HTO) Concentrations in Surface Water for Stations Bee

Brook (B1, B2,) D site (D1), Basin Discharge (D2), and Baseline................ 125

1992 Tritium (HTO) Concentrations in Surface Water for Stations

Elizabethtown Water (E1), Millstone River (M1), Devils Brook (P1, P2),

and Baseline .................................................................. 126

1992 Tritium (HTO) in Biota ............................................... 127

Figure 36. 1992 Soil Tritium (HTO) .................................................. 128

Figure 37. Monthly Water Elevations-Wells UST1, P1, and MW2 ....................... 129

Figure 38. Monthly Water Elevations-Wells MW5S, MW6S, MW7S, MW8S, and P2 .... 130

Figure 39. Monthly Water Elevations-Wells MW4, MW5I, MW6I, MW7I, and MW8I .... 131

Figure 40. Potentiometric Surface of the Bedrock Aquifer at PPPL ...................... 132

Figure 41. Potential Flow Paths of Spilled Water...................................... 133

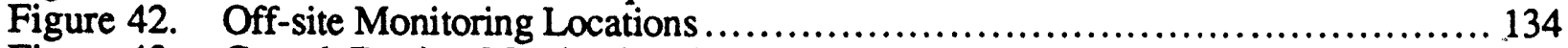

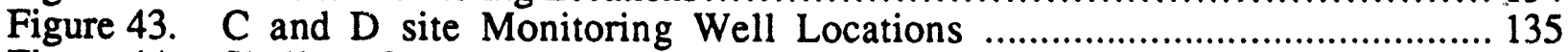

Figure 44. Shallow Groundwater Potentiometer Map, January 11, 1993................... 36

Figure 45. Intermediate Groundwater Potentiometer Map, January 11, 1993 .............. 137

Figure 46. PPPL Wetlands and Transition Area Boundaries ............................. 138 


\subsection{EXECUTIVE SUMMARY}

During Calendar Year 1992 (CY92), there were no accidents, incidents, nor occurrences that had a significant impact on the Princeton Plasma Physics Laboratory (PPPL) facilities, the environment, or program operations. The assessment of the cleanup of underground storage tank (UST) hydrocarbons discovered in 1988 continued to monitor groundwater quality in the area of the former storage tanks. As a special condition in the New Jersey Pollutant Discharge Elimination System (NJPDES) permit, PPPL conducted a groundwater assessment program on the 72 acres leased to the Department of Energy (DOE) by Princeton University. Location of the monitoring wells was based on 1) the Petrex® soil gas results [Ne90]*, which indicated solvents in several areas at the site due to past spills, 2) proximity to the USTs, and 3) the guidance of the New Jersey Department of Environmental Protection and Energy (NJDEPE). A groundwater assessment program, which began at the end of 1990 with the installation of 16 wells and two piezometers, indicated: the surface mounding effect of the open underground storage tanks (UST) excavation was driving the contamination into the groundwater; and the presence of volatile organic compounds (most probably from solvents) was found in three locations on-site. The results from this assessment were submitted to the NJDEPE in March 1991.

In 1992 NJDEPE's Bureau of State Case Management sent a draft memorandum of understanding (MOU), i.e., a voluntary agreement, to Princeton University; PPPL and the Department of Energy (DOE) had the opportunity to submit comments. The final MOU signed by Princeton University in February 1993 obligates the University to investigate the James Forrestal Campus. The remedial investigations of $A$ and $B$ sites and $C$ and $D$ sites may result in NJDEPE requiring remediation.

A waste minimization program plan was finalized in April 1992; it recognized that PPPL has implemented many steps to minimize waste, a requirement of the Resource Conservation and Recovery Act (RCRA), prior to any formal DOE requirement. The plan suggests steps to further reduce the use of hazardous materials and waste disposal requirements through the training of employees and the further assessment of waste streams. Several non-toxic cleaners were compared to solvent-based cleaners with surprisingly good results. In 1992, a process waste assessment (PWAs) procedure was prepared. It incorporated the requirements of the DOE SEN 37-90 and the New Jersey Pollution Prevention Act.

*[ ] denotes References, see pg. 53. 
Surface water analyses for both radioactive and nonradioactive pollutants have shown nothing above normally expected background values. Ambient tritium levels at less than $100 \mathrm{pCi} / \mathrm{liter}(3.7 \mathrm{~Bq} / \mathrm{liter})$ were measured in on-site well water. These data are in agreement with previous measurements by PPPL and the U.S. Geological Survey (USGS) results [St88c, St91]. Soil and vegetation samples were collected and analyzed for free water tritium as part of the continuing baseline studies. To date, no studies have been undertaken to look at organically bound tritium (OBT).

Off-site surface water, soils, and biota continued to be analyzed for radioactive baselines in CY92. Passive tritium monitors, tested in field modeling experiments in Canada in 1987 [Gr88a], were used in four on-site area monitors, one stack monitor, and one off-site monitor. Six off-site locations within $1 \mathrm{~km}$ of TFTR were installed to monitor tritium in air at these off-site stations. These differential atmospheric tritium samplers (DATS) are high sensitivity monitors that are able to detect changes in the ambient levels [Gr88b].

Radiation exposure, via airborne effluents into the environment, is at insignificant levels. A tritium stack monitor was added to the Tokamak Fusion Test Reactor (TFTR) stack even though it was not required by National Emission Standard for Hazardous Air Pollutants (NESHAPs) requirements. From deuterium-deuterium (D-D) fusion reactions during TFTR experimental operations, approximately $0.967 \mathrm{Ci}(36.1 \mathrm{GBq})$ of tritium and 1.649 $\mathrm{Ci}(61.6 \mathrm{~Bq})$ of ${ }^{41} \mathrm{Ar}$ from air activation were produced in 1992 . This amount of radionuclides was released to the air via the TFTR stack. About $0.016 \mathrm{Ci}(0.6 \mathrm{GBq})$ of tritium oxide (HTO) was released to the sanitary sewer. Prompt radiation, which is radiation emitted during operations, is detectable at extremely low-levels during high-power pulses from TFTR by using high-sensitivity instrumentation. A special study was conducted in 1990 by the DOE Environmental Measurements Laboratory (DOE/EML) to verify former PPPL Health Physics (HP) Branch measurements. The DOE/EML measurements confirmed the acceptability of HP neutron dose equivalent measurements [Ku91]. The integrated dose equivalent* at the site boundary from TFTR operations was less than $1 \mathrm{mrem}(0.01 \mathrm{mSv})$ for CY92 for measured, prompt radiation plus calculated tritium and air activation releases.

\footnotetext{
*In all cases used in this report, the whole body is the critical organ and the term dose equivalent can be considered to be synonymous with the term effective dose equivalent.
} 
PPPL has emphasized environment, safety, and health (ES\&H) in accordance with DOE requirements at all of its facilities. The expectations are that the Laboratory will excel in ES\&H as it has demonstrated in its fusion research program. The efforts are geared not only to full compliance with applicable local, state, and federal regulations, but to a level of excellence which includes state-of-the-art monitoring and best management practices. 


\subsection{INTRODUCTION}

\subsection{General}

This report gives the results of the environmental activities and monitoring programs at the Princeton Plasma Physics Laboratory (PPPL) for CY92. The report is prepared to provide the U.S. Department of Energy (DOE) and the public with information on the level of radioactive and nonradioactive pollutants, if any, added to the environment as a result of PPPL operations, as well as environmental initiatives, assessments, and programs. The objective of the Annual Site Environmental Report is to document evidence that DOE facility environmental protection programs adequately protect the environment and the public health.

The Princeton Plasma Physics Laboratory has engaged in fusion energy research since 1951. The long-range goal of the U.S. Magnetic Fusion Energy Research Program is to develop and demonstrate the practical application of fusion power as an alternate energy source. In 1992, PPPL had both of its two large tokamak devices in operation; the Tokamak Fusion Test Reactor (TFTR) and the Princeton Beta Experiment-Modification (PBX-M). PBX-M completed its new modifications and upgrades and resumed operation in November 1991. A new machine, the Tokamak Plasma Experiment (TPX), replaced the cancelled Burning Plasma Experiment (BPX) as PPPL's next machine; TPX start up is planned for the year 2000 .

The Princeton Beta Experiment (PBX), the predecessor of PBX-M, after achieving a ratio of plasma pressure to magnetic pressure in excess of $5 \%$ in CY84 experiments, was shut down at the end of 1985 to undergo modifications permitting further examination of theoretical predictions on plasma shaping and stabilization of kink modes by means of a close-fitting conducting wall. The addition of new coils and stabilizer plates within the vessel, new power supplies, and a new control system began in 1986. The modified device, PBX-M (Fig. 1), came back into operation in October 1987. In CY88, an indentation of the plasma of $25 \%$ was achieved, lower $\mathrm{q}(\mathrm{a})$ values obtained, and $\mathrm{H}$-modes at lower power attained. In CY89, the effectiveness of the passive plates in stabilizing kink modes and access to higher plasma pressure $(b \sim 6.8 \%)$ were assessed. A Safety Assessment Document (SAD) was published for the PBX in 1984 [F184], which indicated that the PBX did not pose any potential environmental concerns. A new SAD published 
for the PBX-M in 1988 reached the same conclusion [St88a]. A third SAD was approved prior to the start-up of the upgraded PBX-M in FY91 [SAD91].

The TFTR (Fig. 2), in its first full year of operation in CY83, had an increase in total neutron production in 1987 to a yearly total of $3 \times 10^{18}$ [He88], in 1988 to a yearly total of $9.04 \times 10^{18}$ [He89], in 1989 of $6.4 \times 10^{18}$ [Ja90a], in 1990 of $2.3 \times 10^{19}$ [Ja90b], in 1991 of $1.56 \times 10^{18}$ [Ja92], and in 1992 of $1.53 \times 10^{19}$ [Ja93], which was the greatest number of neutrons produced in a six-year period. The higher neutron production has increased the activation level of the machine to the point where health physics surveys are required in the test cell following a machine run and before any personnel entry is permitted for isspection, routine maintenance, or installation work. In addition, tritium from D-D reactions-which was absorbed in graphite and measured during the opening of the vessel in 1987, 1988, 1990, 1991, and 1992-posed the first known health physics contamination challenges for any tokamak operations. The experience gained from the 1987 opening was beneficial for the similar openings in 1988-89 and has helped to streamline operations for the 1990-91 and 1991-1992 openings.

The TFTR is a toroidal magnetic fusion energy research device in which a deuteriumtritium (D-T) plasma will be magnetically confined and heated to extremely high temperatures by neutral-beam injectors and radio-frequency waves. A major achievement in 1986 was an increase in neutron production and fusion power by operating in what is now called the "supershot" pulse mode. Using this technique, a new record temperature of greater than 400 million degrees Celsius has been achieved. Ion Cyclotron RadioFrequency (ICRF) heating became operational in 1988. The D-T operations were scheduled to begin in 1990; however, reprogramming and a budget cut announced in November 1988 have resulted in a schedule delay so that D-T experiments will begin in late 1993. A small amount of tritium (<1000Ci) was brought on-site in April 1993 to use in the testing of the TFTR tritium storage and cleanup systems. The safety analyses completed for this program are addressed in Safety Analysis Reports for the Project [PSAR78 and FSAR82]. In 1988, the Final Safety Analysis Report (FSAR) was being updated to reflect operational requirements and parameters using tritium. This effort was initiated again in FY91 and was completed in 1993.

Although PPPL operates $\mathrm{C}$ site as an unfenced site, with access controls for security purposes, it is considered to be open to the public for environmental purposes. The $D$ site is entirely fenced, with access controls which do not allow free access to the TFTR. This 
free access of $\mathrm{C}$ site has necessitated a thormigh evaluation of the on-site discharges, as well as the potential for off-site releases of radioactive and toxic nonradioactive effluents. An extensive monitoring program, which is tailored to these needs, has been instituted and expanded over recent years. The PPPL radiological environmental monitoring program generally follows the guidance given in two DOE reports; $\triangle$ Guide for: Environmental Radiological Surveillance at U.S. Department of Energy Installations [Co81] and Environmental Dose Assessment Methods for Normal Operations at DOE Nuclear Sites (PNL-4410) [St82]. This includes adherence to the standards given in DOE Orders, in particular, DOE Order 5400.5 [DOE90a], which pertains to permissible dose equivalents and concentration guides and gives guidance on maintaining exposures "to as low as reasonably achievable" (ALARA). On January 1, 1990, DOE Order 5480.11 guidelines came into effect [DOE89]. While this order did not have a major impact on PPPL operations, the order did incorporate some changes in personnel monitoring requirements. DOE Order 5400.1 [DOE90b] requires an environmental monitoring plan. This plan was completed in CY91 and updated in CY92. Specific criteria for implementing these standards on TFTR are contained in the TFTR Technical Safety Requirements document (OPR-R-23). These criteria are shown in Table 1.

An environmental survey was conducted in June 1988 by DOE/HQ as part of an intensive evaluation at all DOE sites. No significant environmental concerns surfaced at PPPL as a result of this audit. An oil spill in 1988 by an outside vendor led to a project of incorporating the cleanup with the removal of five underground storage tanks (USTs) and the replacement of those tanks with above ground tanks. In addition, groundwater contamination became a concern, and a Petrex® soil gas survey was accomplished over the entire site in the spring of 1990 [Ne90]. A groundwater assessment program was prompted by the results of the soil gas survey, the UST issue, and New Jersey Pollutant Discharge and Elimination System (NJPDES) permit requirements; the results of this assessment program are discussed in more detail below.

The emphasis of the radiation monitoring program has been placed on exposure pathways appropriate to fusion energy projects at PPPL. These pathways include external exposure from direct penetrating radiation; during D-T external exposure from airborne radionuclides, such as ${ }^{41} \mathrm{Ar},{ }^{13} \mathrm{~N}, 16 \mathrm{~N}$, and internal exposure from radionuclides, such as ${ }^{3} \mathrm{H}$ in air and water, will be monitored. Six major critical pathways are considered as appropriate (see Table 2). Prompt radiation, i.e., that which is emitted immediately during operations, was also considered and is being measured. The monitoring program, as 
envisioned by the TFTR Final Safety Analysis Report [FSAR82], has been updated to reflect the current environment around TFTR (see Table 3). At present, the radioactive pollutant potential to the environment by any pathway is essentially nonexistent. Small amounts of tritium are produced from D-D reactions [approximately $0.967 \mathrm{Ci}(36.1 \mathrm{GBq})$ in 1992 if all neutrons measured are assumed to be D-D produced]. A tritium monitor was installed on the TFTR stack in late 1990. Low-levels of tritium (concentrations less than levels defined as radioactive materials by the U.S Department of Transportation) are now detectable in pump oils. Also, tritiated water (HTO) is detected in the vacuum vessel air (outgassing from the carbon tiles) during the maintenance and upgrade period [St88b].

Preliminary meteorological considerations and associated methodology, which were established at the time of the installation of PPPL's first meteorological tower, were reported in Section 2 of the TFTR FSAR. Subsequently, improved methodologies were implemented, and a new meteorological tower was erected and began operation in November 1983 [Mc83]. The improved measurements and methodologies are being included in the updated FSAR being prepared for tritium operations. Data have been collected for nine years using the monitors on the new tower (Figs. 6, 7, and 8). Windrose plots from the data for the nine years (1984-92) are shown in Figs. 3, 4, and 5. A tracer gas-release test was conducted during the period from July to September 1988 to look at site-specific air-diffusion parameters. These tests were commissioned to determine actual site conditions versus model predictions in relation to future activities. The test results indicated that actual dispersion and dilution of effluents in the vicinity of PPPL are enhanced by up to a factor of 16 over that predicted by Nuclear Regulatory Commission approved standard Gaussian diffusion models [St89]. Additionally, as a result of these tracer gas-release tests, a 10-m wind speed and wind-direction sensor was added to the meteorological tower in 1990 to monitor PPPL on-site meteorology more precisely. The U.S. Environmental Protection Agency (EPA) has been petitioned through the Princeton Area Office (DOE/PAO) to use the more realistic $x / Q$ values from these tests in the AIRDOS-EPA model used for the National Emission Standard for Hazardous Air Pollutants (NESHAPs) calculations. Approval was received in 1991. 


\subsection{Description of the Site}

The Princeton Plasma Physics Laboratory is located at the C and D sites of the James Forrestal Research Campus of Princeton University (Figs. 11 and 12). As shown in Fig. 13, the location is in central New Jersey within Middlesex County. The site is surrounded by undisturbed areas with forest, open grass areas, corn fields, and a small brook (Bee Brook) running next to its eastern boundary. The closest urban centers are New Brunswick, 14 miles to the northeast, and Trenton, 12 miles to the southwest. Major metropolitan areas, including New York City, Philadelphia, and Newark, are within 50 miles of the site. As shown in Fig. 14, the municipalities of Princeton, Plainsboro, Kingston, West Windsor, and Cranbury, among others, are in the immediate vicinity of the site. Also, the main campus of Princeton University, located primarily within the Borough of Princeton, is approximately three miles to the west of the site. The general layout of the facilities at the $C$ and D sites of Forrestal Campus is indicated in Fig. 15; the specific location of TFTR is at D site.

A demographic study was completed in CY87 as part of the requirement for the Environmental Assessment for the former Burning Plasma Experiment (BPX) [Be87a]. Other information gathered and updated from previous TFTR studies included socioeconomic information [Be87b] and an ecological survey [En87]. The demographic data were based on the 1980 census and show both estimated and projected data out to the year 2010 (Tables 4 to 13 and Figs. 16 to 23) in a zone from 1 mile out to 50 miles.

The PPPL site is in the center of a highly urbanized region extending from Boston, Massachusetts, to Washington, D.C., and beyond. The previous population projections for the states of New Jersey, New York, and Pennsylvania had indicated a substantial population increase within 50 miles of the PPPL site. The actual change from 1970 to 1980 , as indicated by the census in these two years, was not as large as had been expected. In fact, the population in New York City and Philadelphia decreased. The Princeton area continues to experience a substantial increase in new business moving into the Route 1 corridor near the site. This increase, however, has not been as great as the projections had indicated. 


\subsection{ENVIRONMENTAL COMPLIANCE SELF-ASSESSMENT}

\subsection{Compliance Summary}

It is PPPL's goal to be in compliance with all applicable state, federal, and local environmental regulations. As a result of PPPL's self-assessments, DOE Chicago audits, and DOE/HQ Tiger Team action plans, PPPL continues actions to enhance its compliance efforts, especially in the area of strict documentation requirements. The status of each applicable environmental statute is listed below:

\subsubsection{Comprehensive Environmental Response. Compensation, and Liability Act (CERCLA)}

The PPPL is not involved with CERCLA mandated cleanup actions. Presently, under the requirements for SARA Title III, PPPL submits an annual inventory to be in compliance with CERCLA. As a result of the 1991 Tiger Team assessment, an action plan was developed to conduct a more comprehensive documentation for CERCLA inventory of past hazardous substances. The CERCLA inventory was completed in 1993.

\section{Emergency Planning and Community Right to Know Act. SARA Title III.}

Title III of the 1986 SARA amendments to CERCLA created a system for planning responses to emergency situations involving hazardous materials and for making information regarding the use and storage of hazardous materials available to the public. Under SARA Title III, PPPL provides to the applicable emergency response agencies: 1) an inventory of hazardous substances stored on the site; 2) Materials Safety Data Sheets (MSDS); and 3) completed SARA Tier I forms listing each hazardous substance stored by users above a certain threshold planning quantity (typically 10,000 pounds, but lower for certain compounds) to applicable emergency response agencies. The table on page 10 lists hazardous compounds at PPPL, reported under SARA Title III for 1992.

Section 304 of SARA Title III requires that the Local Emergency Planning Committee (LEPC) and state emergency planning agencies be notified of accidental or unplanned releases of certain hazardous substances to the environment. To ensure compliance with 
such notification provisions, a Laboratory-wide procedure, ESH-013, "Non-Emergency Release Notification and Reporting," includes SARA Title III requirements.

The New Jersey Department of Environmental Protection and Energy (NJDEPE) administers the SARA Title III reporting for EPA and has modified the Tier I form to include SARA Title III reporting requirements and NJDEPE reporting requirements.

\section{HAZARD CLASS OF CHEMICALS AT PPPL}

\begin{tabular}{|c|c|c|c|c|c|}
\hline Compound & Fire & $\begin{array}{l}\text { Sudden } \\
\text { Release } \\
\text { of } \\
\text { Pressure } \\
\end{array}$ & Reactive & $\begin{array}{l}\text { Acute } \\
\text { Health } \\
\text { Hazard } \\
\end{array}$ & $\begin{array}{l}\text { Chronic } \\
\text { Health } \\
\text { Hazard }\end{array}$ \\
\hline Ammonia & & $v$ & & $v$ & \\
\hline Bromotrifluoromethane & & $\boldsymbol{v}$ & & $\sigma$ & \\
\hline Carbon dioxide & & $\boldsymbol{v}$ & & $\checkmark$ & \\
\hline Dichlorodifluoromethane & & $\boldsymbol{v}$ & & $\boldsymbol{v}$ & \\
\hline Fuel Oil & $\checkmark$ & & & & \\
\hline Gasoline & $\boldsymbol{v}$ & & & & $\boldsymbol{\nu}$ \\
\hline Helium & & $\boldsymbol{v}$ & & & \\
\hline Nitrogen & - & $\boldsymbol{V}$ & & & \\
\hline Petroleum Oil & $\boldsymbol{\alpha}$ & & & & \\
\hline Polychlorinated Biphenyls & & & & & $\boldsymbol{V}$ \\
\hline Sulfur Hexafluoride & & $v$ & & & \\
\hline Sulfuric acid & & & 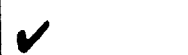 & $\boldsymbol{V}$ & \\
\hline
\end{tabular}

\subsubsection{Clean Air Act (CAA)}

The PPPL was in compliance with the requirements of the CAA in 1992. Currently in preparation, the 1992 Air Emission Survey will be sent to NJDEPE who will in turn submit the survey to the USEPA; the data will be incorporated into the national database, the Aerometric Information Retrieval System (AIRS), and Air Facility Subsystem (AFS) where it will become public information. 
As the result of a self-assessment by PPPL, the DOE Tiger Team assessment findings, and the Clean Air Act Amendments of 1990, preparation of a detailed air emission inventory was completed in May 1993. The purpose of the inventory is to estimate significant air emissions from all sources so that a manageable air control program can be established. The inventory includes air emission quantities, point and fugitive emission sources, airproducing activities, and permit applicability.

The NJDEPE conducted a facility inspection on September 2,1992; although a penalty of $\$ 400$ was assessed for the operation of two carpenter shop dust collectors without NJDEPE air certificates, the amount was negotiated down to $\$ 320$. The PPPL and DOE prepared and submitted applications for three dust collectors (particulate baghouses) located at the facility. Also, DOE submitted to NJDEPE an amendment to change the oil tank vent certificate from No. 6 oil to No. 4 oil.

PPPL has added a stack sampler to the TFTR facility for tritium releases, which has been independently verified as meeting National Emission Standard for Hazardous Air Pollutants (NESHAPs) radionuclide emission monitoring requirements. The PPPL received EPA's concurrence on this determination in August 1993 . During their inspection of PPPL facilities in March 1993, representatives from EPA Region II indicated that PPPL was in compliance with NESHAPs requirements.

\subsubsection{Clean Water Act (CWA)}

The PPPL is in compliance with all requirements of the CWA. An assessment of groundwater has been undertaken as part of an effort that followed identification of leaking underground storage tanks (USTs) containing heating oil and vehicle fuel. Quarterly monitoring reports are submitted for the underground storage tank monitoring program as required by the NJDEPE.

Awaiting renewal from NJDEPE, PPPL continues to operate under the conditions of expired New Jersey Pollutant Discharge Elimination System (NJPDES) surface water discharge permit (NJ0023922). During 1992, three non-compliances were issued: for two exceedances of the chemical oxygen demand (COD) limit (>50 mg/l), which occurred in March (66 mg/1) and in November (54 mg/1); and for one exceedance of the total suspended solid (TSS) limit (>50 mg/1), which occurred in November (140 mg/l). The March 1992 exceedance of chemical oxygen demand was investigated; the probable cause of this 
occurrence was the discharge of sediments from the $\mathrm{C}$ site $\mathrm{MG}$ heat exchangers during a flushing of those heat exchangers. Administrative controls were taken to prevent future recurrence of this kind of discharge to the detention basin. The November 1992 event, involving exceedances of TSS $(140 \mathrm{mg} / \mathrm{l})$ and COD $(54 \mathrm{mg} / \mathrm{l})$, was investigated; however, to date a definitive cause has yet to be identified.

Following the issuance of storm-water regulations in 1991, PPPL and DOE/PAO requested NJDEPE to review the site's storm-water runoff that does not drain to the detention basin. In addition, PPPL and DOE/PAO asked NJDEPE about the filter backwash discharge at the Delaware \& Raritan Canal pump house as a possible new discharge point. As a result of these inquiries, NJDEPE directed DOE/PAO to submit a NJPDES application for these discharge points; in March 1992, the application was submitted. Renewal of the Laboratory's NJPDES permit is still awaiting issuance by the NJDEPE.

A Treatment Works Approval (TWA) application was submitted to the NJDEPE for several projects: 1) Detention Basin Upgrade, 2) installation of a septic holding tank at the Calibration and Services Laboratory (CASL), and 3) permitting of the existing liquid effluent collection tanks (LEC).

The TWA for upgrade of the detention basin was submitted to NJDEPE, Bureau of Industrial Discharge Permits, in August 1992 and was approved and became effective in February 1993. The project will include the installation of an impermeable liner and under drainage system for the detention basin, the construction of upgrades to the outfall of the detention basin, the re-routing of the storm drainage from the warehouse spill containment system and the southeast quadrant switchyard, and upgrading of the oil detection system at C site. The PPPL will comply with the twelve general conditions and seventeen specific provisions of the TWA permit; the permit expires on February 25, 1995.

The TWA for the septic holding tank at the CASL was submitted to the NJDEPE in June 1992. In addition, the Stony Brook Regional Sewerage Authority (SBRSA) and Plainsboro and South Brunswick Townships received the TWA, specifically for their review and endorsements. Approval of the TWA is currently awaiting approval by SBRSA and NJDEPE.

The TWA for the liquid effluent collection (LEC) tanks was submitted to the NJDEPE in October 1992. However, NJDEPE informed PPPL in October 1992 that NJDEPE does 
not require a TWA due to the exemption status of these tanks, based on their installation date. Wastewater collection tank systems installed before 1988 are not regulated under the TWA program. The NJDEPE did inform PPPL that SBRSA will require a significant industrial user (SIU) review. Presently, PPPL is awaiting a response from SBRSA.

Under the CWA and New Jersey Discharge of Petroleum and Hazardous Substances regulation, PPPL reported three releases of petroleum, petroleum products, or hazardous substances to the NJDEPE. Of these three releases, all releases impacted permeable surfaces (gravel, sand, or soil) and involved minor amounts of petroleum products: hydraulic fluid ( $\sim 2$ gallons), mineral oil ( $<1$ gallon), and No. 6 oil $(<1$ gallon). Under guidance received from EPA and NJDEPE [NJDEPE91], releases similar to the parking lot runoff and small releases onto the pavement no longer are required to be reported, except if there is a reportable quantity under CERCLA; reporting is not required for minor releases of petroleum and hazardous substances onto impermeable surfaces that can be readily cleaned up.

During 1992, the Stony Brook Regional Sewerage Authority (SBRSA) required PPPL to submit to the SBRSA a pretreatment application and sanitary sewer survey. SBRSA issued its proposed Service Rule Revisions in early 1993; under these rule revisions, SBRSA may require PPPL to comply with a pretreatment program in which permits and associated effluent limits, pretreatment technologies, and penalties, are enforceable. Amendments to state laws, specifically the New Jersey "Water Pollution Control Act" and the "Clean Water Enforcement Act," have expanded the enforcement authority of local publicly-owned treatment works (POTWs). Through regulations and the monitoring of user facilities, POTWs, i.e., SBRSA, can ensure compliance with the facilities' effluent discharges that are regulated under not only the "Clean Water Act," but also CERCLA, RCRA, and CAA regulations.

\subsubsection{Endangered Species Act (ESA) and National Historic Preservation Act (NHPA)}

The PPPL occupies 72 acres of the Forrestal Campus of Princeton University. Previous environmental statements and the approved Environmental Assessment (EA) for the TFTR have indicated that there are no endangered species or items relating to the NHPA on-site. In addition, in the fourth quarter of 1992 and in the first quarter of 1993, the NJDEPE, Division of Parks and Forestry, Natural Heritage Data Base [Dynamac92], reported that there are no records for rare plants, animals, or natural communities on the PPPL site. 
There are records for a number of occurrences for rare species that may be on or near waterways surrounding the site. As the Natural Heritage data is based on a literature search and on individuals' observations and is not based on site-specific surveys, the data obtained from this database are not considered definitive.

\subsubsection{Executive Orders (EO) 11990 "Protection of Wetlands" and 11988. "Floodplain Management"}

The PPPL is in compliance with the EO 11990, "Protection of Wetlands." Previously, there was a question about the dirt-spoil pile from the excavations for TFTR construction, which was placed in an area (1977-78) before wetlands determinations. In 1991 DOE/PAO requested a wetlands delineation from NJDEPE. It determined that the pile lies within the wetlands buffers. In September 1992, DOE/PAO requested a determination be made by the U. S. Army Corps of Engineers (the Corps). The Corps determined that the fill material presently lies adjacent to wetlands, and that the filled area had been part of a wetlands system under the jurisdiction of the Corps. "However, since the jurisdictional area filled consisted of less than one acre of wetlands above the headwaters of any watercourse, the work is considered to have been accomplished under the nationwide permit program, specifically pursusant to 33 CFR 330 (Appendix A)(b)(26) and the appropriate conditions" [Corps92].

Further definition of the wetland boundaries was undertaken. From aerial photography using infra-red film, the presence of wetland-type vegetation was found on the north and eastern boundaries of the Laboratory property. Formal delineation of the wetland boundaries and the 50-foot transition zone (buffer area) by the NJDEPE is in progress (see Fig. 46). A site map showing the locations of the wetland boundaries and the 100 and 500 year flood plain will be completed.

A Statewide General Freshwater Wetlands Permit (GP11) application was filed with the NJDEPE, Bureau of Inland Regulation, in August 1992 for the detention-basin upgrade project. According to NJAC 7:7A, Freshwater Wetlands, the detention basin and associated drainage ditch, in which upgrades will be made, could be classified as "waters of the United States" and, therefore, "State open waters." In addition, the drainage basin and associated drainage ditch contain vegetation considered representative of freshwater wetlands species. The GP 11 designation is for the construction of stormwater outfall 
structures and associated stormwater conveyance structures such as pipes, headwalls, riprap, and other energy dissipation structures.

The PPPL is in compliance with the EO 11988, "Floodplain Management." As a result of the Tiger Team assessment, it was suggested that the PPPL HAZMAT facility may be 4 inches below the 500-year floodplain and not protected, which may be a violation if the HAZMAT facility is considered a "critical" facility under 10 CFR 1022 [CFR90]. Only one unanswered question remains here: whether the HAZMAT facility is a "critical" one in the 500-year floorplain. A determination of the exact location of the 500-year floodplain relative to PPPL facilities is in progress (see above paragraph). If the HAZMAT facility is found to be located within this floodplain, plans will be made to protect the facility against a 500-year flood.

A Stream Encroachment Permit application was filed with the NJDEPE, Bureau of Inland Regulation, in August 1992 for the detention basin upgrade project. The permit was approved and became effective in December 1992. The permit was issued to replace an existing headwall for the discharge of the detention basin.

\subsubsection{Eederal Insecticide. Fungicide, and Rodenticide Act (EIFRA)}

The use of herbicides, pesticides, and fertilizers is done by using certified subcontractors who meet all the requirements of FIFRA. The PPPL Facilities Engineering Division (FED) monitors this subcontract.

\subsubsection{National Environmental Policy Act (NEPA)}

The TFTR D-T Environmental Assessment (EA) was approved, and a "Finding of No Significant Impact" (FONSI) for the D-T Program was signed by DOE-EH on January 17, 1992. The public in the PPPL area was informed of the EA via two public meetings in March 1992 and via placing of the EA in local libraries. A Supplemental Analysis was prepared to analyze several proposed modifications to the D-T Program presented in the EA, including operation of a Tritium Purification System. DOE-EH determined on January 15, 1993, that these modifications do not constitute significant changes relevant to environmental concerns, and, therefore, no additional review under NEPA of these modifications is required. 
Work commenced in 1992 on the preparation of EA's for several proposed new projects at PPPL: construction and operation of a combined cycle Cogeneration Plant, Decontamination and Decommissioning (D\&D) of TFTR, and construction and operation of the Tokamak Physics Experiment (TPX). DOE-EH determined that an EA should be prepared for the Cogeneration Plant, and a second combined EA should be prepared to cover the TFTR D\&D and TPX projects since these are connected actions (TFTR D\&D must precede TPX construction). In 1993, plans to construct the Cogeneration Plant were terminated.

Approximately 300 PPPL activities received NEPA reviews in 1992, and the vast majority of these were determined to be Categorical Exclusions according to the NEPA regulations and guidelines of the Council on Environmental Quality (CEQ) and DOE.

\subsubsection{Resource Conservation and Recovery Act (RCRA)}

The Laboratory is in compliance with all terms and conditions required of a hazardous waste generator. PPPL is also in compliance with all requirements of the RCRA mandated Underground Storage Tank Program (see 3.1.3 above about UST leaks).

\subsubsection{Safe Drinking Water Act (SWDA)}

The PPPL receives its drinking water from the Elizabethtown Water Company. While Elizabethtown is responsible for providing safe drinking water, PPPL does test incoming water. In addition, periodic testing for potential problems within the on-site drinking water distribution system is undertaken.

On a quarterly frequency, PPPL inspects and tests the backflow prevention equipment, which prevents contamination of the potable water supply via a large cross-connection. When a representative from the Middlesex County Health Department (MCHD) is present, the system is inspected at the point where Elizabethtown Water enters $C$ site. On an annual frequency, this system is totally disassembled, inspected, and tested in the presence of both MCHD and the Elizabethtown Water Company representatives. In order to maintain an uncontaminated potable water supply, other cross-connection equipment is tested on a routine basis. 


\subsubsection{Toxic Substance Control Act (TSCA)}

The PPPL is in compliance with all terms and conditions of TSCA for the protection of human health and the environment by requiring that specific chemicals be controlled and regulations restricting use be implemented. The last PPPL polychlorinated biphenyls (PCBs) transformers were removed from the site in 1990, and only 661 PCB-regulated capacitors remain c n-site at the end of 1992.

\subsection{Current Issues and Actions}

The ongoing, environmental-compliance issue is the request for an adjudicatory hearing by DOE under the current New Jersey Pollutant Discharge and Elimination System (NJPDES) discharge to groundwater permit. The DOE protested the requirement that three monitoring wells be placed on A and B sites; these locations are off-site and are on property under Princeton University's control. The DOE and PPPL are awaiting a hearing date and have, under protest, complied with all permit-mandated activities. The DOE will request the removal of the three off-site wells from the NJPDES groundwater permit when the renewal application is submitted in 1994.

Since 1986, Princeton University has performed groundwater investigations on the James Forrestal Campus. The PPPL and DOE/PAO have been involved in similar studies on C and D sites since 1990 under the direction of NJDEPE. The Bureau of State Case Management within the NJDEPE's Division of Site Remediation reviewed the occurrence of volatile organic compounds (VOCs) in groundwater at James Forrestal Campus. In late 1991, the Bureau of State Case Management notified us that an Administrative Consent Order (ACO) would be drafted.

In early 1992, counsel for Princeton University, PPPL, and DOE met with representatives the Bureau of State Case Management to discuss the impending ACO. Following that meeting, Princeton University, PPPL, and DOE submitted comments on the generic ACO and requested that a Memorandum of Understanding (MOU) be drafted instead of an ACO. Princeton University received the draft MOU in March 1992. The MOU states that the VOC contamination present on the Forrestal Campus was contributing to the presence of VOCs in drinking-water wells in the near vicinity ( $<1 / 2$ mile from the property boundary). Comments on the MOU were sent to the NJDEPE along with a request for an extension of 
time to negotiate the conditions. The final MOU was signed by Princeton University and the NJDEPE on February 5, 1993.

Within the MOU C and D sites are separate from A and B sites and follow a different schedule due to the extended budget-approval process that DOE requires for its environmental restoration projects. Following the review of all previously submitted documents by NJDEPE, PPPL and DOE/PAO have 180 days to submit a Work Plan for conducting a Remedial Investigation/Feasibility Study (RI/FS). After review and approval of the work plan, the RI/FS will go forward. Following the approval of the RI/FS results, PPPL and DOE/PAO will begin the approved remedial action, if needed.

The PPPL was audited by a DOE Tiger Team between February 11, 1991, and March 12, 1991. PPPL had identified over 70 percent of the Tiger Team findings in PPPL's own self-assessment. There were 54 environmental findings, none of which represented situations that presented an immediate risk to public health or to the environment or that warranted an immediate cessation of operations. Of these findings, 38 were related to requirements of DOE Orders, federal or state regulations, or PPPL directives or procedures. Sixteen of the findings were related to best-management practices. In addition, there were 166 safety and health concerns and 26 management concerns. An Action Plan was finalized by PPPL in April 1991 and approved and officially released by DOE/HQ in April 1992. Of these 612 milestones, 78 percent have been completed as of May 1993.

In November 1992, DOE, Office of Fusion Energy (DOE-OFE), conducted an audit of PPPL, which assessed the progress on Tiger Team corrective action plans. The audit team concluded that the environmental program at PPPL has improved. Policy and procedures were developed or were being developed. DOE-OFE's recommendations included the following actions by PPPL: 1) review all waste management activities under one organization, 2) conduct additional NEPA training on PPPL NEPA procedures, 3) expedite a comprehensive asbestos management program, 4) complete lab-wide, waste-stream inventory survey, and 5) complete the Groundwater Protection Management Program.

The PPPL has begun with the identification of possible wastewater streams into the Stony Brook Regional Sewerage Authority (SBRSA) system. A site sanitary survey was conducted in 1992 and completed in early 1993. The survey conclusions are most reliably based on project activities performed on $C$ and $D$ sites that emit various waste streams to 
the sanitary sewer system. This sanitary sewer survey will supplement the pretreatment application submitted to SBRSA in late 1992.

In addition, PPPL has begun a limited sampling program to address the contents of various liquid effluent streams to the SBRSA. The first waste stream sampled was the outfall of the liquid effluent collection (LEC) tanks that receive drainage from the TFTR floor drains, heat, ventilation, and air conditioner (HVAC) ducts, and sumps. The program is intended to expand sampling locations in 1993. The results will be compared to both the existing and the recently proposed SBRSA rules and regulations.

Title VI, "Stratospheric Ozone Protection," of the Clean Air Act Amendments (CAAA) of 1990 mandates the recovery of substances that deplete ozone in the upper atmosphere. Those substances listed in the act include, for example, certain chlorofluorocarbons (CFCs) and halons; both of these classes of substances are used at PPPL as coolants and fire suppressants, respectively.

To reduce the amount of these ozone depleters, PPPL is:

- Looking at substitute products. Facilities Engineering Division (FED) has allocated funds for a project that will identify the impact of using alternative CFCs.

- Using recovery and recycling units. The FED currently uses three recovery units when performing maintenance on equipment that contains CFCs.

- Taking preventive measures to avoid harmful releases to the atmosphere. Maintenance and inspections are routinely performed on large source equipment. Technicians receive in-house training regarding repairing and maintenance of refrigerant systems. A disposal and recycling site has been identified for refrigerant recyling and disposal, if needed.

Title I, "Air Pollution Prevention and Control," of the Clean Air Act Amendents of 1990 mandates the control of National Air Ambient Quality Standards or NAAQS pollutants in nonattainment areas for ozone. Specifically, Middlesex County and its contiguous counties in New Jersey are designated as severe regiuns for ozone. The NJDEPE published a proposed rule, NJAC 7:27-19, "Control and Prohibition of Air Pollution from Oxides of Nitrogen $\left(\mathrm{NO}_{\mathrm{x}}\right)$," on February 16, 1993. As determined by the 1990 Air Emissions Survey, PPPL is classified as a major source of $\mathrm{NO}_{\mathrm{x}}$ due in large part to boiler emissions. As a result of this proposal, PPPL will be subject to: 1) Classification of boilers according to the proposed rule definitions; 2 ) requirements of instituting reasonably available control 
technologies (RACT), which may be no control device at all depending upon the classification of the boiler, and 3) requirements for emissions monitoring and reporting.

Title V, "Permits," of the Clean Air Act Amendents of 1990 mandates the use of operating permits, and reporting and recordkeeping requirements, which will require affected facilities to submit permit applications under state-operated, federally-enforced programs. Applications include facility-wide emission types and quantities. Title V is broad in scope, in that it incorporates many of the CAAA title requirements under one reporting mechanism.

To identify sources at PPPL that presently require operating permits or could require compliance reporting and recordkeeping in the future, an air emission survey was conducted. Various point and nonpoint sources were identified at PPPL that may be subject to reporting requirements. Two primary accomplishments will be made through the identification of process and project emission types. First, PPPL will accurately and reasonably determine its status as a major source under the air toxics and nonattainment NAAQS provisions of the CAAA. Second, PPPL will apply the survey data to the site Pollution Prevention Plan. Within the next five years, states will move toward centralizing permitting, which incorporates all media regulated activities within the pollution prevention/waste minimization arena.

\subsection{Environmental Permits}

The PPPL Environment, Safety, and Health Division maintains a status list of Environmental permits (see Table 14). A discussion of the environmental permits by the applicable statutes is listed in this table.

\subsubsection{Clean Air Act (CAA)}

The Laboratory maintains permits for four boiler vent stacks, one fuel oil storage tank vent, one diesel tank vent, two degreaser vents, one dust collector, and two emergency diesel generator exhaust stacks. Applications for additional air certificates were submitted to NJDEPE for two dust collectors, which brings the total to three dust collectors located at PPPL. All permits for these emissions are current, and all equipment under permit is operated within the permit specifications. As a result of a PPPL self-assessment before the Tiger Team, PPPL noted that some new permits may be required due to the presence of 
control equipment used in the exhaust process, not because an emission limit was triggered. The Tiger Team addressed two additional sources that should be considered for the permitting process. This air permitting program is presently being implemented. NJDEPE has publicly stated that in the next few years, site-wide permits will be issued, which would include air permits.

\subsubsection{Clean Water Act (CWA)}

The Laboratory maintains two permits under the New Jersey Pollution Discharge Elimination System (NJPDES) for discharges to surface water (NJ0023922) and groundwater (NJ0086029). The permits are for a detention basin, which discharges to Bee Brook, and for non-point source infiltration of the detention basin waters to groundwater. The NJDEPE issued a new expiration date for the groundwater discharge permit extending it from March 31, 1994, to December 31, 1994. An adjudicatory hearing was requested for the groundwater permit where several of the permit conditions are contested. In the interim, however, the permit is being maintained in full compliance including those conditions being contested in the requested hearing.

The PPPL is awaiting its renewed surface water permit from the NJDEPE. According to NJDEPE regulations, PPPL has been operating under its expired surface water permit since October 31, 1989. In March 1992 PPPL and DOE/PAO submitted an application to the NJDEPE for two new discharge points: 1) stormwater flow from the western side of $\mathrm{C}$ site that does not drain to the detention basin (DSN002A); and 2) the filter backwash discharge at the Delaware \& Raritan Canal pump house (DSN003A).

In 1992, NJDEPE inspectors audited PPPL's surface water discharges twice. The results of both inspections were acceptable or satisfactory ratings given by the NJDEPE. The first DEPE inspection of 1993 occurred on March 1, 1993. The result of that inspection was the issuance of a Notice of Violation (NOV) for total suspended solids exceedance (140 mg/l versus $50 \mathrm{mg} / \mathrm{l}$ limit) in November 1992. No penalty or fines were assessed.

During the NJDEPE's review of the TFTR D-T EA, an issue regarding the elevation of the temperature in Bee Brook was raised. The New Jersey Surface Water Quality Standards limit the temperature of the discharged water to an increase of $2.8^{\circ} \mathrm{C}\left(5.0^{\circ} \mathrm{F}\right)$ above ambient water temperature at any time. It has been noted that there are times in the winter when the delta $t(\Delta t)$ was higher than the $2.8^{\circ} \mathrm{C}$ limit. The suspected cause is ground water pumped 
to dewater various building foundations. The temperature of groundwater measures a near constant $12.8^{\circ} \mathrm{C}\left(55^{\circ} \mathrm{F}\right)$ all year round, while in the winter the surface water temperatures drop to as low as $0^{\circ} \mathrm{C}$ or $32^{\circ} \mathrm{F}$. At present, the estimated amount of groundwater pumped to dewater the TFTR and D site MG buildings is about 80,000 gallons per day. A study will be conducted during the winter of 1993-4 to more accurately determine the cause of the exceedances and to reduce the warmer water temperatures occurring during the winter.

\subsubsection{Resource Conservation and Recovery Act (RCRA)}

The PPPL maintains EPA Identification Number (NJ1960011152), which identify its status as a RCRA large quantity generator. The Laboratory is in compliance with all terms and conditions required of a "generator" status. The Laboratory's hazardous waste is generated from various cleaning processes, disposal of chemicals no longer needed, spill cleanup materials and contaminated soils, purge water from monitoring wells, and small miscellaneous waste streams. These wastes are stored at the Hazardous Materials Storage Facility for less than 90 days. Unlike RCRA, waste oil and other waste petroleum products are regulated as hazardous substances under New Jersey regulations, N.J.A.C. 7:26-1.1 et seq, "Division of Waste Management Regulations."

Mixed and radioactive waste management is the responsibility of the Health Physics Branch of ES\&H Division. Storage of these wastes are confined to the area known as the D site Boneyard or within controlled areas of the TFTR building.

The PPPL maintains, and is in compliance with, permits for four USTs in operation on the site. Note that the UST program is a part of RCRA compliance activities.

\subsubsection{Miscellaneous Permits}

The PPPL maintains permits for medical waste generation as required by the NJDEPE and for the purchase of potable water from the Elizabethtown Water Company. An agreement is in place with the New Jersey Water Authority until the year 2009 to draw water from the Delaware and Raritan canal system for cooling-water needs and fire-fighting capabilities. PPPL is in compliance with all terms and conditions of these permits. 


\subsection{January 1 - April 1. 1993 Environmental Compliance Summary}

The first quarter of calendar year 1993 has produced the following changes from the 1992 summary:

- In early 1993 NJDEPE sent Princeton University a draft Memorandum of Understanding (MOU) that recognized James Forrestal Campus as two distinct parts: 1) A and B sites under Princeton University's direction, and 2) C and D sites under DOE's direction. The MOU requires the performance of a Remedial Investigation (RI), a Feasibility Study (FS), and Remedial Action reports. Schedules for the submittal of thes? documents are specified within the MOU; most notably $A$ and $B$ sites and $C$ and $D$ sites are on separate but parallel tracks. Princeton University signed the MOU with NJDEPE in February 1993.

The commencement of MOU activities will follow NJDEPE's review of the previously submitted documents. The MOU lacks provisions for fines or penalties for failure to meet the specified schedule; however, NJDEPE reserves the right to terminate the MOU and issue a Directive or Administrative Consent Order (ACO) that has penalties and fines associated with missing defined schedules.

- In the February 5, 1993, Federal Register [FR93], the U.S. Environmental Protection Agency (EPA) published its new and/or revised list of facilities on the Federal Agency Hazardous Waste Compliance Docket. Princeton Plasma Physics Laboratory (PPPL) was listed on the docket for the first time, due to its being a hazardous waste generator and in part for having requested DOE funding through the Environmental Restoration (EM-40) program. A meeting between DOE and EPA in March 1993 resulted in the DOE's submission of additional sampling data and pertinent information about PPPL.

- In March 1993, the NJDEPE, Bureau of Water and Hazardous Waste Enforcement, arrived on-site to perform an unannounced inspection. The inspectors visited the Hazardous Materials Storage Facility and five satellite accumulation areas located throughout the site. They reviewed the training program and PPPL Waste Minimization Plan. Overall, the NJDEPE inspectors noted that PPPL complied with all the hazardous waste regulations and has a good management program in place. 
- Also in March 1993, the NJDEPE, Office of Enforcement Policy, visited PPPL to inspect the NJPDES permit program. This inspection included checking of records, particularly matching the munthly Discharge Monitoring Reports (DMR) to the analytical data, noting of any non-compliances that occurred since the last inspection and visually observing the discharge points, the detention basin, and drainage ditch. Because of the November 1992 exceedance of the total suspended solid limit (140 mg/l versus $50 \mathrm{mg} / \mathrm{l}$ limit), the inspectors prepared a Notice of Violation (NOV). However, no fine was assessed because of PPPL's status as a federal facility.

- The PPPL and DOE/PAO received the Treatment Works Approval (TWA) permit for upgrades to the detention basin in March 1993. This project includes the installation of an under drainage system and an impermeable liner in the basin, the construction of upgrades to the outfall of the basin, the re-routing of the storm drainage from the warehouse spill containment system and southeast quadrant switchyard, and the upgrading of the oil detection system at $\mathrm{C}$ site. Other state permits must be obtained before the project can begin including: 1) Stream Encroachment permit (received permit), 2) Freshwater Wetlands permit (received permit), and 3) Freehold Soil Conservation District's approval of the Soil and Sediment Control Plan (received approval). 


\subsection{ENVIRONMENTAL PROGRAM INFORMATION}

The monitoring program implementation has followed a phased approach commensurate with the potential hazards and the needs of an expanding program. Nonradioactive waterpollutant monitoring has been conducted for many years. A more extensive program was begun in 1979, which included eight surface water sampling points (four on-site and four off-site). In addition, four groundwater sites (two former drinking water wells and two wells near the TFTR liquid effluent collection tanks), along with the potable water supply, were monitored through November 1939. In November 1989, two former wells were dropped from the program, and seven new wells were added as part of the New Jersey Pollutant Discharge and Elimination System (NJPDES) permit requirements. Current NJPDES permit requirements include one detention basin discharge point for the surface water permit, two influent surface water points for the groundwater permit, and seven groundwater wells.

Monitoring for sources of potential radiological exposures is extensive. Real-time prompt gamma/neutron-environmental monitoring began on the TFTR site in 1981 to establish baselines prior to machine operation. Four monitoring stations are located at the TFTR facility boundary [formally called the exclusion zone boundary (EZB)]. Neutron monitors were added at these locations at the end of CY84. Passive tritium monitors were added in CY87. Radiological water samples are being collected at the same locations as the nonradioactive sample points (see Figs. 24, 25, and 42). Soil and biota samples are also being analyzed for tritium baselines. One off-site, baseline, tritium air monitor was added in CY89; others were sited in 1991 and began operations in February 1992.

\subsection{Assessment of Radiation Dose to the Public}

The PPPL is located in the metropolitan region between N y York City and Philadelphia. Census data indicate that approximately 16 million people live within $80 \mathrm{~km}$ (50 miles) of the site and approximately 212,000 within $16 \mathrm{~km}$ (10 miles) of PPPL. The detailed distribution of population as a function of distance is given in Tables 4-13. Because of ever-increasing, commercial growth in this area, a demographic update was planned for TFTR, but was completed as a requirement for the BPX Environmental Assessment [Be87a]. Also, a radiological assessment was completed for BPX [Mc89]. 
The overall, integrated, effective-dose equivalent from all sources (excluding natural background) to a hypothetical individual residing at the nearest business was calculated to be $0.005 \mathrm{mrem}(0.05 \mu \mathrm{Sv})$ for CY92 [St92]. This effective-dose equivalent was calculated after postulating that all the tritium produced during TFTR D-D operations and Argon-41 produced from air activation was released to the environment. Detailed person-rem calculations for the surrounding population were not performed because the value would be insignificant in comparison to the approximately $100 \mathrm{mrem}(1 \mathrm{mSv})$ each individual receives from the natural background, exclusive of radon, in New Jersey. However, scaling to calculated data was performed and indicates a value of only $4.1 \times 10^{-2}$ personrem (4.1 $\times 10^{-4}$ person-Sievert) out to $80 \mathrm{~km}$ (see Table 15).

\subsection{Assessment of Non-radioactive Pollutants}

There were no activities during CY92 that created problems involving non-radioactive pollutants. The oil spill that occurred in 1988 from underground tanks (overfill incident and leaking piping from the USTs), which presented some potential minor environmental impacts, is being addressed and is discussed below.

Polychlorinated biphenyls (PCB's) and other hazardous/toxic materials continue to be disposed of in accordance with EPA requirements. All wastes are treated, stored, or disposed of by licensed waste handlers at off-site locations. Herbicides, pesticides, and fertilizers were used in very limited quantities (see Table 29), mainly, restricted to landscape or pest elimination activities.

\subsection{Pollution Prevention and Waste Minimization}

The PPPL has a pollution prevention and waste minimization plan as required by DOE Order 5400.1 [DOE90b]. A survey was completed in June 1990 [CEE90] and indicated that PPPL had already taken many appropriate steps in warte minimization by product substitution and volume reduction. In FY91-92, a more detailed program was undertaken to further the testing and use of non-hazardous products such as "TPC Solvent®" and "Citrikleen@" in place of "Inhibisol@," acetone, and alcohol. Further investigation of possible means for source reduction will begin with waste-stream identification. Formalizing the process waste assessments through procedures and documentation and barcoding/chemical tracking were in development in 1992. 


\subsection{Regulations and Safety Criteria}

The appropriate Radiation Protection Standard for penetrating radiation was taken from DOE Order 5480.11. Specific criteria for implementing these standards are contained in PPPL Environment, Safety, and Health Directive (ESHD) 5008, Section 10, and specifically for TFTR in Technical Safety Requirements, OPR-R-23. The concentration guides, used in the analyses of surface water samples for radioactivity, were taken from DOE Order 5400.5, Chapter III. The derived concentration guides for airborne activity are taken from the same DOE Order. Tritiated water, for example, is listed as $1 \times 10^{-7} \mu \mathrm{Cl} / \mathrm{ml}$.

Air and Water Pollution Standards for nonradioactive pollutants were taken from the New Jersey Administrative Code (NJAC), Environmental Protection, 7:27-1, et seq, 7:14-1, et seq, and 7:14A-1, et seq, respectively. The appropriate regulations for PCBs and hazardous waste are found in the U.S: Code of Federal Regulations, 40 CFR 761 and 40 CFR 260-265, respectively.

\subsection{Euture Program Expansion}

\subsubsection{Meteorological}

A meteorological tower was installed in November 1983 [Mc83]. Data from this system has been used in dose calculations for the TFTR FSAR. Data were also evaluated by the former Burning Plasma Experiment (BPX) project in relation to siting the BPX at PPPL. Plans for FY93 include the installation of a real-time meteorological data output for D-T operations. Instrumentation was added at $10 \mathrm{~m}$ in 1990 to collect wind speed and direction in addition to the present instruments at 30 and $60 \mathrm{~m}$ (Figs. 9 and 10). Precipitation, now collected independent of the tower instrumentation, will be added to the readout units of the tower along with barometric pressure.

\subsubsection{Water Quality}

The initial phases of a groundwater monitoring program began in CY85. Analysis of water samples from two D site wells was added to the monitoring program in CY86 utilizing USGS data. PPPL took over the water quality program on these two wells in December 1987. Five new wells were added in response to state requirements for a groundwater discharge permit and as a result of UST spills and soil gas testing (see below). This 
expanded groundwater program will help to more fully understand our regional groundwater flow, surrounding area (off-site) groundwater contamination, and in anticipation of requirements for a new, major research device.

\subsubsection{Radioactive Effluents}

\section{A. Air. Gaseous and Particulares}

Based on collected data, a decision was made in CY84 to limit the specific air and particulate real-time monitors at the EZB to only a beta detector. Particulate air sampling has been accomplished as a best-management practice and not because of a particular source term. This sampling was discontinued because of a DOE Tiger Team finding to change from a low-volume air sampler to a high-volume air sampler.

Environmental tritium monitors tested in CY86 were deployed at the EZB in CY87. These were to be extended to off-site locations in CY88 but were delayed because of budget reductions at the end of the year. A baseline station was established off-site during 1989 at an 8-mile distance in the northwesterly direction. It was relocated to a slightly more northerly direction at approximately the same distance in 1991. Six new stations were approved by the Plainsboro Planning Board for off-site locations within $1 \mathrm{~km}$ of the TFTR exhaust stack in 1991. Actual start-up began in February 1992.

\section{B. Qff-Site Radiological Water and Biota Monitoring}

An off-site, grab sample, water-analysis program is well established. Soil and vegetation sampling is under way and will continue. Biota (strawberries, peas, etc.) are collected from the local area, and the recovered water is analyzed for tritium. The tritium content of the biota and, in general, the soil and vegetation follows the tritium content in the precipitation which can be highly variable over the year.

\subsubsection{Non-Effluents}

Air effluent standards will continue to be met by following the guidelines of the NJDEPE. Any potential toxic materials will be monitored and disposed of in accordance with applicable regulations and accepted guidelines. 


\subsection{ENVIRONMENTAL RADIOLOGICAL PROGRAM INFORMATION}

\subsection{Radiological Emissions and Doses}

\subsubsection{Penetratine Radiation}

Operation of the Princeton Beta Experiment-Modification (PBX-M) results in the production of some penetrating radiation (primarily bremsstrahlung $X$ rays and neutrons). Because the PBX-M has no roof shield, sky-shine radiation (primarily neutron) is seen at the TFTR EZB site monitoring stations. The shielding installed for the PBX-M machine has kept the total dose equivalents in occupied areas below occupational-exposure guidelines. Sky-shine radiation from the neutron production by PBX-M generally adds less than $1 \mathrm{mrem}(0.01 \mathrm{mSv})$ to the $\mathrm{D}$ site environs [St91a; St91b]. PBX-M operation was limited in 1992 and thus had no impacts to the environment.

Laboratory policy states that when occupational exposures have the potential to exceed $1,000 \mathrm{mrem} / \mathrm{y}(10 \mathrm{mSv} / \mathrm{y})$, the appropriate project manager must petition the PPPL Environment, Safety, and Health (ES\&H) Executive Board for an exemption. This value is $20 \%$ of the DOE legal limit for occupational exposure. In addition, the Laboratory applies the DOE ALARA (as low as reasonably achievable) policy to all its operations. This philosophy for control of occupational exposure means that environmental radiation levels, as a result of experimental device operation, are also very low and acceptable. To illustrate this point, a 1,000 mrem dose equivalent from direct radiation at the outer TFTR test cell wall will result in less than $10 \mathrm{mrem}(0.1 \mathrm{mSv})$ at the facility boundary.

The design objective for TFTR is to remain less than $10 \mathrm{mrem} / \mathrm{y}(0.1 \mathrm{mSv} / \mathrm{y})$ above natural background from all sources of radiation at the PPPL site boundary. The TFTR, like other tokamaks, produces bremsstrahlung radiation from the electrons striking internal hardware at the end of a pulse. These $X$ rays, in the range of 0 to $20 \mathrm{MeV}$, also produce photoneutrons.

Injection of deuterium neutral beams began at the end of CY84. With these D-D runs, the neutron fluxes have increased each year as the neutral-beam heating power has increased. In 1985, the neutron production was on the order of $5 \times 10^{16}$ for the entire year. This number increased to $2.4 \times 10^{18}$ in CY86, to $3 \times 10^{18}$ during a short run year in CY87, 
and to $9.04 \times 10^{18}$ in CY88, and because of limited operation (also more plasma transport experiments and less supershots), the number reduced to $6.4 \times 10^{18}$ in CY89. In 1990 , the neutron production was $2.3 \times 10^{19}$ [Ja90b], and in 1991 because of limited operations the value was $1.56 \times 10^{18}$ [Ja92]. In 1992, the neutron production increased to 1.53 $10^{19}$ [Ja93] due to increased TFTR operations. Additional shielding was added to the TFTR test cell walls in the middle of CY85. This added shielding has prevented the addition of any significant penetrating radiation to the environs due to TFTR operation.

The TFTR real-time site boundary monitors are Reuter-Stokes Sentri 1011 pressurized ionization chambers and ${ }^{3} \mathrm{He}$-moderated neutron detectors. The electronics in the ionization chambers were modified to allow the integration of any prompt radiation resulting from a TFTR machine pulse which may be above natural background. Data are stored and processed using the Central Instrumentation, Control, and Data Acquisition (CICADA) computer system. Four of these monitoring stations are placed at the TFTR facility boundary (see Fig. 24). In addition, eight ionization chambers of lower sensitivity, paired with neutron monitors, are located nearer the TFTR device (four outside the test cell wall, three in the basement, and one on the roof). These eight detector locations are for personnel safety and are not considered environmental detectors per se. However, data collected from them are used to help correlate the environmental measurements. Besides the moderated ${ }^{3} \mathrm{He}$ and fission neutron detectors, Bonner-type-moderated Lil(Eu) detectors were also used for monitoring neutron dose equivalents at various locations throughout the TFTR facility. Monitors are calibrated and traceable to the National Institute for Standards and Technology (NIST) formerly the National Bureau of Standards (NBS).

\subsubsection{Sanitary Sewage}

Drainage from TFTR sumps is collected in the Liquid Effluent Collection (LEC) tanks; each of three tanks has a total capacity of 15,000 gallons. Prior to release of these tanks to the sanitary sewer system, i.e., Stony Brook Regional Sewerage Authority (SBRSA), a sample is collected and analyzed for tritium concentration. All samples for 1992 showed concentrations, and therefore, the effluent, to be within the allowable limits set by New Jersey regulations $(1 \mathrm{Ci} / \mathrm{y})$ and by DOE Order 5400.5 . 


\subsubsection{Radioactive and Mixed Waste}

In CY92, low-level radioactive waste and mixed waste were stored on site, either in the D site Boneyard or within a controlled area of TFTR. One shipment of low-level radioactive waste were made to Hanford in December 1992.

\subsubsection{Special Radiation Surveys}

\section{A. EG\&G Radiation Survey (Elyover)}

In August 1980, EG\&G Idaho, Inc., under DOE contract, conducted an aerial-radiological survey of PPPL and surrounding areas [St81]. The detection system used consisted of 20 sodium iodide detectors, a multichannel analyzer, and a magnetic-tape recording system. The nominal gamma-ray, exposure-rate range observed was 8 to $10 \mathrm{mR} / \mathrm{h}$. Detected radioisotopes were consistent with normal background emitters. Since conditions have not changed at $C$ or $D$ sites since 1980 , there is no need at this time to repeat the survey.

\section{B. National Oceanic and Atmospheric Administration (NOAA)}

The Air Resources Laboratories Field Research Division (ARLFRD) of the National Oceanic and Atmospheric Administration (NOAA), Idaho Falls, Idaho, conducted atmospheric dispersion studies using tracer gases from July through September 1988. This group specializes in air quality by doing research on the physics of the lower atmosphere with emphasis on the processes contributing to atmospheric transport, dispersion, and deposition and on the development of numerical models using the results of this research. This study is being used to understand and predict human influence on the environment, especially with regard to the atmospheric transport and diffusion of toxic effluents [St89].

The Nuclear Regulatory Commission (NRC) standard-approved Gaussian models, normally used to calculate atmospheric diffusion to support radiological dose assessments, are appropriate for sites in open terrain; therefore, those models underestimate atmospheric dilution for sites like PPPL where potential sources of release are located in the midst of a complex of buildings. These buildings generate mechanical turbulence which increases atmospheric dilution and reduces dose. The field tests conducted by NOAA were performed to obtain a more realistic empirical description of actual atmospheric diffusion at PPPL in relation to TFTR. The results indicate a factor of up to approximately 16 less 
potential dose equivalents than that calculated by using NRC Gaussian models. The DOE/PAO petitioned EPA to utilize this real-time data for calculations using AIRDOS-EPA, a required code for annual NESHAPs calculations; AIRDOS-EPA is used to calculate the off-site dose equivalent (Table 15). As approved by EPA in 1991, the annual average dilution factor $(x / Q)$ derived from the NOAA tests was incorporated into the code .

\section{Lawrence Livermore National Laboratory (LLNL) Seismic Study}

The PPPL Environment, Safety, and Health Division (ESHD) initiated and provided technical direction for a contract with LLNL to perform a seismic hazard analysis for the PPPL site in 1989. This study, which was based on the latest methodology accepted by the Nuclear Regulatory Commission (NRC) for seismic analysis of Eastern U.S. nuclear power plants, indicated that the earthquake parameters applied to the TFTR project met and exceeded the current applicable DOE requirements [Sa89].

\section{DOE Environmental Measurements Laboratory (EML) Radiation Measurements}

A radiation measurement survey was accomplished by the EML in 1990. The measurements used high sensitivity instruments and confirmed ES\&H Division Health Physics measurements, which indicate that the neutron dose equivalents during operational periods in occupied areas and at the TFTR facility boundary are much less than the original conservative code calculations. The final results were published in 1991 [Ha91].

\subsubsection{Airbome Radioactivity}

Radioactivation of air and the release of tritium in measurable concentrations (by EPA accepted measurement criteria) are not expected until TFTR D-T operations. A silica-gel, environmental-tritium monitor was tested in 1986 and was placed in operation during the summer of 1987 . With experience gained by a Canadian tritium release modeling experiment and in the field at PPPL, the monitor is now using a molecular sieve in place of silica gel [Gr88b]. Based on D-D neutron production during CY92, it is estimated that a maximum of approximately $0.967 \mathrm{Ci}(36.1 \mathrm{GBq})$ of tritium could have been added to the environs outside the TFTR facility. Tritium was detected in TFTR effluent samples by a Differential Atmospheric Tritium Sampler (DATS).

The TFTR effluent sampling data was not used in determining the stack emissions for 1992. Throughout 1992 the stack emission sampling point was not considered representative of the average emissions and was not a NESHAPS approved sampling 
point. Data for 1993 will be actual data measured at the EPA NESHAPS approved monitoring point.

The 1992 tritium-dose projections assume that all of the tritium was released. Our actual experience with the absorption and adsorption of tritium in TFTR vessel-graphite tiles in 1987 indicates that some tritium produced over the last few years by D-D reactions has been retained in the tiles [St88b]. The tiles retain approximately one-third of the tritium produced during D-D reactions.

The projected dose equivalent at the nearest business from $0.967 \mathrm{Ci}$ of tritium and $1.649 \mathrm{Ci}$ of ${ }^{41} \mathrm{Ar}$ (produced by neutron activation of the test cell air during TFTR D-D experiments) was 0.017 mrem (170 nSv), based on the use of the COMPLY Code [EPA89]. When actual NOAA x/ $Q$ values are used, the calculated values are even smaller, approximately 0.0025 mrem ( $25 \mathrm{nSv}$ ) (see Table 18). An upgraded stack sampling system installed in 1992 will provide measured tritium emission for 1993 for any tritium concentrations exceeding the minimal detectable levels of the DATS. Evaluations of proper laminar flow and mixing for acceptable monitoring data have been completed and the stack sampling system has been accepted by EPA for use in complying with NESHAPS. Measurements at the TFTR fence line have shown ambient levels in the range of 1 to $6 \mathrm{pCi} / \mathrm{m}^{3}$ of elemental and oxide tritium concentrations (Figs. 26 and 28). Measurements from the off-site monitoring stations are shown in Figs. 27 and 29, "Air Tritium (HTO)" and "Air Tritium (HT)," respectively. These measurements were made with the DATS [Gr88b]. Argon-41 $\left({ }^{41} \mathrm{Ar}\right.$ ) is a potential air activation product from neutrons produced from $\mathrm{D}-\mathrm{D}$ reactions. Its maximum production in 1992 was $1.649 \mathrm{Ci}(61.6 \mathrm{GBq})$, with an estimated dose equivalent at the nearest off-site business of $0.0018 \mathrm{mrem}(18 \mathrm{nSv})$ using NOAA x/Q data (see Table 15).

In November 1983, a three-level, 60-meter tower was installed for gathering meteorological data. Data have been collected and recorded for nine years. The wind-rose data for the first six years of tower operation are shown in Figs. 3, 4, and 5. Analysis indicates that the site is dominated by neutral to moderately stable conditions, with moderately unstable to extremely unstable conditions occurring less than a few percent of the time. Average surface vinds are about $2.1 \mathrm{~m} / \mathrm{s}$ and rise to about $4.1 \mathrm{~m} / \mathrm{s}$ at $60 \mathrm{~m}$ [Ko86a]. Based on data from this tower and NOAA tracer-gas, release modeling, as well as effluent concentrations measured at the TFTR stack, real time dose projections will be 
made during the D-T operations phase to ensure compliance with applicable regulatory requirements.

\subsection{Unplanned Releases}

There were no unplanned radiological releases at PPPL in CY92.

\subsection{Environmental Monitoring}

\subsubsection{Waterbome Radioactivity}

\section{A. Surface Water}

Surface-water samples at eight locations (four on-site and four off-site) have been analyzed for tritium and photo emitters (Table 18). Five of these locations have been monitored since CY82. Downstream sampling occurs after the mixing of effluent and ambient water is complete. Locations are indicated on Figs. 24, 25, and 42.

Sample analysis has shown no unusual background radionuclides. Tritium analysis by liquid scintillation methods has shown tritium values to be less than $100 \mathrm{pCi} /$ iter (3.7 $\mathrm{Bq} /$ /iter) on all samples analyzed to dare (Figs. 33 and 34). Tritium enrichment procedures are used on some samples to provide increased sensitivities. Rain-water samples collected and analyzed ranged from less than 10 to $83.8 \mathrm{pCi} /$ iter (see Table 16 and Fig. 31), which was similar to the 1985 range of 45 to $160 \mathrm{pCi} /$ liter, the 1986 range of 40 to $140 \mathrm{pCi} /$ /iter, the 1987 range of 26 to $144 \mathrm{pCi} /$ iter, the 1988 range of 34 to $105 \mathrm{pCi} /$ iter, the 1989 range of 7 to $90 \mathrm{pCi} /$ iter, and the 1991 range of 10 to $154 \mathrm{pCi} /$ iter. The reason for these variations can be explained as follows: HT and HTO-mainly from prior world-wide, above-ground, weapons tests, - go into the stratosphere and are returned to the troposphere by turbulence. The HT slowly converts to HTO. Furthermore, the residence time in the atmosphere is on the order of years. There is a variation of HTO in rain water as the stratosphere slowly turns over, with very little exchange between the stratosphere and troposphere in the winter months [Os88]. The peak values are slowly decreasing over the years, which is consistent with the decay of tritium with no large inventories being added.

In 1988, PPPL initiated the collection of precipitation and monitored levels starting with the second quarter. While 1988 was a dry year, 1989 and 1990 were relatively wet years with over 55 inches $(140 \mathrm{~cm})$ of precipitation in 1989 and 50.3 inches $(128 \mathrm{~cm})$ of precipitation 
in 1990. In 1992 the precipitation level at PPPL was 42 inches $(107 \mathrm{~cm})$ (see Fig. 30 and Table 17 )[Ch92].

\section{B. Groundwater}

Seven existing on-site wells-W-4, W-5, D-11, and D-2 on C site (Fig. 43), and TW-1, TW-3, and TW-10 on D site-were sampled (Table 19). As a part of continuing efforts to characterize the site, a more comprehensive groundwater program was initiated in June 1985 through the USGS. This program entailed the drilling of several monitoring wells on the TFTR site in order to help profile the groundwater system. The final USGS survey report was issued in 1987 [Le87]. This report indicated a cone of depression created by the TFTR sump system (Figs. 44 and 45). The samples collected from two of the wells (TW1 and TW10 at D site) were analyzed for tritium by PPPL. The sample results were consistent with previous testing accomplished by PPPL and the USGS and indicated tritium levels less than $100 \mathrm{pCi} /$ liter (3.7 Bq/liter). These values are consistent with surface-water measurements. The results for 1992 are also less than $100 \mathrm{pCi} / \mathrm{liter}(3.7$ $\mathrm{Bq} /$ hiter), as expected; and because the pool of water tends to average out HTO added by precipitation, the large variation noted in precipitation is not seen in the groundwater.

\section{Drinking Water}

Potable water is supplied by the public utility, Elizabethtown Water Co. In April 1984, a sampling point at the input to PPPL was established (E1 location) to provide baseline data for water coming onto the site. Radiological analysis has included gamma spectroscopy and tritium-level determination. Tritium levels (Fig. 34) are similar to surface (Figs. 33 and 34) and well waters (Fig. 32) with measurements indicating less than $100 \mathrm{pCi} /$ iter (3.7 Bq/liter); also, only naturally occurring, gamma-emitting radioisotopes have been detected. Radium and radon levels have not been measured in the potable water system by PPPL.

\subsubsection{Foodstuffs}

Foodstuffs collected and analyzed in CY92 during the growing season included peas, strawberries, raspberries, tomatoes, corn, and a pumpkin. These fruits and vegetables were collected from area farmers or gardens. The variation shown in detected HTO levels of 33 to $48 \mathrm{pCi} /$ liter (see Fig. 35 and Table 21) is indicative of the variation of HTO in precipitation. 


\subsubsection{Soil. Grass, and Vegetation}

Off-site sampling locations were established in late 1985 (see Fig. 42). In 1991, some sampling points were relocated because of construction in the area in 1990 and also to be near the newly positioned air-monitoring stations. Soil and grass samples collected on-site and off-site in 1992 indicated tritium levels below $100 \mathrm{pCi} /$ /iter (3.7 Bc/liter) (see Fig. 36 and Table 20). Laboratory techniques for doing these analyses were perfected in CY84 [Gr85], and the techniques are documented in the various controlled procedures of the Radiological Environmental Monitoring Laboratory. These baselines are being established because surface soils and vegetation are among the best indicators of tritium deposition after a release [Jo74], [Mu77], [Mu82], [Mu90]. The present, measured concentrations are consistent with those of tritium in the environment. 


\subsection{ENVIRONMENTAL NON-RADIOLOGICAL PROGRAM INFORMATION}

\subsection{NJPDES Data}

\subsubsection{Surface and Storm Water}

Monthly water chemistry reports for D2 (PPPL designation) or DSN 001A (permit designation), compiled from the data of Table 27, were submitted to the state of New Jersey in 1992 in accordance with PPPL's New Jersey Pollutant Discharge Elimination System (NJPDES) permit, NJ0023922. The PPPL was well within the allowable limits for all testing parameters during CY92, except for total suspended solids (TSS) and chemical oyxgen demand (COD). In November 1992, the TSS and COD permit limits of $50 \mathrm{mg} / \mathrm{l}$ was exceeded by a value of $140 \mathrm{mg} / \mathrm{l}$ and $54 \mathrm{mg} / \mathrm{l}$, respectively. The investigation results were inconclusive to determine the source of the TSS and/or COD, which elevated the values in the November 1992 samples.

Cooling-water treatment was changed from a chromate-based corrosion inhibitor to a nonchromate inhibitor in June 1983. Water analyses downstream of the detention basin (see Table 22) have not indicated concentrations of any environmental pollutants, in general, above applicable codes, regulations, or standards with the exception of temperature during the winter months. There are instances when the downstream-station (B2) temperature was higher than $2.8^{\circ} \mathrm{C}$ or $5^{\circ} \mathrm{F}$ (NJ Surface Water Quality Criteria) above the upstream station (B1) ambient temperature. The difference in temperature, or $\Delta t$, is due to the $\Delta t$ between groundwater and surface water in the colder months of the year. The temperature of groundwater is relatively constant $\left(12.8^{\circ} \mathrm{C} / 55^{\circ} \mathrm{F}\right)$ while surface water temperatures fluctuate with air temperature. The PPPL believes that the amount of groundwater being pumped to dewater building foundations (TFTR, D site MG, and Laboratory Office Building), and not the process water from the cooling tower or boiler blowdown, is responsible for the higher temperatures observed in the winter. In the summer, the $\Delta t$ is not only less than $2.8^{\circ} \mathrm{C}$, but also at times the discharge temperature was equal to, or less than, the ambient temperature.

Storm water and process water, which includes cooling tower and boiler blowdown, are discharged into surface waters and are governed at $C$ and $D$ sites by NJPDES Permit No. NJ0023922 (effective date November 1, 1984; expiration date October 31, 1989). This permit is still in effect while NJDEPE reviews the new application request and prepares the 
new permit. All process water and most runoff water from $C$ and $D$ sites now pass through a detention basin; as part of the NJPDES Permit No NJ0086029, the detention basin inflows or influents are monitored twice each year-in May and August (see Table 26). Approximately 96.199 million gallons discharged through the detention basin in CY92. Storm-water discharge (DSN 002A) points (west side of C site), which do not run into the detention basin, are included in the surface-water renewal permit application. Upgrades to the detention basin, made in 1986, included an oil-spill detection and alarm system. As a result of minor problems following the transformer-oil leak in 1988 [St88d] and the 1988 DOE Environmental Survey, another analysis of this system determined that the best long-term, best-management practice and environmental solution is to line the detention basin and to install more reliable oil sensors. This project is funded, and completion is expected in CY93.

In March 1993, PPPL and DOE/PAO received the Treatment Works Approval (TWA) permit for the modifications to the detention basin. This projects includes the installation of an under drainage system and an impermeable liner in the basin, the construction of upgrades to the basin outfall, the re-routing of the storm drainage from the warehouse spill containment system and the southeast quadrant switchyard, and the upgrading of the oil detection system at $\mathbf{C}$ site. Other state permits obtained prior to the project's start are: 1) Stream Encroachment permit, 2) Freshwater Wetlands general permit \#11, and 3) Freehold Soil conservation District approval of the Soil and Sediment Control Plan.

\subsubsection{Groundwater Assessment}

After the application for the the groundwater permit, filed in 1986, the NJDEPE proposed the addition of two monitoring wells around the detention basin and three wells not on DOE-leased property. While DOE has requested a hearing on the off-site well aspects of the permit requirements, PPPL came into compliance with the NJPDES permit requirements; the permit, NJ0086029, was issued effective April 1, 1989, and expires on December 31, 1994. Monitoring of the off-site wells (MW-14, MW-15, and MW-16-see Fig. 42) has not shown any contaminants and, therefore, closure of the wells or turnover to Princeton University will be requested of the NJDEPE when the permit renewal application in 1994.

In 1989, low levels, parts per billion range (ppb), of volatile organic compounds (VOCs) were detected in three on-site wells. As shown in Tables 37 and 38, the presence of low 
levels of VOCs in wells, D-11, D-12, and TW-3, continued to be detected in CY92 samples. No base neutral compounds were detected in these wells at any time since sampling was begun (Table 39).

Due to the occurrences in 1989, the results of the the soil-gas survey (conducted in 1990), the underground storage tank (UST) issues, and NJPDES permit requirements, a groundwater assessment was initiated in November 1990, as directed by NJDEPE. The objective of the assessment was twofold: (1) determine the impact of the underground storage tanks on groundwater and (2) correlate the soil-gas survey results with groundwater quality of $C$ and $D$ sites.

Sixteen wells and two piezometers were installed in December 1990 and were sampled in January 1991. The results of the investigation were: 1) low-levels of semivolatile organics were detected in the wells closest to UST excavation adjacent to the Facilities Engineering Division (FED) building [MP91a], and 2) low-levels of volatile organic compounds (tetrachloroethylene, trichloroethylene, and trichloroethane) were identified in wells located on both C and D sites [MP91b].

There were two significant conclusions drawn from the groundwater quality data. The first was that the open excavation was creating a mounding effect and was driving the contamination into the groundwater (see Figs. 44 and 45). The second conclusion was that the presence of chemical contaminants in groundwater was found in only three well locations (1. MW-3 west of CAS building, 2. MW-5S, MW-6I and 6S, MW-7I and 7S near FED building, and 3. MW-9 east of RESA building) of the eighteen wells (see Figure 43), which were installed near the UST excavation and the areas identified as "hot spots" during the soil-gas survey [Ne90]. The first finding is further explained by the removal of a semi-confining layer when the tanks were originally installed and later when the surrounding soils were excavated due to the UST leak. The reports were submitted to NJDEPE in March 1991.

The NJDEPE reviewed these reports and approved the closure of the excavation pits in July 1991 with the following conditions: 1) a well couplet (one shallow and one intermediate depth, MW-8S and MW-8I) be installed immediately south of the excavation; 2) monthly water elevations be measured and contour maps drawn; and 3) quarterly monitoring samples be collected and analyzed for total petroleum hydrocarbons and annually for volatile organic compounds. The new wells were instalied in August 1991 and sampled 
two weeks after well completion; the second, third, and fourth quarter samples were collected in November 1991, February and May 1992, respectively (Table 32) [MP91g, MP91h, MP92a, and MP92c].

The western excavation was filled in CY91. The eastern excavation was filled to the level of the utility lines (about three feet below grade) in March 1992. Following the completion of repairs to the utility lines and paving over the clean fill, closure was completed in June 1993.

The NJDEPE required a second year of quarterly (fifth, sixth, seventh, and eighth quarters) monitoring for total petroleum hydrocarbons (TPH) and monthly groundwater elevation measurements as a condition for allowing the remainder of the contaminated soil to stay in the excavation (eastern excavation) [NJDEPE91c, NJDEPE92]. The TPH quarterly results (Table 32) were inconsistent; MW-6S and MW-8S samples were $1.8 \mathrm{mg} / \mathrm{l}$ and $1.2 \mathrm{mg} / \mathrm{l}$, respectively in November 1992 [RES93a].

Groundwater samples were analyzed for volatile organic compounds (VOCs) in August 1992 (Table 33) [RES92a]. The VOCs-chloroform, trichloroethane, trichloroethene, tetrachloroethene, and 1,2-dichloroethene-were detected in wells MW-6S, MW-7S, and MW-8S. In 1991, only MW-8S and MW-81 samples were analyzed for VOCs; it is interesting to note that during the 1991 VOC sampling, VOCs were detected in MW-8I (total VOCs $179 \mu \mathrm{g} /$ ) and not in MW-8S [MP91g]. No explanation for this shift of VOCs from MW-8I in 1991 to MW-8S in 1992 is available; however, the results from the 1993 sampling may provide an answer.

The mounding effect of the open excavation and/or the porous clean fill materials can be observed graphically in Fig. 38 (see Table 30 for elevations). The shallow wells adjacent to the excavation area exhibit similar groundwater elevations, except well MW-5S. Well MW-5S, which is located farther away from the excavation, would not be influenced by mounding to the same extent as those wells closer to the excavation. In fact, once groundwater elevations measurements are made following paving, the shallow wells should look more similar to MW-5S.

Two other well clusters (Table 31) are shown in Figs. 37 and 39. Wells UST-1, P-1, and MW-2 are all located west of the excavation; groundwater elevations and chemical data for these three wells are the same, i.e., no detection of TPH or VOCs and the groundwater 
elevations are nearly identical. The intermediate wells-MW-5I, MW-6I, MW-7I, and MW-8I-also exhibit similar results for groundwater elevation and chemical analyses [RES92a, RES93a, and RES93b].

A third year (FY94) of groundwater monitoring of UST wells continues because of the periodic appearance of petroleum hydrocarbons in some of these wells. Since paving of the area was completed in June 1993, the groundwater elevation results have shown that mounding due to surface infiltration has declined. Should petroleum hydrocarbons be consistently below the detection limit $(<1.0 \mathrm{ppm})$, the quarterly sampling frequency required by the NJDEPE may be reduced.

In correspondence with DOE [NJDEPE90], the NJDEPE required PPPL to submit a usage survey of solvents and other hazardous substances. In September 1991, PPPL and DOE/PAO submitted a report, "Solvent and Hazardous Constituent Usage Survey," [MP91f] to NJDEPE. The survey showed that there are petroleum hydrocarbons and solvents present in most buildings at PPPL. The solvent 1,1,1-trichloroethane (TCA) is widely used throughout the Laboratory; however, substitute solvents/detergents are being made available and used wherever suitable.

In 1991 an investigation of the groundwater in the vicinity of the $C$ site Motor Generator (MG) building 1,000-gallon, diesel-oil tank was conducted; the tank, which supplies the emergency diesel generator, had a lose fitting that leaked and subsequently was repaired. No petroleum hydrocarbons (PHC) were detected in the groundwater. The Discharge Investigation and Corrective Action Report (DICAR) [MP91c] was submitted to the NJDEPE in April 1991. No further action is planned until the removal of the tank occurs, at which time more soil removal may be required, based on the levels of PHC detected in the soil borings.

In March 1991, the impact of the detention basin on groundwater was investigated, primarily by recording the levels of water in the detention basin and the water levels in wells D-11, D-12, and MW-9 (control well). The results of this study [MP91d] revealed that the basin does not appear to discharge to the surrounding groundwater, but rather the groundwater is discharging to the basin at all times except when the basin is at the maximum level. Therefore, a mounding effect was not observed, and the detention basin should not be contributing any contamination to the groundwater. 
In late 1990, the RESA building hydraulic-oil spill was reported to the NJDEPE. A new, groundwater-monitoring well adjacent to the spill was required by NJDEPE. Well MW-13 was installed in April 1991, and samples were collected in May and June 1991. Indications were that no residual of the hydraulic oil is present in the groundwater; however, relatively high concentrations of PCE were detected at $200 \mathrm{mg} / \mathrm{l}$ and $140 \mathrm{mg} /$. A report was prepared and submitted to NJDEPE in October 1991 [MP91e]. This well, MW-13, is incorporated into the site regional hydrogeological study, which is part of the MOU documentation.

Regarding the volatile organic contaminants detected in the groundwater, the case was referred to the NJDEPE Bureau of State Case Management. The significance of this referral to the Bureau of State Case Management is that the NJDEPE could require DOE/PAO and PPPL to conduct groundwater remediation actions directed through an agreement between Princeton University and NJDEPE. The outcome of discussions between NJDEPE, Princeton University, PPPL, and DOE was the signing of the Memorandum of Understanding (MOU) by NJDEPE and Princeton University; the MOU directs Princeton University to investigate the site conditions at the James Forrestal Campus, A , B, C, anid D sites.

\subsection{Qther Non-Radiological Data}

\subsubsection{Other Emissions Monitoring Data}

\section{A. Airbome Effluents [Ki91]}

The PPPL has New Jersey Department of Environmental Protection and Energy (NJDEPE) air permits for its four $C$ site boilers and one fuel tank vent (a 15,000-gallon, diesel tank vent-E\#8). The five permit certificates, numbered 061295 through 061299 , were renewed in 1987 and expired on March 31, 1992; applications have been submitted for the renewal of these permits. Five additional air permits include a vapor degreaser located in the TFTR Hot Cell, a vapor degreaser located in the Field Coil Power Conversion (FCPC) building, the TFTR emergency generator diesel engine, the $\mathrm{C}$ site emergency generator diesel engine, and a dust collector located at the CAS building carpenter shop (Table 14).

Through the Air Emissions Survey, additional sources, point and fugitive emission sources, were identified. Air emission sources at PPPL were grouped into three distinct 
areas that include: 1) point source emission, 2) fugitive emissions during project activities, and 3) fugitive emissions from standard operations of the facility [Wi93a].

For purposes of the survey, point sources include those areas where an activity occurs, which produce air emissions from a specific source to the outside ambient air. These areas include laboratory fume hoods, welding hoods, dust collectors, photo and copier hoods, stationary gas and diesel generators, boilers, degreaser vents, cooling towers, and fuel storage vents.

Fugitive emissions during project activities include areas where an air-emission producing activity is occurring, which causes emissions to the inside or outside of a facility building and that is not contained within an emission-capture device, such as a stack or vent to the outside ambient air. These fugitive emission sources include vacuum pumps, photocopiers, ovens, welding fumes, grinding and soldering activities, general area exhaust fans, uncontrolled refrigerant leaks, unvented ultrasonic degreaser baths, painting. and use of degreasers and cleaners. Degreasers may include halogenated volatile organic compounds. Cleaners may include or contain alcohols, aldehydes, and ketones.

Fugitive emissions from everyday operations of the facility include those fugitive emissions that would be produced and emitted outside to the ambient air routinely at the facility and that occur due to widespread activities from many point sources. These emissions include government and personal vehicle operation, outdoor fertilizer, herbicide, and/or pesticide application, refueling of government vehicles, emergency vehicle test runs, and refueling of diesel, gasoline, and any other compressed gases used and stored on site.

Measurements of actual boiler emissions are not required. Emissions were initially calculated using formulas supplied by the NJDEPE [Ki88]. These formulas are based solely on the percent sulfur and the number of gallons of oil burned per hour in each boiler. PPPL utilizes an ENERAC POCKET 50 combustion-efficiency analyzer to indicate the boiler efficiency, oxygen content, flue-gas temperature, and carbon-dioxide content of the stack gas for both oil and natural-gas fuels. This information is recorded and entered into a $\log$ book by the boiler operators. This is done to optimize boiler efficiency and to reduce fuel costs in accordance with DOE Order 4330.2D [DOE88b].

The Air Emission Survey for 1991 was completed and returned to NJDEPE. Under the definition of a major facility (one which emits $>25$ tons of nitrous oxides annually), PPPL 
emits more than a total of 25 tons of nitrous oxides $\left(\mathrm{NO}_{\mathrm{x}}\right)$ per year from the four boilers; on a per boiler basis, each unit emits less than 25 tons of $\mathrm{NO}_{x}$ annually.

\section{B. Drinking Water}

Potable water is supplied by the public utility, Elizabethtown Water Co. The PPPL used approximately 28.8 million gallons in $\mathrm{CY} 92$ [ $\mathrm{Kr} 93$ ]. This is a significant reduction from years prior to 1987 because of the changeover to Delaware \& Raritan (D\&R) Canal water for the cooling-water systems. Water-quality analysis at the input to PPPL was initiated in CY84 to measure nonradioactive pollutants (Table 24, E1 location), as well as to measure potential radioactive pollutants exclusive of radium or radon.

\section{Process (nonpotable) Water}

Nonpotable water is pumped by PPPL from the D\&R Canal as authorized by a permit agreement with the New Jersey Water Supply Authority. The present agreement gives PPPL the right to draw up to one million gallons of water per day for process and firefighting purposes for the period beginning July 1984 and ending on June 30, 2009. Renewal is expected at the end of the present contract. Filtration to remove suspended solids, chlorination, and corrosion inhibitor are the primary water treatment. The filterbackwash discharge (DSN 003A) is included as a separate discharge point in the surfacewater permit renewal application. In 1986, a multimedia sand filter with crushed carbon was installed to allow the source of the $\mathrm{D}$ site cooling tower make-up water to be changed from potable water to process-water supply. The PPPL used approximately 67.9 million gallons of canal water during CY92 [ $\mathrm{Kr} 93$ ]. The sampling point $(\mathrm{C} 1)$ was established to provide baseline data for process water coming on-site. Table 23 indicates results of water quality analysis at the canal.

\section{Surface Water}

Surface water is monitored for potential nonradioactive pollutants both on-site and at surface-water discharge pathways (upstream and downstream) off-site. The additional sampling locations-Bee Brook, Ditch \#5, Delaware \& Raritan Canal, Elizabethtown Water Company, Millstone River, and Plainsboro sampling points (See Figs. 24, 25, and 42 , and Tables $22,23,24$, and 25)-are not required by regulations, but are a part of a PPPL best-management practice. 


\section{E. SPCC}

An updated Spill Prevention Control and Countermeasures (SPCC) Plan was prepared by an environmental consultant in January 1985; this plan underwent extensive review and revision in CY91 [MP92b]. The final plan was completed in May 1992; it is incorporated as a supplement to the PPPL Emergency Preparedness Plan. This last update was delayed until after the EPA issued the Final Regulations for Underground Storage Tanks (UST). PPPL will install five, new above-ground tanks to replace all of its underground tanks by CY94.

\section{F. Sanitary Sewage}

Sanitary sewage is discharged to the publicly-owned treatment works operated by South Brunswick Township at the Stony Brook Regional Sewerage Authority (SBRSA). During 1992, PPPL's on-site metering devices were malfunctioning. As a result, an agreement is currently in effect among PPPL, South Brunswick Sewerage Authority, and the Township of Plainsboro, which determines the approximate flow rates from PPPL based on historical data. The estimated volume has been adjusted for the interconnections with Forrestal Campus A and B sites and a private business. In 1991, flow rates as measured by the PPPL sanitary-sewage metering station indicated a total volume discharge of approximately 15.6 million gallons. For CY 92, PPPL estimates a total discharge of 19.8 million gallons of sanitary sewage to the South Brunswick sewerage treatment system [Kr93].

In the past, sampling of PPPL discharges, performed by the publicly-owned treatment works, had determined that pretreatment is unnecessary. Therefore, PPPL is in compliance with the EPA Pretreatment Regulation, 40 CFR Part 403. However, SBRSA published proposed new service rules in February 1993. These rules will require new sampling be performed, reported, and managed through site permits. When these regulations are promulgated, PPPL will be subject to these monitoring and reporting requirements.

During the DOE Tiger Team assessment, the lack of a treatment works approval (TWA) by NJDEPE for the PPPL Calibration and Service Laboratory building (CASL) sewageholding tank was cited by the team. The CASL TWA was submitted to the NJDEPE, Bureau of Industrial Discharge Permits, and to SBRSA in June 1992. In addition, Plainsboro Township, Plainsboro Township Health Department, and the South Brunswick Township were sent the CASL TWA in September 1992. 
Subsequently, PPPL found that no TWA was submitted for the TFTR liquid effluent collection (LECs) tanks . In October 1992, the TWA for the LEC tanks was submitted to the same agencies as the CASL TWA. However, PPPL was informed by the NJDEPE that a TWA was not required for the TWA approval due to an exemption of the LEC tanks, based on the date of their installation. Wastewater-collection tank systems installed prior to 1988 are not regulated under the TWA program. This "grandfathering" status was a policy statement by the NJDEPE and is not included in the regulations. The NJDEPE did advise PPPL that a significant indirect user (SIU) review would be required by the publiclyowned treatment works agency, i.e., SBRSA.

A third TWA for the upgrades to the detention basin (a new project) was filed with NJDEPE in CY92. The TWA permit was approved and became effective in February 1993, Permit number 92-7082-4N.

\section{G. Herbicides, Fertilizer, and Pesticides [Ra92]}

During CY92, the use of herbicides, pesticides, and fertilizers was managed by PPPL's Facilities Engineering Division (FED) utilizing an outside contractor. These materials are applied in accordance with state and federal regulations. Herbicides are applied by a certified applicator. Table 29 lists the quantities applied during CY92. No herbicides, pesticides, or fertilizers are stored on site; therefore, no disposal of these types of regulated chemicals is required by PPPL.

\section{H. Polychlorinated Biphenyls (PCBs)}

Beginning in CY82, PPPL started a program to dispose of PCB-containing capacitors, transformers, and other similarly contaminated items. During the early phases of the program, all stored items in a GSA (General Services Administration) Warehouse in Belle Mead, New Jersey, were discarded through approved disposal contractors. Remaining PCB items were labeled, as required by EPA regulations, and an inventory, inspection, and status report program was initiated. At the beginning of CY84, PPPL still had 15 PCB transformers and 6,005 large capacitors containing PCBs. In CY84, 375 large and 54 small PCB capacitors were disposed of, as well as the oil and containers of two transformers. In 1985, an additional 1,330 large capacitors and 22 small capacitors were removed properly from the site. In 1986, a few small capacitors but no transformers were discarded. In 1987, two transformers containing 700 gallons of PCB fluid were disposed. In addition, 1,145 gallons of less than 500 ppm PCB fluid were generated from reworked and reclassification of six PCB transformers to non-PCB transformers, and 391 capacitors 
were disposed. In 1988, 1,696 capacitors and four small transformers were removed. In 1989, 273 capacitors were disposed while an additional 1,108 were removed from service. Eleven transformers were disposed along with one contaminated transformer containing 113 gallons of PCB fluid (186 ppm). In 1990, the remaining PCB transformers were disposed, leaving only one contaminated transformer $(>50 \mathrm{ppm})$ on-site. This transformer became a noncontaminated transformer in 1991. At the end of 1992, PPPL was left with only 661 large regulated capacitors. PCB capacitors are being disposed as they are taken out of service. Disposal records are listed in the Annual Hazardous Waste Generators Report [La93].

In July 1991, PPPL initiated a program to remove old fluorescent light fixtures and to replace them with energy efficient fixtures. Prior to 1979, nearly all light ballasts were made with capacitors which contained PCBs. Those light ballasts which were not marked "non-PCB" were assumed to be PCB and were placed in drums. By the end of the program in March 1992, 15 drums containing these ballasts were filled and were sent to a licensed PCB incinerator for disposal.

\section{Hazardous Wastes}

Responsibility for this program rests with the PPPL Hazardous Material Coordinator under the supervision of the Head, Office of the Environmental Restoration/Waste Management Administration (ER/WM). A facility (HAZMAT building) was set up in CY82 for temporary storage of hazardous materials. A new area was built in 1986. This facility has concrete floors with containment walls, fire alarms, security surveillance, fire extinguishers, an eye-wash station, an emergency shower, and telephones. Improvements to the facility, following experience gained from operational needs, were made in CY88. A concern in 1990 was the flaking of the epoxy sealant used throughout the entire building. In 1991, the flooring in the HAZMAT building was removed and replaced with a new coating of epoxy sealant. A question raised during the DOE Tiger Team assessment indicates a resolution is needed on some areas of the facility being within the 500-year flood plain when the definition of "critical action" per 10 CFR 1022 is applied [CFR90]. This issue will be addressed by using the new site plan, which was finished in CY93, to determine the location of the facility in relation to the 500 -year flood plain. A request has been made to DOE EM to fund upgrades to the facility in FY94.

The Hazardous Waste Generator Annual Report (EPA ID number NJ1960011152) has been submitted for 1992 in accordance with EPA requirements [La93]. During 1992, 
44,709 pounds of solid materials and 11,433 gallons of liquid waste were disposed at EPA-certified treatment, storage, and disposal facilities. These totals include approximately 4,800 gallons of oil-contaminated waste generated from a hydraulic oil incident [Fi93b].

\section{J. U.S. Geological Survey Study}

A groundwater study by the U.S. Geological Survey (USGS) began in 1985 and was completed in 1987 [Le87]. While this special study was predicated on a spill of tritium from the liquid effluent collection (LECs) tanks, it more appropriately addresses the general groundwater quality and flow patterns in the region near the TFTR facility. Figure 40 shows the potentiometric surface of the bedrock aquifer from this report. The report also indicated that the sumps under the TFTR complex create a cone of depression (Fig. 41). These data are being used in conjunction with the present groundwater studies. In 1991, USGS continued to record groundwater elevations from two monitoring wells located north of TFTR. The USGS also presented PPPL some data developed in an unrelated study on naturally occurring radioactivity in the ground. Uranium-enriched rocks can be a source of radioactivity in groundwater [Sz87, Za87].

\section{K. DOE/HO Environmental Survey}

A comprehensive environmental survey was conducted by DOE/HQ utilizing outside subcontractors during the month of June 1988. This survey was part of a DOE program which looked at $\mathbf{4 5}$ of its facilities. No significant environmental impact findings were noted at PPPL during this survey. A plan of action for findings was forwarded to DOE, and except for long-lead time items, the findings have been closed out. Soil sampling for petroleum hydrocarbons from former spills and for chromium in soils from previous use in cooling towers was accomplished in November 1988 [DOE88a]. Data from this sampling effort have not shown any significant contamination requiring any follow-up action by PPPL.

\section{DOE/CH Audit/Appraisal}

Normally during the month of August, DOE/CH conducts its annual audit/appraisal of PPPL Environment, Safety, and Health (ES\&H) and Environmental Restoration/Waste Management (ER/WM) Divisions. The audit/appraisal investigates the following areas: Environmentai Protection, Quality Assurance, Industrial Hygiene, Safety Analysis Review System, and Health Physics. In 1992, an appraisal that included environmental protection was not conducted, owing that personnel/responsibilities were in transition. 


\section{Woodlands and Wetlands}

The Princeton Forrestal Center's Forest Management Plan, prepared in July 1990, was approved by the NJDEPE, Division of Parks and Forestry [For90]. The Princeton Forrestal Center includes a total of 233 acres for site development and 144 acres of woodlands, including PPPL's site. The purpose of the plan, which brings the property into compliance with a recent amendment to the Farmland Assessment Act of 1964, is to improve the productivity of the woodlot, to sustain the level of activity and incomes required for maintenance of farmland status, to maintain and enhance wildlife habitat, to preserve the aesthetic quality of the woodlot, and to protect soil quality.

The management plan period extends from the year 1990 to 2000 . The 144 acres of woodland ranges from recently mature old fields to overmature hardwood timber. The Middlesex County Soil Survey displays the relevant soil types representative of the woodlands acreage. The Nixon loams, Nixon Variant loam, and the Downer sandy loam are representative of well-drained sites. These soils support red, white, and black oaks, poplar, and ash. The fourth soil type includes the Fallsington Variant loam that is representative of poorly drained sites. As a result, wet-site trees species such as sweetgum, red maple, blackgum, and pin and swamp white oaks are represented.

The PPPL is surrounded by wetlands on the south, east, and north of C and D sites (Fig. 46). In 1992, a wetlands delineation was performed in these areas. The 50-feet transition area was delineated as well by Normandeau, a subtier contractor [Nor92]. A total area of approximately 11 areas was identified to be wetlands. A 5.23 acre area north of $C$ and D sites, a 0.07 acre area east of D site, a 3.43 acre area east of the detention basin, and a 2.44 acre area south of $C$ and $D$ sites were identified to be wetlands. This delineation is preliminary until a Letter of Interpretation (LOI) is issued by the NJDEPE.

\subsubsection{Continuous Release Reporting}

Under CERCLA's reporting requirement for the release of a listed hazardous substance in quantities equal to or greater than its reportable quantity, the National Response Center is notified and the facility is required to report annually to EPA. Because PPPL has not released any CERCLA hazardous substances, no "Continous Release Reports" have been filed with EPA. 


\subsubsection{Environmental Occurrences}

Nineteen releases were reported to the NJDEPE Hotline, and confirmation reports submitted in CY92 (Table 28). In accordance with reporting requirements, notifications were made to the NJDEPE, because these release events posed a potential threat to the environment. No reports to the National Response Center (NRC) were made since there were no releases which exceeded the reportable quantities (RQ) for any listed substance.

Of the three reported releases, all three incidents involved the release of two (2) gallons or less of a petroleum product (mineral oil, hydraulic fluid, and \#6 oil) onto an unpaved surface [Fi93a, Fi93b, Fi93c]. Each incident was cleaned up immediately upon being reported.

This number of reported occurrences has been greatly reduced compared to the 19 incidents reported in CY91. The cause for the reduction is the guidance issued by NJDEPE in November 1991 [NJDEPE91a]; the guidance states "Leaks, which are releases into secondary containment or to a diversion system or releases onto a surface from which they are cleaned up and removed before they reach the lands or waters of the state, are not required to be reported." Many of the incidents reported in CY91 were leaks released onto a surface from which they were cleaned up and removed.

\subsubsection{SARA Title III Reporting Requirements}

The NJDEPE administers the SARA Title III reporting for EPA Region II. The modified Tier I form includes SARA Title III and NJDEPE specific reporting requirements. PPPL submitted the SARA Title III report to NJDEPE in February 1993. No significant changes from the previous year were noted.

The report included information about twelve compounds used at PPPL. Of the twelve, five compounds are in their gaseous form and are classified as sudden releases of pressure hazards, and two are also acute health hazards. There are eight liquid compounds; nitrogen is used in both gaseous and liquid forms. Fuel oil, gasoline, and petroleum oil are flammables; bromotrifluoromethane, dichlorodifluoromethane, and sulfuric acid are acute health hazards; sulfuric acid is reactive. PCB's and gasoline are listed as chronic health hazards. 


\subsection{GROUNDWATER PROTECTION}

As part of our NJPDES permit, groundwater sampling was begun at the end of 1989 on seven additional wells (D-11, D-12, MW-14, MW-15, MW-16, TW-2, and TW-3). The data are indicated in Tables 34 through 39. Until January 1992, the permit number was the same number as the surface water, NJ0023922, with an effective date of May 1, 1989. In 1991 the permit number was changed to NJ0086029, and in 1992 the expiration date changed from April 30, 1994, to December 31, 1994.

Other monitoring data included base neutrals and volatile organics (Tables 37, 38, and 39) and general chemistry for the detention basin inflows (Table 26) and monitoring wells (Tables 34, 35, and 36). During May and August 1992 sampling, the solvent, tetrachloroethene (PCE), was detected in wells D-11, D-12, and TW-3. During May and August 1992 sampling, trichloroethene (TCE) and 1,1,1-trichloroethane (TCA) exhibited non-detected values for these wells and in the $\mathrm{D}$ site inflow compared to being detected in the previous the August 1991 sampling.

Groundwater assessment initiated in 1990 was completed early in 1991. To further characterize groundwater quality, the direction of flow, and the source of contamination, future investigations are anticipated for the end of CY93. The delay is due in part to a study, CERCLA Inventory of Past Hazardous Releases, which was completed in CY93; and funding for additional work is not expected until fiscal year (FY) 1993. 


\subsection{QUALITY ASSURANCE}

Analysis of environmental samples for radioactivity was accomplished in-house by the Radiological Environmental Monitoring Laboratory (REML). The REML procedures follow the EPA HASL-300 Manual [Vo82] or other nationally recognized standards. Approved analytical techniques are documented in the REML procedures [REML90]. PPPL participates in the EPA (Las Vegas) program. These programs provide blind samples for analysis and subsequent comparison to values obtained by other participants, as well as to known values. Results are shown in Table 40.

In CY84, PPPL initiated a program to have its radiation-counting laboratory certified by the state of New Jersey through the EPA Quality Assurance (QA) program. In March 1986, the REML facilities and procedures were reviewed and inspected by EPA/Las Vegas and the NJDEPE. The laboratory was certified for tritium analysis in urine and water and recertified in these areas in 1988, 1989,1990, and 1991. While the certification was expected to have been extended to gamma spectroscopy in 1990, as all of the blind samples to date have been within expected detection limits (see Table 40), an official site visit has not yet been made by NJDEPE to authorize this certification.

In 1991, PPPL developed specific procedures, EN-OP-01 and EN-OP-02, "Surface Water Sampling Procedure" and "Ground Water Sampling Procedures," respectively, which provide detailed descriptions of all the NJPDES permit-required sampling and analytical methods for the collection of samples, the analyses of these samples, and the quality assurance/quality control requirements. Following these procedures are a requirement that all subcontractor laboratories and/or PPPL employees must meet. Chain-of-custody forms are required for all samples; holding times are closely checked to ensure that the analysis was performed within the established holding time and that the data is valid. Field blanks are required for all ground water sampling, and trip blanks are required for all volatile organic compound analyses.

Split and duplicate samples are analyzed by the subcontractor laboratory, Northeastern Analytical Corporation. The results of these samples are shown in Table 41. This laboratory participates in a state of New Jersey QA program and has quality assurance plans [NAC90]. 


\subsection{ACKNOWLEDGEMENTS}

The PPPL ES\&H Health Physics for the data for radiation analysis, in-house radiochemical analyses, and the meteorological data, instrument installation, and calibration.

The PPPL Facility Engineering Division for all water-utilization information and the fertilizer, herbicide, and pesticide data.

The PPPL Engineering Division for the Wind roses and the neutron generation data.

The PPPL ES\&H Environment and Health Branch for the NESHAPs calculations and emissions data and non-radiological air emissions, surface, and groundwater data.

The PPPL ER/WM Division for the hazardous-waste disposal and PCB information.

The PPPL Photographic Department for the numerous figure reproductions.

The PPPL ES\&H Support Staff for their proof-reading and editorial comments.

This work is supported by the U.S. Department of Energy Contract No. DE-AC02$76 \mathrm{CHO} 3073$. 


\subsection{REFERENCES}

AP42 USEPA, September 1985, "Compilation of Air Pollutant Emission Factors: Stationary Point and Area Sources," Part 1 of 2, Fourth Edition, PB86-124906.

Be87a Bentz, L. K., and Bender, D. S., 1987, "Population Projections, 0-50 Mile Radius from the CIT Facility: Supplementary Documentation for an Environmental Assessment for the CIT at PPPL,"EGG-EP-7751, INEL, Idaho Falls, Idaho.

Be87b Bentz, L. K., and Bender, D. S., 1987, "Socioeconomic Information, Plainsboro Area, New Jersey: Supplementary Documentation for an Environmental Assessment for the CIT at PPPL," EGG-EP-7752, INEL, Idaho Falls, Idaho.

CEE90 Corporate Environmental Engineering, June 1990, "Waste Minimization Study and Industrial Products Review," Corporate Environmental Engineering, Inc., Princeton, NJ, A Report to PPPL under Subcontract No. S-03225-G.

CFR90 Title 10, Code of Federal Regulations, Part 1022, "Compliance with Floodplain/Wetlands Environmental Review Requirements."

Ch93 Chase, K., 1/4/93, "Annual Precipitation Report (1992)," Princeton Plasma Physics Laboratory, Internal Memo.

Co81 Corley, J. P. et al., 1982, A Guide for: Environmental Radiological Surveillance at U.S. Department of Energy Installations DOE/EP-023, (National Technical Information Service).

Corps92 C. Mallery (Corps) to A. Wrigley (DOE/PAO), Department of the Army, New York District, Corps of Engineers, Case No. 92-186, "Princeton Plasma Physics Laboratory Action ID 199214520."

DOE88a Environmental Survey Sampling and Analysis Plan, November 1988, PPPL S\&A Plan, INEL/EG\&G report to DOE.

DOE88b DOE Order 4330.2C, 3/23/88, In-House Energy Management.

DOE89 DOE Order 5480.11, 7/20/89, Radiation Protection for Occupational Workers.

DOE90a DOE Order 5400.5, 6/5/90, Radiation Protection of the Public and the Environment.

DOE90b DOE Order 5400.1, 6/29/90, General Environmental Protection Program.

Dynamac92 Dynamac Corporation, August 1993, "CERCLA Inventory Report."

En87 Envirosphere Company, 1987, "Ecological Survey of Compact Ignition Tokamak Site and Surroundings at Princeton University's Forrestal Campus," Envirosphere Company, Division of Ebasco, Report to INEL for the CIT.

EPA89 US Environmental Protection Agency, October 1989, Users Guide for the Comply Code, EPA 520/1-89-003. 
EPA91 US Envircimental Protection Agency, 3/13/91, Bruce Sprague, Chief, Response and Prevention Branch, to Joseph Stencel, PPPL ES\&H Deputy Division Head, letter.

Fi92a Finley, V., April 1992, "Capacitor Failure Incident, ER92-01."

Fi92b Finley, V., April 1992, "Hydraulic Oil Incident, ER92-02."

Fi92c Finley, V., September 1992, "Fuel Oil Release Incident, ER92-03."

F184 Fleming, R. B., et al., February 1984, Safety Assessment Document for the Brinceton Beta Experiment. Princeton Plasma Physics Laboratory (unpublished).

For90 Forest Management services, July 1990,. "A Forest Management Plan for the Princeton Forrestal Center."

FR93 Federal Register, Volume 58, No. 23, February 5, 1993, "Federal Agency Hazardous Waste Compliance Docket."

FSAR82 Final Safety Analysis Report. Tokamak Fusion Test Reactor Facilities, Princeton Plasmas Physics Laboratory, 1982.

Gr85 Griesbach, O. A., and Stencel, J. R., "An Environmental Monitoring Program for a Fusion Test Reactor," Proceedings of the 18th Midyear Topical Meeting of the Health Physics Society, Colorado Springs, CO, Jan. 6-10, 1985, pp.227-233.

Gr88a Griesbach, O. A., and Stencel, J. R., "Operational Experience with the DATS Sampler During the Canadian Tritium Modeling Experiment, "Fusion Technology, 14, Part 2A, Sept. 1988, 1199-1202.

Gr88b Griesbach, O. A., and Stencel, J. R., "The PPPL Differential Atmospheric Tritium Sampler (DATS)," Proceedir.gs of the 22nd Midyear Topical Meeting of the Health Physics Society, San Antonio, TX, Dec.4-8, 1988, pp. 374-380.

Ha91 Hajnal, F., et al.,. International Environmental Measurements Laboratory Report, "Measurements of Neutron Radiation Fields at The Princeton Tokamak Fusion Test Reactor (TFTR)," April 1991.

Ja92 Jassby, D., February 1992, "TFTR Neutron Production for 1991-1992," PPPL Internal Memo.

Ja93 Jassby, D., February 1993, "TFTR Neutron Production for 1992-1993," PPPL Internal Memo.

Jo74 Jordan, C. F., Stewart, M., and Kline, J., 1974, "Tritium Movement in Soils: The Importance of Exchange and High Initial Dispersion," Health Physics. 27, pp. 37-43.

Ki88 Kircher, C., 3/14/88, "Calculations for Boiler Emissions," Princeton Plasma Physics Laboratory, Internal Memo.

Kr93 Kress, R., 3/18/93, "Water Utilization," personal communication. 
K086a Kolibal, J., et al, 1986, Meteorological Data Summaries for the TETR from January 1984 to December 1985, Princeton Plasma Physics Laboratory Report No. PPPL-2369.

Ko86b Kolibal, J., 3/24/86, "Sectorized Agricultural and Population Data Estimates," EAD-1442, Plasma Physics Laboratory Internal Memo.

La93 Larson, S. B., 3/93, “1992 Hazardous Waste Report Detailing Princeton Plasma Physics Laboratory's Hazardous Waste Activity for Calendar Year 1992."

Le87 Lewis, J. C. and Spitz, F. J., 1987, "Hydrogeology, Ground-Water Quality, and The Possible Effects of a Hypothetical Radioactive-Water Spill, Plainsboro Township, New Jersey," U.S. Geological Survey Water-Resources Investigations Report 87-4092, West Trenton, NJ.

Mc83 McCarthy, E. F., and Errera, L. J., 8/15/83, Einal Monitoring Plan: Tokamak Fusion Test Reactor Meteorological Monitoring Program. TRC Consultants, Inc., 800 Connecticut Blvd., East Hartford, CT 06108.

Mc89 McKenzie-Carter, M. A. and Lyon, R. E., "Methodology for Assessing the Radiological Consequences of Radioactive Releases from the CIT Facility at PPPL," EGG-ESE-8600, Idaho National Engineering Laboratory (INEL) Informal Report (August 1989) 73 pp.

MP91a Malcolm Pirnie, February 1991, Underground Storage Tank/Groundwater Investigation. 4 volumes.

MP91b Malcolm Pirnie, February 1991, Investigation of Correlation Between Petrex Soil Gas Survey Results and Groundwater Quality, 4 volumes.

MP91c Malcolm Pirnie, March 1991, Study of Detention Basin Impact on Groundwater Elevations and Flow Direction, Addendum to : Investigation of Correlation Between Petrx\& Soil Gas Survey Results and Groundwater Quality.

MP91d Malcolm Pirnie, April 1991, Discharge Investigation and Corrective Action Report, Case \#90-10-22-1141.

MP91e Malcolm Pirnie, August 1991, Impact of Hydraulic Fluid Spill on Groundwater Quality.

MP91f Malcolm Pirnie, August 1991, Solvent and Hazardous Constituent Usage Survey.

MP91g Malcolm Pirnie, September 1991, Underoround Storage Tank Excavation Area Groundwater Monitoring First Quarter Report, 2 volumes.

MP91h Malcolm Pirnie, December 1991, Underground Storage Tank Excavation Area Groundwater Monitoring Second Ouarter Report.

MP92a Malcolm Pirnie, March 1992, Underground Storage Tank Excavation Area Groundwater Monitoring Third Ouarter Report. 
MP92b Malcolm Pimie, April 1992, Certified by R. P. Brownell, P. E. , Spill Prevention Control and Countermeasure (SPCC) Plan for Princeton Plasma Physics Laboratory.

MP92c Malcolm Pirnie, June 1992, Underground Storage Tank Excayation Area Groundwater Monitoring Fourth Quarter Report.

Mu77 Murphy, C. E., Jr., Watts, J. R., and Corey, J. C., 1977, "Environmental Tritium Transport from Atmospheric Release of Molecular Tritium," Health Physics, 33, 325-331.

Mu82 Murphy, C. E., Jr., Sweet, C. W., and Fallon, R. D., 1982, "Tritium Transport Around Nuclear Facilities," Nuclear Safety, 23, 667-685.

Mu90 Murphy, C. E., Jr., 1990, The Transport. Dispersion. and Cycling of Tritium in the Environment, Savannah River Site Report, WSRC-RP-90-462, UC702, 70 pp.

NAC90 Northeastern Analytical Corporation, July 90, Quality Assurance/Quality Control OA/OCPlan. Northeastern Analytical Corporation, Marlton, NJ, NAC/ENL: QA100.00.

Ne90 Nelson, D., September 1990, Einal Report on the Findings of the Petrex Soil Gas Survey Conducted at Princeton Plasma Physics Laboratory on the Forrestal Campus in Plainsbore. New Jersey, Northeast Research Institute, Inc. Report, Farmington, Conn.

NJDEPE90 NJ Department of Environmental Protection and Energy (NJDEPE), May 25, 1990, W. S. Samsel, Chief, Bureau of Aquifer Protection to H. C. Mix, DOE/PAO, letter.

NJDEPE91a NJ Department of Environmental Protection and Energy (NJDEPE), November 3, 1991, Robert J. Kotch, P.E. P.P., Chief, Bureau of Discharge Prevention to Potentially Affected Party, letter.

NJDEPE91b NJ Department of Environmental Protection and Energy (NJDEPE), February 14, 1991, Irene Kropp, Bureau of Groundwater Pollution Abatement, to $\mathrm{H}$. C. Mix, DOE/PAO, "Re: Monitoring Well Installation at Hydraulic Oil Contamination Site Princeton Plasma Physics Laboratory."

NJDEPE91c NJ Department of Environmental Protection and Energy (NJDEPE), March 2, 1992, Irene Kropp, Bureau of Groundwater Pollution Abatement, to H. C. Mix, DOE/PAO, "Re: Correspondence Dated January 24, 1992 - Soil Sampling Results from Underground Storage Tank (UST) Excavations."

Nor92 Normandeau Assoviates, July 1992, "Freshwater Wetlands and Transition Area Thelineation," map.

Os88 Ostlund, G., University of Miami, private communication, November 1988.

PSAR78 Preliminary Safety Analysis Report. Princeton Plasma Physics Laboratory Tokamak Fusion Test Reactor 1978. 
REML90, March 1990, Radiological Environmental Monitoring Laboratory Manual. Princeton Plasma Physics Laboratory Health Physics Document.

RES92a Raritan Enviro Sciences, September 1992, Underground storage Tank Excayation Area Groundwater Monitoring. Fifth Quarter Report.

RES92b Raritan Enviro Sciences, February 1993, Underground storage Tank Excayation Area Groundwater Monitoring Sixth Quarter Report.

RES92c Raritan Enviro Sciences, March 1993, Underground storage Tank Excavation Area Groundwater Monitoring. Seventh Ouarter Report.

Sa89 Savy, J. B., "Princeton Plasma Physics Laboratory (PPPL) Seismic Hazard Analysis," UCID Report-21829 (October 1989) 138 pp.

SAD91 Safety Assessment Document (SAD) for the Princeton Beta Experiment Modified (PBX-M), October 25, 1991, 136 pp.

SBRSA93 Stony Brook Regional Sewerage Authority, February 1993, SBRSA Proposed Service Rule Revisions.

St81 Steiner, P. A., 1981, An Aerial Radiological Survey of the Princeton Plasma Physics Laboratory and Surrounding Area, U.S. DOE Remote Sensing Laboratory Report, EGG-1182-1806, UC-41.

St82 Strenge, D. L., Kennedy, W. E., Jr, and Corley, J. P., 1982, Environmental Dose Assessment Methods for Normal Operations of DOE Nuclear Sites, PNL4410/UC-11.

St88a Stencel, J. R. and Parsells, R. F., Editors, April 1988, Safety Assessment Document (SAD) for the Princeton Beta Experiment Modification (PBX-M), Princeton Plasma Physics Laboratory Report PPPL-2496.

St88b Stencel, J. R., Gilbert, J. D., Griesbach, O. A., and Greco, J. M., "TFTR Health Physics Tritium Measurements Following D-D Operations," Fusion Technology, 14, Part 2A; 1047-1053; Sept. 1988.

St88c Stencel, J. R., May 1988, Environmental Monitoring Report for Calendar Year 1987, Princeton Plasma Physics Laboratory Report PPPL-2496.

St88d Stencel, J. R., 1988, "Environmental Protection Spill Cleanup Report EP8801, NB Transformer, January 19, 1988," DEP ID \#88-01-19-1617, Internal PPPL Environmental Protection Committee Report.

St89 Start, G. E., Dickson, C. R., Sagendorf, J. F., Ackermann, G. R., Clawson, K. L., Johnson, R. C., and Hukari, N. F., "Atmospheric Diffusion for Airflows in the Vicinity of the James Forrestal Campus, Princeton University," Final Report, U.S. Department of Commerce, National Oceanic and Atmospheric Administration, Environmental Research Laboratories, Air Resources Laboratory Field Research Division, Idaho Falls, Idaho, Vol. 1 (May 1989) 84 pp, Vol. 2 (June 1989) $385 \mathrm{pp}$. 
St90 Stencel, J. R., August 1990, "Environmental Protection Spill Cleanup Report EP90-2, Nitric Acid-Acetone Incident August 9, 1990," JRS-1841, NJDEP ID. No. 90-08-09-1320, PPPL Internal Report of the Environmental Protection Committee.

St91a Stencel, J. R., and Turrin, R. P., March 1991, Environmental Monitoring Report for Calendar Year 1989, Princeton Plasma Physics Laboratory Report PPPL2739.

St91b Stencel, J. R., and Finley, V. L.. December 1991, Environmental Monitoring Report for Calendar Year 1990, Princeton Plasma Physics Laboratory Report PPPL2800.

St92 Stencel, J. R., April 29, 1992, letter to H. C. Mix, DOE/PAO, "Calendar Year (CY1991) Air Emissions Annual Report to the Environmental Protection Agency."

Sz87 Szabo, Z. and Zapecza, O. S., "Relation Between Natural Radionuclide Activities and Chemical Constituents in Groundwater in the Newark Basin, New Jersey," Radon, Radium, and Other Radioactivity in Groundwater, Hydrogeologic Impact and Application to Indoor Airborne Contamination, Proceedings of the National Water Well Association Conference, April 7-9, 1987, Somerset, NJ, available from Lewis Publishers.

TFTR TFTR Technical Safety Requirements, OPR-R-23.

Tu90 Turrin, R. P., April 1990, "Environmental Protection Spill Cleanup Report EP90-1, Chromium Sands Spill in the Plant Maintenance and Engineering Yard," RPT66, NJDEP ID. No. 90-03-23-1551, PPPL Internal Report of the Environmental Protection Committee.

Vo82 Volchok, H. L., and de Planque, G., 1982, EML Procedures Manual HASL 300, Department of Energy, Environmental Measurements Laboratory, 376 Hudson St., NY, NY 10014.

Wi93a Wieczorek, M., March 1993, "PPPL Air Inventory Survey C and D Sites."

Wi93a Wieczorek, M., March 1993, "PPPL Sanitary Sewer Survey C and D Sites."

Za87 Zapecza, O. S. and Szabo, Z., "Source and Distribution of Natural Radioactivity in Groundwater in the Newark Basin, New Jersey," Radon, Radium, and Other Radioactivity in Groundwater, Hydrogeologic Impact and Application to Indoor Airborne Contamination, Proceedings of the National Water Well Association Conference, April 7-9, 1987, Somerset, NJ, available from Lewis Publishers. 
Table 1. TFTR Radiological Design Objectives and Regulatory LImitg(a)

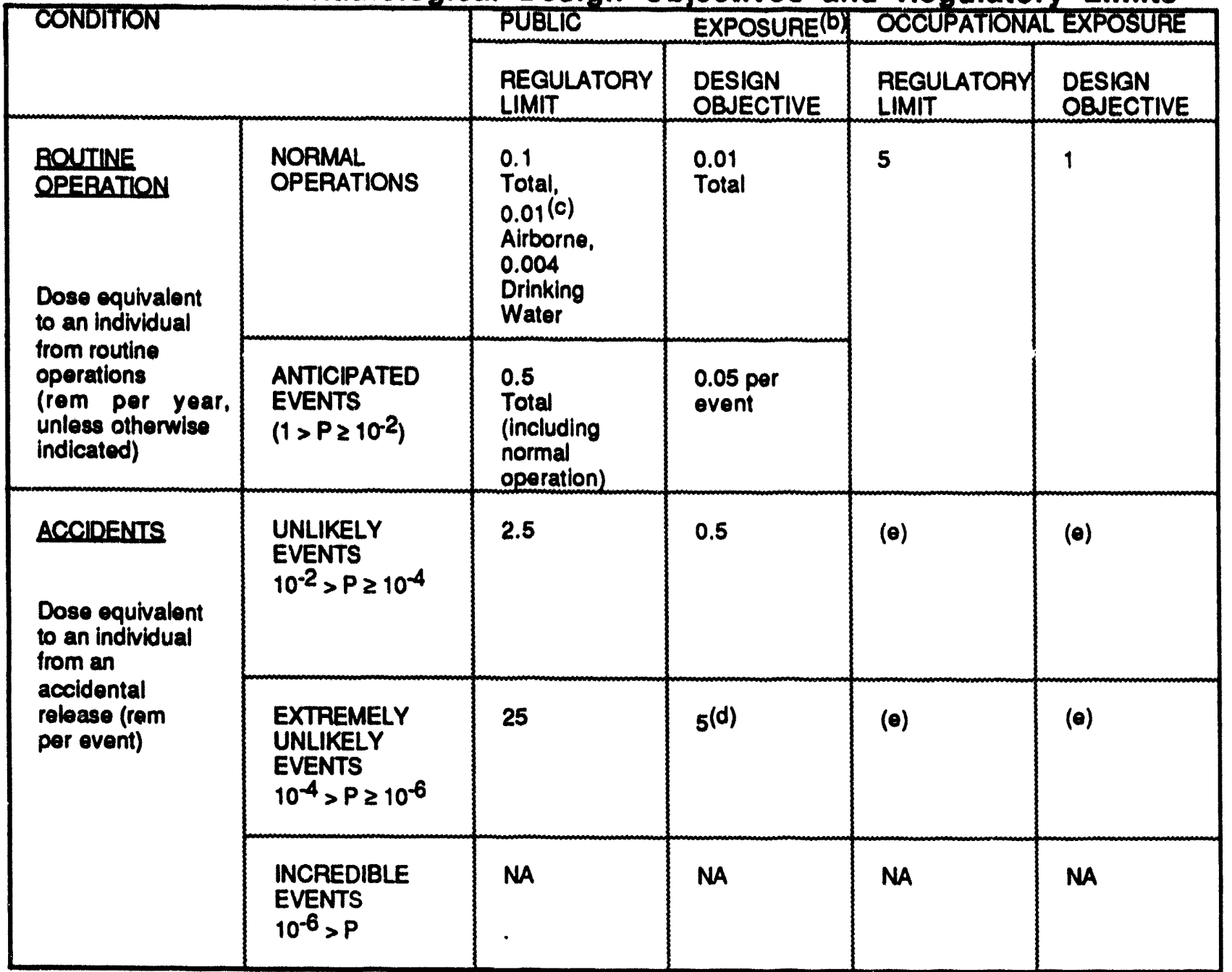

$P=$ Probability of occurrence in a year.

(a) All operations must be planned to incorporate the radiation safety guidelines, practices and procedures included in PPPL ESHD 5008, Section 10.

(b) Evaluated at the PPPL site boundary.

(c) Compliance with this limit is to be determined by calculating the highest effective dose equivalent to any member of the public at any offsite point where there is a residence, school, business or office.

(d) For design basis accidents (DBAs), l.e., postulated accidents or natural forces and resulting conditions for which the confinement structure, systems, components and equipment must meet their functional goals, the design objective is $0.5 \mathrm{rem}$.

(e) See PPPL ESHD-5008, Section 10, Chapter 12 for emergency personnel exposure limits. 
Path 1.D.
A1
A2
A3
L1
L2
L3
Atmospheric ---> Whole Body Exposure
Atmospheric ---> Inhalation Exposure
Atmospheric ---> Deposition on Soil \& Vegetation, Ingestion, Whole Body Exposure
Drinking Water Supply --> Man
Liquid
Water Way --->
External Exposure
Liquid Water Way --->
Fish ---> Man

\section{Discharge Pathway}


Table 3. Monitoring Program Covering Critical Pathways

\begin{tabular}{|c|c|c|c|c|}
\hline $\begin{array}{l}\text { Type of } \\
\text { Sample } \\
\end{array}$ & $\begin{array}{c}\text { Critical Path } \\
\text { I.D. }\end{array}$ & $\begin{array}{c}\text { Sample Point } \\
\text { Description }\end{array}$ & $\begin{array}{l}\text { Sampling } \\
\text { Frequency }\end{array}$ & Analysis \\
\hline Surface & $\begin{array}{c}L 1, L 2, L 3 \\
\& \\
A 3\end{array}$ & $\begin{array}{l}\text { 1) Cooling Water } \\
\text { Discharge } \\
\text { Drainage } \\
\text { 2) Bee Brook } \\
\text { Upstream \& } \\
\text { Downstream } \\
\text { 3) D\&R Canal }\end{array}$ & Monthly & $\begin{array}{l}\text { Tritium and Gamma } \\
\text { Spectroscopy }\end{array}$ \\
\hline Soil \& Sod & A3 & Within $1 \mathrm{~km}$ radius & & $\begin{array}{l}\text { Tritium and Gamma } \\
\text { Spectroscopy }\end{array}$ \\
\hline $\begin{array}{l}\text { Biota (Fruits \& } \\
\text { Vegetables) }\end{array}$ & A3 & Within $3 \mathrm{~km}$ radius & Seasonal & $\begin{array}{l}\text { Tritium \& Gamma } \\
\text { Spectroscopy }\end{array}$ \\
\hline Surface Water & L1, L2 & $\begin{array}{l}\text { Liquid Effluent } \\
\text { Collection Tanks }\end{array}$ & $\begin{array}{l}\text { As Required by } \\
\text { Filling }\end{array}$ & $\begin{array}{l}\text { Tritium and Gamma } \\
\text { Spectroscopy, } \\
\text { Volume }\end{array}$ \\
\hline Air & $A 1-A 3$ & Test Cell & Continuous & $\begin{array}{c}\text { Activated Air } \\
\text { (Gross b) } 3 \mathrm{H}(\mathrm{HT} \text { and } \\
\text { HTO) }\end{array}$ \\
\hline Air & $A 1-A 3$ & Vault & Continuous & $3 \mathrm{H}(\mathrm{HT}$ and $\mathrm{HTO})$ \\
\hline Air & A1-A3 & $\begin{array}{c}\text { HVAC } \\
\text { Discharge (Stack) }\end{array}$ & Continuous & $\begin{array}{c}\text { Activated Air } \\
\text { (Gross b) HT and HTO, } \\
\text { Particulates, Volume }\end{array}$ \\
\hline $\begin{array}{l}\text { Direct \& Air (on- } \\
\text { site) }\end{array}$ & & $\begin{array}{l}4 \text { Locations at } \\
\text { TFTR Facility } \\
\text { Boundary }\end{array}$ & Continuous & $\begin{array}{c}\text { g, n, }{ }^{3} \mathrm{H}(\mathrm{HT} \text { and } \\
\text { HTO), Gross b for } \\
\text { activated air \& } \\
\text { particulates with } \\
\text { Gamma } \\
\text { Spectroscopy, TLD }\end{array}$ \\
\hline $\begin{array}{l}\text { Direct \& Air (off- } \\
\text { site) }\end{array}$ & & $\begin{array}{l}6 \text { Locations off- } \\
\text { site within } 1 \mathrm{~km} \\
\text { radius }\end{array}$ & $\begin{array}{l}\text { Continuous } \\
\text { (integrated) }\end{array}$ & $\begin{array}{l}3 \mathrm{H}(\mathrm{HT} \text { and } \mathrm{HTO}), \mathrm{TLD} \\
\text { for air g, Gamma Spec. } \\
\text { for particulates }\end{array}$ \\
\hline
\end{tabular}


Table $4^{*}$

Population of Municipalities Within 0-10 Miles of PPPL 1985-2010

\begin{tabular}{|c|c|c|c|c|c|c|}
\hline Municipality & 19851 & 1995 & 2000 & 2005 & 2010 & \\
\hline $\begin{array}{l}\text { Mercer County } \\
(\text { Total })^{2}\end{array}$ & 317,685 & 349,700 & 359,400 & 364,200 & 377,100 & Mercer County (Total) \\
\hline $\begin{array}{l}\text { Mercer County (Part) } \\
\text { East Windsor Twp. } \\
\text { Hightstown Borough } \\
\text { Hamilton Twp. } \\
\text { Hopewell Twp. } \\
\text { Hopewell Borough } \\
\text { Pennington Borough } \\
\text { Lawrence Twp. } \\
\text { Princeton Twp. } \\
\text { Princeton Borough } \\
\text { Washington Twp. } \\
\text { West Windsor Twp. }\end{array}$ & $\begin{array}{r}190,683 \\
22,682 \\
4,494 \\
85,766 \\
11,040 \\
2,013 \\
2,232 \\
22,804 \\
14,202 \\
12,031 \\
3,719 \\
9,700\end{array}$ & $\begin{array}{r}219,550 \\
24,750 \\
5,050 \\
88,850 \\
13,025 \\
2,075 \\
2,300 \\
31,100 \\
14,550 \\
12,650 \\
8,650 \\
16,550\end{array}$ & $\begin{array}{r}228,100 \\
26,000 \\
5,100 \\
90,000 \\
15,000 \\
2,100 \\
2,300 \\
33,900 \\
14,700 \\
12,700 \\
8,800 \\
17,550\end{array}$ & $\begin{array}{r}230,550 \\
26,350 \\
5,100 \\
91,200 \\
15,200 \\
2,100 \\
2,350 \\
34,000 \\
14,900 \\
12,700 \\
8,900 \\
17,750\end{array}$ & $\begin{array}{r}240,500 \\
29,350 \\
5,100 \\
94,450 \\
16,200 \\
2,100 \\
2,400 \\
34,100 \\
15,400 \\
12,700 \\
9,200 \\
19,500\end{array}$ & $\begin{array}{l}\text { Mercer County (Part) } \\
\text { East Windsor Twp. } \\
\text { Hightstown Borough } \\
\text { Hamilton Twp. } \\
\text { Hopewell Twp. } \\
\text { Hopewell Borough } \\
\text { Pennington Borough } \\
\text { Lawrence Twp. } \\
\text { Princeton Twp. } \\
\text { Princeton Borough } \\
\text { Washington Twp. } \\
\text { West Windsor Twp. }\end{array}$ \\
\hline $\begin{array}{l}\text { Middlesex County } \\
\text { (Total) }^{2}\end{array}$ & 626,703 & 695,432 & 724,610 & 760,800 & 791,800 & Middlesex County (Total) \\
\hline $\begin{array}{l}\text { Middlesex County } \\
\text { (Pant) }\end{array}$ & 121,984 & 171,183 & 192,396 & 202,000 & 219,100 & Middlesex County (Part) \\
\hline $\begin{array}{l}\text { Cranbury Twp. } \\
\text { East Brunswick Twp. } \\
\text { Helmetta Borough } \\
\text { Monroe Twp. } \\
\text { Jamesburg Borough } \\
\text { North Brunswick Twp. } \\
\text { Plainsboro Twp. } \\
\text { South Brunswick Twp }\end{array}$ & $\begin{array}{r}2,145 \\
40,770 \\
973 \\
19,255 \\
4,402 \\
25,427 \\
9,040 \\
\text { p. } 19,972\end{array}$ & $\begin{array}{r}5,695 \\
43,630 \\
965 \\
28,711 \\
4,723 \\
31,495 \\
15,662 \\
40,304\end{array}$ & $\begin{array}{r}8,033 \\
44,753 \\
949 \\
34,737 \\
4,805 \\
33,916 \\
17,161 \\
48,042\end{array}$ & $\begin{array}{r}8,450 \\
47,000 \\
950 \\
36,500 \\
5,050 \\
35,600 \\
18,000 \\
50,450\end{array}$ & $\begin{array}{r}8,800 \\
50,900 \\
950 \\
38,200 \\
5,050 \\
37,000 \\
20,700 \\
57,500\end{array}$ & $\begin{array}{l}\text { Cranbury Twp. } \\
\text { East Brunswick Twp. } \\
\text { Helmetta Borough } \\
\text { Monroe Twp. } \\
\text { Jamesburg Borough } \\
\text { North Brunswick Twp. } \\
\text { Plainsboro Twp. } \\
\text { South Brunswick Twp. }\end{array}$ \\
\hline $\begin{array}{c}\text { Somerset County } \\
\text { (Total) }^{2}\end{array}$ & 210,318 & 250,025 & 263,800 & 279,765 & 295,730 & Somerset County (Total) \\
\hline $\begin{array}{c}\text { Somerset County } \\
\text { (Part) }\end{array}$ & 65,276 & 89,280 & 97,820 & 106,610 & 115,400 & Somerset County (Part) \\
\hline $\begin{array}{l}\text { Franklin Twp. } \\
\text { Hillsborough Twp } \\
\text { Montgomery Twp. } \\
\text { Rocky Hill Borough }\end{array}$ & $\begin{array}{r}33,952 \\
22,652 \\
7,970 \\
702\end{array}$ & $\begin{array}{r}47,945 \\
28,485 \\
12,145 \\
705\end{array}$ & $\begin{array}{r}52,790 \\
30,900 \\
13,420 \\
710\end{array}$ & $\begin{array}{r}57,790 \\
33,375 \\
14,725 \\
720\end{array}$ & $\begin{array}{r}62,790 \\
35,850 \\
16,030 \\
730\end{array}$ & $\begin{array}{l}\text { Franklin Twp. } \\
\text { Hillsborough Twp. } \\
\text { Montgomery Twp. } \\
\text { Rocky Hill Borough }\end{array}$ \\
\hline $\begin{array}{l}\text { Monmouth County ( } \\
\text { Total) } \\
\text { Millstone Twp. }\end{array}$ & $\begin{array}{r}530,913 \\
4,234\end{array}$ & $\begin{array}{r}568,100 \\
5,617\end{array}$ & $\begin{array}{r}591,600 \\
7,000\end{array}$ & $\begin{array}{r}604,300 \\
9,286\end{array}$ & $\begin{array}{r}613,450 \\
11,571\end{array}$ & $\begin{array}{l}\text { Monmouth County } \\
\text { Millstone Twp. }\end{array}$ \\
\hline
\end{tabular}

\footnotetext{
Taken from Bender [Be87a].

1 New Jersey Department of Labor. Population Estimates for New Jersey, July 1, 1985.

2 See methodology in Appendix of Be87a for details on the source and derviation of County and Municipal Projections.
} 
Table $5^{*}$

Population of Counties Within 0-50 Miles of PPPL
$1985-2010$

\begin{tabular}{|c|c|c|c|c|c|c|}
\hline County & $\begin{array}{c}1985 \\
\text { Estimates }\end{array}$ & $\begin{array}{l}1995 \\
\text { Projections }\end{array}$ & $\begin{array}{l}2000 \\
\text { Projections }\end{array}$ & $\begin{array}{l}2005 \\
\text { Projections }\end{array}$ & $\begin{array}{l}2010 \\
\text { Projections }\end{array}$ & \\
\hline New Jersey ${ }^{1}$ & $7,562,000$ & $8,154,000$ & $8,450,300$ & $8,685,200$ & $8,895,700$ & New Jersey \\
\hline $\begin{array}{l}\text { Atlantic } \\
\text { Bergen } \\
\text { Burlington } \\
\text { Camden } \\
\text { Essex } \\
\text { Gloucester } \\
\text { Hudson } \\
\text { Hunterdon } \\
\text { Mercer } \\
\text { Middlesex } \\
\text { Monmouth } \\
\text { Morris } \\
\text { Ocean } \\
\text { Passaic } \\
\text { Somerset } \\
\text { Sussex } \\
\text { Union } \\
\text { Warren }\end{array}$ & $\begin{array}{r}205,100 \\
841,200 \\
380,100 \\
488,100 \\
845,700 \\
207,100 \\
555,900 \\
92,800 \\
317,700 \\
626,700 \\
530,900 \\
417,100 \\
380,000 \\
461,400 \\
210,318 \\
119,600 \\
506,700 \\
85,200\end{array}$ & $\begin{array}{r}245,100 \\
861,800 \\
437,100 \\
555,400 \\
794,000 \\
234,500 \\
560,100 \\
104,500 \\
349,700 \\
695,432 \\
568,100 \\
479,900 \\
449,600 \\
468,600 \\
250,025 \\
146,100 \\
534,500 \\
92,700\end{array}$ & $\begin{array}{r}260,100 \\
878,700 \\
467,200 \\
577,200 \\
795,500 \\
249,100 \\
548,100 \\
113,000 \\
359,400 \\
724,610 \\
591,600 \\
510,500 \\
484,400 \\
469,100 \\
263,800 \\
159,600 \\
539,700 \\
96,200\end{array}$ & $\begin{array}{r}272,300 \\
891,900 \\
494,900 \\
597,300 \\
779,900 \\
263,500 \\
528,500 \\
121,900 \\
364,200 \\
760,800 \\
604,300 \\
540,800 \\
515,800 \\
466,500 \\
279,765 \\
172,900 \\
540,900 \\
99,300\end{array}$ & $\begin{array}{l}283,200 \\
904,000 \\
521,300 \\
616,700 \\
762,300 \\
277,400 \\
507,300 \\
131,000 \\
377,100 \\
791,800 \\
613,450 \\
570,500 \\
545,900 \\
462,000 \\
295,730 \\
185,700 \\
540,000 \\
101,900\end{array}$ & $\begin{array}{l}\text { Atlantic } \\
\text { Bergen } \\
\text { Burlington } \\
\text { Camden } \\
\text { Essex } \\
\text { Gloucester } \\
\text { Hudson } \\
\text { Hunterdon } \\
\text { Mercer } \\
\text { Middlesex } \\
\text { Monmouth } \\
\text { Morris } \\
\text { Ocean } \\
\text { Passaic } \\
\text { Somerset } \\
\text { Sussex } \\
\text { Union } \\
\text { Warren }\end{array}$ \\
\hline
\end{tabular}

\begin{tabular}{|c|c|c|c|c|c|c|}
\hline New York ${ }^{2}$ & $17,783,000$ & $18,314,022$ & $18,548,262$ & $18,750,076$ & $18,948,273$ & New York \\
\hline $\begin{array}{l}\text { Bronx } \\
\text { Kings } \\
\text { Nassau } \\
\text { New York } \\
\text { Queens } \\
\text { Richmond }\end{array}$ & $\begin{array}{r}1,198,598 \\
2,248,139 \\
1,332,393 \\
1,455,619 \\
1,917,172 \\
371,679\end{array}$ & $\begin{array}{r}1,199,410 \\
2,228,361 \\
1,344,197 \\
1,454,633 \\
1,919,057 \\
419,706\end{array}$ & $\begin{array}{r}1,205,047 \\
2,232,835 \\
1,333,458 \\
1,454,251 \\
1,925,510 \\
443,048\end{array}$ & $\begin{array}{r}1,213,270 \\
2,242,890 \\
1,315,938 \\
1,456,292 \\
1,933,829 \\
465,818\end{array}$ & $\begin{array}{r}1,224,052 \\
2,254,228 \\
1,292,457 \\
1,456,707 \\
1,953,634 \\
489,111\end{array}$ & $\begin{array}{l}\text { Bronx } \\
\text { Kings } \\
\text { Nassau } \\
\text { New York } \\
\text { Queens } \\
\text { Richmond }\end{array}$ \\
\hline Pennsylvania ${ }^{3}$ & $11,863,674$ & $12,100,149$ & $12,101,253$ & $12,161,780$ & $12,222,306$ & Pennsylvania \\
\hline $\begin{array}{l}\text { Bucks } \\
\text { Chester } \\
\text { Delaware } \\
\text { Lehigh } \\
\text { Monroe } \\
\text { Montgomery } \\
\text { Northhampton } \\
\text { Philadelphia }\end{array}$ & $\begin{array}{r}512,705 \\
334,311 \\
557,180 \\
277,914 \\
78,967 \\
663,164 \\
231,430 \\
1,637,434\end{array}$ & $\begin{array}{r}576,716 \\
379,733 \\
541,442 \\
291,083 \\
104,133 \\
692,521 \\
244,668 \\
1,599,620\end{array}$ & $\begin{array}{r}601,168 \\
395,958 \\
531,068 \\
294,836 \\
117,583 \\
698,281 \\
249,000 \\
1,513,674\end{array}$ & $\begin{array}{r}636,276 \\
418,726 \\
525,279 \\
300,762 \\
134,162 \\
712,666 \\
255,275 \\
1,472,959\end{array}$ & $\begin{array}{r}673,345 \\
442,802 \\
519,554 \\
306,808 \\
153,079 \\
727,346 \\
261,707 \\
1,433,333\end{array}$ & $\begin{array}{l}\text { Bucks } \\
\text { Chester } \\
\text { Delaware } \\
\text { Lehigh } \\
\text { Monroe } \\
\text { Montgomery } \\
\text { Northhampton } \\
\text { Philadephia }\end{array}$ \\
\hline
\end{tabular}

\footnotetext{
Taken from Bender [Be87a].

1 Office of Demographic and Economic Analysis, N.J. Department of Labor and Industry, 1986.

2 State Data Center, New York State Department of Commerce, 1985.

3 State Data Center, Pennsylvania Department of Commerce, 1986. See methodology in Be87 Appendix for details on 2005 and 2010 projections.
} 


\section{Table $6^{*}$}

Population of Metropolitan Areas Within 50 Miles of PPPL

\begin{tabular}{|c|c|c|c|}
\hline Metropolitan Areas ${ }^{1}$ & $\begin{array}{l}1980 \\
\text { Census }\end{array}$ & $\begin{array}{l}\text { July } 1985 \\
\text { Estimate }\end{array}$ & $\begin{array}{l}\text { Percent } \\
\text { Change }\end{array}$ \\
\hline $\begin{array}{l}\text { Allentown-Bethlehem MSA } \\
\text { (NJ Portion) }\end{array}$ & 84,429 & 85,200 & $0.9 \%$ \\
\hline Jersey City, NJ PMSA & 556,972 & 555,900 & $-0.2 \%$ \\
\hline Monmouth-Ocean PMSA & 849,211 & 910,900 & $7.3 \%$ \\
\hline $\begin{array}{l}\text { Middlesex-Somerset-Hunterdon } \\
\text { PMSA }\end{array}$ & 886,383 & 929,800 & $4.9 \%$ \\
\hline New York, NY CMSA & $8,274,961$ & $8,410,058$ & $1.6 \%$ \\
\hline Newark, NJ PMSA & $1,879,147$ & $1,889,000$ & $0.5 \%$ \\
\hline Bergen-Passaic PMSA & $1,292,970$ & $1,302,600$ & $0.7 \%$ \\
\hline $\begin{array}{l}\text { Philadelphia, PA PMSA } \\
\text { (NJ Portion) }\end{array}$ & $1,034,109$ & $1,075,300$ & $4.0 \%$ \\
\hline Trenton, NJ PMSA & 307,863 & 317,700 & $3.2 \%$ \\
\hline
\end{tabular}

- Taken from Bender [Be87a].

$1 \mathrm{MSA}=$ Metropolitan Statistical Area

CMSA = Consolidated Metropolitan Statistical Area

PMSA = Primary Metropolitan Statistical Area

Source: State of New Jersey, Department of Labor; New York State Department of Commerce 
Table $7^{*}$

1995 Population Estimates Within Annular Sectors, 0-10 Miles

$\begin{array}{crrrrrrrr} & & & & & & & & \text { Total } \\ \text { Sector } & \text { Miles } & \text { Miles } & \text { Miles } & \text { Miles } & \text { Miles } & \text { Miles } & \text { Miles } & \text { Sector } \\ & & & & & & & & \\ \text { N } & 0 & 134 & 387 & 0 & 91 & 6,241 & 6,853 & \text { N } \\ \text { NNE } & 0 & 27 & 388 & 3,340 & 5,242 & 12,841 & 21,838 & \text { NNE } \\ \text { NE } & 0 & 0 & 0 & 486 & 902 & 21,084 & 22,472 & \text { NE } \\ \text { ENE } & 0 & 1,551 & 273 & 268 & 689 & 5,072 & 7,853 & \text { ENE } \\ \text { E } & 0 & 0 & 268 & 134 & 1,678 & 13,695 & 15,775 & \text { E } \\ \text { ESE } & 0 & 827 & 2,140 & 1,605 & 2,235 & 5,195 & 12,002 & \text { ESE } \\ \text { SE } & 151 & 1,605 & 291 & 338 & 493 & 20,928 & 23,806 & \text { SE } \\ \text { SSE } & 484 & 1,454 & 894 & 166 & 803 & 11,042 & 14,843 & \text { SSE } \\ \text { S } & 0 & 982 & 4,675 & 3,093 & 2,354 & 5,559 & 16,663 & \text { S } \\ \text { SSW } & 4 & 188 & 3,344 & 2,522 & 2,908 & 32,176 & 41,142 & \text { SSW } \\ \text { SW } & 0 & 1,077 & 332 & 544 & 2,796 & 21,450 & 26,199 & \text { SW } \\ \text { WSW } & 0 & 989 & 2,828 & 1,130 & 1,594 & 10,828 & 17,369 & \text { WSW } \\ \text { W } & 0 & 2,321 & 6,005 & 6,963 & 2,487 & 9,277 & 27,053 & \text { W } \\ \text { WNW } & 53 & 585 & 800 & 3,256 & 128 & 4,438 & 9,260 & \text { WNW } \\ \text { NW } & 0 & 1,365 & 898 & 335 & 468 & 4,716 & 7,782 & \text { NW } \\ \text { NNW } & 0 & 803 & 668 & 268 & 671 & 9,487 & 11,897 & \text { NNW } \\ \text { Totals } & 692 & 13,908 & 24,191 & 24,448 & 25,539 & 194,029 & 282,807 & \text { Totals } \\ & & & & & & & & \end{array}$

\footnotetext{
"Taken from Bender [Be87a]
} 
Table $8^{\circ}$

2000 Population Estimates Within Annular Sectors, 0-10 Miles

Total

\begin{tabular}{crrrrrrrr}
\hline & 0-1 & $1-2$ & $2-3$ & $3-4$ & $4-5$ & $5-10$ & $0-10$ & \\
Secter & Miles & Miles & Miles & Miles & Miles & Miles & Miles & Secter \\
& & & & & & & & \\
N & 0 & 146 & 421 & 0 & 99 & 6,792 & 7,458 & N \\
NNE & 0 & 29 & 422 & 3,635 & 5,560 & 13,974 & 23,620 & NNE \\
NE & 0 & 0 & 0 & 656 & 1,217 & 22,582 & 24,455 & NE \\
ENE & 0 & 1,688 & 297 & 292 & 895 & 5,520 & 8,692 & ENE \\
E & 0 & 0 & 292 & 146 & 2,261 & 14,904 & 17,603 & E \\
ESE & 0 & 1,081 & 2,329 & 1,747 & 2,940 & 5,799 & 13,896 & ESE \\
SE & 164 & 1,747 & 393 & 368 & 609 & 21,615 & 24,896 & SE \\
SSE & 527 & 1,945 & 1,154 & 224 & 874 & 12,016 & 16,740 & SSE \\
S & 0 & 1,069 & 4,968 & 3,366 & 2,562 & 6,050 & 18,015 & S \\
SSW & 4 & 254 & 3,639 & 3,869 & 3,890 & 33,710 & 45,366 & SSW \\
SW & 0 & 1,172 & 252 & 469 & 4,566 & 22,473 & 28,932 & SW \\
WSW & 0 & 1,076 & 2,354 & 1,169 & 1,645 & 11,784 & 18,028 & WSW \\
W & 0 & 2,526 & 6,070 & 7,028 & 2,522 & 10,334 & 28,480 & W \\
WNW & 58 & 637 & 810 & 3,297 & 173 & 5,286 & 10,261 & WNW \\
NW & 0 & 1,485 & 909 & 347 & 509 & 5,132 & 8,382 & NW \\
NNW & 0 & 874 & 727 & 292 & 730 & 10,316 & 12,939 & NNW \\
Totals & 753 & 15,729 & 25,037 & 26,905 & 31,052 & 208,287 & 307,763 & Totals
\end{tabular}

Taken from Bender [Be87a] 


\section{Table $9^{\circ}$}

2005 Population Estimates Within Annular Sectors, 0-10 Miles

\begin{tabular}{crrrrrrrr}
\hline & $0-1$ & $1-2$ & $2-3$ & $3-4$ & $4-5$ & $5-10$ & $0-10$ & \\
Sector & Miles & Miles & Miles & Miles & Miles & Miles & Miles & Sector \\
& & & & & & & & \\
N & 0 & 151 & 435 & 0 & 102 & 7,014 & 7,702 & N \\
NNE & 0 & 30 & 436 & 3,754 & 5,688 & 14,431 & 24,339 & NNE \\
NE & 0 & 0 & 0 & 725 & 1,344 & 23,187 & 25,256 & NE \\
ENE & 0 & 1,743 & 307 & 302 & 978 & 5,701 & 9,031 & ENE \\
E & 0 & 0 & 302 & 151 & 2,496 & 15,392 & 18,341 & E \\
ESE & 0 & 1,184 & 2,405 & 1,804 & 3,224 & 6,043 & 14,660 & ESE \\
SE & 169 & 1,804 & 434 & 380 & 656 & 21,892 & 25,335 & SE \\
SSE & 544 & 2,143 & 1,259 & 247 & 903 & 12,409 & 17,505 & SSE \\
S & 0 & 1,104 & 5,086 & 3,476 & 2,646 & 6,248 & 18,560 & S \\
SSW & 4 & 281 & 3,758 & 4,211 & 4,286 & 34,329 & 46,869 & SSW \\
SW & 0 & 1,210 & 277 & 492 & 5,038 & 22,986 & 30,003 & SW \\
WSW & 0 & 1,111 & 2,496 & 1,185 & 1,666 & 12,170 & 18,628 & WSW \\
W & 0 & 2,609 & 6,096 & 7,054 & 2,536 & 10,761 & 29,056 & W \\
WNW & 60 & 658 & 814 & 3,313 & 191 & 5,628 & 10,664 & WNW \\
NW & 0 & 1,534 & 913 & 352 & 526 & 5,300 & 8,625 & NW \\
NNW & 0 & 903 & 751 & 302 & 754 & 10,651 & 13,361 & NNW \\
Totals & 777 & 16,465 & 25,769 & 27,748 & 33,034 & 214,142 & 317,935 & Totals
\end{tabular}

"Taken from Bender [Be87a] 
Table $1^{\circ}$

2010 Population Estimates Within Annular Sectors, 0-10 Miles

Total

$\begin{array}{lllllll}0-1 & 1-2 & 2-3 & 3-4 & 4-5 & 5-10 & 0-10\end{array}$

Sector Miles Miles Miles Miles Miles Miles Miles Sector

$\begin{array}{crrrrrrrc}\text { N } & 0 & 161 & 465 & 0 & 109 & 7,505 & 8,240 & \text { N } \\ \text { NNE } & 0 & 32 & 466 & 4,016 & 5,971 & 15,441 & 25,926 & \text { NNE } \\ \text { NE } & 0 & 0 & 0 & 875 & 1,625 & 24,521 & 27,021 & \text { NE } \\ \text { ENE } & 0 & 1,865 & 328 & 322 & 1,161 & 6,099 & 9,775 & \text { ENE } \\ \text { E } & 0 & 0 & 322 & 161 & 3,016 & 16,468 & 19,967 & \text { E } \\ \text { ESE } & 0 & 1,411 & 2,574 & 1,930 & 3,852 & 6,580 & 16,347 & \text { ESE } \\ \text { SE } & 182 & 1,930 & 525 & 407 & 749 & 22,503 & 26,306 & \text { SE } \\ \text { SSE } & 582 & 2,580 & 1,491 & 300 & 965 & 13,278 & 19,196 & \text { SSE } \\ \text { S } & 0 & 1,181 & 5,347 & 3,719 & 2,831 & 6,685 & 19,763 & \text { S } \\ \text { SSW } & 5 & 339 & 4,021 & 4,965 & 5,161 & 35,696 & 50,187 & \text { SSW } \\ \text { SW } & 0 & 1,295 & 333 & 542 & 6,080 & 23,797 & 32,047 & \text { SW } \\ \text { WSW } & 0 & 1,189 & 2,808 & 1,219 & 1,711 & 13,021 & 19,948 & \text { WSW } \\ \text { W } & 0 & 2,791 & 6,154 & 7,112 & 2,568 & 11,703 & 30,328 & \text { W } \\ \text { WNW } & 64 & 703 & 822 & 3,349 & 230 & 6,383 & 11,551 & \text { WNW } \\ \text { NW } & 0 & 1,641 & 923 & 363 & 563 & 5,671 & 9,161 & \text { NW } \\ \text { NNW } & 0 & 965 & .803 & 322 & 807 & 11,408 & 14,305 & \text { NNW } \\ \text { Totals } & 833 & 18,083 & 27,382 & 29,602 & 37,409 & 226,759 & 340,068 & \text { Totals }\end{array}$

\footnotetext{
'Taken from Bender [Be87a]
} 
Table $11^{\circ}$

1995 Population Estimates Within Annular Sectors, 10-50 Miles

Total

\begin{tabular}{|c|c|c|c|c|c|c|}
\hline & $10-20$ & $20-30$ & $30-40$ & $40-50$ & $10-50$ & \\
\hline Sector & Miles & Miles & Miles & Miles & Miles & Sector \\
\hline $\mathbf{N}$ & 77,600 & 43,286 & 209,880 & 82,344 & 413,110 & $\mathbf{N}$ \\
\hline NNE & 151,656 & 244,555 & 345,449 & 501,569 & $1,243,229$ & NNE \\
\hline NE & 189,192 & 466,816 & $1,282,528$ & $3,531,064$ & $5,469,602$ & NE \\
\hline ENE & 149,614 & 244,189 & $1,075,798$ & $1,444,205$ & $2,913,807$ & ENE \\
\hline$E$ & 48,224 & 130,379 & 80,443 & 0 & 259,046 & E \\
\hline ESE & 33,170 & 44,653 & 147,906 & 0 & 225,728 & ESE \\
\hline SE & 15,551 & 95,456 & 212,796 & 6,924 & 330,726 & SE \\
\hline SSE & 3,462 & 15,691 & 24,278 & 43,521 & 86,953 & SSE \\
\hline s & 3,798 & 65,696 & 13,638 & 3,437 & 86,568 & $S$ \\
\hline Ssw & 58,457 & 70,504 & 134,375 & 224,101 & 487,438 & SSW \\
\hline sw & 254,358 & 385,409 & $1,167,023$ & $1,035,758$ & $2,842,548$ & sw \\
\hline WSW & 55,741 & 167,298 & 319,088 & 309,761 & 851,889 & WSW \\
\hline w & 13,209 & 44,869 & 115,585 & 68,595 & 242,258 & W \\
\hline WNW & 9,332 & 14,133 & 17,280 & 265,316 & 306,061 & WNW \\
\hline NW & 15,675 & 21,005 & 72,663 & 91,959 & 201,302 & NW \\
\hline NNW & 29,653 & 15,445 & 38,640 & 25,334 & 109,071 & NNW \\
\hline Totals & $1,108,692$ & $2,069,384$ & $5,257,370$ & $7,633,889$ & $16,069,335$ & Totals \\
\hline
\end{tabular}


Table 12:

2000 Population Estimates Within Annular Sectors, 10-50 Miles

Total

\begin{tabular}{crrrrrr}
\hline & $10-20$ & $20-30$ & $30-40$ & $40-50$ & $10-50$ & \\
Secter & Miles & Milles & Miles & Miles & Miles & Sector \\
& & & & & & \\
N & 81,590 & $45,762$. & 223,566 & 89,117 & 440,035 & N \\
NNE & 158,049 & 250,338 & 354,421 & 507,150 & $1,269,959$ & NNE \\
NE & 193,977 & 478,786 & $1,286,928$ & $3,538,387$ & $5,498,078$ & NE \\
ENE & 152,903 & 256,310 & $1,081,795$ & $1,447,794$ & $2,938,803$ & ENE \\
E & 47,314 & 135,772 & 83,771 & 0 & 266,857 & E \\
ESE & 31,627 & 46,500 & 154,983 & 0 & 233,110 & ESE \\
SE & 16,320 & 102,409 & 229,267 & 7,460 & 355,455 & SE \\
SSE & 3,730 & 16,906 & 26,158 & 46,890 & 93,683 & SSE \\
S & 3,687 & 70,220 & 14,577 & 3,655 & 92,139 & S \\
SSW & 60,661 & 75,359 & 142,235 & 234,143 & 512,399 & SSW \\
SW & 262,872 & 389,374 & $1,137,316$ & $1,011,964$ & $2,801,526$ & SW \\
WSW & 57,234 & 172,994 & 316,136 & 311,387 & 857,751 & WSW \\
W & 13,585 & 46,771 & 118,755 & 69,700 & 248,812 & W \\
WNW & 10,091 & 15,112 & 18,138 & 269,393 & 312,733 & WNW \\
NW & 16,950 & 22,713 & 75,734 & 93,637 & 209,035 & NW \\
NNW & 31,170 & 16,701 & 40,885 & 26,602 & 115,358 & NNW \\
Totals & $1,141,761$ & $2,142,027$ & $5,304,664$ & $7,657,28016,245,732$ & Totals
\end{tabular}

\footnotetext{
Taken from Bender [Be87a]
} 
Table 13"

2010 Population Estimates Within Annular Sectors, 10-50 Miles

Total

\begin{tabular}{crrrrrr}
\hline & $10-20$ & $20-30$ & $30-40$ & $40-50$ & $10-50$ & \\
Sector & Miles & Mlles & Miles & Miles & Miles & Sector \\
& & & & & & \\
N & 91,018 & 51,262 & 250,373 & 102,263 & 494,916 & N \\
NNE & 172,722 & 258,877 & 362,497 & 510,423 & $1,304,520$ & NNE \\
NE & 209,861 & 499,736 & $1,260,255$ & $3,552,301$ & $5,522,153$ & NE \\
ENE & 164,784 & 277,228 & $1,099,303$ & $1,464,153$ & $3,005,468$ & ENE \\
E & 47,676 & 140,787 & 86,865 & 0 & 275,327 & E \\
ESE & 30,472 & 48,217 & 163,289 & 0 & 241,978 & ESE \\
SE & 17,263 & 114,276 & 258,374 & 8,407 & 398,321 & SE \\
SSE & 4,203 & 19,052 & 29,479 & 52,843 & 105,577 & SSE \\
S & 4,009 & 78,351 & 16,265 & 4,007 & 102,632 & S \\
SSW & 65,172 & 84,086 & 156,390 & 252,607 & 558,255 & SSW \\
SW & 284,516 & 410,918 & $1,123,253$ & 998,753 & $2,817,440$ & SW \\
WSW & 61,714 & 190,521 & 321,293 & 322,263 & 895,791 & WSW \\
W & 15,337 & 52,386 & 128,998 & 73,884 & 270,605 & W \\
WNW & 11,698 & 17,340 & 20,389 & 281,867 & 331,295 & WNW \\
NW & 19,650 & 26,331 & 81,471 & 98,437 & 225,889 & NW \\
NNW & 34,761 & 19,362 & 45,199 & 28,849 & 128,171 & NNW \\
Totals & $1,234,856$ & $2,288,731$ & $5,403,694$ & $7,751,05916,678,339$ & Totals
\end{tabular}

- Taken from Bender [Be87a] 
Table 14. Summary of Environmental Permits

\begin{tabular}{|c|c|c|c|c|}
\hline $\begin{array}{l}\text { NJDEPE } \\
\text { Pormit No. }\end{array}$ & Typo & $\begin{array}{l}\text { Issue } \\
\text { Date }\end{array}$ & $\begin{array}{c}\text { Explratlo } \\
n \text { Date }\end{array}$ & Status \\
\hline 0086029 & NJPDES Groundwater & $4 / 1 / 89$ & $12 / 31 / 94$ & $\begin{array}{l}\text { In compliance. Adjudicatory } \\
\text { hearing pending in relation to } \\
\text { wells placed at B-site. }\end{array}$ \\
\hline 0023922 & $\begin{array}{c}\text { NJPDES Surface } \\
\text { water }\end{array}$ & $9 / 28 / 84$ & $10 / 31 / 89$ & $\begin{array}{l}\text { In compliance. Awaiting } \\
\text { NJDEPE approval of new } \\
\text { permit. Nov } 92 \text { two non- } \\
\text { compliances: COD, } 54 \text { mg/l; } \\
\text { TSS } 140 \text { mg/l. Cause still } \\
\text { under investigation; no non- } \\
\text { compliances since Nov. DEPE } \\
\text { inspection } 3 / 1 / 93 \text {. notice of } \\
\text { violation for Nov. } 92 \text { TSS non- } \\
\text { compliance; no tine assigned. }\end{array}$ \\
\hline 092187 & TFTR Dlesel Exhaust & $10 / 24 / 89$ & $10 / 24 / 94$ & $\begin{array}{l}\text { Current. } \\
\text { NJ Air Plant Id. No. } 15952 .\end{array}$ \\
\hline 096074 & C site Diesel Exhaust & $6 / 28 / 90$ & $6 / 28 / 95$ & Current. \\
\hline 094831 & $\begin{array}{l}\text { Hot Cell Degreaser } \\
\text { Vent }\end{array}$ & $3 / 30 / 90$ & $6 / 16 / 97$ & Current. \\
\hline 090735 & $\begin{array}{l}\text { FCPC Building } \\
\text { Degreaser Vent }\end{array}$ & $6 / 6 / 89$ & $5 / 31 / 95$ & Current. \\
\hline 826 & $\begin{array}{l}\text { Elizabethtown Water } \\
\text { Physical Connection }\end{array}$ & $4 / 1 / 91$ & $3 / 31 / 93$ & $\begin{array}{l}\text { Renewal forms and tee } \\
\text { submitted to DOE/PAO } \\
5 / 4 / 93 \text {. }\end{array}$ \\
\hline 148539 & UST Registration & $4 / 1 / 92$ & $3 / 31 / 93$ & $\begin{array}{l}\text { Recelved invoice on } 5 / 17 / 93 \\
\text { for UST registration renewal. }\end{array}$ \\
\hline 089962 & Diesel Tank E8 Vent & 11/22/88 & $11 / 22 / 93$ & Current. \\
\hline 061295 & Boller \#2 Stack Vent & $3 / 31 / 82$ & $3 / 31 / 97$ & Current. \\
\hline 061296 & Boiler \#3 Stack Vent & $3 / 31 / 82$ & $3 / 31 / 97$ & Current. \\
\hline 061297 & Boiler \#4 Stack Vent & $3 / 31 / 82$ & $3 / 31 / 97$ & Current. \\
\hline 061299 & Boiler \#5 Stack Vent & $3 / 31 / 82$ & $3 / 31 / 97$ & Current. \\
\hline 061298 & $\begin{array}{c}\text { Oil Storage Tank Vent } \\
\text { No. } 2\end{array}$ & $3 / 31 / 82$ & $3 / 31 / 97$ & $\begin{array}{l}\text { Current. Received permit: } \\
\text { change from } \# 6 \text { to } \# 4 \text { oil, } \\
\text { approval date } 3 / 3 / 93 \text {. }\end{array}$ \\
\hline 0128306 & $\begin{array}{l}\text { Medical Waste } \\
\text { Generator }\end{array}$ & $7 / 22 / 91$ & $7 / 21 / 93$ & Current. \\
\hline DR-18A & $\begin{array}{l}\text { D\&R Canal Water Use } \\
\text { Aareement }\end{array}$ & $7 / 1 / 84$ & $6 / 30 / 2009$ & Current. \\
\hline 12471 & $\begin{array}{l}\text { REML Laboratory } \\
\text { Centification }\end{array}$ & $7 / 1 / 91$ & $6 / 30 / 93$ & Current. \\
\hline 111580 & CAS Dust Collector & $3 / 10 / 93$ & $3 / 10 / 98$ & New Air Certificate. \\
\hline $92-7082-4 N$ & TWA Detention Basin & $2 / 26 / 93$ & $2 / 25 / 95$ & New Construction permit \\
\hline
\end{tabular}


Table 15. Summary of 1992 Emissions and Doses from TFTR

\begin{tabular}{|c|c|c|c|c|}
\hline $\begin{array}{l}\text { RADTO- } \\
\text { NUCLIDE \& } \\
\text { PATHWAY } \\
\end{array}$ & $\begin{array}{l}\text { QUANTITY } \\
\text { RELEASED IN } \\
19921\end{array}$ & $\begin{array}{l}\text { EDE AT THE } \\
\text { SITE BOUNDARY }\end{array}$ & $\begin{array}{l}\text { EDE AT THE } \\
\text { NEAREST } \\
\text { BUSINESS } 2 \\
\end{array}$ & $\begin{array}{l}\text { POPULATION } \\
\text { DOSE WITHIN } \\
80 \mathrm{KM}^{3} \\
\end{array}$ \\
\hline $\begin{array}{l}\text { Trlllum (HTO) } \\
\text { (alr) }\end{array}$ & $0.967 \mathrm{Cl}^{4}$ & $2.5 \times 10^{-3} \mathrm{mrem}^{5}$ & $7 \times 10^{-4} \mathrm{mrem}^{6}$ & $\begin{array}{l}3.1 \times 10^{-2} \text { person- } \\
\text { rem } 7\end{array}$ \\
\hline Ar-41 (alr) & $1.649 \mathrm{CH}^{4}$ & $6.6 \times 10^{-3} \mathrm{mrem}^{8}$ & $1.8 \times 10^{-3} \mathrm{mrem}^{6}$ & $\begin{array}{l}9.6 \times 10^{-3} \text { person- } \\
\text { rem } 9\end{array}$ \\
\hline $\begin{array}{l}\text { Direct } 8 \\
\text { Scattored } \\
\text { Noutrons and } \\
\text { Gamma } \\
\text { Radlation } \\
\end{array}$ & & $1 \times 10^{-2} \mathrm{mrem}^{10}$ & $2.5 \times 10^{-3} \mathrm{mrem}^{11}$ & Negligible \\
\hline $\begin{array}{l}\text { Tritlum (HTO) } \\
\text { (water) }\end{array}$ & $1.6 \times 10^{-2} \mathrm{Cl}^{12}$ & $3.2 \times 10^{-4} \mathrm{mrem}^{13}$ & & $\begin{array}{l}4.4 \times 10^{-4} \text { person- } \\
\operatorname{rem}^{14}\end{array}$ \\
\hline Total & & $1.9 \times 10^{-2} \mathrm{mrem}$ & $5 \times 10^{-3}$ mrem & $\begin{array}{l}4.1 \times 10^{-2} \text { person- } \\
\text { rem }\end{array}$ \\
\hline Background & & 600 mrem $^{15}$ & 600 mrem 15 & $\begin{array}{l}1.6 \times 10^{6} \text { person- } \\
\text { rem }\end{array}$ \\
\hline
\end{tabular}

${ }^{1}$ Tritium \& ${ }^{41}$ Ar quantitios are based on production of $2.005 \times 10^{19}$ D-D neutrons in 1992.

2 At Princeton Bank Building, 351 meters east of TFTR stack.

3Based on year 1995 population figures as utilized for TFTR D-T EA. See Table 4 of Bentz and Bender, 1987.

${ }^{4}$ As per PPPL memoranda, D. Jassby to J. Gilbert, 2/10/92 and 1/12/93.

5 Based on NOAA XO [Start, 1989]; $0.967 \mathrm{CI} \times 2.6 \times 10^{-3} \mathrm{mrem} / \mathrm{Ci}$.

${ }^{6}$ Based on $28 \%$ of the NOAA XO at the site boundary [Start, 1989].

7 Scaling trom values used for the TFTR D-T EA, we get (0.967 Ciso0 Ci) $\times 16.2$ person-rem $=3.1 \times 10^{-2}$ person-rem.

${ }^{8}$ Based on NOAA XO [Stant, 1989]; $1.649 \mathrm{Cl} \times 4.0 \times 10^{-3} \mathrm{mrem} / \mathrm{Ci}$.

9Scaling from values used for the TFTR D-T EA, we get $(1.649 \mathrm{CV} / 15 \mathrm{Ci}) \times 0.67$ person-rem $=9.6 \times 10^{-3}$ person-rem.

10 Based on $5 \times 10^{-22}$ mrem/D-D neutron as per TFTR-FSAR Amendment No. 2, Section 4.9.4.

${ }^{11}$ Based on inverse square decrease between site boundary (176 meters) and nearest business (351 meters).

12Released from Liquid Effluent Collection Tanks (LECT) to Stony Brook Sewer Authority treatment facility via PPPL sanitary sewer system.

13 Based on usage of $1 \times 10^{10}$ liters/yr for Stony Brook treatment facility, as per TFTR D-T EA, the dose to a person who drank all hisher water from the watenway (Millstone River) into which the treatment facility discharged in 1992 would be $\left[\left(1.6 \times 10^{-2} \mathrm{C}(\mathrm{yr})\left(11 \times 10^{10} \mathrm{(yr}\right)\right] \times\left[(4 \mathrm{mrern}) /\left(2 \times 10^{-8} \mathrm{Ci} / \mathrm{h}\right)\right]=3.2 \times 10^{-4} \mathrm{mrem}\right.$. 14 Based on use of Millstone River as drinking water source fer 500,000 people for 1 day per year (estimate by
Elizabethtown Water Company of actual use is a few hours once every several years).

15 Based on 100 mrem annual background dose exclusive of radon, plus dose due to exposure to average radon concentration in Piainsboro homes (Memo, J. Greco to J. Levine, 11/13/90, "Radon Dose Equivalent," JMG-160). 
Table 16. Tritium in Precipitation at PPPL for 1992

\begin{tabular}{|c|c|c|}
\hline Precipltation Collection Dates & Perlod & Tritlum Concentration (pCi/l) \\
\hline $1 / 1 / 92$ & 1 & No Sample \\
\hline $1 / 6 / 92$ & 2 & No Sample \\
\hline $1 / 13 / 92$ & $\overline{3}$ & 42.5 \\
\hline $1 / 20 / 92$ & 4 & 19.2 \\
\hline $1 / 27 / 92$ & 5 & 7.9 \\
\hline $2 / 3 / 92$ & 6 & No Sample \\
\hline $2 / 10 / 92$ & 7 & 47 \\
\hline $2 / 17 / 92$ & 8 & 33 \\
\hline $2 / 24 / 92$ & $\overline{9}$ & No Sample \\
\hline $3 / 2 / 92$ & 10 & 35.4 \\
\hline $3 / 9 / 92$ & 11 & 19.4 \\
\hline $3 / 16 / 92$ & 12 & 18.6 \\
\hline $3 / 23 / 92$ & 13 & 45.4 \\
\hline $3 / 30 / 92$ & 14 & 25.7 \\
\hline $4 / 6 / 92$ & 15 & No Sample \\
\hline $4 / 13 / 92$ & 16 & No Sample \\
\hline $4 / 20 / 92$ & 17 & 25.8 \\
\hline $4 / 27 / 92$ & 18 & 32.2 \\
\hline $5 / 4 / 92$ & 19 & No Sample \\
\hline $5 / 11 / 92$ & 20 & 26.5 \\
\hline $5 / 18 / 92$ & 21 & 41.6 \\
\hline $5 / 25 / 92$ & 22 & 73.1 \\
\hline 6/1/92 & 23 & 26.4 \\
\hline $6 / 8 / 92$ & 24 & 28.4 \\
\hline $6 / 15 / 92$ & 25 & No Sample \\
\hline $6 / 22 / 92$ & 26 & 55.4 \\
\hline $6 / 29 / 92$ & 27 & 83.8 \\
\hline $7 / 6 / 92$ & 28 & 49.9 \\
\hline $7 / 13 / 92$ & 29 & 14.2 \\
\hline $7 / 20 / 92$ & 30 & 53.2 \\
\hline $7 / 27 / 92$ & 31 & 54.4 \\
\hline $8 / 3 / 92$ & 32 & 61.1 \\
\hline $8 / 10 / 92$ & 33 & No Precipitation \\
\hline $8 / 17 / 92$ & 34 & 46.9 \\
\hline $8 / 24 / 92$ & 35 & No Sample \\
\hline $8 / 27 / 92$ & 36 & 5.5 \\
\hline $9 / 7 / 92$ & 37 & 35.9 \\
\hline $9 / 14 / 92$ & 38 & No Sample \\
\hline $9 / 21 / 92$ & 39 & 22.5 \\
\hline $9 / 28 / 92$ & 40 & 47.8 \\
\hline $10 / 5 / 92$ & 41 & 19.1 \\
\hline $10 / 12 / 92$ & 42 & 19.3 \\
\hline $10 /: 9 / 92$ & 43 & 11.8 \\
\hline $10 / 26 / 92$ & 44 & No Sample \\
\hline $11 / 2 / 92$ & 45 & No Sample \\
\hline $11 / 9 / 92$ & 46 & 14 \\
\hline $11 / 16 / 92$ & 47 & 17.1 \\
\hline $11 / 23 / 92$ & 48 & No Sample \\
\hline $11 / 30 / 92$ & 49 & No Sample \\
\hline $12 / 7 / 92,12 / 14 / 92$ & 50,51 & No Sample \\
\hline $12 / 21 / 92,12 / 28 / 92$ & 52,53 & No Sample \\
\hline
\end{tabular}


Table 17. Preolpltation at PPPL for 1992

\begin{tabular}{|c|c|c|c|c|c|}
\hline DATE & WEEK & INCH & INCH/MONTH & MONTH & ACCUMULATION \\
\hline $1 / 1 / 92$ & 1 & $\overline{0.675}$ & & & 0.675 \\
\hline $1 / 6 / 92$ & 2 & 0.240 & & & 0.915 \\
\hline $1 / 13 / 92$ & 3 & 0.300 & & & 1.215 \\
\hline $1 / 20 / 92$ & 4 & 0.800 & & & 2.015 \\
\hline $1 / 27 / 92$ & 5 & 0.000 & 2.015 & JAN & 2.015 \\
\hline $2 / 3 / 92$ & 6 & 0.075 & & & 2.090 \\
\hline $2 / 10 / 92$ & 7 & 0.800 & & & 2.890 \\
\hline $2 / 17 / 92$ & 8 & 0.125 & & & 3.015 \\
\hline $2 / 24 / 92$ & 9 & 0.550 & 1.550 & FEB & 3.565 \\
\hline $3 / 2 / 92$ & 10 & 0.675 & & & 4.240 \\
\hline $3 / 9 / 92$ & 11 & 0.550 & & & 4.790 \\
\hline $3 / 16 / 92$ & 12 & 0.800 & & & 5.590 \\
\hline $3 / 23 / 92$ & 13 & 0.690 & & & 6.280 \\
\hline $3 / 30 / 92$ & 14 & 0.350 & 3.065 & MAR & 6.630 \\
\hline $4 / 6 / 92$ & 15 & 0.300 & & & 6.930 \\
\hline $4 / 13 / 92$ & $\overline{16}$ & 0.950 & & & 7.880 \\
\hline $4 / 20 / 92$ & 17 & 0.270 & & & 8.150 \\
\hline $4 / 27 / 92$ & 18 & 0.050 & 1.570 & APA & 8.200 \\
\hline $5 / 4 / 92$ & 19 & 0.850 & & & 9.050 \\
\hline $5 / 11 / 92$ & 20 & 0.570 & & & 9.620 \\
\hline $5 / 18 / 92$ & 21 & 0.175 & & & 9.795 \\
\hline $5 / 25 / 92$ & 22 & 1.650 & 3.245 & $\overline{\text { MAY }}$ & 11.445 \\
\hline $6 / 1 / 92$ & 23 & 2.425 & & & 13.870 \\
\hline $6 / 8 / 92$ & 24 & 0.000 & & & 13.870 \\
\hline $6 / 15 / 92$ & 25 & 2.250 & & & 16.120 \\
\hline $6 / 22 / 92$ & 26 & 0.150 & & & 16.270 \\
\hline $6 / 29 / 92$ & 27 & 0.550 & 5.375 & JUN & 16.820 \\
\hline $7 / 6 / 92$ & 28 & 0.650 & & & 17.470 \\
\hline $7 / 13 / 92$ & 29 & 0.815 & & & 18.285 \\
\hline $7 / 20 / 92$ & 30 & 0.850 & & & 19.135 \\
\hline $7 / 27 / 92$ & 31 & 1.550 & 3.865 & JUL & 20.685 \\
\hline $8 / 3 / 92$ & 32 & 0.450 & & & 21.135 \\
\hline $8 / 10 / 92$ & 33 & 1.800 & & & 22.935 \\
\hline $8 / 17 / 92$ & 34 & 0.500 & & & 23.435 \\
\hline $8 / 24 / 92$ & 35 & 1.650 & & & 25.085 \\
\hline $8 / 27 / 92$ & 36 & 0.200 & 4.600 & AUG & 25.285 \\
\hline $9 / 7 / 92$ & 37 & 0.600 & & & 25.885 \\
\hline $9 / 14 / 92$ & 38 & 0.250 & & & 26.135 \\
\hline $9 / 21 / 92$ & 39 & 1.950 & & & 28.085 \\
\hline $9 / 28 / 92$ & 40 & 0.000 & 2.800 & SEP & 28.085 \\
\hline $10 / 5 / 92$ & 41 & 0.925 & & & 29.010 \\
\hline $10 / 12 / 92$ & 42 & 0.075 & & & 29.085 \\
\hline $10 / 19 / 92$ & 43 & 0.250 & & & 29.335 \\
\hline $10 / 26 / 92$ & 44 & 0.200 & 1.450 & OCT & 29.535 \\
\hline $11 / 2 / 92$ & 45 & 2.300 & & & 31.235 \\
\hline $11 / 9 / 92$ & 46 & 0.500 & & & 32.335 \\
\hline $11 / 16 / 92$ & 47 & 1.850 & & & 34.185 \\
\hline $11 / 23 / 92$ & 48 & 0.800 & & & 34.985 \\
\hline $11 / 30 / 92$ & 49 & 0.275 & 5.725 & NOV & 35.260 \\
\hline $12 / 7 / 92$ & 50 & 5.300 & & & 40.560 \\
\hline $12 / 14 / 92$ & 51 & 1.050 & & & 41.610 \\
\hline $12 / 21,28 / 32$ & 52,53 & $0.000,0.250$ & 6.600 & $\overline{D E C}$ & $41.610,41.860$ \\
\hline
\end{tabular}


Table 18. Tritium Concentrations in Surface Water for 1992

\begin{tabular}{|c|c|c|c|c|c|c|}
\hline Cowrection & By? & EP? & का & (B) & DQ2 & BPSerime \\
\hline January & 35.83 & 33.17 & 32.59 & 38.14 & 43.81 & None \\
\hline February & 41.88 & 44.53 & 42.01 & 49.93 & 44.19 & None \\
\hline March & 41.15 & 40.14 & 47.29 & 41.23 & 39.77 & None \\
\hline April & 32.44 & 47.95 & 44.03 & 45.72 & 49.54 & 55.57 \\
\hline May & 32.16 & 36.72 & 46.21 & 39.07 & 39.1 & 49.73 \\
\hline June & 41.38 & 48.19 & 25.79 & 20.4 & 38.53 & 34.26 \\
\hline July & 43.04 & 54.35 & 62.8 & 82.74 & 61.11 & 53.58 \\
\hline August & 41.09 & 39.92 & 46.11 & 34.46 & 46.89 & 36.84 \\
\hline September & 16.39 & 40.59 & 23.67 & 43.42 & 37.57 & 37.15 \\
\hline October & None & None & None & None & None & None \\
\hline November & 58.33 & 40.49 & 36.41 & 33.59 & 39.37 & 23.4 \\
\hline December & None & None & None & None & None & None \\
\hline
\end{tabular}

\begin{tabular}{|c|c|c|c|c|}
\hline 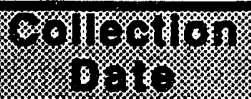 & ETI & Yrom & Pा? & Pश2? \\
\hline January & 49.45 & 35.15 & 42.66 & 39.58 \\
\hline February & 42.09 & 26.1 & 45.44 & 29.76 \\
\hline March & 51.6 & 42.76 & 51.47 & 48.02 \\
\hline April & 39.28 & 44 & 50.54 & 54.34 \\
\hline May & 42.79 & 46.62 & 29.76 & 46.35 \\
\hline June & 36.63 & 32.15 & 40.69 & 30.4 \\
\hline July & 76.7 & 47.16 & 60.61 & 44.04 \\
\hline August & 35.2 & 63.81 & 53.98 & 33.59 \\
\hline September & 35.33 & 39.61 & 42.12 & 30.55 \\
\hline October & None & None & None & None \\
\hline November & 41.8 & None & 32.93 & 26.57 \\
\hline December & None & 12.46 & None & None \\
\hline
\end{tabular}

*All measurement values are in $\mathrm{pCi} /$ Liter.

Table 19. Tritium Concentrations in Groundwater for 1992

\begin{tabular}{|c|c|c|c|c|c|c|c|}
\hline 6.0I\%, & 8918 & प्रा12 & गW & 9670 & TWB & W4: & W5: \\
\hline February & & & 36.14 & 41.35 & & & \\
\hline May & 41.63 & 42.61 & 37.74 & 55.72 & 41.74 & 32.33 & 31.51 \\
\hline August & 44.03 & 23.73 & & & 31.68 & & 33.9 \\
\hline
\end{tabular}

*All measurement values are in $\mathrm{PCi} / \mathrm{Liter}$. 
Table 20. Tritium Concentrations in Soil/Sod for 1992

\begin{tabular}{|c|c|c|c|c|c|c|c|}
\hline March, 1992 & 45.58 & 37.94 & 45.61 & 38.92 & 48.99 & 53.44 & None \\
\hline June, 1992 & 76.21 & 68.43 & 69.42 & 65.14 & 69.96 & 74.93 & 59.14 \\
\hline August, 1992 & None & 52.07 & 33.27 & 61.47 & None & None & None \\
\hline October, 1992 & 34.66 & 30.97 & 15.37 & 15.37 & 13.79 & 14.21 & 29.38 \\
\hline
\end{tabular}

-All measurement values are in pCiliter.

Table 21. Tritium Concentrations in Biota Moisture for 1992

\begin{tabular}{|c|c|c|c|c|c|}
\hline काrection & $8.6 \%$ & Poreas & Primprin & RiaspherTy & Tromatoes \\
\hline June & & 35.22 & & & \\
\hline September & 39.74 & & 33.12 & 38.96 & 48.83 \\
\hline
\end{tabular}

*All measurement values are in $\mathrm{PCi} / \mathrm{Liter}$. 
Table 22. 1992 Surface Water Analysis for Bee Brook, Locations B1 and B2

\begin{tabular}{|c|c|c|c|c|}
\hline How & 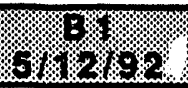 & 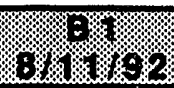 & 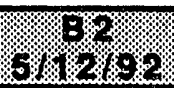 & arorar \\
\hline Chromium, mgl & $<0.01$ & $<0.01$ & $<0.01$ & $<0.01$ \\
\hline $\mathrm{pH}$, units & 7.15 & 7.00 & 7.05 & 7.25 \\
\hline Phenolics as phenol, mg/1 & $<0.10$ & $<0.10$ & 0.10 & $<0.10$ \\
\hline Chemical Oxygen Demand, $\mathrm{mg} / 1$ & 22 & 33 & $<20.0$ & 24 \\
\hline $\begin{array}{l}\text { Biochemical Oxygen Demand, 5- } \\
\text { day total, } \mathrm{mg} / 1\end{array}$ & $<4.0$ & $<4.0$ & 4.3 & $<4.0$ \\
\hline Temperature, ${ }^{\circ} \mathrm{C}$ & 12 & 21 & 14 & 23 \\
\hline $\begin{array}{l}\text { Petroleum Hydrocarbons by IR, } \\
\text { mg/1 }\end{array}$ & $<1.0$ & $<1.0$ & $<1.0$ & $<1.0$ \\
\hline Ammonia-N, mg/1 & $<0.50$ & $<0.50$ & $<0.50$ & $<0.50$ \\
\hline Total Suspended Solids, mg/1 & 7.9 & 9.0 & $<5.0$ & 19.0 \\
\hline Total Dissolved Solids, $\mathrm{mg} / 1$ & 280.0 & 220.0 & 190.0 & 280.0 \\
\hline Fluw, Approximate GPM & 157.09 & 34.99 & $1,047.27$ & 675 \\
\hline
\end{tabular}

Table 23. 1992 Surface Water Analysis
for D\&R Canal, C1, and Ditch \#5, D1

\begin{tabular}{|c|c|c|c|c|}
\hline 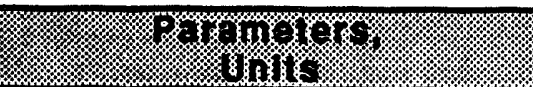 & (1) & $8 \times 1 \times 1 \% 2$ & (1) & 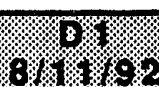 \\
\hline Chromium, mg/l & & & $<0.01$ & $<0.01$ \\
\hline pH, units & 7.00 & 7.06 & 7.80 & 6.91 \\
\hline Phenolics as phenol, $\mathrm{mg} / 1$ & $<0.10$ & $<0.10$ & $<0.10$ & $<0.10$ \\
\hline Chemical Oxygen Demand, mg/1 & 25.0 & $<20.0$ & $<20.0$ & 24.0 \\
\hline $\begin{array}{l}\text { Biochemical Oxygen Demand, 5- } \\
\text { day total, } \mathrm{mg} / 1\end{array}$ & $<4.0$ & $<4.0$ & $=4.0$ & $<4.0$ \\
\hline Temperature, ${ }^{\circ} \mathrm{C}$ & & 25 & 16 & 25 \\
\hline $\begin{array}{l}\text { Petroleum Hydrocarbons by IR, } \\
\text { mg/1 }\end{array}$ & $<1.0$ & $<1.0$ & $<1.0$ & $<1.0$ \\
\hline Ammonia- $\mathrm{N}, \mathrm{mg} / 1$ & $<0.50$ & $<0.50$ & $<0.50$ & $<0.50$ \\
\hline Total Suspended Solids, mg/1 & 8.4 & 8.0 & $<5.0$ & $<5.0$ \\
\hline Total Dissolved Solids, $\mathrm{mg} / 1$ & 92 & 110.0 & 96.0 & 100.0 \\
\hline Flow, Approximate GPM & & & 527.82 & 344.70 \\
\hline
\end{tabular}

Blank indicates no measurement.

- Not available due to equipment problem 
Table 24. 1992 Surface Water Analysis for Potable Water Supply, E1, and Millstone River, M1

\begin{tabular}{|c|c|c|c|c|}
\hline \%rromers & . & 3. & 5. & 6.161 .02 \\
\hline $\mathrm{pH}$, units & 7.30 & 6.85 & 7.40 & 6.96 \\
\hline Phenolics as phenol, $\mathrm{mg} / 1$ & $<0.10$ & $<0.10$ & $<0.10$ & $<0.10$ \\
\hline Chemical Oxygen Demand, $\mathrm{mg} / 1$ & $<20.0$ & $<20.0$ & $<20.0$ & $<20.0$ \\
\hline $\begin{array}{l}\text { Biochemical Oxygen Demand, 5-day total, } \\
\text { mg/1 }\end{array}$ & $\leq 4.0$ & $<4.0$ & 4.3 & $<4.0$ \\
\hline Temperature, ${ }^{\circ} \mathrm{C}$ & 15 & 20 & & 26 \\
\hline Petroleum Hydrocarbons by $/ \mathrm{R}, \mathrm{mg} / \mathrm{t}$ & $<1.0$ & $<1.0$ & $<1.0$ & $<1.0$ \\
\hline Ammonia-N, mg/1 & $<0.50$ & $<0.50$ & $<0.50$ & $<0.50$ \\
\hline Total Suspended Solids, mg/1 & $<5.0$ & $<5.0$ & 13.0 & 8.0 \\
\hline Total Dissolved Solids, mg/1 & 180.0 & 220.0 & 130.0 & 120.0 \\
\hline
\end{tabular}

Table 25. 1992 Surface Water Analysis for Plainsboro, Locations P1 and P2

\begin{tabular}{|c|c|c|c|c|}
\hline PY9morr: & (j) & $8.9 .1 \%$ & 5.1\%: & 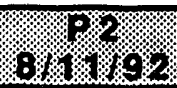 \\
\hline $\mathrm{pH}$, units & 6.90 & 6.45 & 6.90 & 6.50 \\
\hline Phenolics as phenol, $\mathrm{mg} / 1$ & $<0.10$ & $<0.10$ & $<0.10$ & $<0.10$ \\
\hline Chemical Oxygen Demand, mg/1 & 22.0 & $<20.0$ & $<20.0$ & $<20.0$ \\
\hline $\begin{array}{l}\text { Biochemical Oxygen Demand, 5-day total, } \\
\text { mg/1 }\end{array}$ & 4.7 & $<4.0$ & 5.8 & $<4.0$ \\
\hline Temperature, ${ }^{\circ} \mathrm{C}$ & $\cdots$ & 20 & & 23 \\
\hline Petroleum Hydrocarbons by $\mid \mathrm{R}, \mathrm{mg} / 1$ & $<1.0$ & $<1.0$ & $<1.0$ & $<1.0$ \\
\hline Ammonia- $\mathrm{N}, \mathrm{mg} / \mathrm{1}$ & $<0.50$ & $<0.50$ & $<0.50$ & $<0.50$ \\
\hline Total Suspended Solids, mg/1 & $<5.0$ & $<5.0$ & 15.0 & 74.0 \\
\hline Total Dissolved Solids, mg/1 & 74.0 & 89.0 & 110.0 & 92.0 \\
\hline
\end{tabular}

Table 26. 1992 Detention Basin Influents Analysis (NJDPES)

\begin{tabular}{|c|c|c|c|c|}
\hline \% $14 \ln 19 \%$ & WTor & migros & 25intory & $28 \% 1 \%$ \\
\hline $\mathrm{pH}$, units & 6.50 & 7.04 & 6.80 & 7.15 \\
\hline Phenolics as phenol, $\mathrm{mg} / 1$ & $<0.10$ & $<0.10$ & $<0.10$ & $<0.10$ \\
\hline Chemical Oxygen Demand, mg/1 & $<20.0$ & $<20.0$ & $<20.0$ & $<20.0$ \\
\hline $\begin{array}{l}\text { Biochemical Oxygen Demand, 5-day total, } \\
\text { mg/1 }\end{array}$ & 17 & $<4.0$ & 13 & $<4.0$ \\
\hline Petroleum Hydrocarbons by IR, $\mathrm{mg} / 1$ & $<1.0$ & & $<1.0$ & \\
\hline Ammonia- $\mathrm{N}, \mathrm{mg} / 1$ & $<0.50$ & $<0.50$ & $<0.50$ & $<0.50$ \\
\hline Settleable Solids, \% & $<0.01$ & 0.01 & $<0.01$ & $<0.01$ \\
\hline Total Dissolved Solids, mg/1 & & 120.0 & & 230.0 \\
\hline Total Suspended Solids, mg/1 & 160 & & $<5.0$ & \\
\hline Chromium, mg/l & $<0.01$ & $<0.01$ & $<0.01$ & $<0.01$ \\
\hline
\end{tabular}

Blank indicates no measurement.

" Not available due to equipment problem. 
Table 27. 1992 Monthly Surface Water Analysis for Ditch \#5, Location D2 (NJPDES-DSN 001A).

\begin{tabular}{|c|c|c|c|c|c|c|c|c|}
\hline ; & 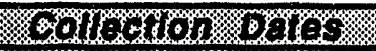 & 1/6\% & 3/1/ & $8 \% 10$ & \%\$ & $3 \%$ & WW & \% \\
\hline \% & Pror & & & & & & & \\
\hline NA & Chromium total, mg/1 & $<0.01$ & $<0.01$ & $<0.01$ & $<0.01$ & $<0.01$ & 0.02 & $<0.01$ \\
\hline $6.0-9.0$ & $\mathrm{pH}$, units & 7.50 & 8.10 & 7.10 & 7.10 & 7.46 & 7.23 & 6.89 \\
\hline NA & $\begin{array}{c}\text { Phenolics Phenol, } \\
\text { mg/1 }\end{array}$ & $<0.1$ & $<0.1$ & $<0.1$ & $<0.1$ & $<0.1$ & $<0.1$ & 0.1 \\
\hline $50 \mathrm{mg} / \mathrm{l}$ & $\begin{array}{l}\text { Chemical Oxygen } \\
\text { Demand, mg/1 }\end{array}$ & $<20$ & $<20$ & $66^{*}$ & $<20$ & $<20$ & 34 & 40 \\
\hline NA & $\begin{array}{c}\text { Biochemical Oxygen } \\
\text { Demand, 5-day total, } \\
\text { mg/1 }\end{array}$ & $<4.0$ & 8.8 & $<4.0$ & $<4.0$ & 4.5 & 14.0 & 5.8 \\
\hline $10 \mathrm{mg} / \mathrm{l}$ & $\begin{array}{c}\text { Petroleum } \\
\text { Hydrocarbons by IR, } \\
\text { mg/1 }\end{array}$ & $<1$ & $<1$ & $<1$ & $<1$ & $<1$ & $<1$ & $<1$ \\
\hline NA & Ammonia-N, mg/1 & $<0.5$ & $<0.5$ & $<0.5$ & $<0.5$ & $<0.5$ & $<0.5$ & $<0.5$ \\
\hline $50 \mathrm{mg} / 1$ & $\begin{array}{l}\text { Total Suspended } \\
\text { Solids, mg/1 }\end{array}$ & $<5.0$ & 17.0 & 5.0 & $<5.0$ & 9.0 & 13.0 & 18.0 \\
\hline NA & $\begin{array}{c}\text { Total Dissolved Solids, } \\
\mathrm{mg} / 1\end{array}$ & 280 & 160 & 150 & 170 & 160 & 78 & 150 \\
\hline $\begin{array}{l}30^{\circ} \mathrm{C} \\
\max .\end{array}$ & Temperature ${ }^{\circ} \mathrm{C}$ & 10 & 11 & 11 & 12 & $\overline{14}$ & 17 & 19 \\
\hline NA & Flow, GPM & 8,700 & 4,818 & 5,801 & 7,923 & 5,671 & 10,156 & 2,059 \\
\hline
\end{tabular}

\begin{tabular}{|c|c|c|c|c|c|c|c|c|}
\hline 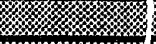 & 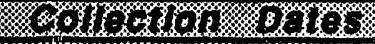 & \%1\%:\% & \%OK\% & \%OB & Wow & \%1\%180 & $182 \% 8$ & WKo \\
\hline r. & Sont & & & & & & & \\
\hline NA & Chromium total, $\mathrm{mg} / 1$ & $<0.01$ & $<0.01$ & $<0.01$ & $<0.01$ & 0.010 & $<0.01$ & $<0.01$ \\
\hline $6.0-9.0$ & $\mathrm{pH}$, units & 7.55 & 7.03 & 6.72 & 7.35 & 7.10 & 7.40 & 7.40 \\
\hline NA & $\begin{array}{c}\text { Phenolics Phenol, } \\
\text { mg/1 }\end{array}$ & $<0.1$ & $<0.1$ & $<0.1$ & $<0.1$ & $<0.1$ & $<0.05$ & $<0.05$ \\
\hline $50 \mathrm{mg} / \mathrm{l}$ & $\begin{array}{l}\text { Chemical Oxygen } \\
\text { Demand, mg/1 }\end{array}$ & 40 & $<20$ & $<20$ & $<20$ & $54^{\star}$ & $<20$ & $<20$ \\
\hline NA & $\begin{array}{c}\text { Biochemical Oxygen } \\
\text { Demand, 5-day total, } \\
\text { mg/1 }\end{array}$ & $18 . C$ & $<4.0$ & $<4.0$ & 4.5 & 7.9 & $<4.0$ & $<4.0$ \\
\hline $10 \mathrm{mg} / \mathrm{l}$ & $\begin{array}{c}\text { Petroleum } \\
\text { Hydrocarbons by IR, } \\
\mathrm{mg} / 1\end{array}$ & $<1$ & $<1$ & $<1$ & $<1$ & $<1$ & $<1$ & $<1$ \\
\hline NA & Ammonia- $N$, mg/1 & $<0.5$ & $<0.5$ & $<0.5$ & $<0.5$ & $<0.5$ & $<0.5$ & $<0.5$ \\
\hline $50 \mathrm{mg} / \mathrm{l}$ & $\begin{array}{l}\text { Total Suspended } \\
\text { Solids, } \mathrm{mg} / 1 \\
\end{array}$ & 13.0 & 6.0 & 6.1 & 5.1 & $140^{*}$ & $<5.0$ & $<5.0$ \\
\hline NA & $\begin{array}{c}\text { Total Dissolved Solids, } \\
\mathrm{mg} / 1\end{array}$ & 270 & 350 & 230 & 150 & 260 & 100 & 110 \\
\hline $\begin{array}{l}30^{\circ} \mathrm{C} \\
\max .\end{array}$ & Temperature ${ }^{\circ} \mathrm{C}$ & 23 & 23 & 22 & $\overline{16}$ & 15 & 4 & 4 \\
\hline NA & Flow, GPM & 5,697 & 9,976 & 6,125 & 5,191 & 1,948 & 7,322 & \\
\hline
\end{tabular}

Blank indicates no measurement.

"Exceeded permit limit of $\mathbf{5 0 . 0}$ mg/l maximum daily limit 
Table 28. 1992 Release Reports

\begin{tabular}{|c|c|c|c|}
\hline 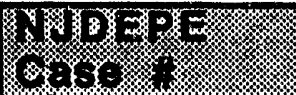 & $\operatorname{pog} 2$. & Titile & Thoe of Relerase \\
\hline $92-2-25-1927-24$ & ER92-01 & Capacitor Failure Incident & $\begin{array}{l}<1 \text { yallon of mineral oil on } \\
\text { concrete and/or around }\end{array}$ \\
\hline $92-4-1-1106-29$ & ER92-02 & Hydraulic Fluid in RF Courtyard) & $\begin{array}{l}2 \text { gallons of hydraulic fluid } \\
\text { on paved roadway ?nd } \\
\text { gravel area. }\end{array}$ \\
\hline $92-9-2-1502-49$ & ER92-03 & Excavation Oil Spill & $\begin{array}{l}<1 \text { quart of \#6 fuel onto } \\
\text { ground. }\end{array}$ \\
\hline
\end{tabular}

Table 29. Fertilizer, Pesticide, and Herbicide Application

\begin{tabular}{|c|c|}
\hline 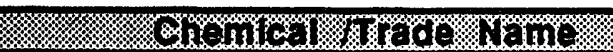 & $8 \mathrm{Bro}$ \\
\hline Surflan® & Herbicide \\
\hline Princep & Herbicide \\
\hline Roundup@ Herbicide & Herbicide \\
\hline Turf Food 25-3-9 Plus Team & Fertilizer \\
\hline 2 Plus 2 (MCPP +2,4-D Amine) & Pesticide \\
\hline PogmLOS & Torar atammes: \\
\hline Pyrid & 2 quarts \\
\hline Ficam Plus & 2.75 gallons \\
\hline Conquer & 0.5 gallons \\
\hline Seven Dust & 8 ounces \\
\hline Wasp Freeze & 29 ounces \\
\hline Maki Bait & 18 packs - 12 ounces each \\
\hline Drione Dust & 6 ounces \\
\hline Diazone & 6 ounces \\
\hline Tempo & 40 ounces \\
\hline Dursban Lo & 0.75 gallons \\
\hline Cynoff & 0.5 gallons \\
\hline
\end{tabular}


Table 30. 1992 Groundwater Elevations in the Underground Storage Tanks (UST) Moriltoring Wells

\begin{tabular}{|l|c|c|c|c|c|c|c|c|}
\hline January & 79.00 & 79.00 & 81.10 & 83.70 & 79.00 & 83.80 & 81.70 & 77.60 \\
\hline February & 82.50 & 82.30 & 83.70 & 85.50 & 82.80 & 85.50 & 83.80 & 80.20 \\
\hline March & 82.40 & 82.60 & 83.00 & 86.90 & 82.60 & 86.50 & 83.60 & 79.70 \\
\hline April & 83.00 & 83.20 & 84.40 & 88.70 & 83.30 & 86.40 & 84.90 & 80.30 \\
\hline May & 82.80 & 83.10 & 84.40 & 89.00 & 83.10 & 86.20 & 85.00 & 80.30 \\
\hline June & 85.20 & 85.50 & 86.40 & 88.80 & 85.50 & 86.60 & 86.40 & 82.20 \\
\hline July & 83.40 & 83.60 & 85.30 & 87.80 & 83.70 & 85.80 & 85.50 & 81.10 \\
\hline August & 84.50 & 84.64 & 85.14 & 87.21 & 84.61 & 85.70 & 85.30 & 82.04 \\
\hline September & 79.74 & 79.88 & 82.94 & 85.99 & 79.95 & 84.46 & 82.79 & 78.68 \\
\hline October & 79.24 & 79.38 & 82.49 & 85.10 & 79.45 & 84.37 & 82.92 & 77.62 \\
\hline November & 80.24 & 80.42 & 82.94 & 85.01 & 80.46 & 85.01 & 83.33 & 78.10 \\
\hline December & 89.72 & 89.93 & 88.18 & 90.83 & 89.92 & 87.31 & 88.11 & 85.77 \\
\hline Annual Avg & 82.65 & 82.80 & 84.17 & 87.05 & 82.87 & 85.64 & 84.45 & 80.30 \\
\hline
\end{tabular}

\begin{tabular}{|l|c|c|c|c|c|c|c|c|}
\hline January & 80.90 & 80.30 & 81.70 & 79.90 & 81.00 & 80.70 & 84.40 & 84.10 \\
\hline February & 83.10 & 82.90 & 83.60 & 81.50 & 82.20 & 82.80 & 85.30 & 85.30 \\
\hline March & 81.90 & 82.50 & 82.70 & 80.90 & 81.80 & 82.70 & 85.70 & 86.20 \\
\hline April & 83.10 & 83.40 & 84.00 & 81.70 & 82.70 & 83.50 & 85.20 & 86.00 \\
\hline May & 83.10 & 83.20 & 83.40 & 81.50 & 82.60 & 82.30 & 85.40 & 85.90 \\
\hline June & 86.00 & 85.20 & 85.90 & 83.20 & 84.50 & 85.20 & 85.30 & 87.10 \\
\hline July & 84.70 & 84.20 & 85.50 & 82.70 & 84.10 & 84.2 & 85.10 & 85.60 \\
\hline Auqust & 84.59 & 83.94 & 85.00 & 82.51 & 84.00 & 83.92 & 85.65 & 85.60 \\
\hline September & 82.47 & 81.99 & 84.59 & 81.67 & 82.76 & 82.13 & 84.00 & 84.48 \\
\hline October & 81.92 & 81.55 & 83.84 & 81.19 & 82.18 & 81.69 & 84.10 & 84.36 \\
\hline November & 82.41 & 82.08 & 83.90 & 81.35 & 82.31 & 82.16 & 84.74 & 84.83 \\
\hline December & 87.79 & 87.01 & 86.67 & 84.09 & 85.23 & 86.74 & 85.88 & 86.88 \\
\hline Annual Avg & 83.50 & 83.19 & 84.23 & 81.85 & 82.95 & 83.17 & 85.06 & 85.53 \\
\hline
\end{tabular}

Table 31. Ground Water Monitoring Well Clusters

\begin{tabular}{|c|c|c|c|}
\hline 桨 & Wew. & 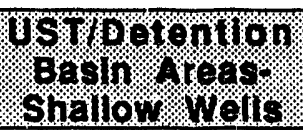 & 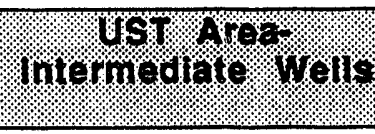 \\
\hline MW9 & UST1 & MW5S & MW7I \\
\hline MW13 & $P 1$ & MW8S & MW8I \\
\hline MW3 & MW2 & MW6S & MWGI \\
\hline MW1 & & P2 & MW4 \\
\hline & & MW7: & MW5I \\
\hline & & D11 & \\
\hline & & D12 & \\
\hline
\end{tabular}


Table 32. Undirground Storage Tank (UST) Monitoring Program Petrole um Hydrocarbon Results for 1992 (in $\mu \mathrm{g} / \mathrm{l}$ )

\begin{tabular}{|c|c|c|c|c|c|}
\hline 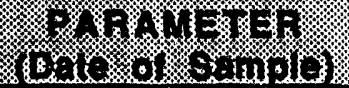 & 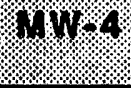 & $4 W=6 s$ & 411361 & $448 \% 8$ & 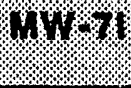 \\
\hline February & $<1000$ & $<1000$ & $<1000$ & $<1000$ & $<1000$ \\
\hline May & $<1000$ & $<1000$ & $<1000$ & $<1000$ & $<1000$ \\
\hline August & $<1000$ & $<1000$ & $<1000$ & $<1000$ & $<1000$ \\
\hline November & $<1000$ & & $<1000$ & $<1000$ & 1800 \\
\hline
\end{tabular}

\begin{tabular}{|c|c|c|c|c|c|}
\hline February & $<1000$ & $<1000$ & $<1000$ & $<1000$ & 1000 \\
\hline May & $<1000$ & $<1000$ & $<1000$ & $<1000$ & 1000 \\
\hline Auqust & $<1000$ & $<1000$ & $<1000$ & $<1000$ & 1000 \\
\hline November & $<1000$ & 1200 & $<1000$ & $<1000$ & 1000 \\
\hline
\end{tabular}


Table 33. Underground Storage Tank (UST) Monitoring Program Results - August 1992 (In $\mu \mathrm{g} / \mathrm{l})$

\begin{tabular}{|c|c|c|c|c|c|}
\hline 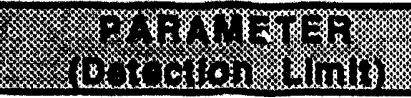 & arravar & 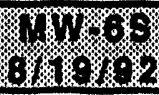 & 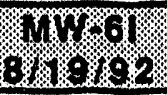 & sirists & $8 \%$ rover \\
\hline \multicolumn{6}{|l|}{ VOLATILE ORGANICS } \\
\hline 1,1-Dichloroethene (5) & & $4 \mathrm{JB}$ & & & \\
\hline 1,1-Dichloroethane (5) & & 9 & $2 J$ & & $\overline{6}$ \\
\hline $\begin{array}{l}\text { 1,2-Dichloroethene } \\
\text { (total)(5) }\end{array}$ & & $2 J$ & $2 J$ & & \\
\hline Chloroform (5) & & $3 J$ & & 10 & \\
\hline 1,1,1 Trichloroethane (5) & & 17 & & & \\
\hline Trichloroethene (5) & & $3 J$ & & & \\
\hline Benzene (5) & & & $3 \mathrm{~J}$ & & \\
\hline Tetrachloroethene (5) & & 15 & & 11 & $3 \mathrm{~J}$ \\
\hline Carbon Tetrachloride & & & & 7 & \\
\hline Non-Target Compounds & 10 & 0 & 18 & 0 & 17 \\
\hline
\end{tabular}

\begin{tabular}{|c|c|c|c|c|c|}
\hline 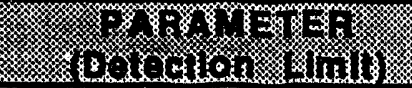 & 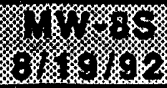 & 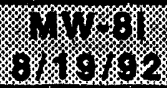 & Prank & צilan & \%ospe \\
\hline VOLATILE ORGANICS & & & $<5$ & $<5$ & \\
\hline 1,1-Dichloroethene (5) & & & & & 2 \\
\hline 1,1-Dichloroethane (5) & $\overline{7}$ & & $<5$ & $<5$ & 70 \\
\hline $\begin{array}{l}\text { 1,2-Dichloroethene } \\
\text { (tota) (5) }\end{array}$ & 33 & & $<5$ & $<5$ & 110 \\
\hline Chloroform (5) & 38 & & $<5$ & $<5$ & 6 \\
\hline 1,1,1 Trichloroethane (5) & $5 \mathrm{~J}$ & & & & 30 \\
\hline Trichloroethene (5) & 37 & & $<5$ & $<5$ & 1 \\
\hline Benzene (5) & & & & & 1 \\
\hline Tetrachloroethene (5) & 76 & & $<5$ & $<5$ & 1 \\
\hline Carbon Tetrachloride & & & $<5$ & $<5$ & 2 \\
\hline Non-Target Compounds & 0 & 0 & $<5$ & & 50 \\
\hline
\end{tabular}

$\mathrm{J}$ - Below the limits of reliable quantitation.

B - Detected in method blank also.

Blanks indicate that results were below the detection limit. 
Tables 34. 1992 Groundwater Analysis for Welle MW-14, MW-15, and MW-16

\begin{tabular}{|c|c|c|c|c|}
\hline$\gamma_{1}$ & Thx & WW:8 & WWro & Wros \\
\hline Chromium, mgh & & & $<0.025$ & $<0.025$ \\
\hline Lead, dissolvod, ma/l & & & $<0.005$ & $<0.005$ \\
\hline $\mathrm{pH}$, units & 5.30 & 5.40 & 5.60 & 7.00 \\
\hline Phenolics as phenol, mg/1 & & & $<0.1$ & $<0.1$ \\
\hline Nhtrate-N, mo/1 & & & 1.8 & 3.5 \\
\hline Total Organic Carbon, mg/1 & & & $<1$ & \\
\hline Total Organic Halides, mg & & & 99 & \\
\hline Potroleum Hydrocarbon by $/ \mathrm{R}, \mathrm{mg} / 1$ & & & $<1$ & \\
\hline Ammonia- $\mathrm{N}, \mathrm{mg} / \mathrm{9}$ & & $<0.5$ & $<0.5$ & $<0.5$ \\
\hline Chloride, mg/1 & & & 5.4 & 15 \\
\hline Total Dissolved Solids, mg/1 & 98 & 100 & 98 & 110 \\
\hline Sulfate, $\mathrm{mg} / 1$ & 15 & 1200 & 22 & 12 \\
\hline Conductivity, $\mu \mathrm{mhos} / \mathrm{cm}^{2}$ & 80 & 130 & 120 & 150 \\
\hline
\end{tabular}

\begin{tabular}{|c|c|c|c|c|}
\hline 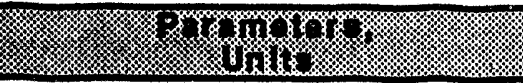 & צrm & \%xw & \%ros & Wros \\
\hline Chromium, mgh & & & $<0.025$ & $<0.025$ \\
\hline Lead, dissolved, mg/l & & & $<0.005$ & 0.0056 \\
\hline $\mathrm{pH}$, units & 5.90 & 6.00 & 5.60 & 6.90 \\
\hline Phenolics as phenol, mg/1 & & & $<0.1$ & $<0.1$ \\
\hline Nitrate-N, mg/1 & & & 1.1 & 0.95 \\
\hline Total Organic Carbon, $\mathrm{mg} / 1$ & & & $<1$ & \\
\hline Total Organic Halides, mgh & & & 29 & \\
\hline Potroloum Hydrocarbon by $\mid R, m g / 1$ & & & $<1$ & \\
\hline Ammonia-N, mg/1 & & $<0.5$ & $<0.5$ & $<0.5$ \\
\hline Chloride, $\mathrm{mg} / 1$ & & & $4^{\circ}$ & 4.9 \\
\hline Total Dissolved Solids, mg/1 & 89 & 92 & 92 & 76 \\
\hline Sulfate, $\mathrm{mg} / 1$ & 10 & 140 & 12 & 11 \\
\hline Conductivity, $\mu \mathrm{mhos} / \mathrm{cm}^{2}$ & 75 & 110 & $30^{*}$ & 130 \\
\hline
\end{tabular}

\begin{tabular}{|c|c|c|c|c|}
\hline 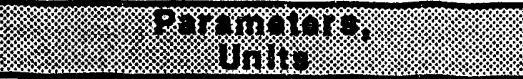 & myx: & WW & xw\% & Wron \\
\hline Chromium, mah & & & $<0.025$ & $<0.025$ \\
\hline Lead, dissolved, mg/l & & & $<0.005$ & $<0.005$ \\
\hline $\mathrm{pH}$, units & 7.00 & 6.60 & 6.40 & 7.40 \\
\hline Phenolics as phenol, $\mathrm{mg} / 1$ & & & $<0.1$ & $<0.1$ \\
\hline Nitrato-N, $\mathrm{mg} / 1$ & & & 0.23 & 0.83 \\
\hline Total Organic Carbon, mg/1 & & & 3.9 & \\
\hline Total Organic Halides, mg/ & & & 83 & \\
\hline Petroloum Hydrocarbon by IR, $\mathrm{mg} / 1$ & & & $<1$ & \\
\hline Ammonia-N, mg/1 & & $<0.5$ & $<0.5$ & $<0.5$ \\
\hline Chloride, mg/1 & & & 8.9 & 12 \\
\hline Total Dissolved Solids, $\mathrm{mg} / 1$ & 390 & 230 & 340 & 450 \\
\hline Sulfate, $\mathrm{mg} / 1$ & 87 & 140 & 33 & 99 \\
\hline Conductivity, $\mu \mathrm{mhos} / \mathrm{cm}^{2}$ & 460 & 390 & 580 & 510 \\
\hline
\end{tabular}

Blank indicates no measurement.

- Resampled on 9/8/92 
Table 35. 1992 Ground Water Analysis for Wells D-11 and D-12

\begin{tabular}{|c|c|c|c|c|c|c|c|c|}
\hline Y WIIL & 80 & $3 \%$ & $6 \%$ & $10 \%$ & 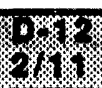 & oxy & $6 \%$ & (1) \\
\hline Chromium, mg/l & & & & & & & $<0.025$ & $<0.025$ \\
\hline Lead, dissolved,mg/l & & & $<0.005$ & 0.12 & & & $<0.005$ & $<0.005$ \\
\hline pH, units & 6.00 & 6.00 & 6.30 & 7.10 & 5.70 & 5.60 & 5.00 & 7.10 \\
\hline Phenolics as phenol, mg/1 & & & $<0.1$ & $<0.1$ & & & $<0.1$ & $<0.1$ \\
\hline Nitra: $\theta-\mathrm{N}, \mathrm{mg} / 1$ & & & 1.4 & 1.1 & & & 0.077 & $<0.05$ \\
\hline Total Organic Carbon, mo/1 & & & $<1$ & & & & $<1$ & \\
\hline Total Organic Halides, $m q / 1$ & & & 39 & & & & 110 & \\
\hline $\begin{array}{l}\text { Petroloum Hydrocarbons by } \\
\qquad / \mathrm{R}, \mathrm{mo} / 1\end{array}$ & & & $<1$ & & & & $<1$ & \\
\hline Ammonia-N, mo/1 & & $<0.5$ & $<0.5$ & $<0.5$ & & $<0.5$ & $<0.5$ & $<0.5$ \\
\hline Chloride, mo/1 & & & 29 & 26 & & & 18 & 19 \\
\hline Total Dissolved Solids, mq/1 & 150 & 170 & 170 & 130 & 150 & 150 & 130 & 150 \\
\hline Sulfate, $\mathrm{mg} / 1$ & 24 & 64 & 25 & 27 & 32 & 140 & 34 & $\overline{32}$ \\
\hline Conductivity, $4 \mathrm{mhos} / \mathrm{cm}^{2}$ & 130 & 260 & 290 & 260 & 150 & 200 & 190 & 250 \\
\hline
\end{tabular}

Table 36. 1992 Groundwater Analysis for Wells TW-2 and TW-3

\begin{tabular}{|c|c|c|c|c|c|c|c|c|}
\hline and & W & 3re. & 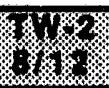 & WY\% & Sy & Wre & \% & 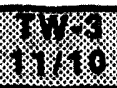 \\
\hline \multicolumn{9}{|l|}{ Chromium, mg/l } \\
\hline Lead, dissolved,mg/l & & & $<0.005$ & 0.0084 & & & $<0.005$ & 0.08 \\
\hline pH, units & 7.40 & 7.00 & 6.80 & 7.50 & 7.50 & 7.50 & 6.80 & 7.10 \\
\hline Phenolics as phenol, $\mathrm{mg} / 1$ & & & $<0.1$. & $<0.1$ & & & $<0.1$ & $<0.1$ \\
\hline Nitrate-N, mg/1 & & & 0.11 & $<0.05$ & & & 0.12 & 0.13 \\
\hline Total Organic Carbon, $\quad m g / 1$ & & & $<1$ & & & & $<1$ & \\
\hline Total Organic Halides, $\mathrm{mg} / 1$ & & & 40 & & & & 44 & \\
\hline $\begin{array}{l}\text { Petroloum Hydrocarbons by } \\
\text { IR, mg/1 }\end{array}$ & & & $<1$ & & & & $<1$ & \\
\hline Ammonia-N, mg/1 & & $<0.5$ & $<0.5$ & $<0.5$ & & $<0.5$ & $<0.5$ & $<0.5$ \\
\hline Chloride, $\mathrm{mg} / 1$ & & & 14 & 11 & & & $37^{\circ}$ & 29 \\
\hline Total Dissolved Solids, $\mathrm{mg} / 1$ & 220 & 220 & 240 & 220 & 20 & 220 & 290 & 260 \\
\hline Sulfate, $\mathrm{mg} / 1$ & 24 & 45 & 22 & 21 & $\overline{9}$ & 70 & 20 & 23 \\
\hline Conductivity, umhos $/ \mathrm{cm}^{2}$ & 270 & 370 & 380 & 270 & 290 & 380 & $355^{*}$ & 330 \\
\hline
\end{tabular}

Blank indicates no measurement.

"hesampled on $9 / 8 / 92$ 
Table 37. Groundwater Volatile Organics Analysis for May 1992 (in $\mu g /$ )

\begin{tabular}{|c|c|c|c|}
\hline 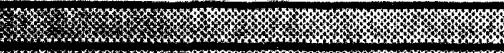 & $8 \times 18$ & $18 \times 1082$ & 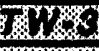 \\
\hline 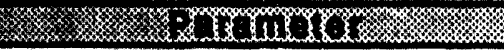 & ২/ / - - . & 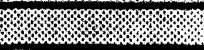 & \\
\hline Chloromethane & $<10$ & $<10$ & $<10$ \\
\hline Bromomethane & $\leq 10$ & $\leq 10$ & $\leq 10$ \\
\hline VinylChloride & $<10$ & $<10$ & $\leq 10$ \\
\hline Chloroethane & $<10$ & $<10$ & $<10$ \\
\hline Methylene Chloride & $<5$ & $<5$ & $<5$ \\
\hline Acrolein & $<20$ & $<20$ & $<20$ \\
\hline Acrylonitrile & $<20$ & $<20$ & $<20$ \\
\hline Trichlorofluoromethane & $\leq 5$ & $\leq 5$ & $<5$ \\
\hline 1,1-Dichloroethene & $<5$ & $<5$ & $<5$ \\
\hline 1,1-Dichloroethane & $\leq 5$ & $3 J$ & $<5$ \\
\hline Trans-1,2-Dichloroethene & $<5$ & $<5$ & $<5$ \\
\hline Chloroform & $<5$ & $<5$ & $<5$ \\
\hline 1,2-Dichloroethane & $<5$ & $<5$ & $<5$ \\
\hline 1,1,1-Trichloroethane & $<5$ & $<5$ & $<5$ \\
\hline Carbon Tetrachloride & $<5$ & $<5$ & $<5$ \\
\hline Bromodichloromethane & $<5$ & $<5$ & $<5$ \\
\hline 1,2-Dichloropropane & $<5$ & $<5$ & $<5$ \\
\hline cis-1,3-Dichloropropane & $<5$ & $\leq 5$ & $<5$ \\
\hline Trichloroethene & $<5$ & $<5$ & $<5$ \\
\hline Dibromochloromethane & $<5$ & $<5$ & $<5$ \\
\hline 1,1,2-Trichloroethane & $<5$ & $<5$ & $<5$ \\
\hline Benzeno & $<5$ & $<5$ & $<5$ \\
\hline Irans-1,3-Dichloropropene & $<5$ & $<5$ & $<5$ \\
\hline 2-Chloroethylvinylether & $<10$ & $<10$ & $<10$ \\
\hline Bromoform & $<5$ & $<5$ & $<5$ \\
\hline Tetrachloroethene & 5 & 5 & $4 J$ \\
\hline 1,1,2,2-Tetrachloroethane & $<5$ & $<5$ & $<5$ \\
\hline Toluene & $<5$ & $<5$ & $<5$ \\
\hline Chlorobenzene & $<5$ & $<5$ & $<5$ \\
\hline Ethylbenzene & $<5$ & $<5$ & $<5$ \\
\hline 1,3-Dichlorobenzene & $<5$ & $<5$ & $<5$ \\
\hline $1,2 \& 1,4$-Dichlorobenzenes & & & \\
\hline
\end{tabular}

$J$ indicates a value below the reliable limit of detection.

Field and trip blanks were all below method detection limit. 

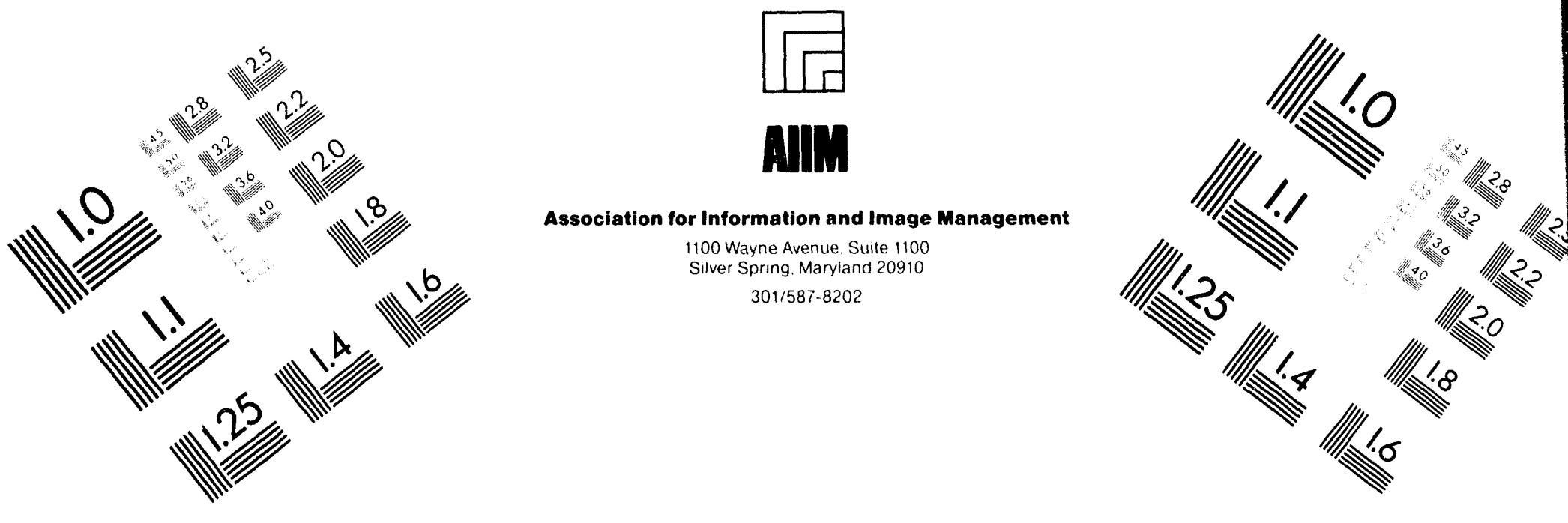

\section{Centimeter}

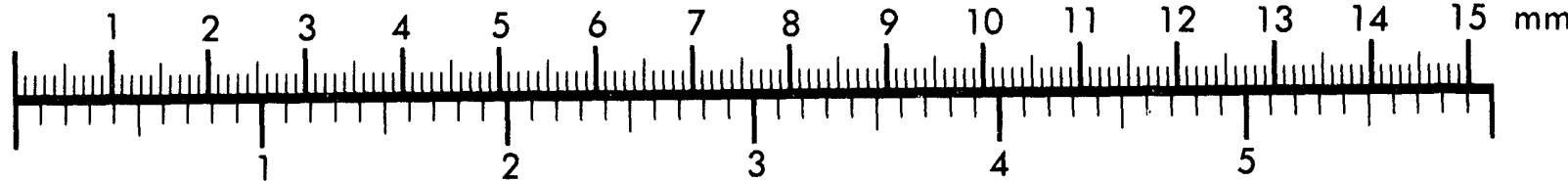

Inches
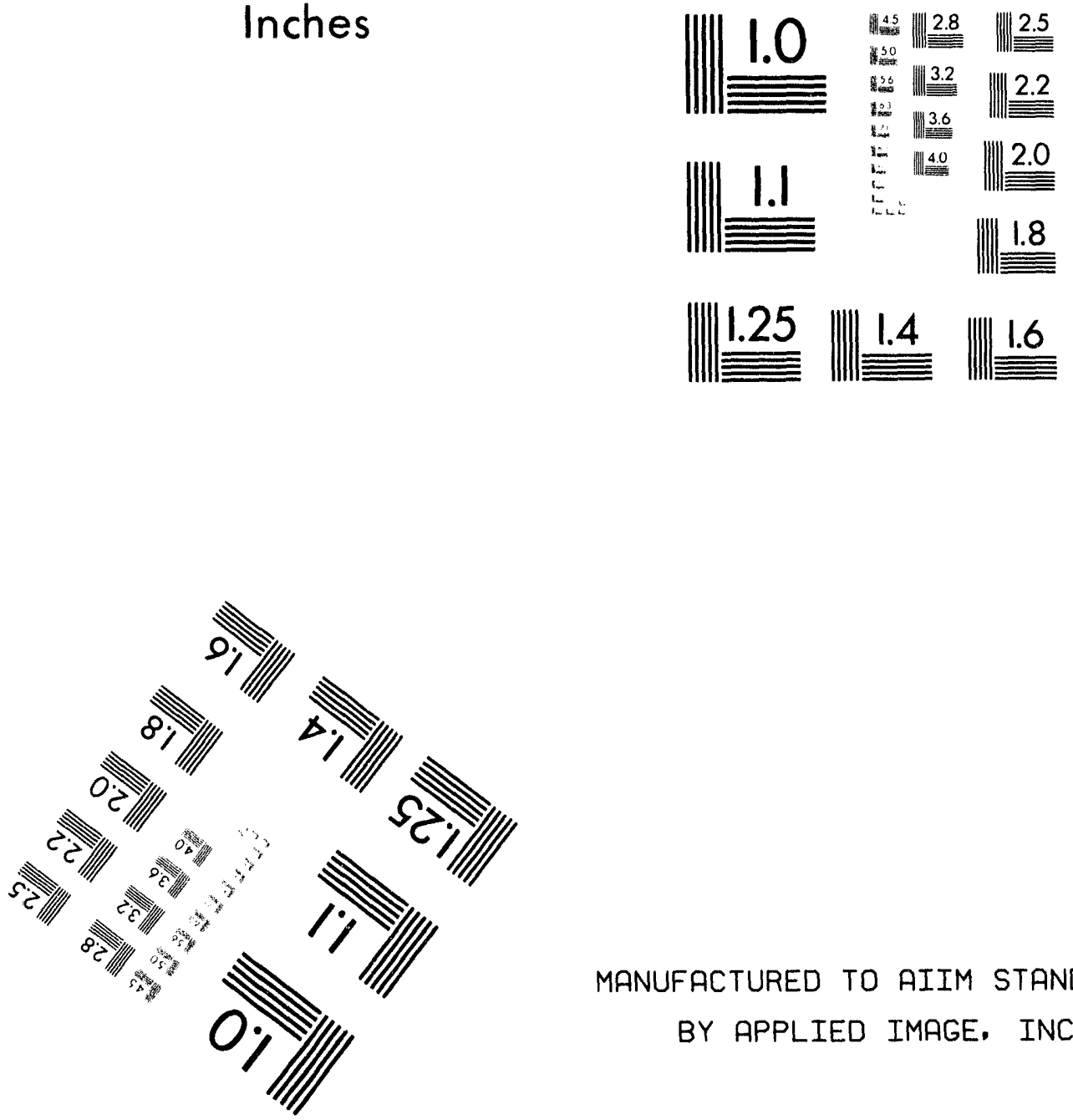

MANUFACTURED TO AIIM STANDARDS

BY APPLIED IMAGE, INC.

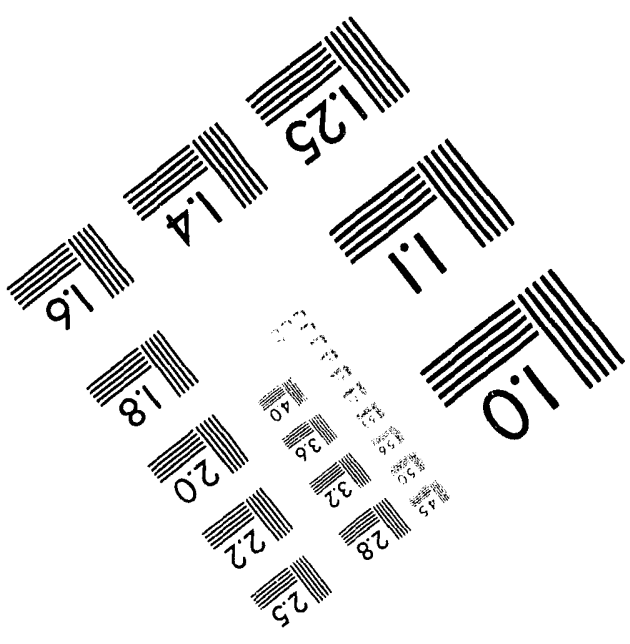



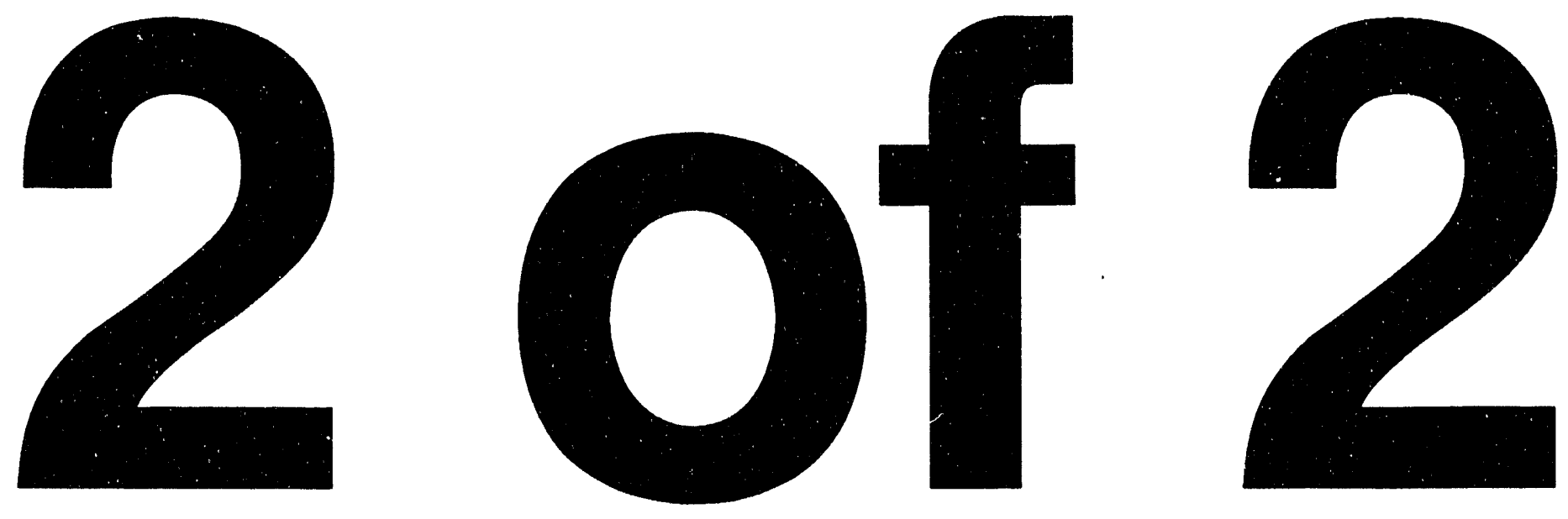
Table 38. Groundwater Volatile Organics Analysis and Detention Basin Volatile Organics Analysis for August 1992 (in $\mu \mathrm{g} / \mathrm{l}$ )

\begin{tabular}{|c|c|c|c|c|c|}
\hline & $8 \% 1 \%$ & $10 \%$ & $18 \%$ & $101 \% 1 \%$ & $101 \%$ \% \\
\hline 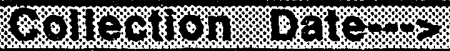 & $6968 \% 2$ & $81 \% 39 \%$ & $6913 \% 2$ & $8 \% 1 \% 2$ & $8 \% \% \%$ \\
\hline Chloromethane & $<10$ & $<10$ & $<10$ & $<10$ & $<10$ \\
\hline Bromomethane & $<10$ & $<10$ & $<10$ & $<10$ & $<10$ \\
\hline Vinyl Chloride & $<10$ & $<10$ & $<10$ & $<10$ & $<10$ \\
\hline Chloroethane & $<10$ & $<10$ & $<10$ & $<10$ & $<10$ \\
\hline Methylene Chloride & $<5$ & $<5$ & $<5$ & $<5$ & $<5$ \\
\hline Acrolein & $<20$ & $<20$ & $<20$ & $<20$ & $<20$ \\
\hline Acrylonitrile & $<20$ & $<20$ & $<20$ & $<20$ & $<20$ \\
\hline Trichlorofluoromethane & $<5$ & $<5$ & $<5$ & $<5$ & $<5$ \\
\hline 1,1-Dichloroethene & $<5$ & $<5$ & $<5$ & $<5$ & $<5$ \\
\hline 1,1-Dichloroethane & $<5$ & $4 J$ & $<5$ & $<5$ & $<5$ \\
\hline Trans-1,2-Dichloroethene & $<5$ & $<5$ & $<5$ & $<5$ & $<5$ \\
\hline Chloroform & $<5$ & $<5$ & $<5$ & $<5$ & $<5$ \\
\hline 1,2-Dichloroethane & $<5$ & $<5$ & $<5$ & $<5$ & $<5$ \\
\hline 1,1,1-Trichloroethane & $<5$ & $<5$ & $<5$ & $<5$ & $<5$ \\
\hline Carbon Tetrachloride & $<5$ & $<5$ & $<5$ & $<5$ & $<5$ \\
\hline Bromodichloromethane & $<5$ & $<5$ & $<5$ & $<5$ & $<5$ \\
\hline 1,2-Dichloropropane & $<5$ & $<5$ & $<5$ & $<5$ & $<5$ \\
\hline cis-1,3-Dichloropropene & $<5$ & $<5$ & $<5$ & $<5$ & $<5$ \\
\hline Trichloroethene & $<5$ & $<5$ & $<5$ & $<5$ & $<5$ \\
\hline Dibromochloromethane & $<5$ & $<5$ & $<5$ & $<5$ & $<5$ \\
\hline 1,1,2-Trichloroethane & $<5$ & $<5$ & $<5$ & $<5$ & $<5$ \\
\hline Benzene & $<5$ & $<5$ & $<5$ & $<5$ & $<5$ \\
\hline trans-1,3-Dichloropropene & $<5$ & $<5$ & $<5$ & $<5$ & $<5$ \\
\hline 2-Chloroethylvinylether & $<10$ & $<10$ & $<10$ & $<10$ & $<10$ \\
\hline Bromoform & $<5$ & $<5$ & $<5$ & $<5$ & $<5$ \\
\hline Tetrachloroethene & 3J & 14 & 36 & $<5$ & $<5$ \\
\hline 1,1,2,2-Tetrachloroethane & $<5$ & $<5$ & $<5$ & $<5$ & $<5$ \\
\hline Toluene & $<5$ & $<5$ & $<5$ & $<5$ & $<5$ \\
\hline Chlorobenzene & $<5$ & $<5$ & $<5$ & $<5$ & $<5$ \\
\hline Ethylbenzene & $<5$ & $<5$ & $<5$ & $<5$ & $<5$ \\
\hline
\end{tabular}

$J$ indicates a value below the reliable limit of detection.

Field and trip blanks were all below method detection limit. 
Table 39. Groundwater Base Neutrals Analysis for August 1992 (in $\mu g / l$ )

\begin{tabular}{|c|c|c|c|c|c|c|c|}
\hline & D. $1 \%$ & $\mathrm{BBT2}$ & $\mathrm{MWrTM}$ & MW 15 & MW 65 & TW2. & WW \\
\hline N-nitrosodimethylamine & $<10$ & $<10$ & $<10$ & $<10$ & $<10$ & $<10$ & $<10$ \\
\hline bis(2-Chloroethyl)ether & $<10$ & $<10$ & $<10$ & $<10$ & $<10$ & $<10$ & $<10$ \\
\hline 1,3-Dichlorobenzene & $<10$ & $<10$ & $<10$ & $<10$ & $<10$ & $<10$ & $<10$ \\
\hline 1,4-Dichlorobenzene & $<10$ & $<10$ & $<10$ & $<10$ & $<10$ & $<10$ & $<10$ \\
\hline 1,2-Dichlorobenzene & $<10$ & $<10$ & $<10$ & $<10$ & $<10$ & $<10$ & $<10$ \\
\hline bis(2-Chloroisopropyl)ether & $<10$ & $<10$ & $<10$ & $<10$ & $<10$ & $<10$ & $<10$ \\
\hline N-Nitroso-di-n-propylamine & $<10$ & $<10$ & $<10$ & $<10$ & $<10$ & $<10$ & $<10$ \\
\hline Hexachloroethane & $<10$ & $<10$ & $<10$ & $<10$ & $<10$ & $<10$ & $<10$ \\
\hline Nitrobenzene & $<10$ & $<10$ & $<10$ & $<10$ & $<10$ & $<10$ & $<10$ \\
\hline Isophorone & $<10$ & $<10$ & $<10$ & $<10$ & $<10$ & $<10$ & $<10$ \\
\hline $\begin{array}{l}\text { bis(2- } \\
\text { Chloroethoxy)Methane }\end{array}$ & $<10$ & $<10$ & $<10$ & $<10$ & $<10$ & $<10$ & $<10$ \\
\hline 1,2,4-Trichlorobenzene & $<10$ & $<10$ & $<10$ & $<10$ & $<10$ & $<10$ & $<10$ \\
\hline Naphthalene & $<10$ & $<10$ & $<10$ & $<10$ & $<10$ & $<10$ & $<10$ \\
\hline Hexachlorobutadiene & $<10$ & $<10$ & $<10$ & $<10$ & $<10$ & $<10$ & $<10$ \\
\hline Hexachlorocyclopentadiene & $<10$ & $<10$ & $<10$ & $<10$ & $<10$ & $<10$ & $<10$ \\
\hline 2-Chloronaphthalene & $<10$ & $<10$ & $<10$ & $<10$ & $<10$ & $<10$ & $<10$ \\
\hline Dimethylphthalate & $<10$ & $<10$ & $<10$ & $<10$ & $<10$ & $<10$ & $<10$ \\
\hline Acenaphthylene & $<10$ & $<10$ & $<10$ & $<10$ & $<10$ & $<10$ & $<10$ \\
\hline Acenaphthene & $<10$ & $<10$ & $<10$ & $<10$ & $<10$ & $<10$ & $<10$ \\
\hline 2,4-Dinitrotoluene & $<10$ & $<10$ & $<10$ & $<10$ & $<10$ & $<10$ & $<10$ \\
\hline 2,6-Dinitrotoluene & $<10$ & $<10$ & $<10$ & $<10$ & $<10$ & $<10$ & $<10$ \\
\hline Diethylphthalate & $<10$ & $<10$ & $<10$ & $<10$ & $<10$ & $<10$ & $<10$ \\
\hline 4-Chlorophenyl-phenylether & $<10$ & $<10$ & $<10$ & $<10$ & $<10$ & $<10$ & $<10$ \\
\hline Fluorene & $<10$ & $<10$ & $<10$ & $\leq 10$ & $<10$ & $=10$ & $<10$ \\
\hline N-Nitrosodiphenylamine & $<10$ & $<10$ & $<10$ & $<10$ & $<10$ & $<10$ & $<10$ \\
\hline 1,2-diphenylhydrazine & $<10$ & $<10$ & $<10$ & $<10$ & $<10$ & $<10$ & $<10$ \\
\hline 4-Bromophenyl-phenylether & $<10$ & $<10$ & $<10$ & $<10$ & $<10$ & $<10$ & $<10$ \\
\hline Hexachlorobenzene & $<10$ & $<10$ & $<10$ & $<10$ & $\leq 10$ & $\leq 10$ & $<10$ \\
\hline Phenathrene & $<10$ & $<10$ & $<10$ & $<10$ & $<10$ & $<10$ & $<10$ \\
\hline Anthracene & $<10$ & $<10$ & $<10$ & $<10$ & $<10$ & $<10$ & $<10$ \\
\hline Di-n-Butylphthalate & $<10$ & $<10$ & $<10$ & $<10$ & $<10$ & $<10$ & $<10$ \\
\hline Fluoranthene & $<10$ & $<10$ & $<10$ & $<10$ & $<10$ & $<10$ & $<10$ \\
\hline Benzidine & $<50$ & $<50$ & $<50$ & $<50$ & $<50$ & $<50$ & $<50$ \\
\hline Pyrene & $<10$ & $<10$ & $<10$ & $<10$ & $<10$ & $<10$ & $<10$ \\
\hline Butylbenzylphthalate & $<10$ & $<10$ & $<10$ & $<10$ & $<10$ & $<10$ & $<10$ \\
\hline 3,3'-Dichlorobenzidine & $<20$ & $<20$ & $<20$ & $<20$ & $<20$ & $<20$ & $<20$ \\
\hline Benzo (a) Anthracene & $<10$ & $<10$ & $<10$ & $<10$ & $<10$ & $<10$ & $<10$ \\
\hline Bis(2-ethylhexyl)Phthalate & $<10$ & $<10$ & $<10$ & $<10$ & $<10$ & $7 \mathrm{~J}$ & $<10$ \\
\hline Chrysene & $<10$ & $<10$ & $<10$ & $<10$ & $<10$ & $<10$ & $<10$ \\
\hline Di-n-octylphthalate & $<10$ & $<10$ & $<10$ & $<10$ & $<10$ & $<10$ & $<10$ \\
\hline Benzo (b) fluoranthene & $<10$ & $<10$ & $<10$ & $<10$ & $<10$ & $<10$ & $<10$ \\
\hline Benzo (k) Fluoranthene & $\leq 10$ & $<10$ & $<10$ & $<10$ & $<10$ & $<10$ & $\leq 10$ \\
\hline Benzo (a) Pyrene & $\leq \overline{10}$ & $<10$ & $<10$ & $<10$ & $<10$ & $<10$ & $<10$ \\
\hline Indeno $(1,2,3-\mathrm{cd})$ Pyrene & $<10$ & $<10$ & $<10$ & $<10$ & $<10$ & $<10$ & $<10$ \\
\hline Dibenzo $(a, h)$ Anthracene & $<10$ & $<10$ & $<10$ & $<10$ & $<10$ & $<10$ & $<10$ \\
\hline Benzo $(g, h, i)$ Perylene & $<10$ & $<10$ & $<10$ & $<10$ & $<10$ & $<10$ & $<10$ \\
\hline
\end{tabular}

$J$ indicates a value below the reliable limit of detection.

Field and trip blanks were all below method detection limit. 
Table 40. PPPL REML QA/QC From EPA/Las Vegas

\begin{tabular}{|c|c|c|c|}
\hline Radioisotope & $\begin{array}{c}\mathrm{pCI} / \mathrm{L} \\
\text { Known Value }\end{array}$ & $\begin{array}{c}\mathrm{PCl} / \mathrm{L} \\
\text { Control Limits }\end{array}$ & $\begin{array}{c}\text { PCI/L } \\
\text { PPPL Values }\end{array}$ \\
\hline \multicolumn{4}{|l|}{ February 92 - EPA Las Vegas } \\
\hline $\begin{array}{l}\text { H-3 } \\
\text { Co-60 } \\
\text { Zn-65 } \\
\text { Ru-106 } \\
\text { Cs-134 } \\
\text { Cs-137 } \\
\text { Ba-133 }\end{array}$ & $\begin{array}{c}7,904 \\
40 \\
148 \\
203 \\
31 \\
49 \\
76 \\
\end{array}$ & $\begin{array}{c}7,942.8 \\
40.1 \\
148.8 \\
194.6 \\
29.4 \\
50.7 \\
75.1 \\
\end{array}$ & $\begin{array}{c}7,608.3 \\
35.7 \\
140.3 \\
200.7 \\
30.0 \\
50.0 \\
77.3\end{array}$ \\
\hline \multicolumn{4}{|l|}{ June 92 - EPA Las Vegas } \\
\hline $\begin{array}{l}H-3 \\
\text { Co-60 } \\
\text { Zn-65 } \\
\text { Ru-106 } \\
\text { Cs-134 } \\
\text { Cs-137 } \\
\text { Ba-133 }\end{array}$ & $\begin{array}{l}2,125 \\
20 \\
99 \\
141 \\
15 \\
15 \\
98\end{array}$ & $\begin{array}{c}2,101.6 \\
20.6 \\
104.7 \\
138.5 \\
14.8 \\
16.1 \\
96.2 \\
\end{array}$ & $\begin{array}{c}2,288.7 \\
19.3 \\
104.7 \\
145.3 \\
15.7 \\
15.0 \\
98.7\end{array}$ \\
\hline \multicolumn{4}{|c|}{ October 92 - EPA Las Vegas } \\
\hline $\begin{array}{l}H-3 \\
\text { Co-60 } \\
\text { Zn-65 } \\
\text { Ru-106 } \\
\text { Cs-134 } \\
\text { Cs-137 } \\
\text { Ba-133 }\end{array}$ & $\begin{array}{c}5,962 \\
10 \\
148 \\
175 \\
8 \\
8 \\
74\end{array}$ & $\begin{array}{c}5,997.4 \\
11 \\
157.1 \\
160.7 \\
8.1 \\
8.7 \\
73 \\
\end{array}$ & $\begin{array}{c}5.833 .3 \\
9.0 \\
157.0 \\
147.3 \\
8.7 \\
7.3 \\
76.3 \\
\end{array}$ \\
\hline
\end{tabular}


Table 41. QA Sample Data

\begin{tabular}{|c|c|c|c|c|}
\hline 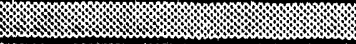 & \$SYK & $5 \% 15$ & 12218 & $112 \% 8$ \\
\hline Saramorers, UnIS & & & & \\
\hline Chromium total, $\mathrm{mg} / 1$ & $<0.01$ & 0.02 & $<0.01$ & $<0.01$ \\
\hline $\mathrm{pH}$, units & 7.46 & 7.23 & 7.40 & 7.40 \\
\hline $\begin{array}{c}\text { Phenolics Phenol, } \\
\mathrm{mg} / 1\end{array}$ & $<0.1$ & $<0.1$ & $<0.05$ & $<0.05$ \\
\hline $\begin{array}{l}\text { Chemical Oxygen } \\
\text { Demand, } \mathrm{mg} / \mathrm{t}\end{array}$ & $<20$ & 34 & $<20$ & $<20$ \\
\hline $\begin{array}{c}\text { Biochemical Oxygen } \\
\text { Demand, 5-day total, } \\
\mathrm{mg} / 1\end{array}$ & 4.5 & 14.0 & $<4.0$ & $<4.0$ \\
\hline $\begin{array}{c}\text { Petroleum } \\
\text { Hydrocarbons by IR, } \\
\mathrm{mg} / 1\end{array}$ & $<1$ & $<1$ & $<1$ & $<1$ \\
\hline Ammonia- $N$, mg/1 & $<0.5$ & $<0.5$ & $<0.5$ & $<0.5$ \\
\hline $\begin{array}{l}\text { Total Suspended } \\
\text { Solids, mg/1 }\end{array}$ & 9.0 & 13.0 & $<5.0$ & $<5.0$ \\
\hline $\begin{array}{l}\text { Total Dissolved } \\
\text { Solids, } \mathrm{mg} / 1\end{array}$ & 160 & 78 & 100 & 110 \\
\hline Temperature ${ }^{\circ} \mathrm{C}$ & 14 & 17 & 4 & 4 \\
\hline Flow, GPM & 5,671 & 10,156 & 7,322 & \\
\hline
\end{tabular}

Blank space indicates no measurement. 


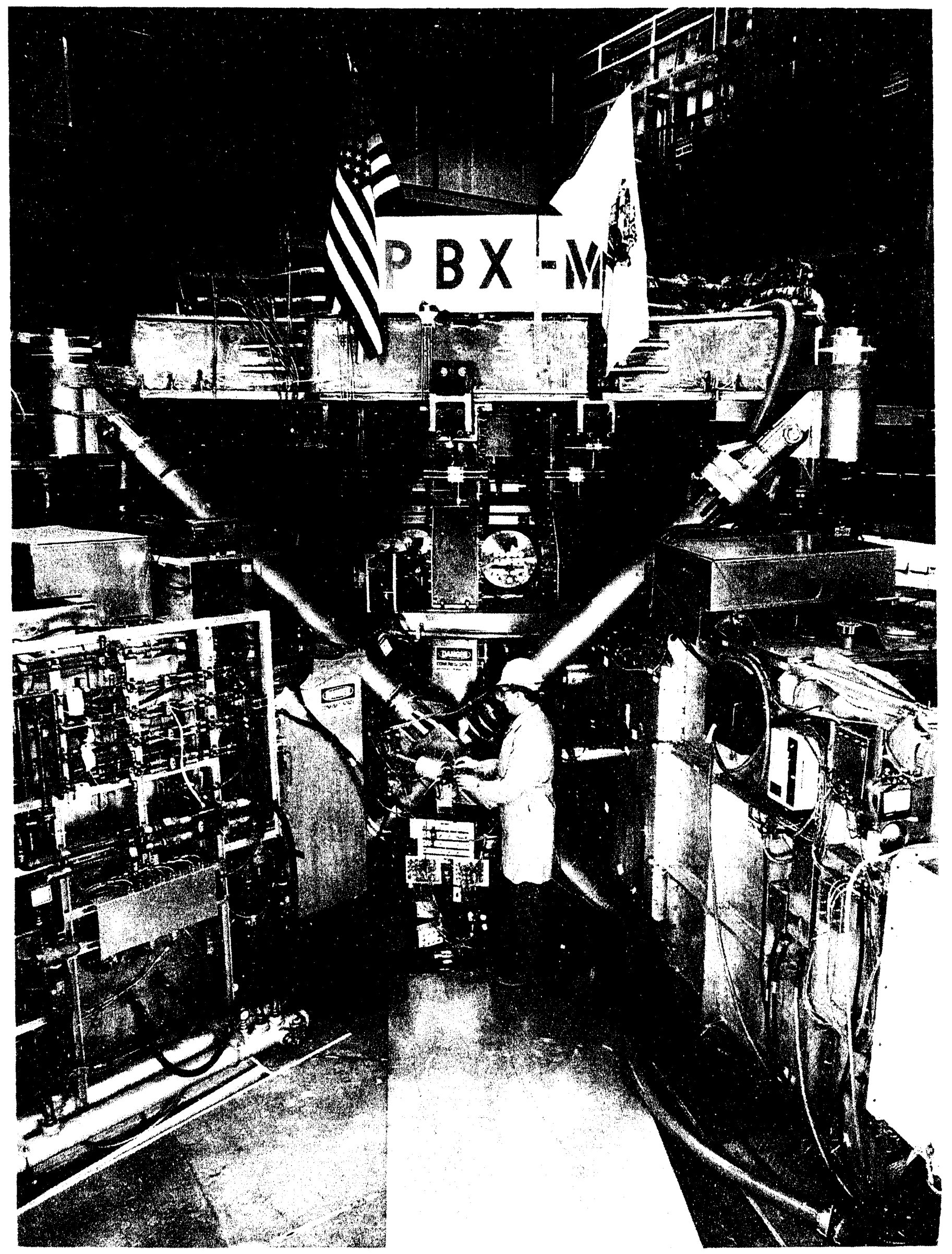

Figure 1.

The Princeton Beta Experiment-Modification

(PBX-M) 


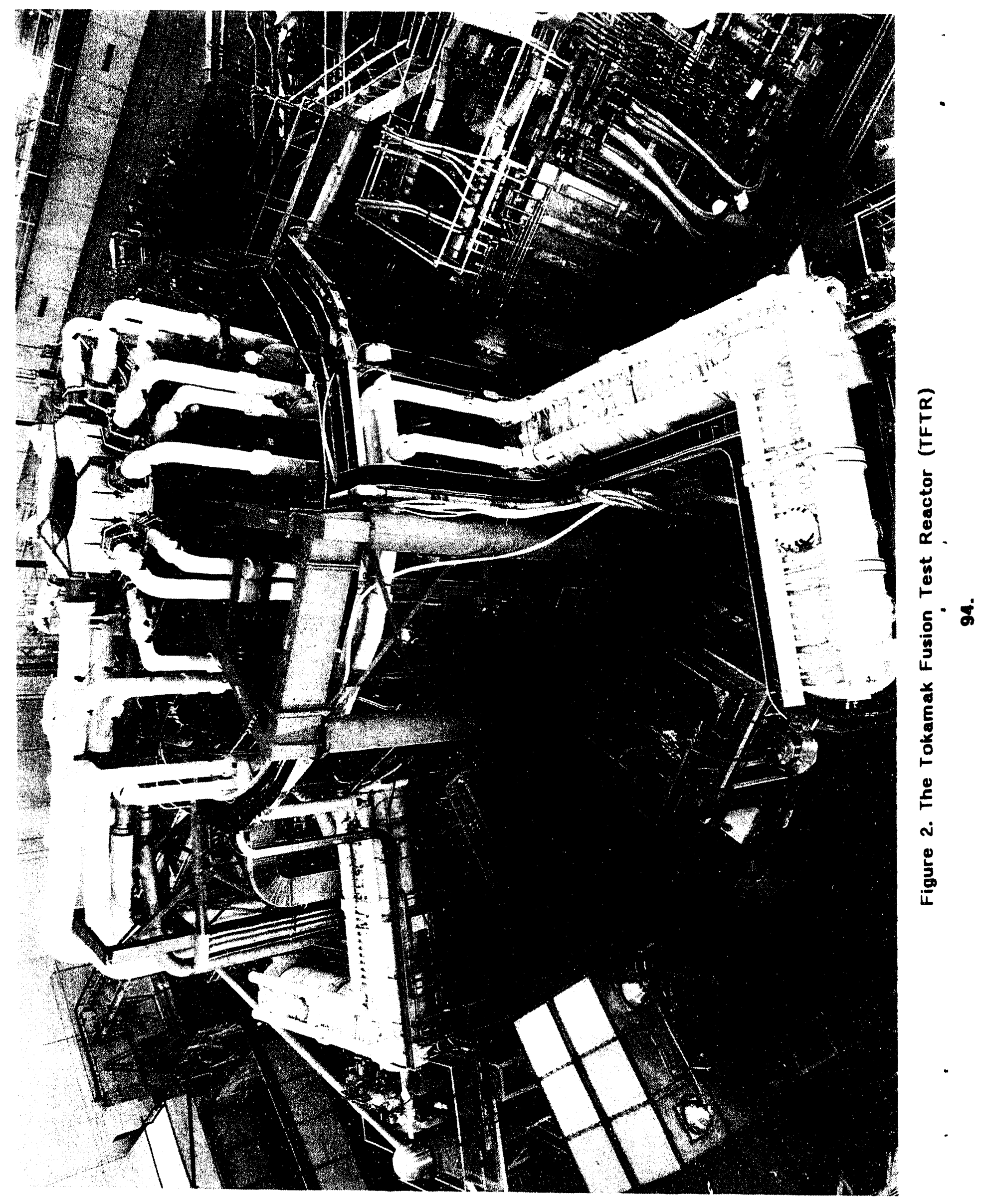




\section{Wind Rose}

Joint Frequency Data for TFTR

$$
84 / 1 \text { to } 92 / 12
$$

Elevation $10 \mathrm{~m}$, Extrapolated

For All Stability Class (100.0\%)

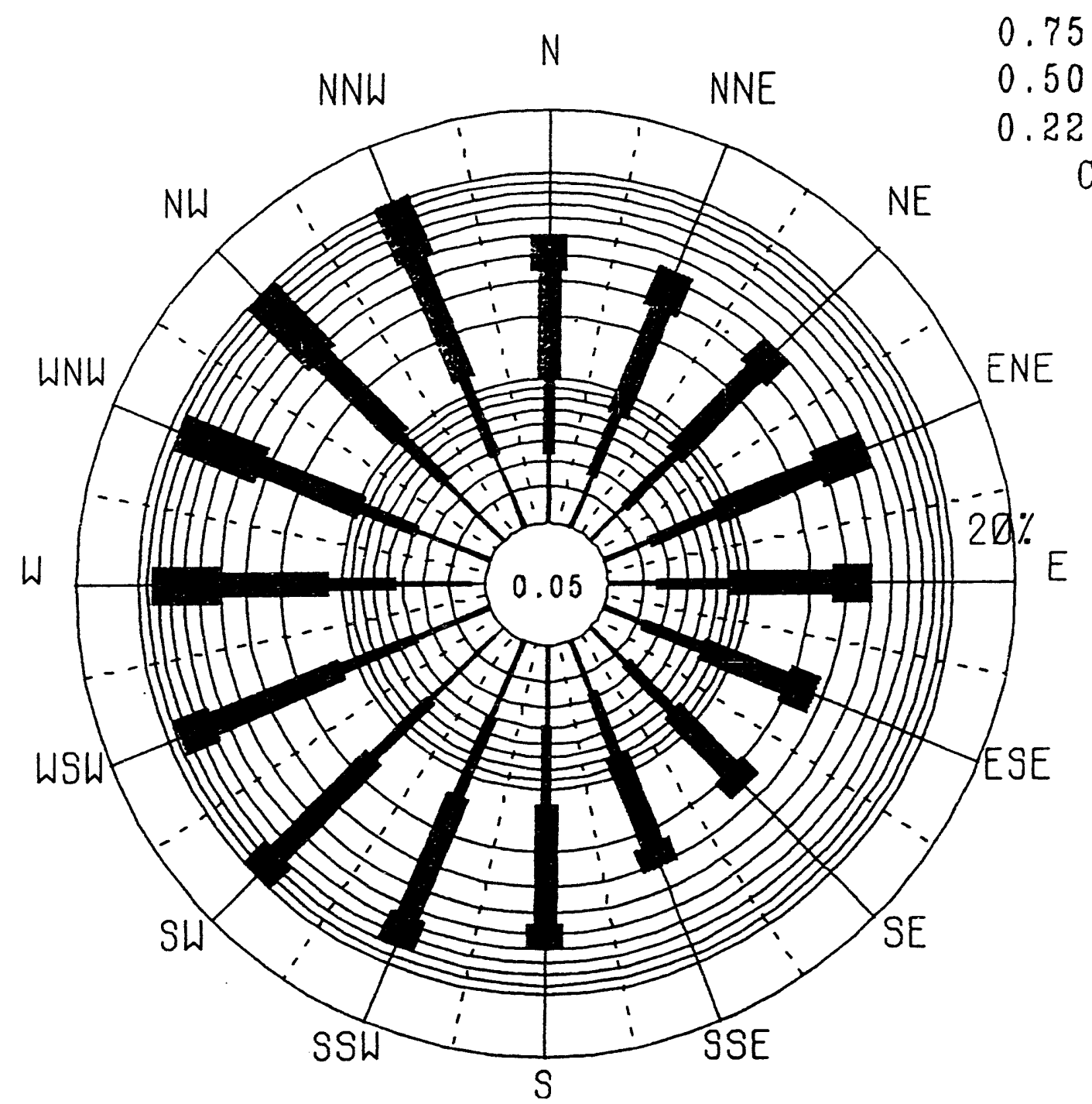

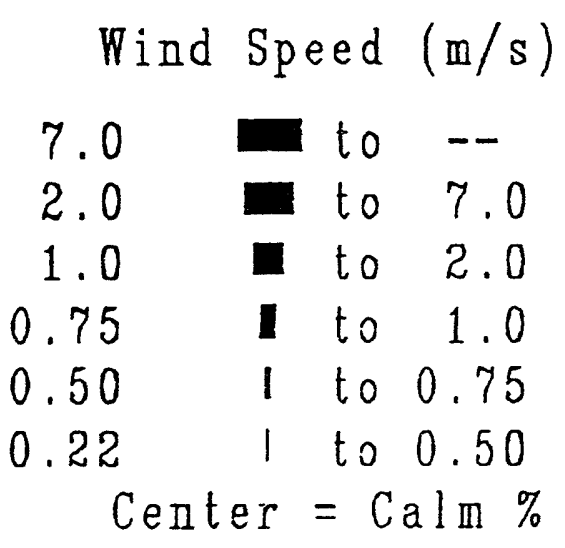

Figure 3. Wind Rose Joint Frequency Data for TFTR at 10m, 1984 to 1992

95. 


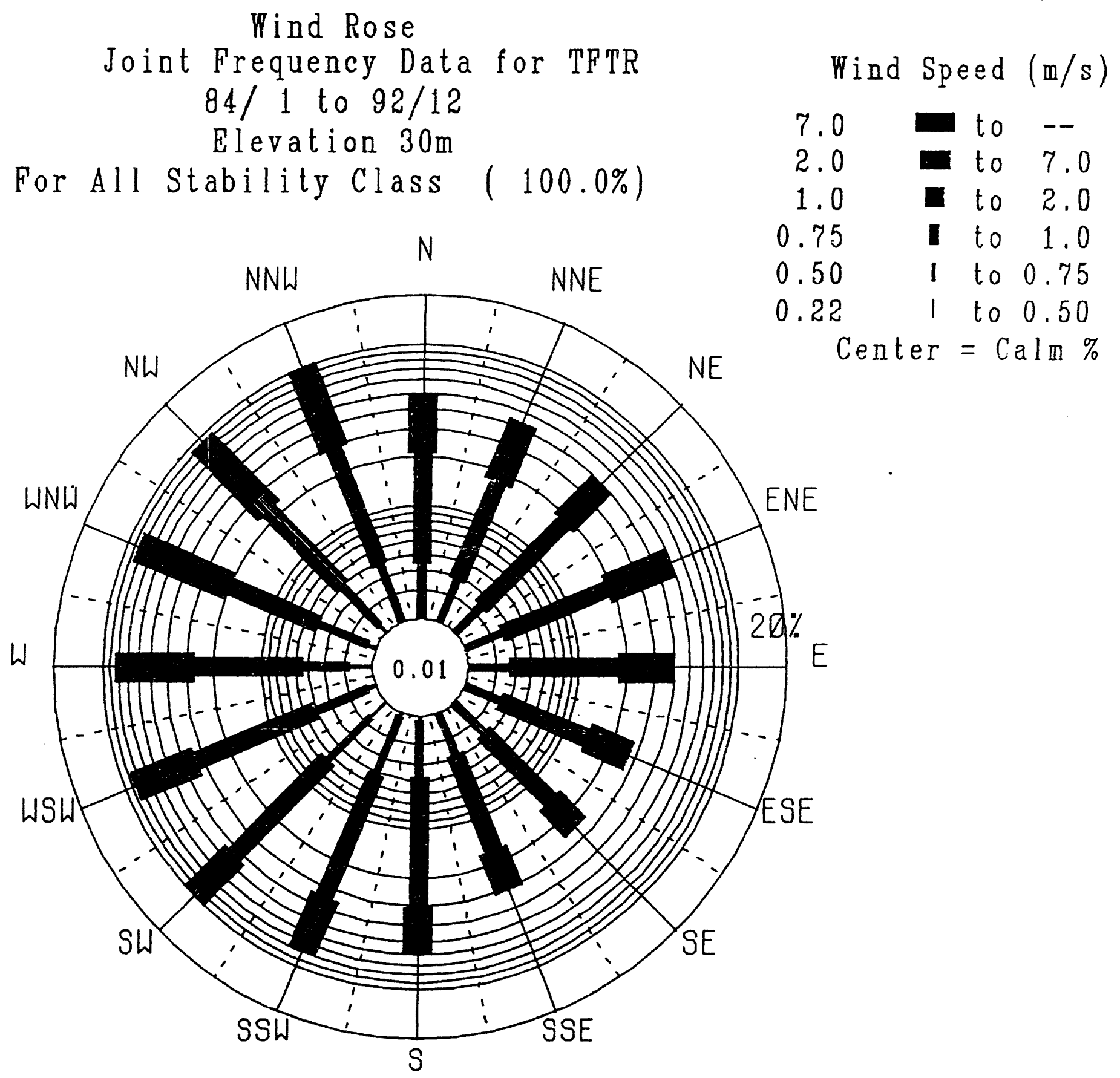

Figure 4. Wind Rose Joint Frequency Data for TFTR at $30 \mathrm{~m}, 1984$ to 1992

96. 


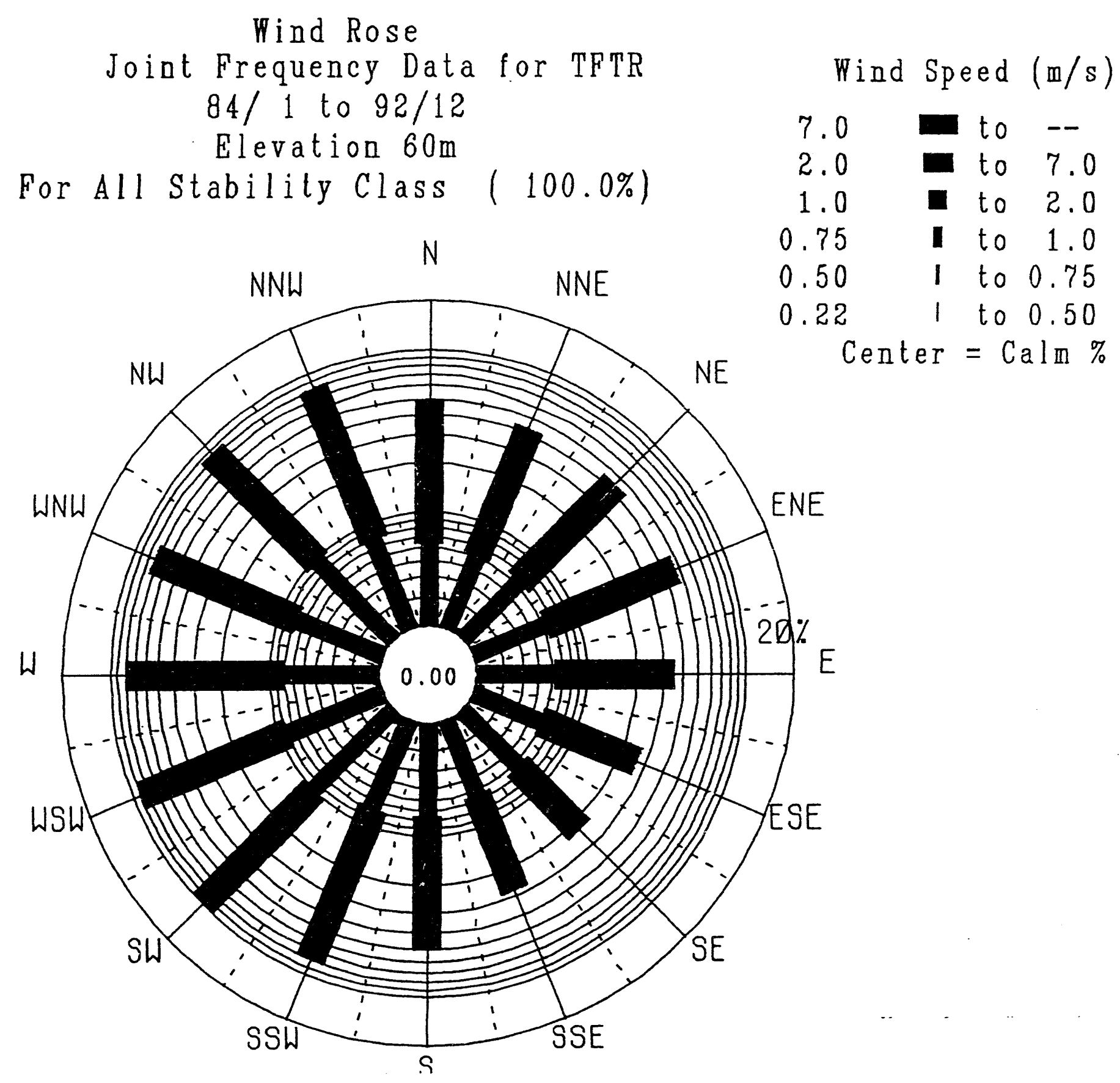

Figure 5. Wind Rose Joint Frequency Data for TFTR at $60 \mathrm{~m}, 1984$ to 1992 
Temperature (Deg. F)
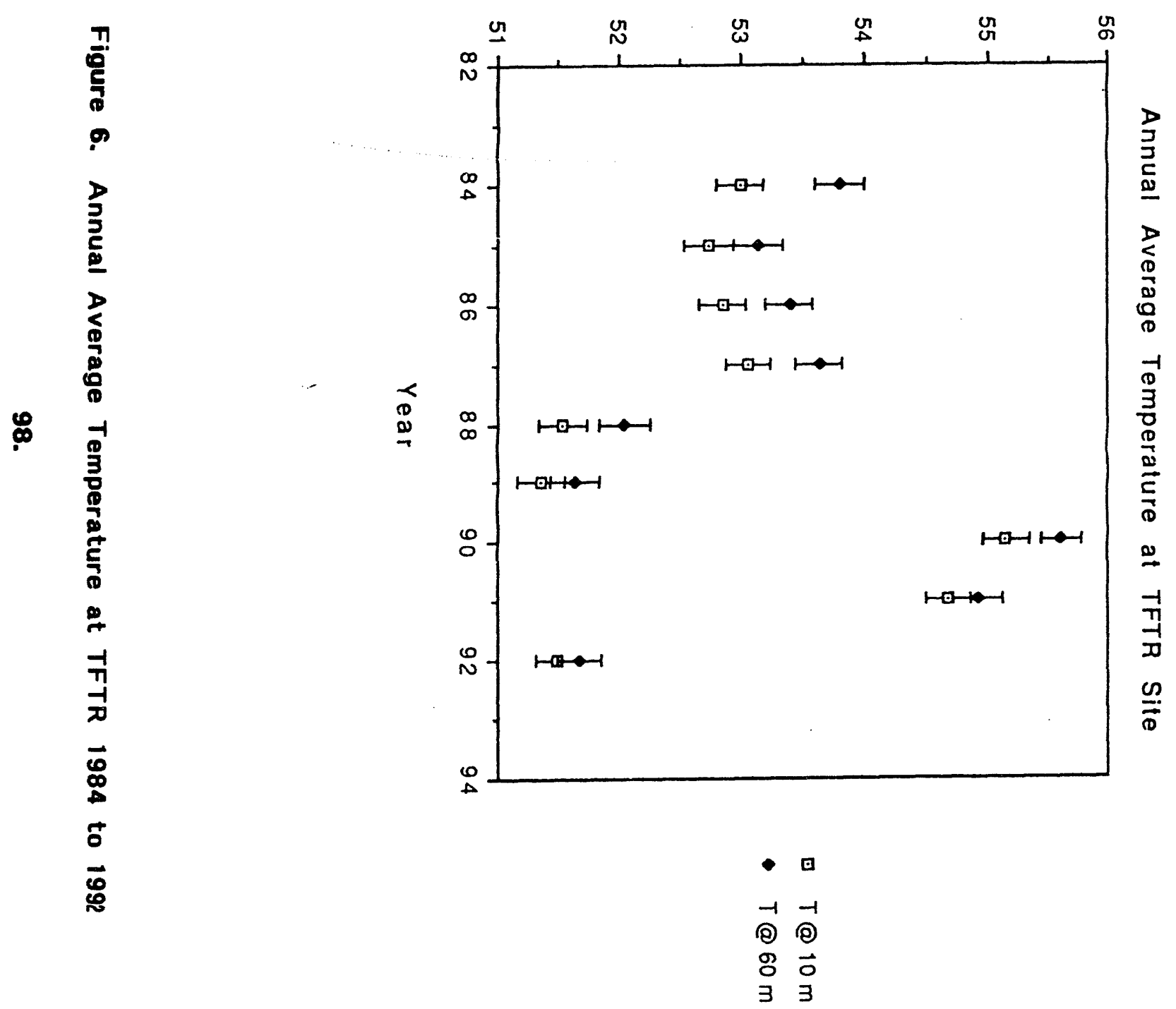


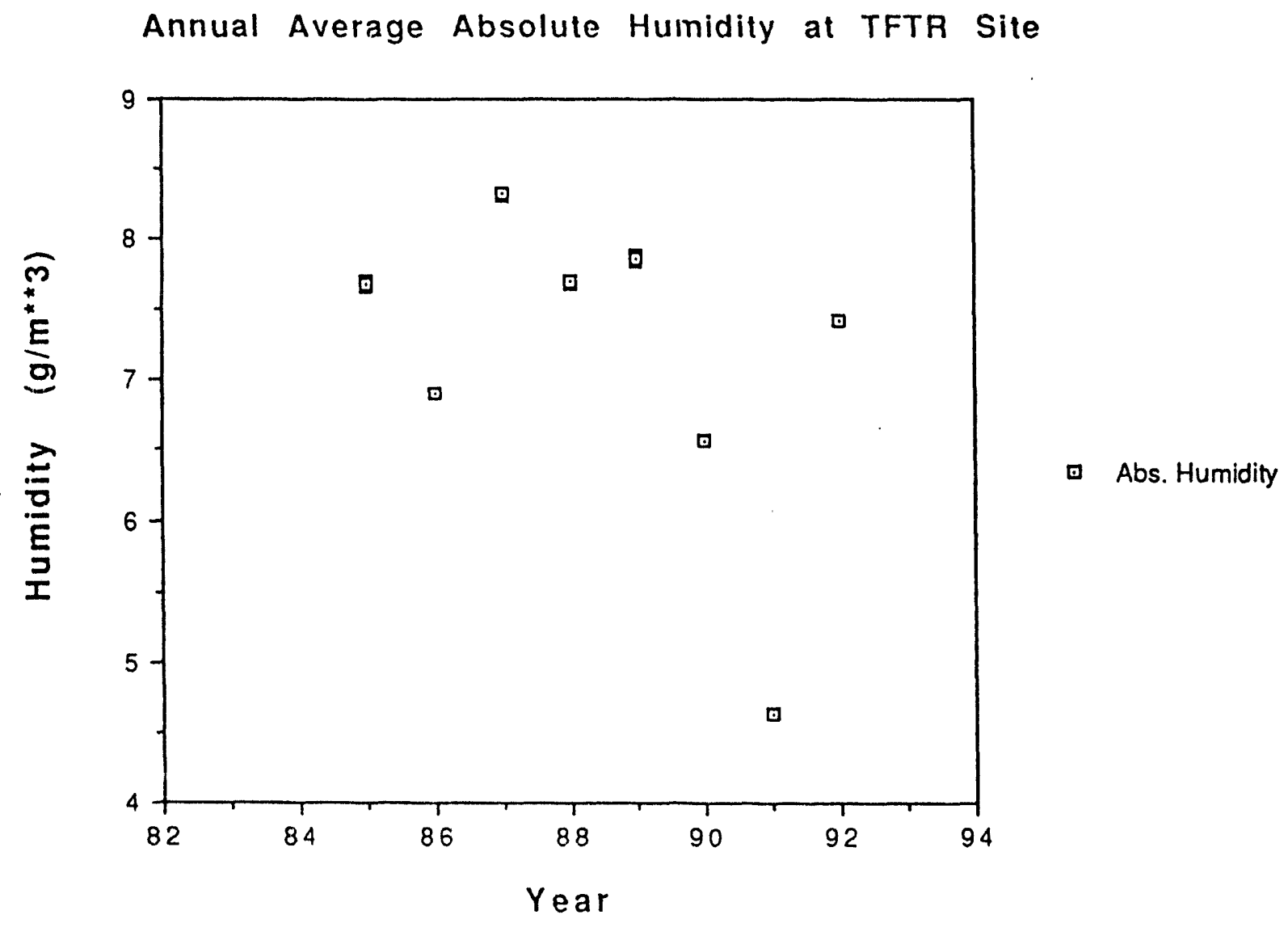

Figure 7. Annual Average Absolute Humidity at TFTR Site, 1984 to 1992 99. 


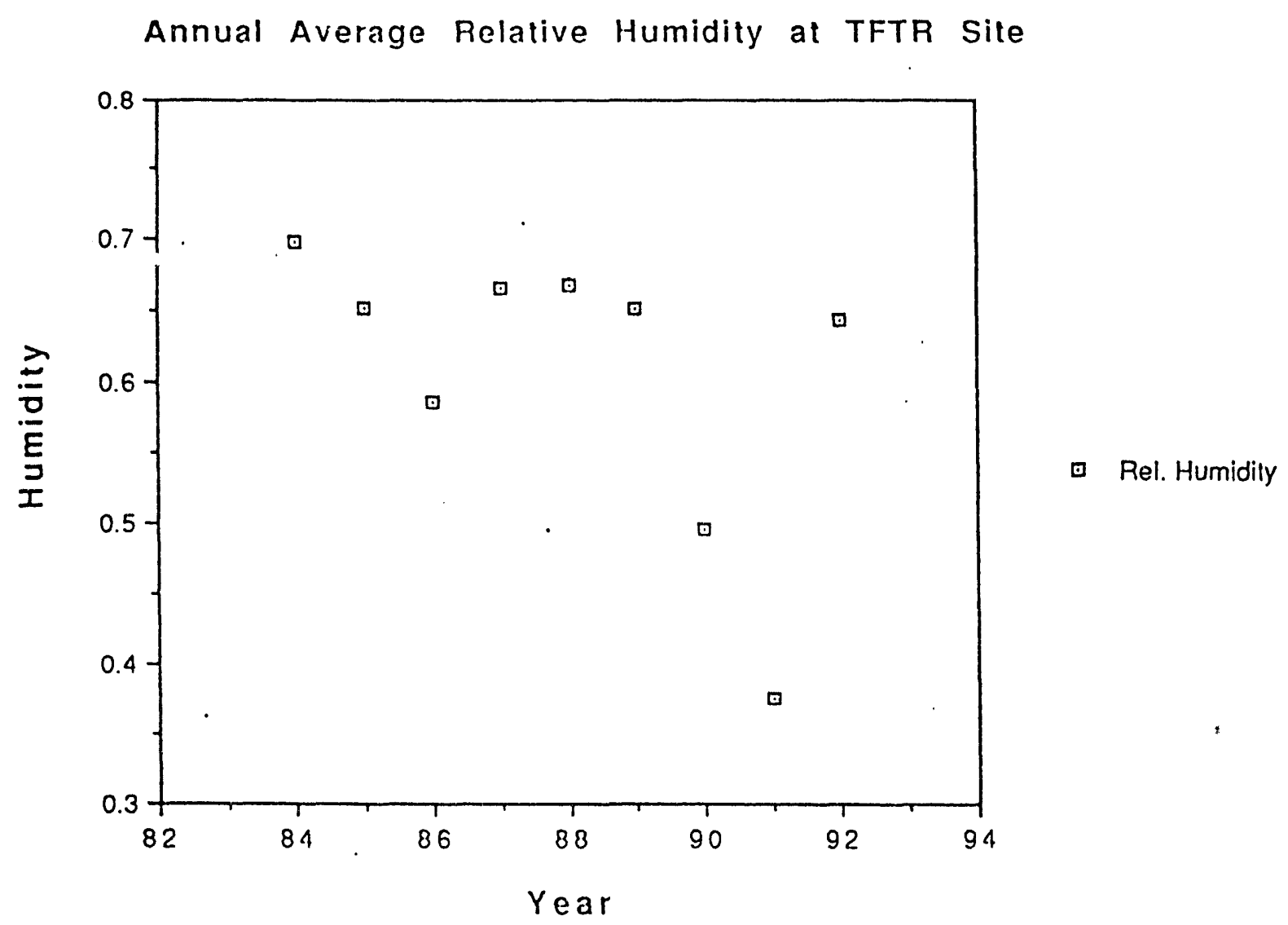

Figure 8. Annual Average Relative Humidity at TFTR Site, 1984 to 1992

100. 


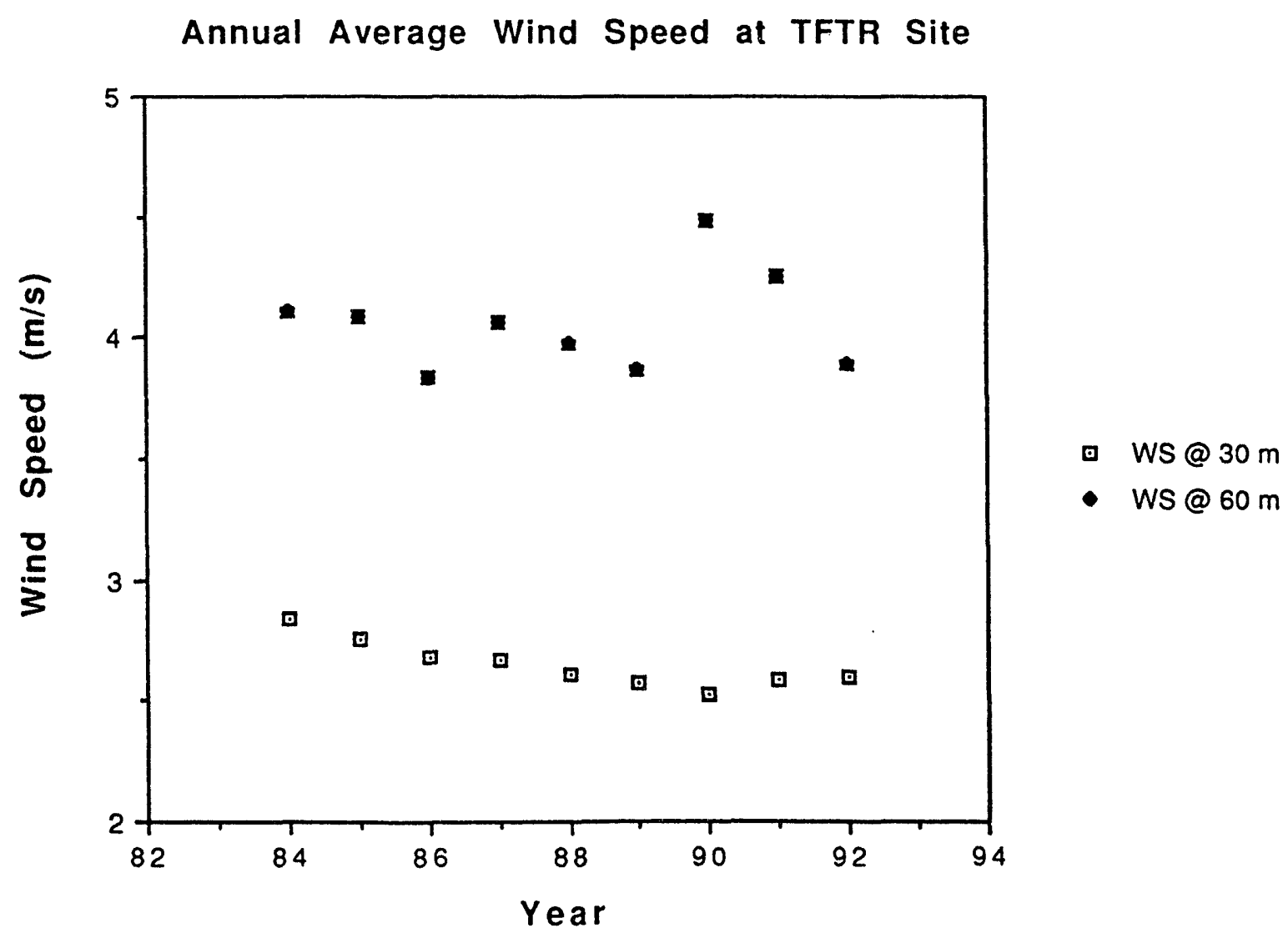

Figure 9. Annual Average Wind speed at TFTR Site, 1984 to 1992

101. 


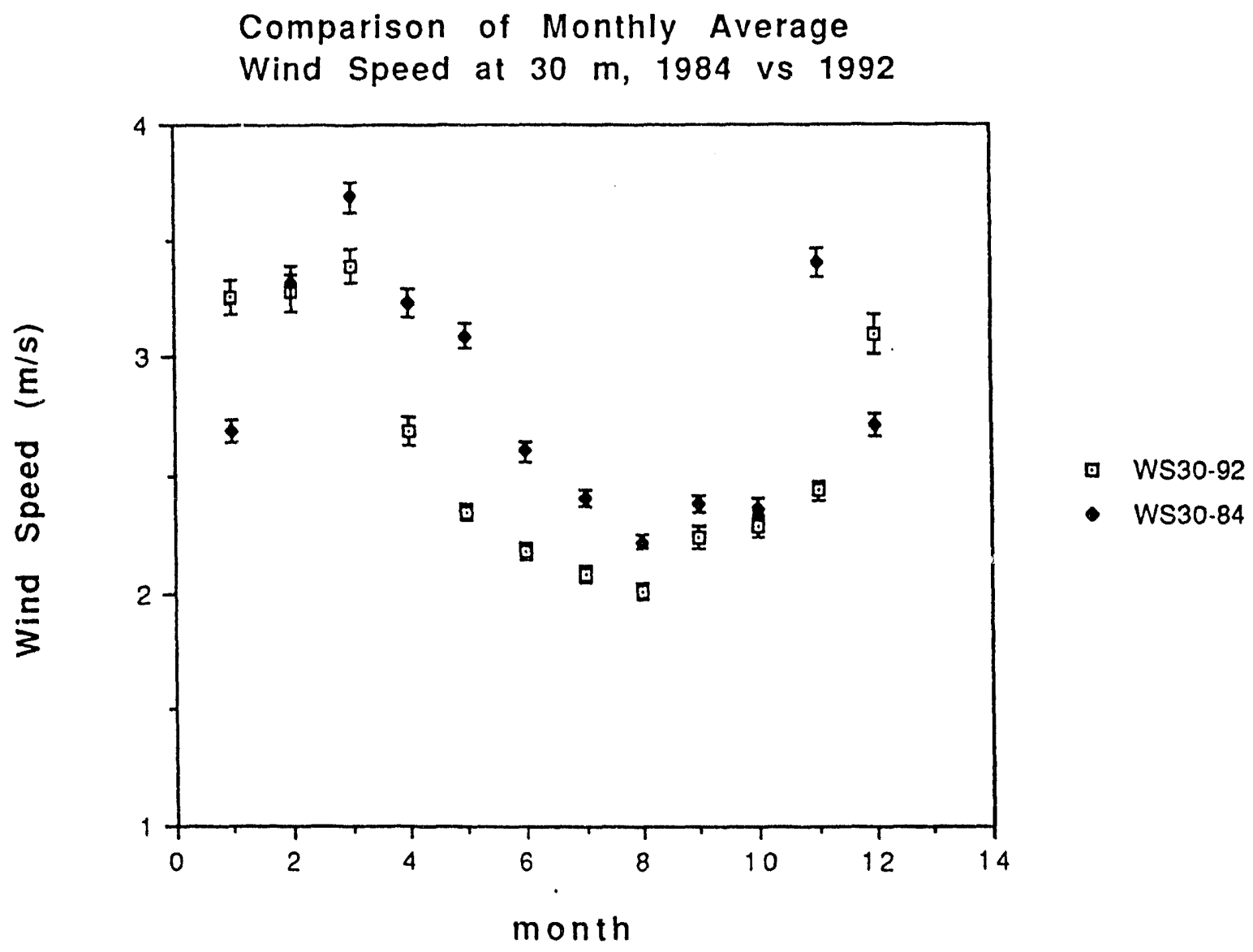

Figure 10. Comparison of monthly Average Wind Speed at $30 \mathrm{~m}, 1984$ to 1992 102. 


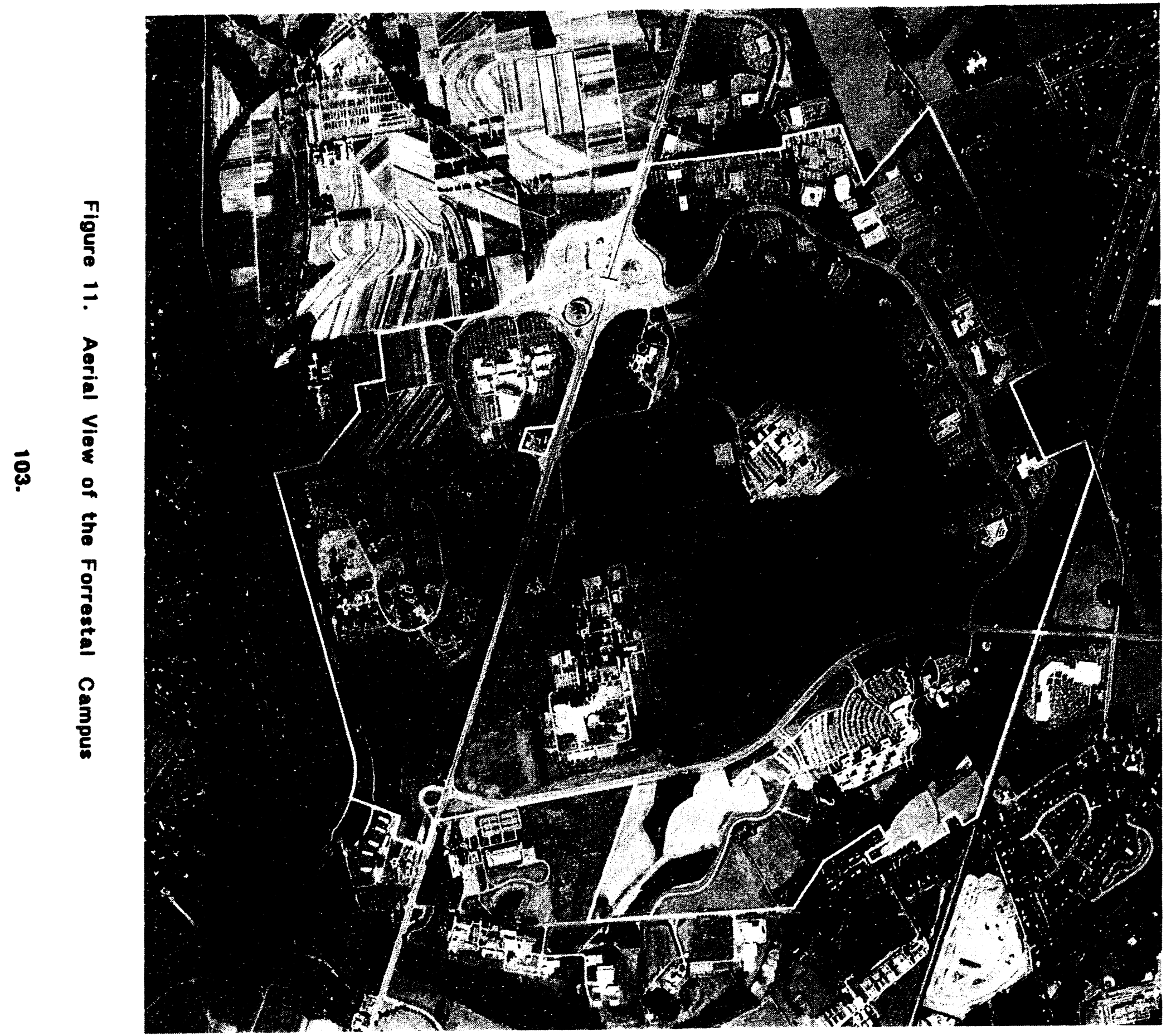




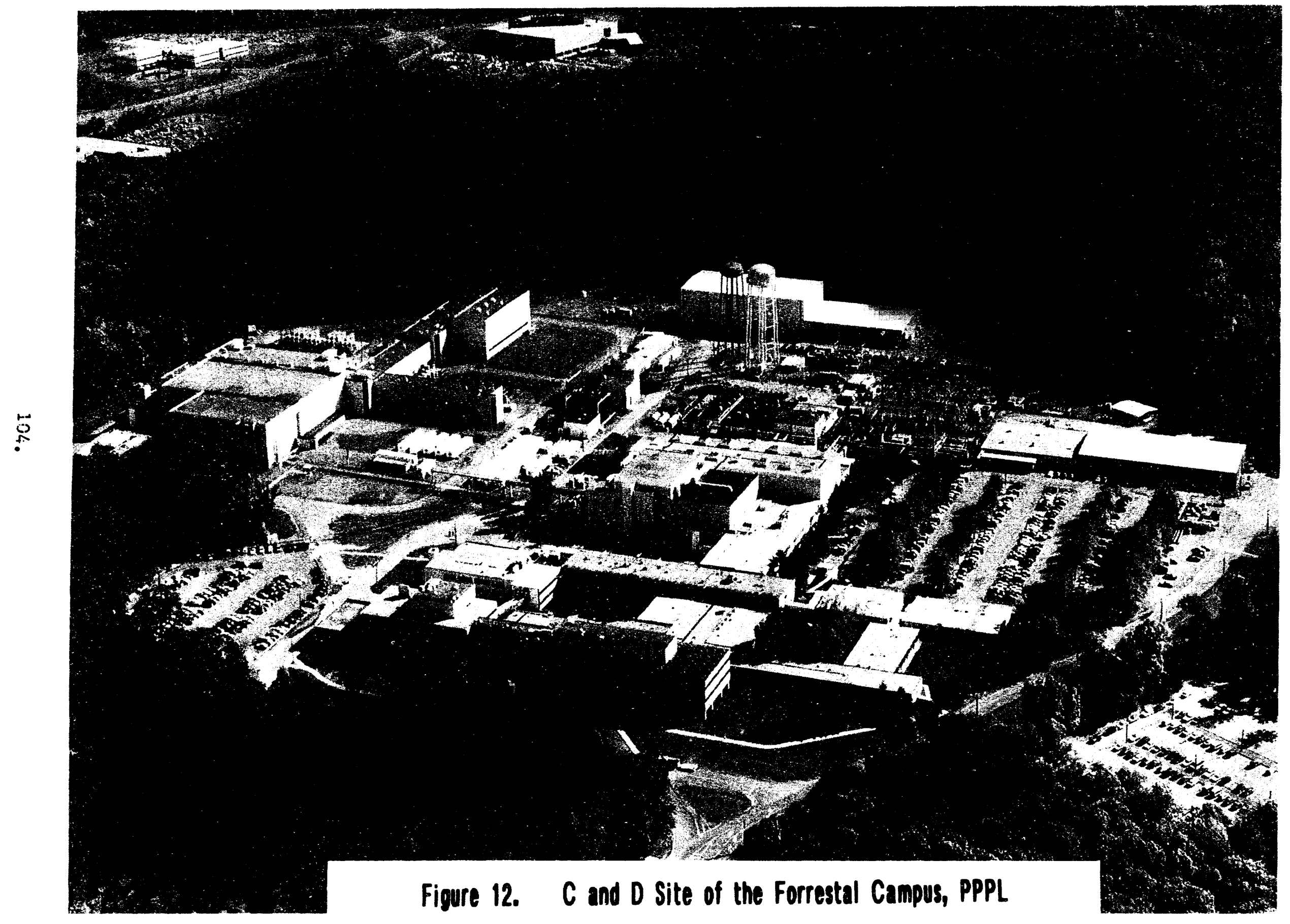




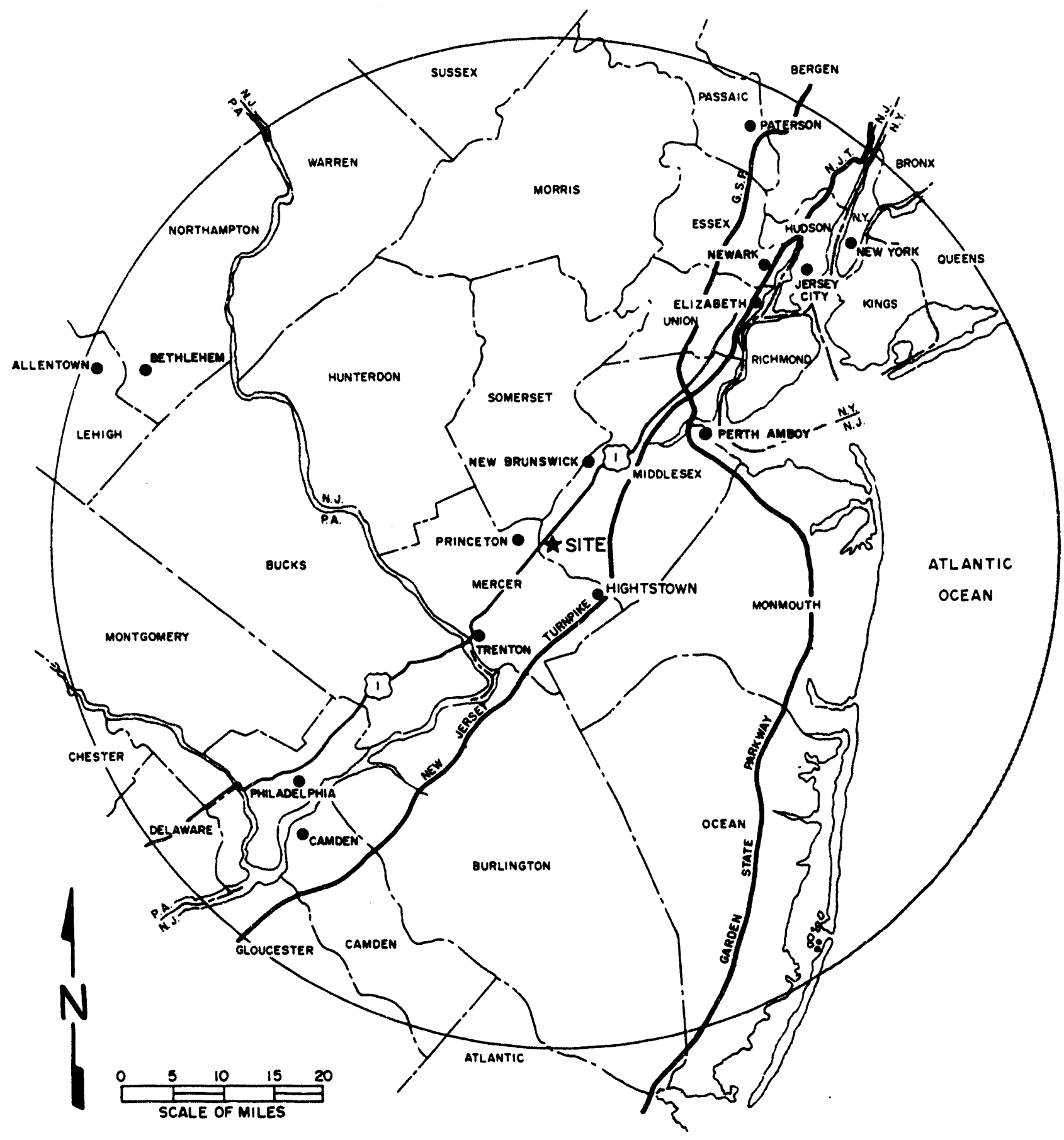

Region Surrounding the Proposed TFTR Site (50 Mile Radius Shown)

Figure 13. $80 \mathrm{~km}$ (50-mile) Radius of PPPL Site 


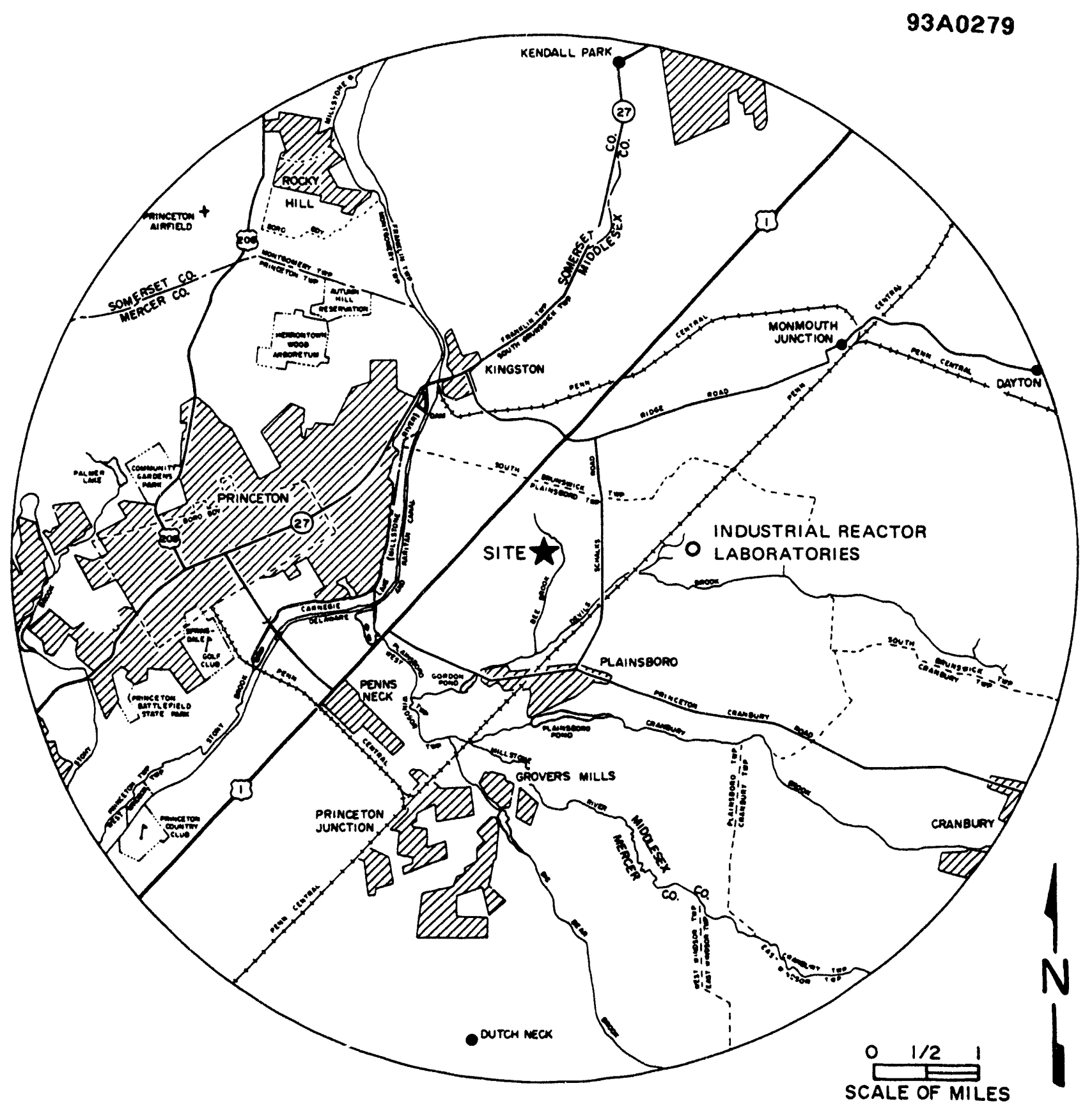

Immediate Site Environs

(5 Mile Radius Shown)

Figure 14. Immediate Site Vicinity (5 Mile Radius 


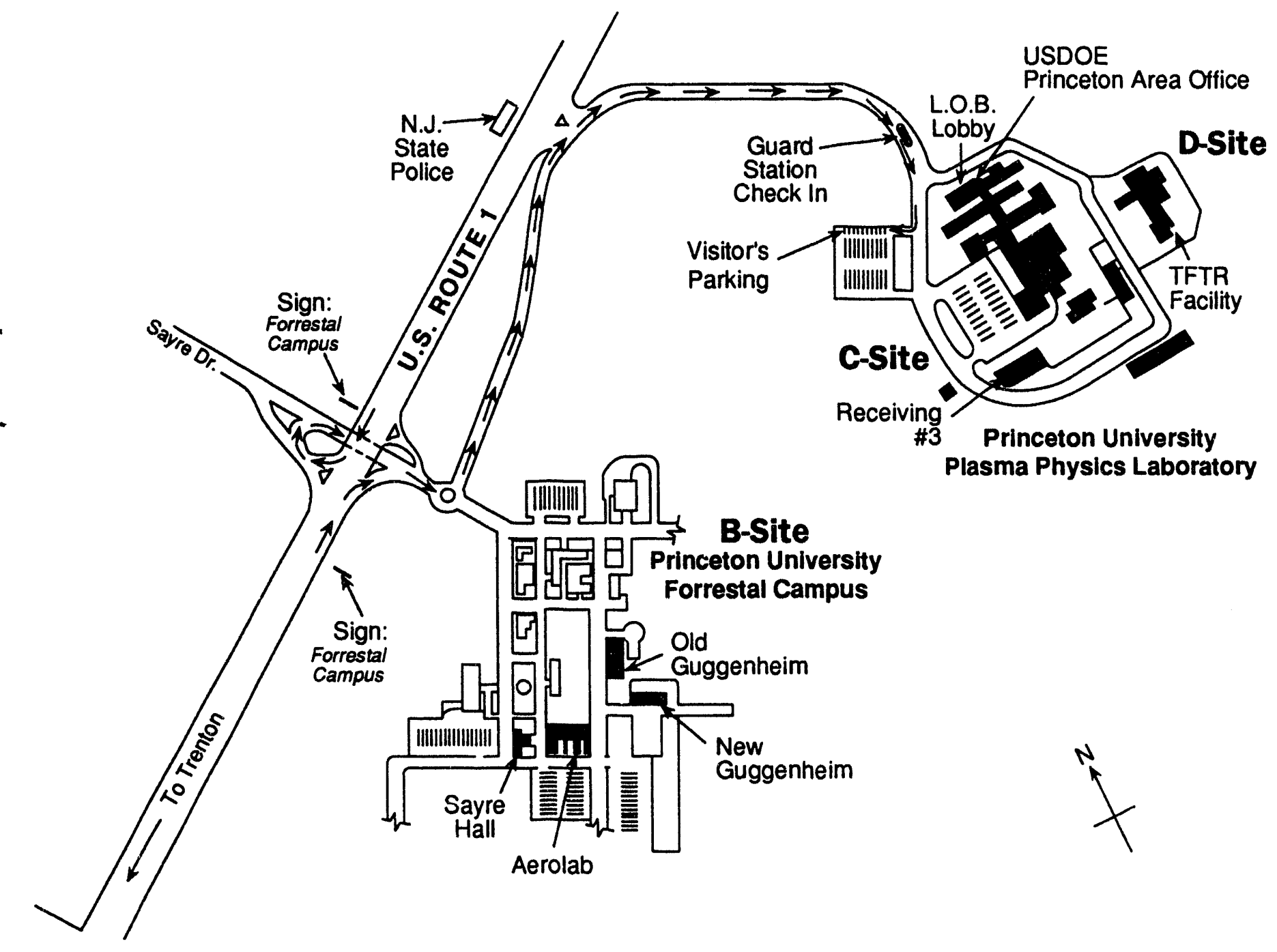

Figure 15. Layout of James Forrestal Campus

107. 


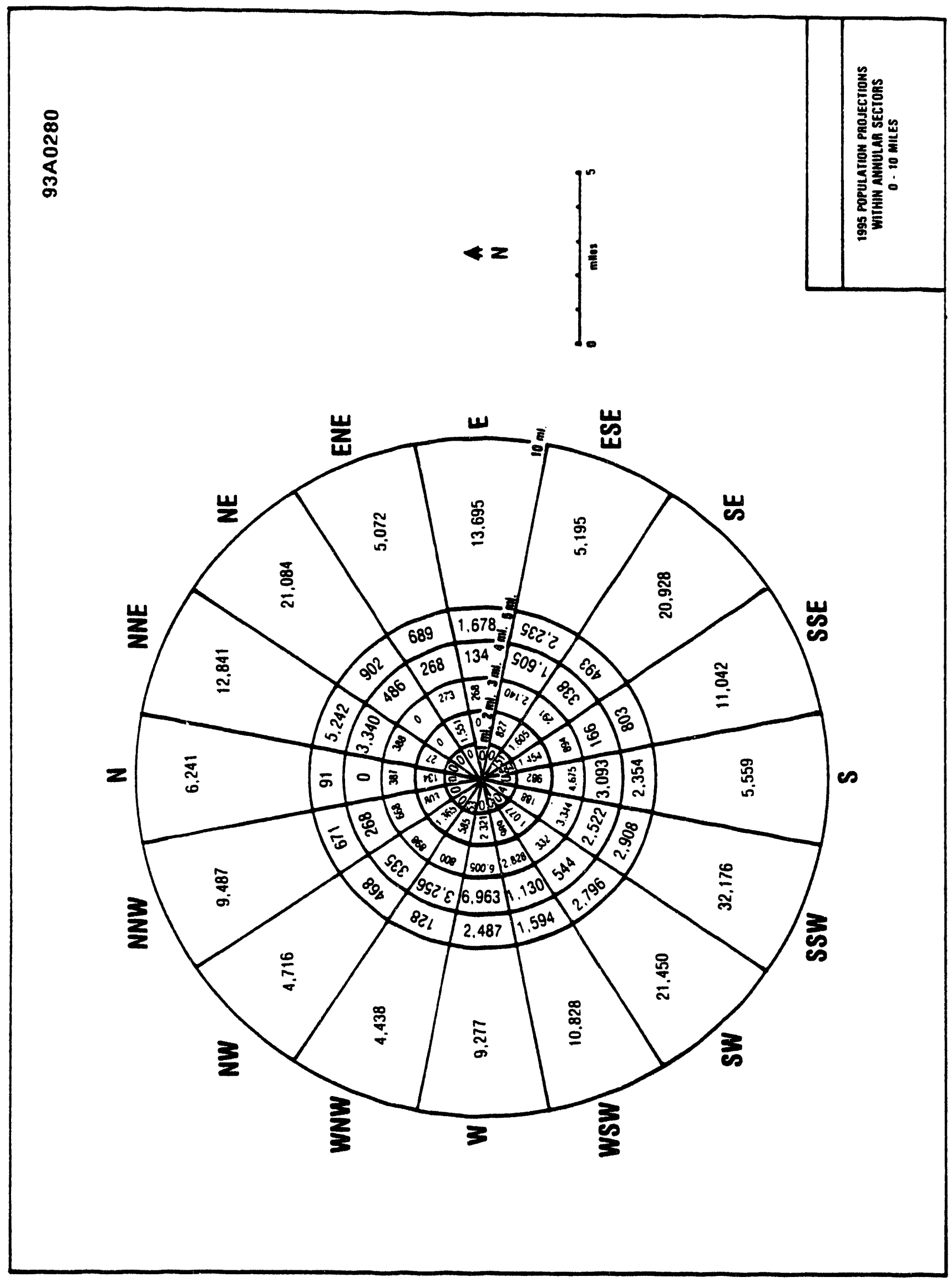

Figure 16. 1995 Population Proections Within Annular Sectors (0-10 Miles) 


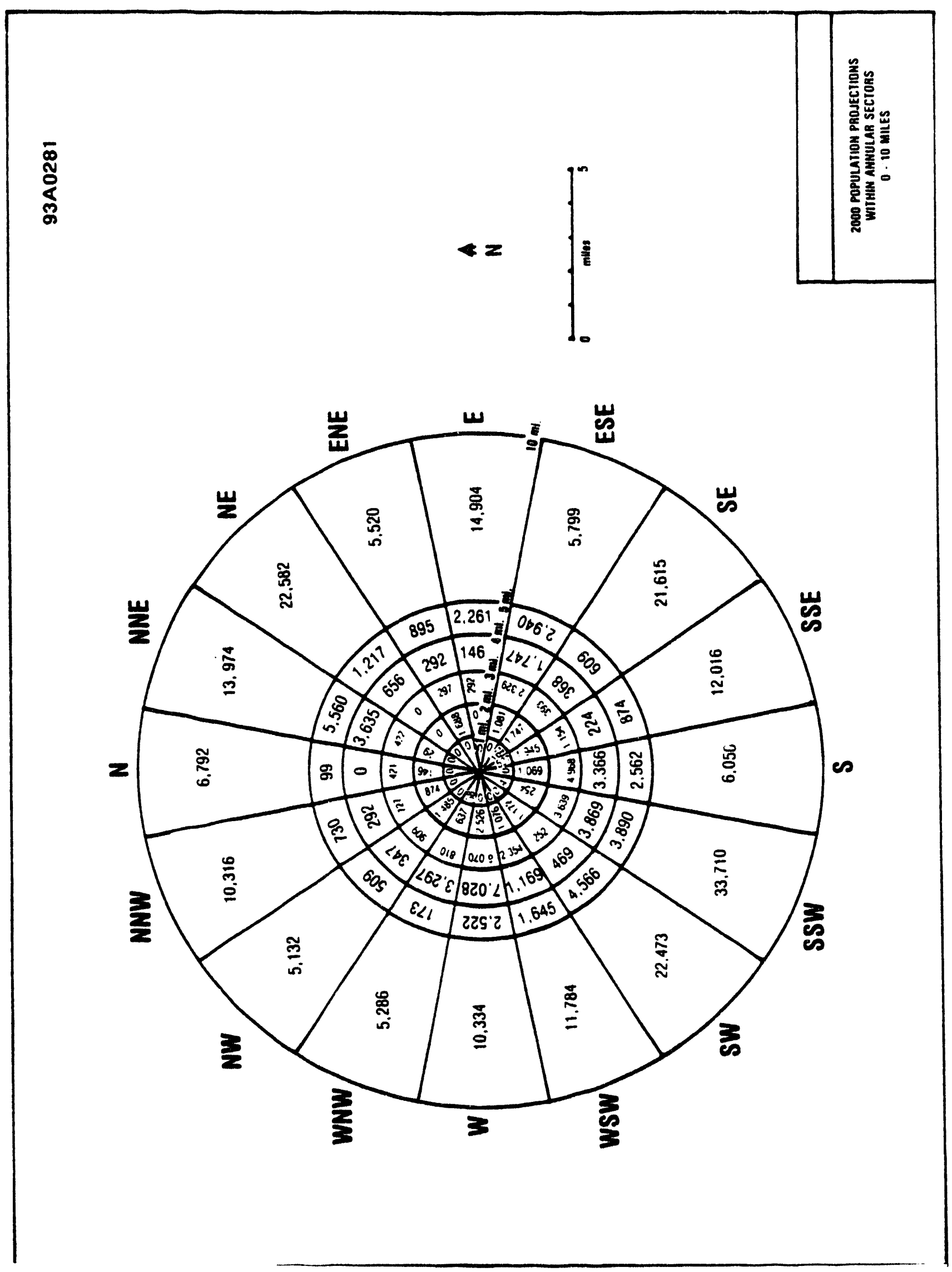

Figure 17. 2000 Population Projections Within Annula Sectors (0-10 Miles) 


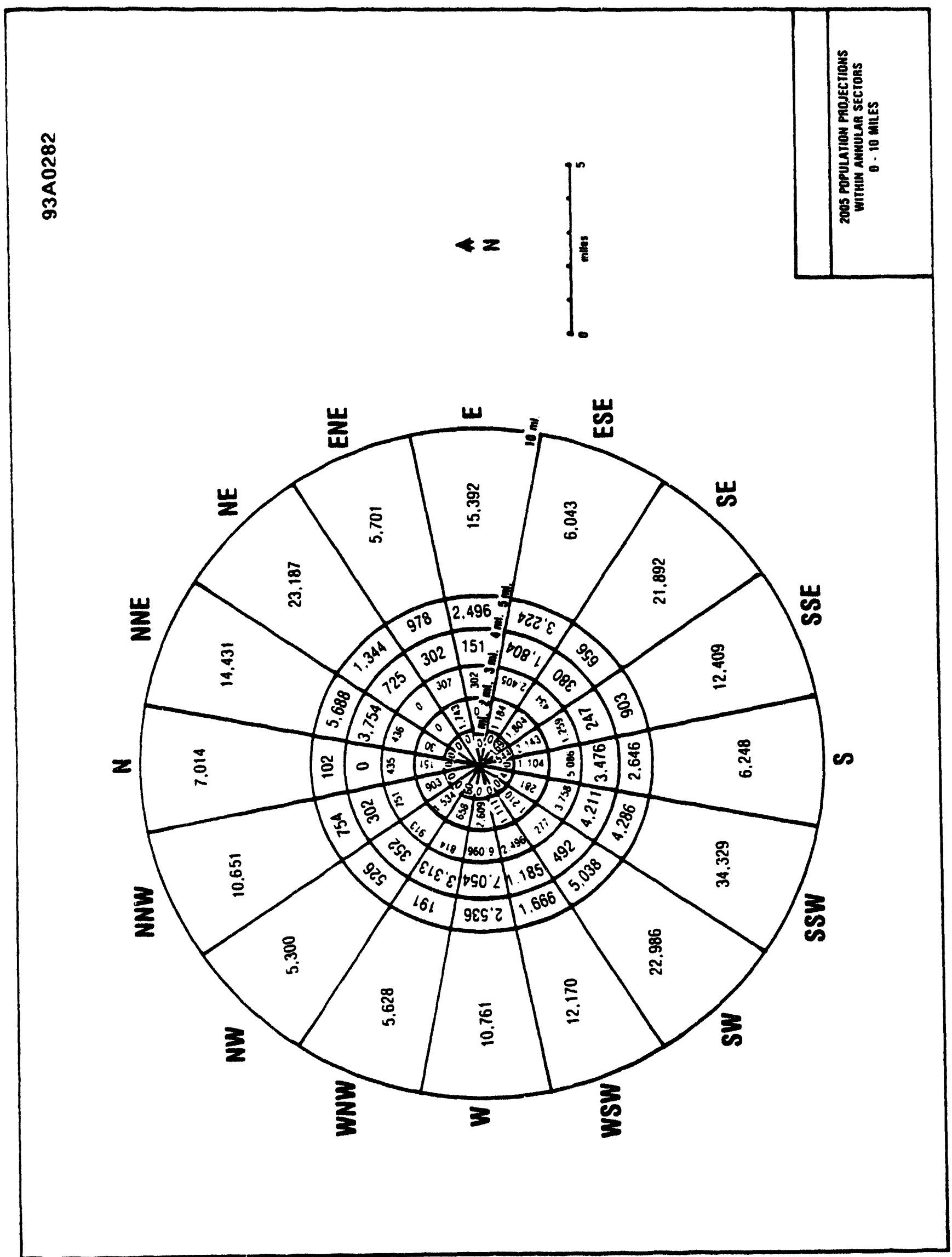

Figures 18. 2005 Population Projections Within Annular Sectors (0-10 Miles) 


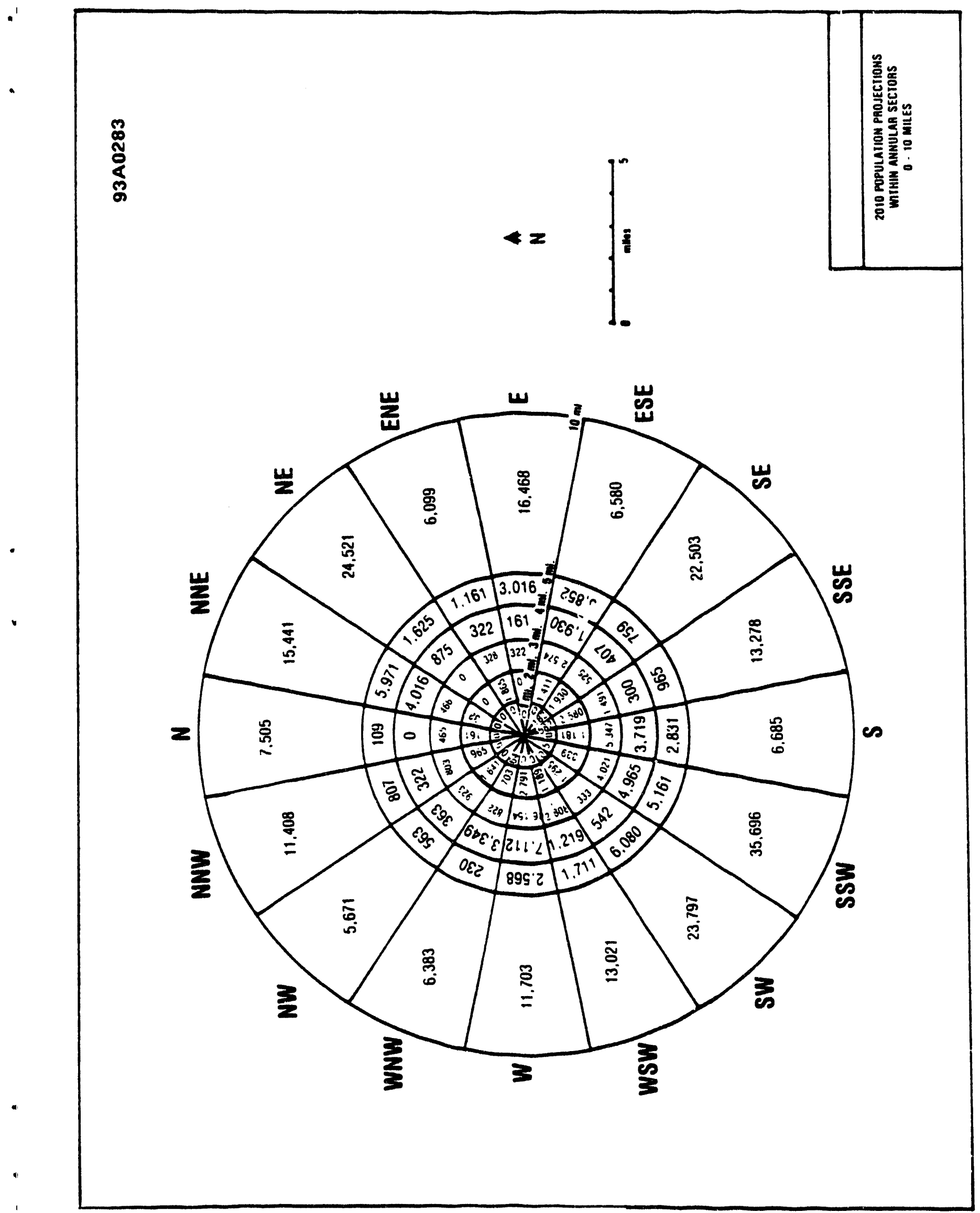

Figures 19. 2010 Population Projections Within Annular Sectors (0-10 Miles) 


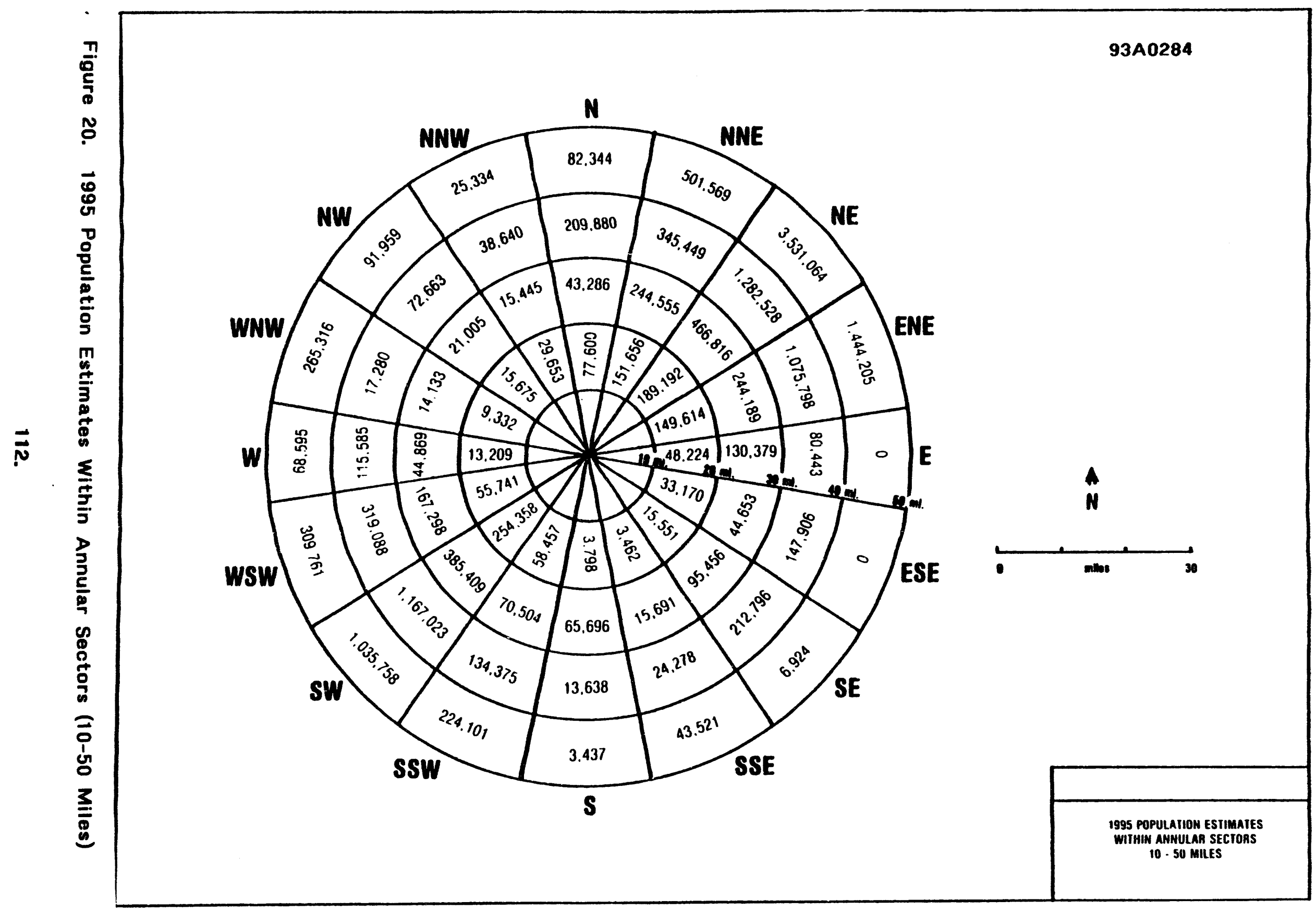




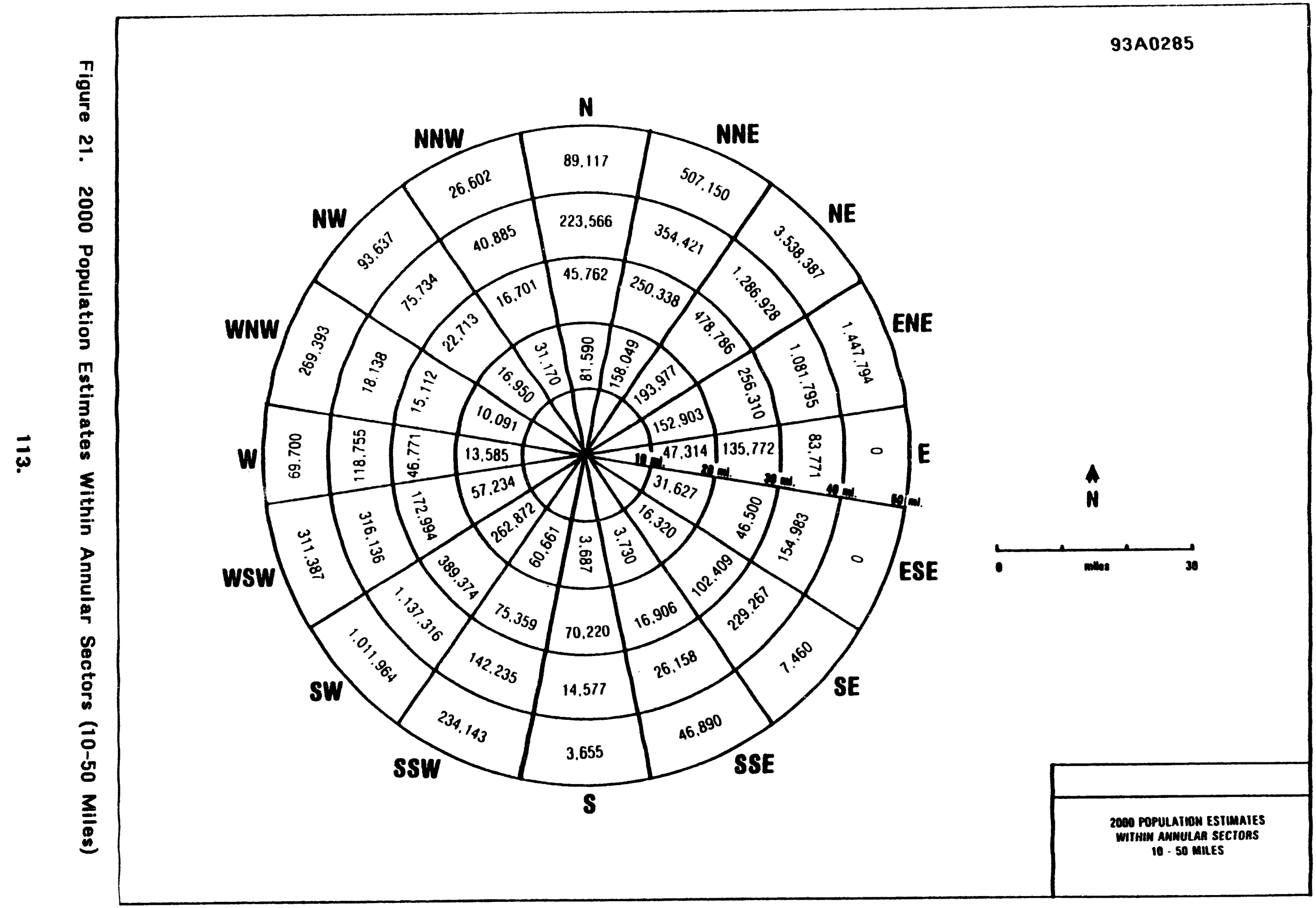




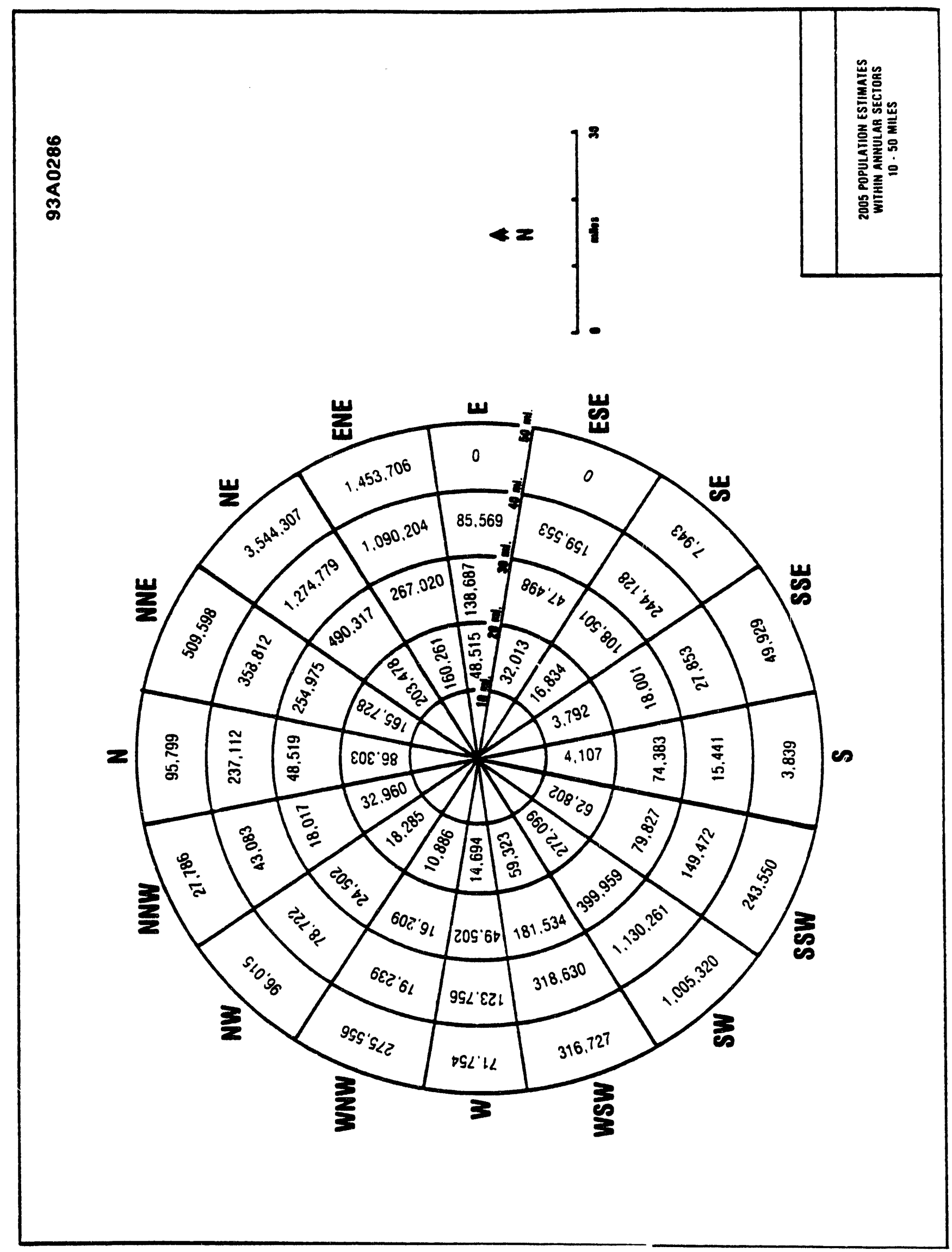

Figure 22. 2005 Population Estimates Within Annular Sectors (10-50 Miles) 


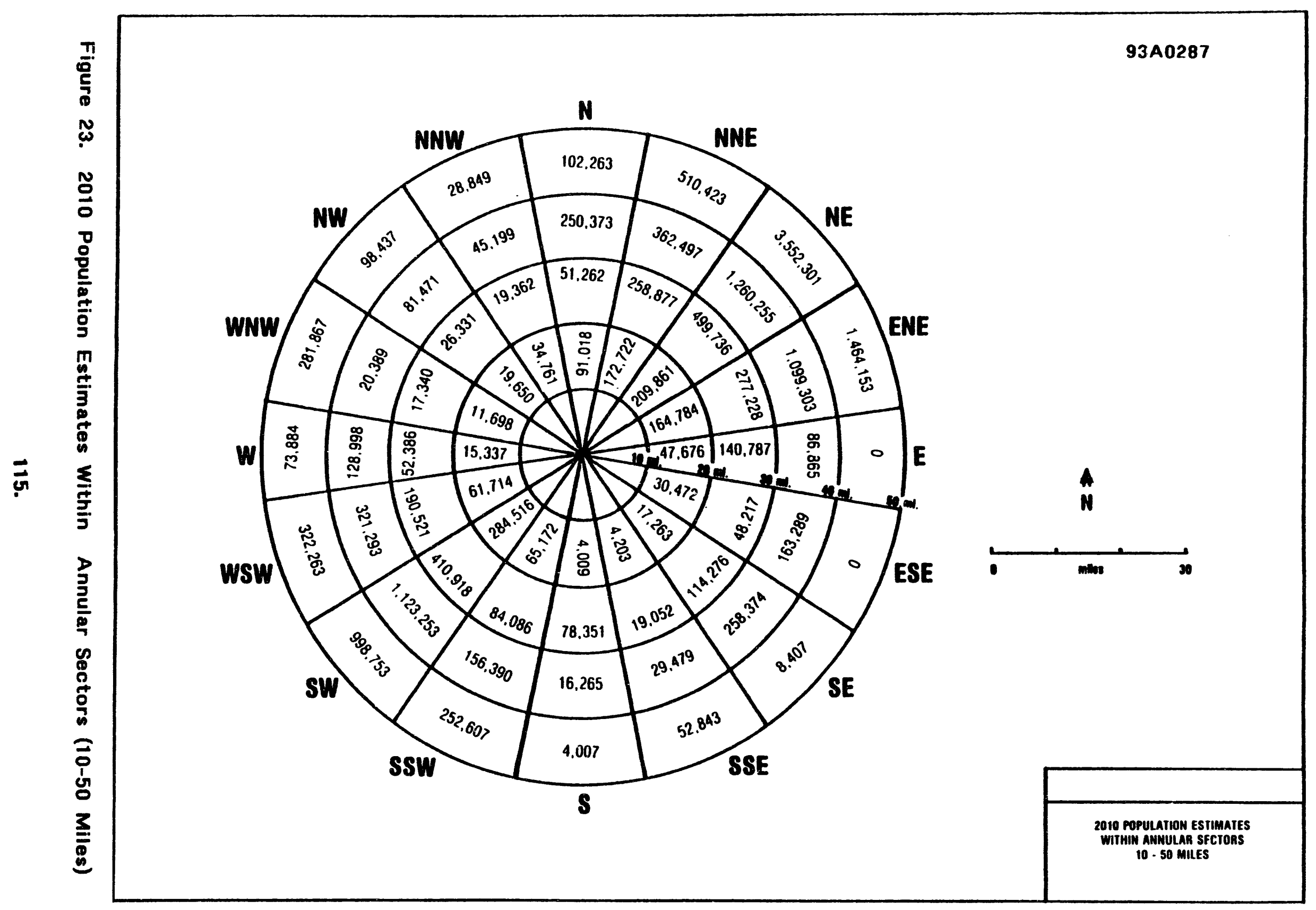




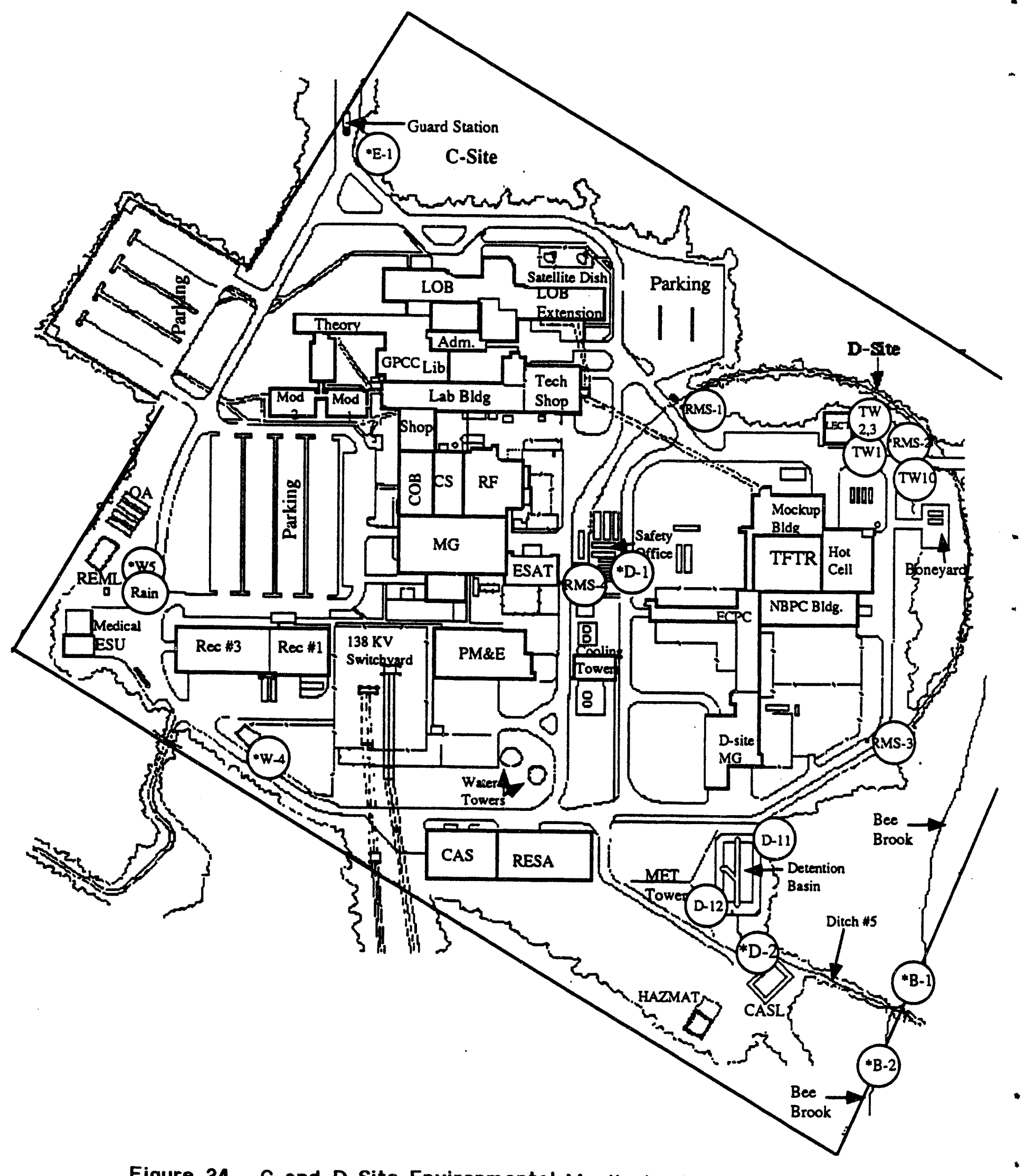

Figure 24. C-and D-Site Environmental Monitoring Locations 


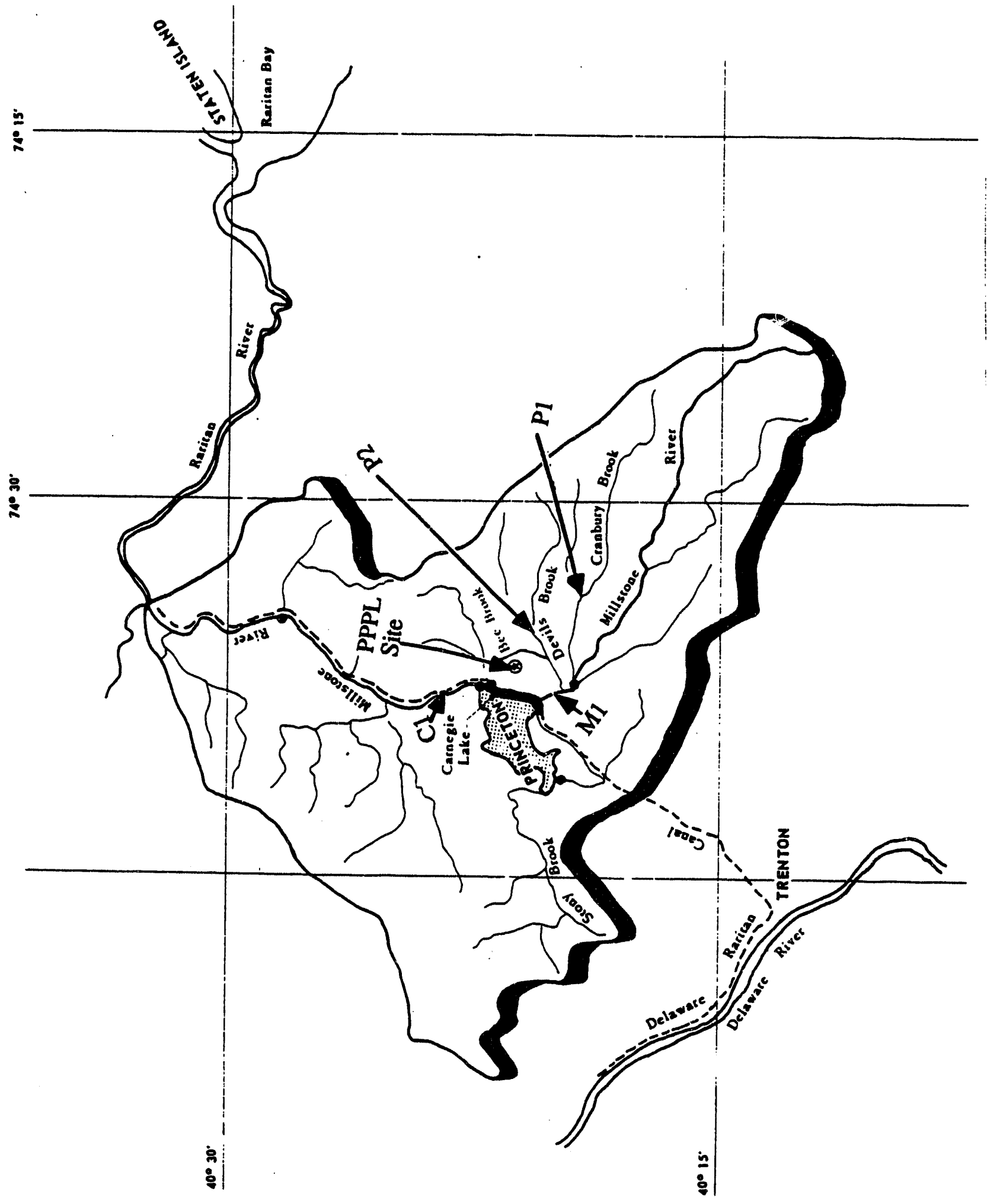

$\Longrightarrow(\mathrm{z})$

Figure 25. Millstone River Basin Offsite Surface Water Sample Locations 


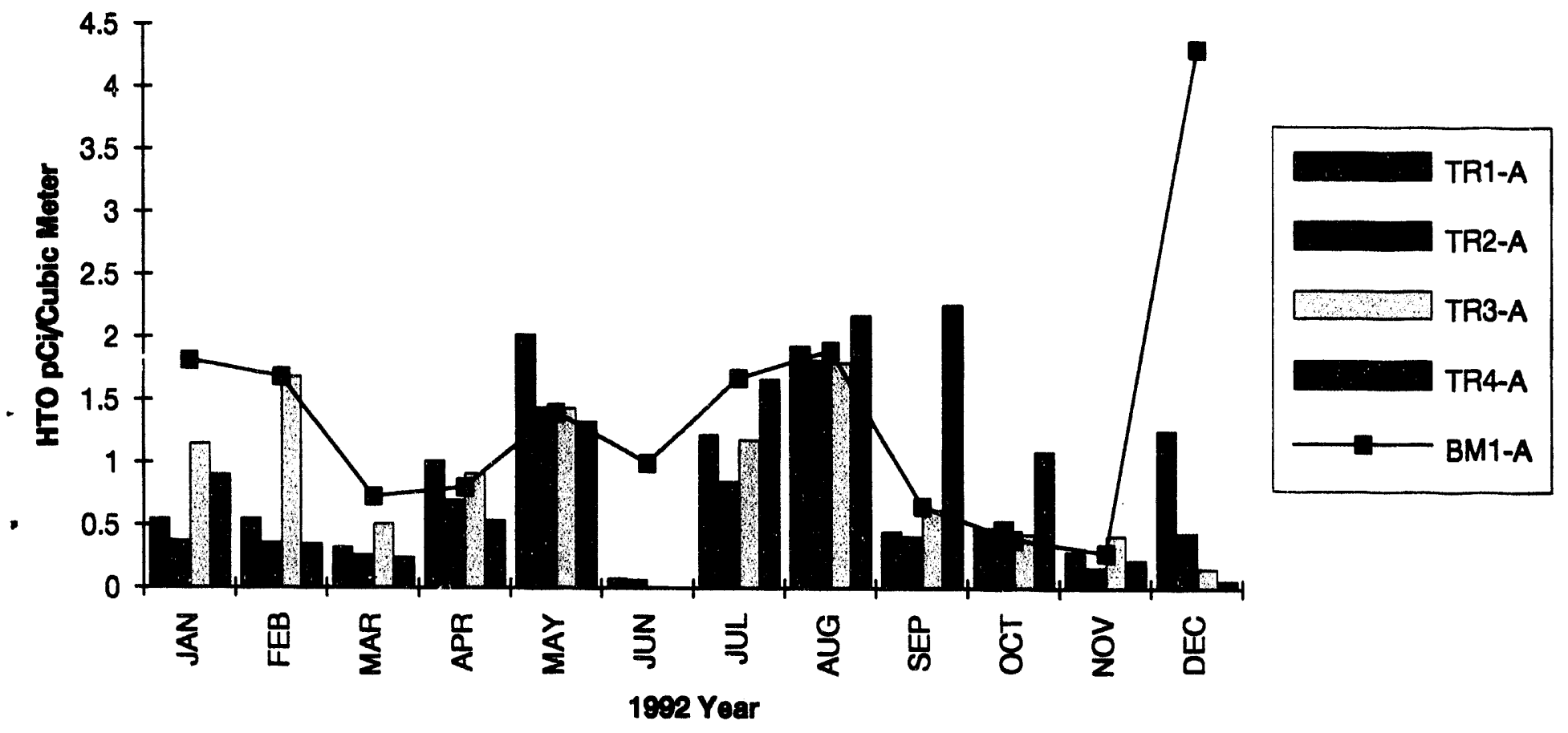

Figure 26. 1992 Air Tritium (HTO) - TR 1-A to TR 4-A

118. 


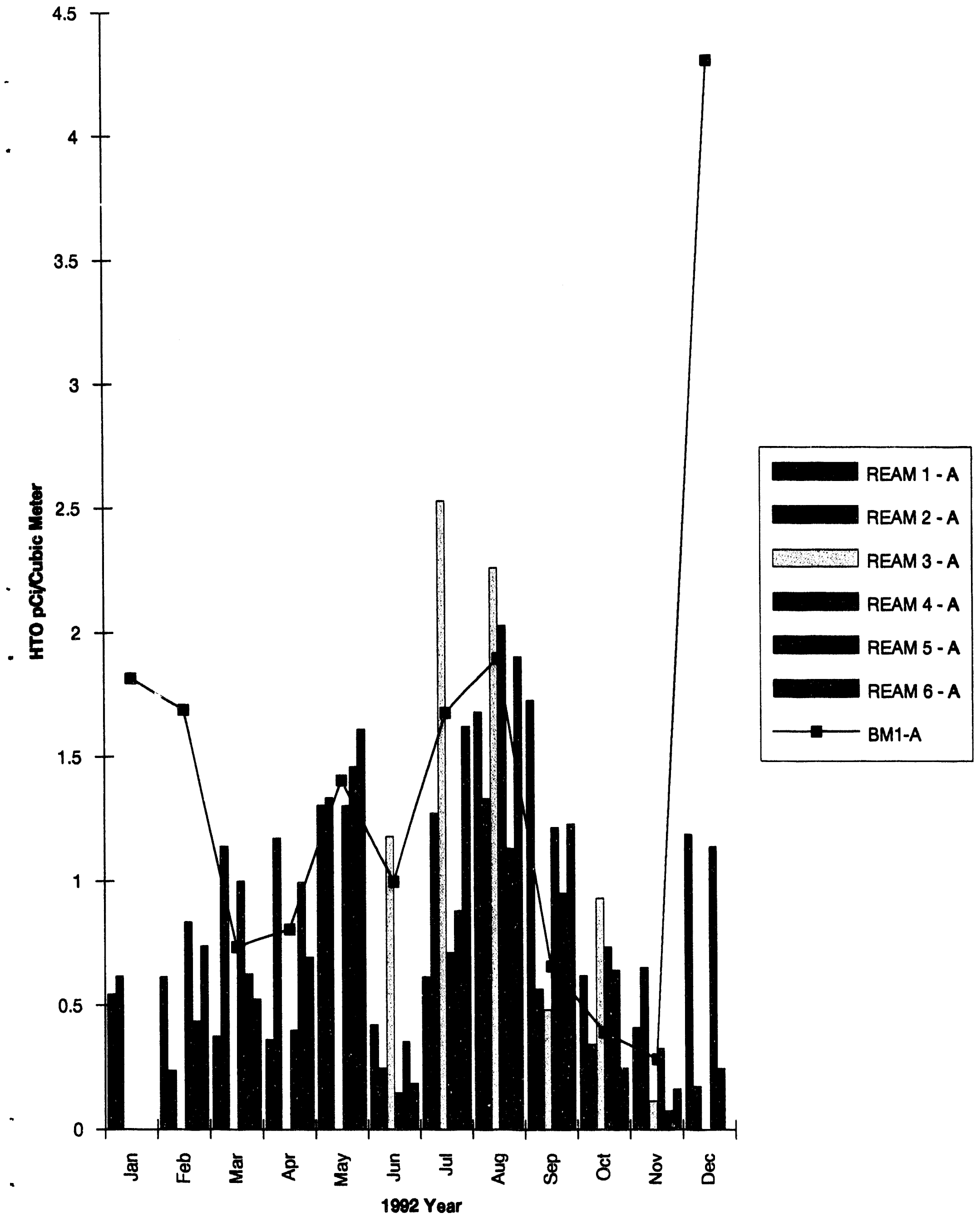

Figure 27. 1992 Air Tritium (HTO) - REAM 1-A to REAM 6-A 


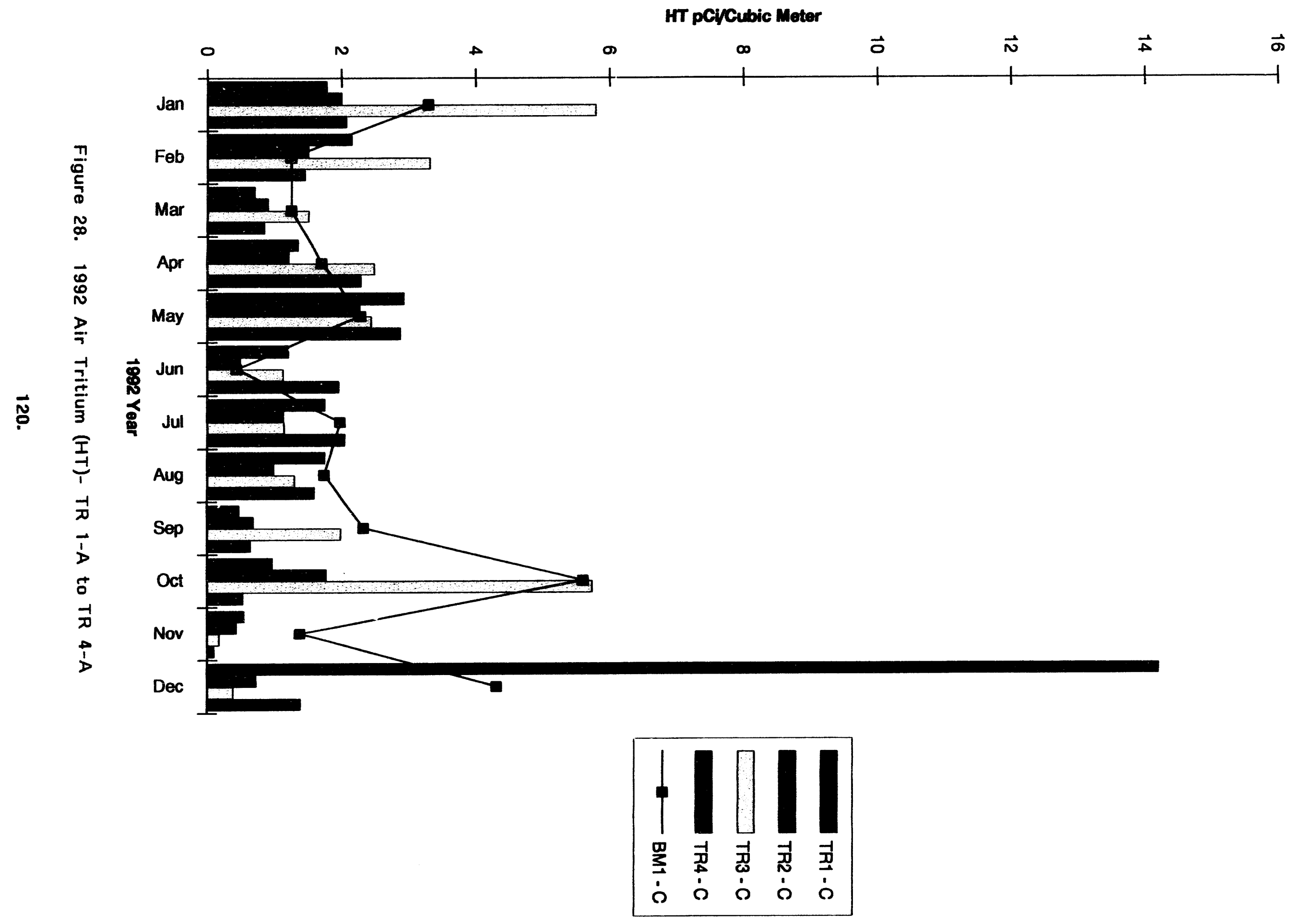




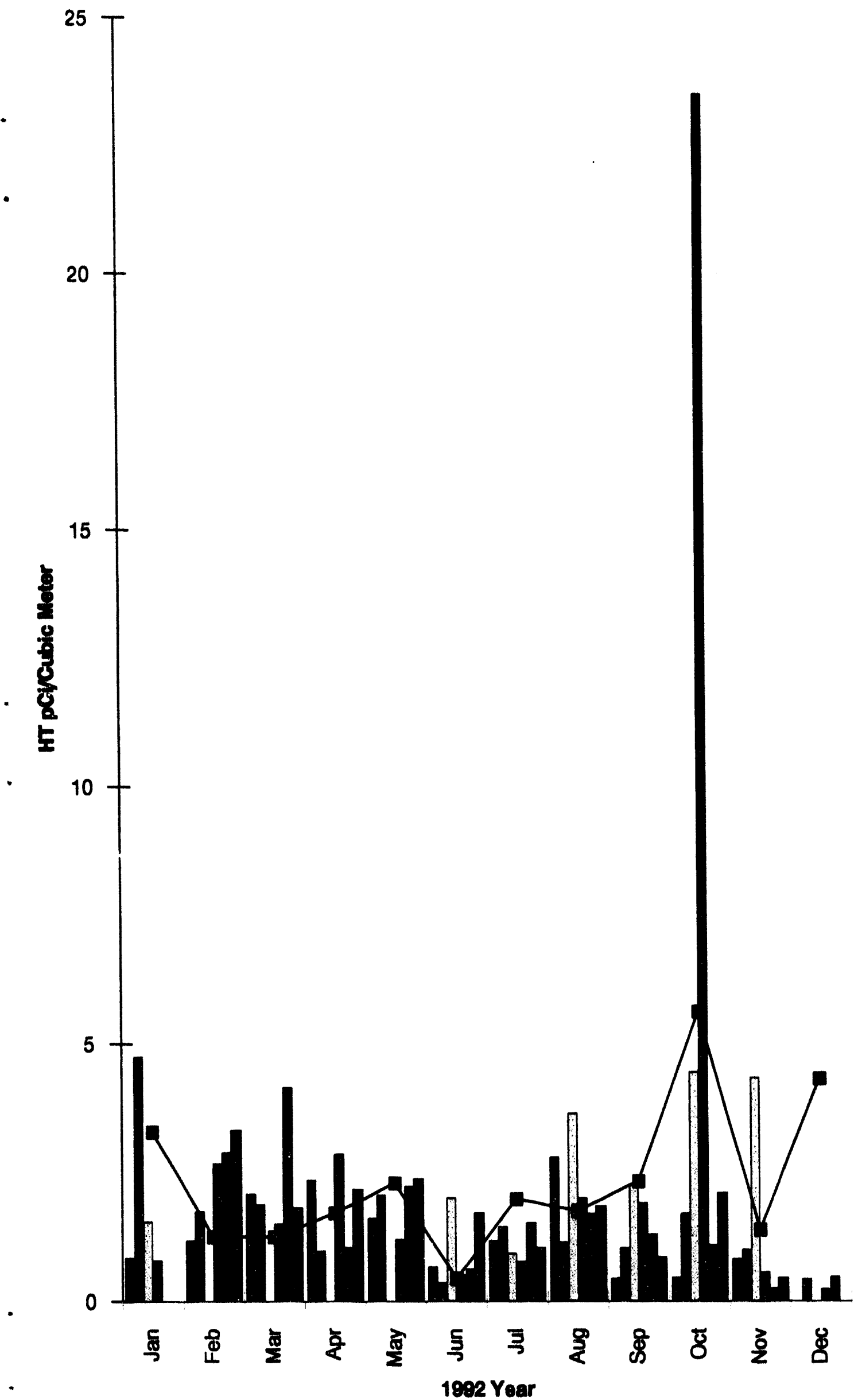

Figure 29. 1992 Air Tritium (HT) - REAM 1-C to REAM 6-C

121. 

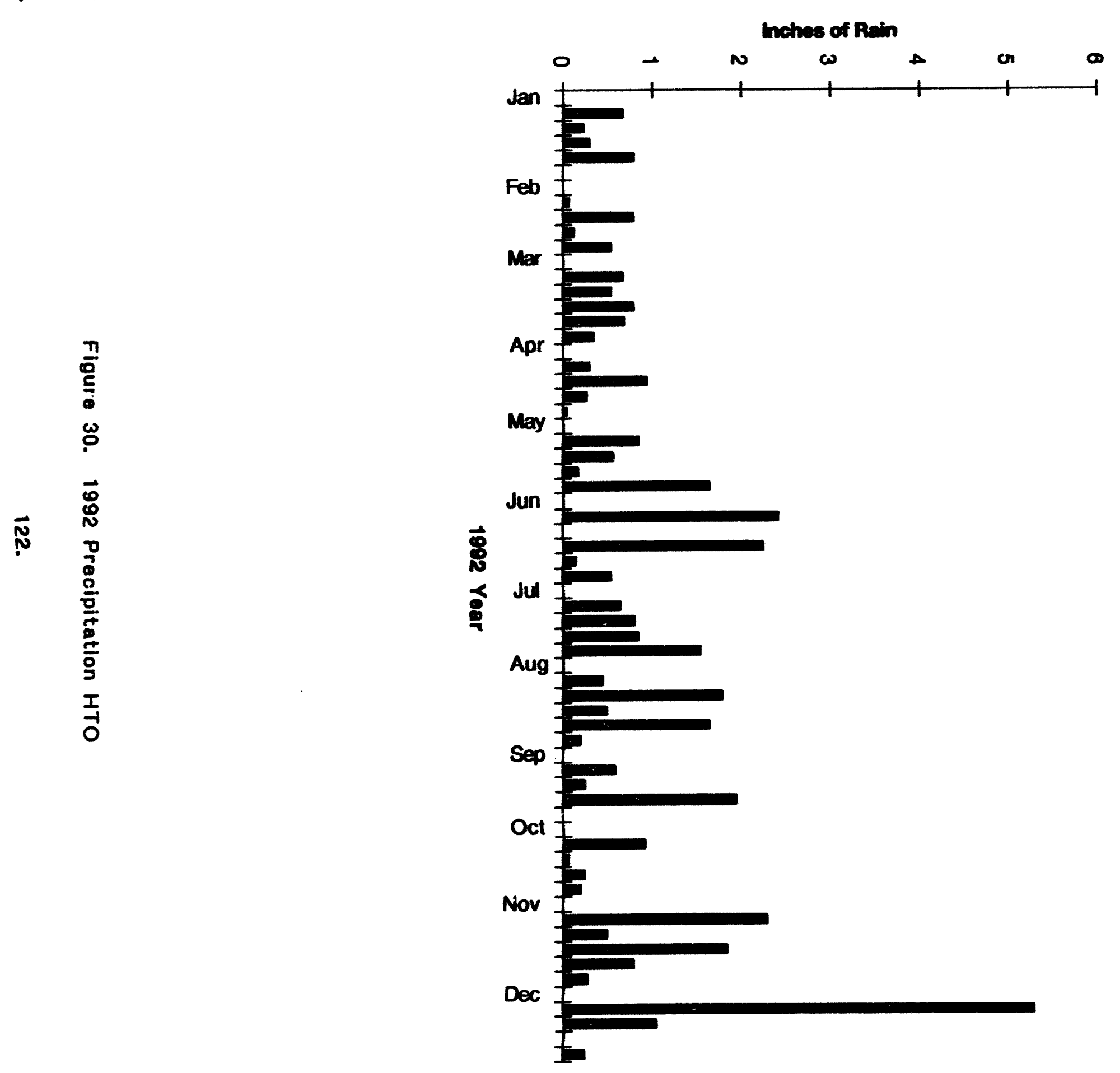

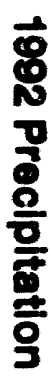


1992 Rain Water HTO

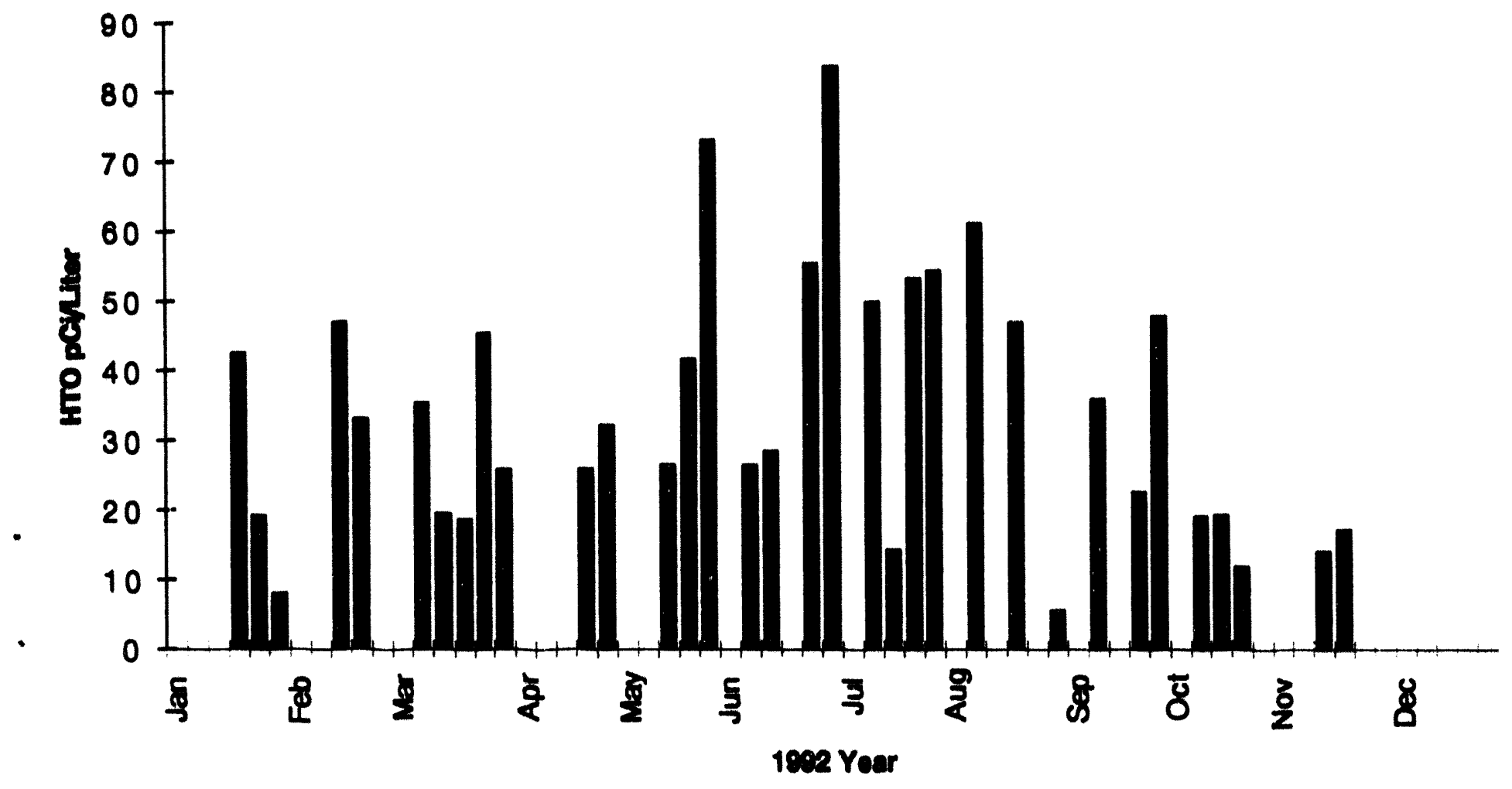

Figure 31. 1992 Rain Water HTO

123. 


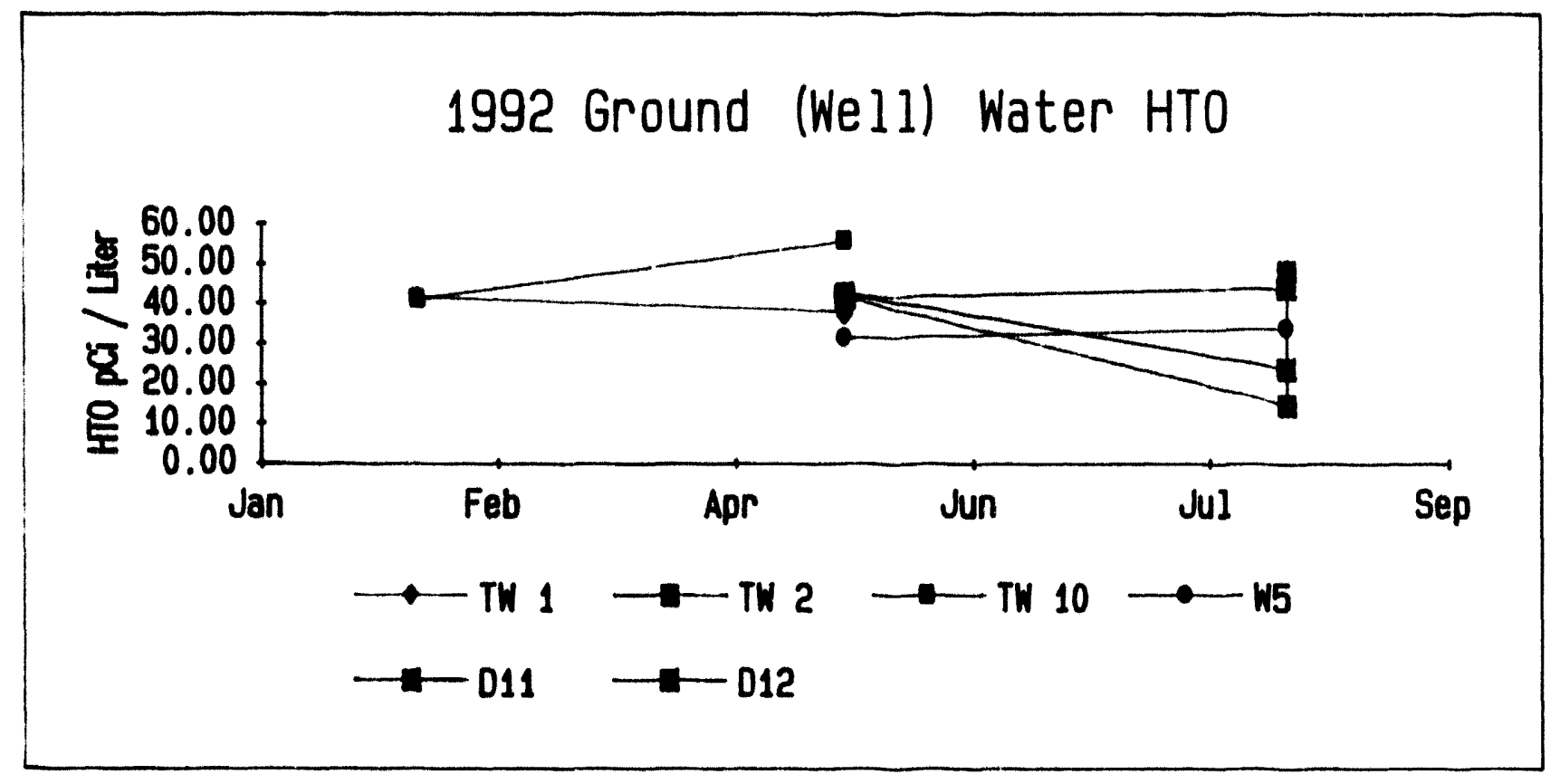

Figure 32. 1992 Ground (Well) Water HTO

124. 


\begin{tabular}{cccccc}
\hline Date & B1 & B2 & $D 1$ & $D 2$ & Baseline \\
\hline Jan-92 & 35.83 & 33.17 & 38.14 & 43.81 & \\
Feb-92 & 41.88 & 44.53 & 49.93 & 44.19 & \\
Mar-92 & 41.15 & 40.14 & 41.23 & 39.77 & \\
Apr-92 & 32.44 & 47.95 & 45.72 & 49.54 & 55.57 \\
May-92 & 32.16 & 36.72 & 39.07 & 39.1 & 49.73 \\
Jun-92 & 41.38 & 48.19 & 20.4 & 38.53 & 34.26 \\
Jul-92 & 43.04 & 54.35 & 82.74 & 61.11 & 53.58 \\
Aug-92 & 41.09 & 39.92 & 34.46 & 46.89 & 36.84 \\
Sep-92 & 16.39 & 40.59 & 43.42 & 37.57 & 37.15 \\
Oct-92 & & & & & \\
Nov-92 & 58.33 & 40.49 & 33.59 & 39.37 & 23.4 \\
Dec-92 & & & &
\end{tabular}

\section{Tritlum in Surface Water}

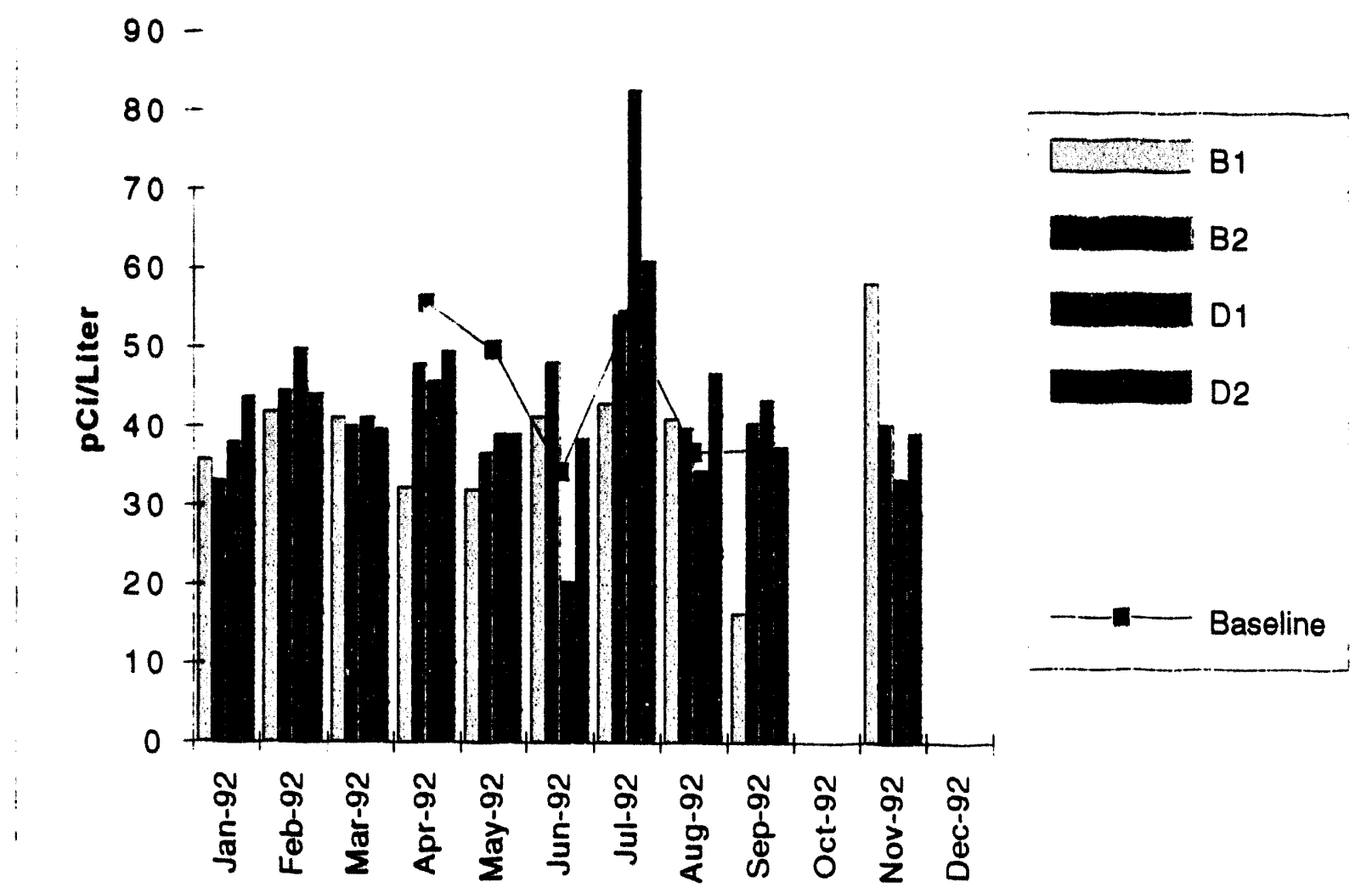

Figure 331992 Tritium (HTO) Concritrsions in Surface Water for Stations Bee Brook $(B 1, B 2$,$) D site (D1), Basin Discharge(D2), and Baseline$ 


\begin{tabular}{cccccc}
\hline Date & E1 & $M 1$ & $P 1$ & $P 2$ & Baseline \\
\hline Jan-92 & 49.45 & 35.15 & 42.66 & 39.58 & \\
Feb-92 & 42.09 & 26.1 & 45.44 & 29.76 & \\
Mar-92 & 51.6 & 42.76 & 51.47 & 48.02 & \\
Apr-92 & 39.28 & 44 & 50.54 & 54.34 & 55.57 \\
May-92 & 42.79 & 46.62 & 29.76 & 46.35 & 49.73 \\
Jun-92 & 36.63 & 32.15 & 40.69 & 30.4 & 34.26 \\
Jul-92 & 76.7 & 47.16 & 60.61 & 44.04 & 53.58 \\
Aug-92 & 35.2 & 63.81 & 53.98 & 33.59 & 36.84 \\
Sep-92 & 35.33 & 39.61 & 42.12 & 30.55 & 37.15 \\
Oct-92 & & & & & \\
Nov-92 & 41.8 & & 32.93 & 26.57 & 23.4 \\
Dec-92 & & 12.46 & & & \\
\hline
\end{tabular}

All measurement values are in $\mathrm{pCi} / \mathrm{Liter}$.

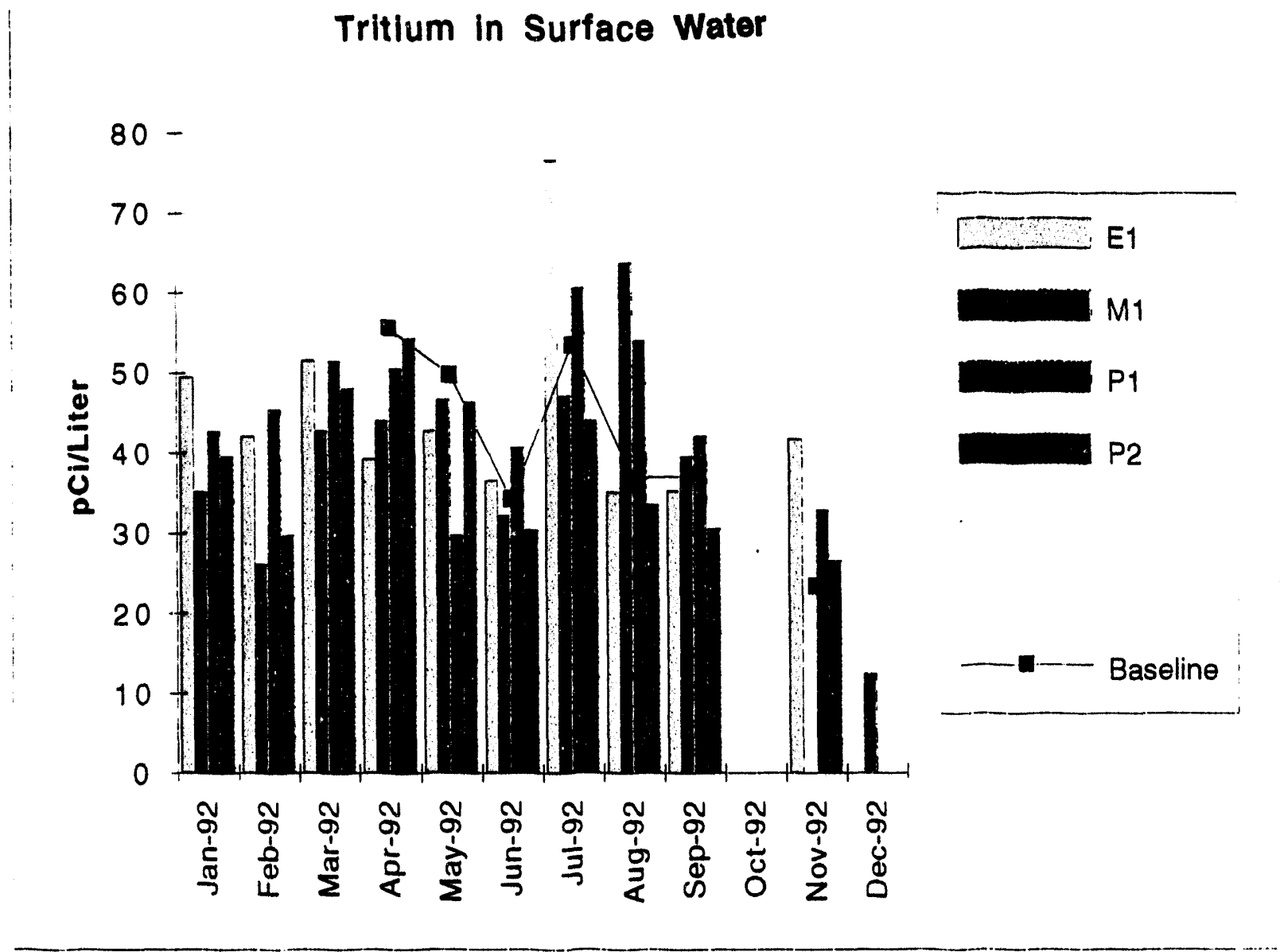

Figure 34. 1992 Tritium (HTO) Concentration in Surface Water for Stations Elizabethtown Water (E1), Millstone River (M1), Devils Brook (P1,P2) 


\section{Tritium (HTO) in Biota}

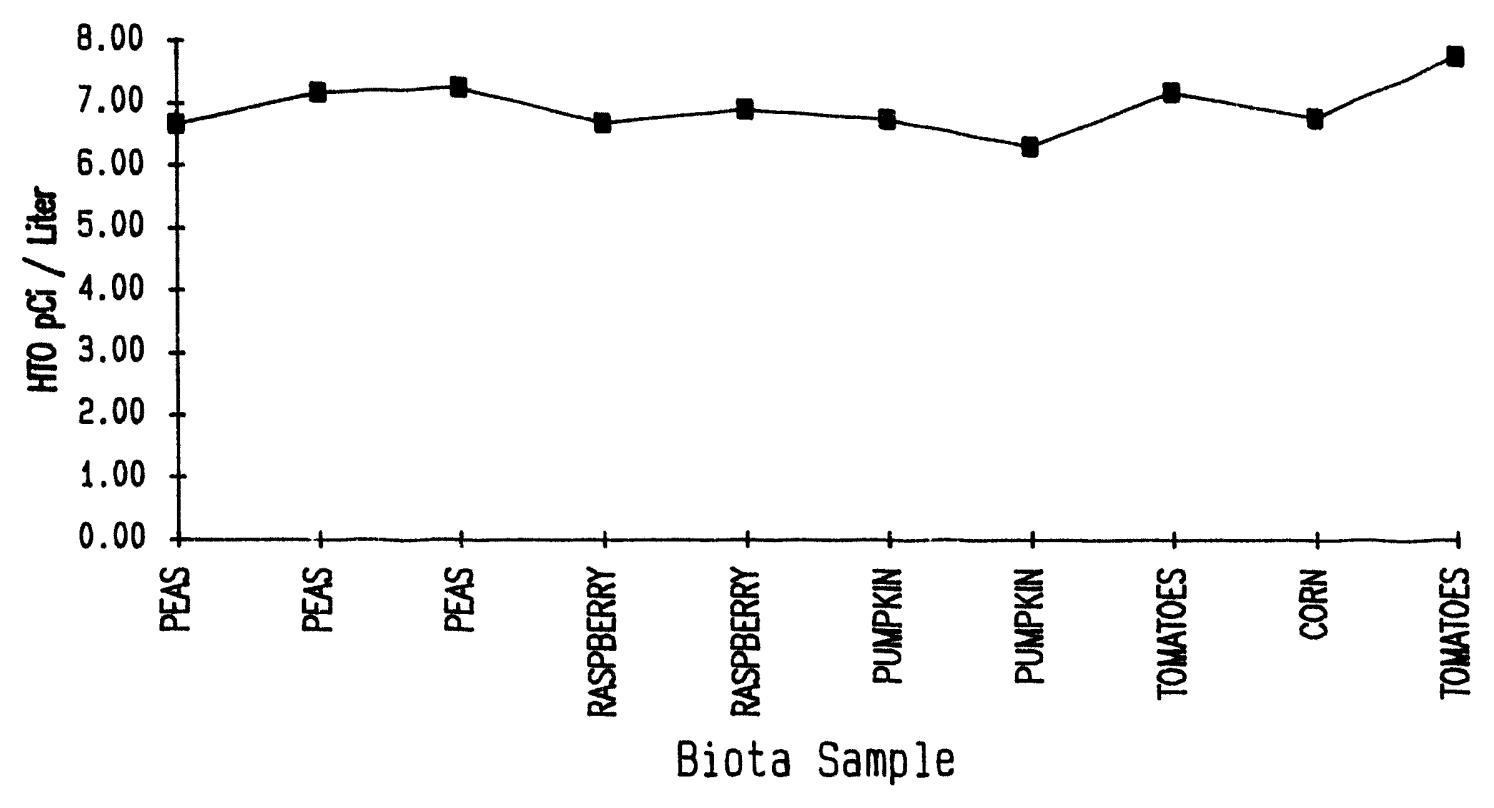

Figure 35. 1992 Tritium (HTO) in Biota 


\section{Soil Tritium}

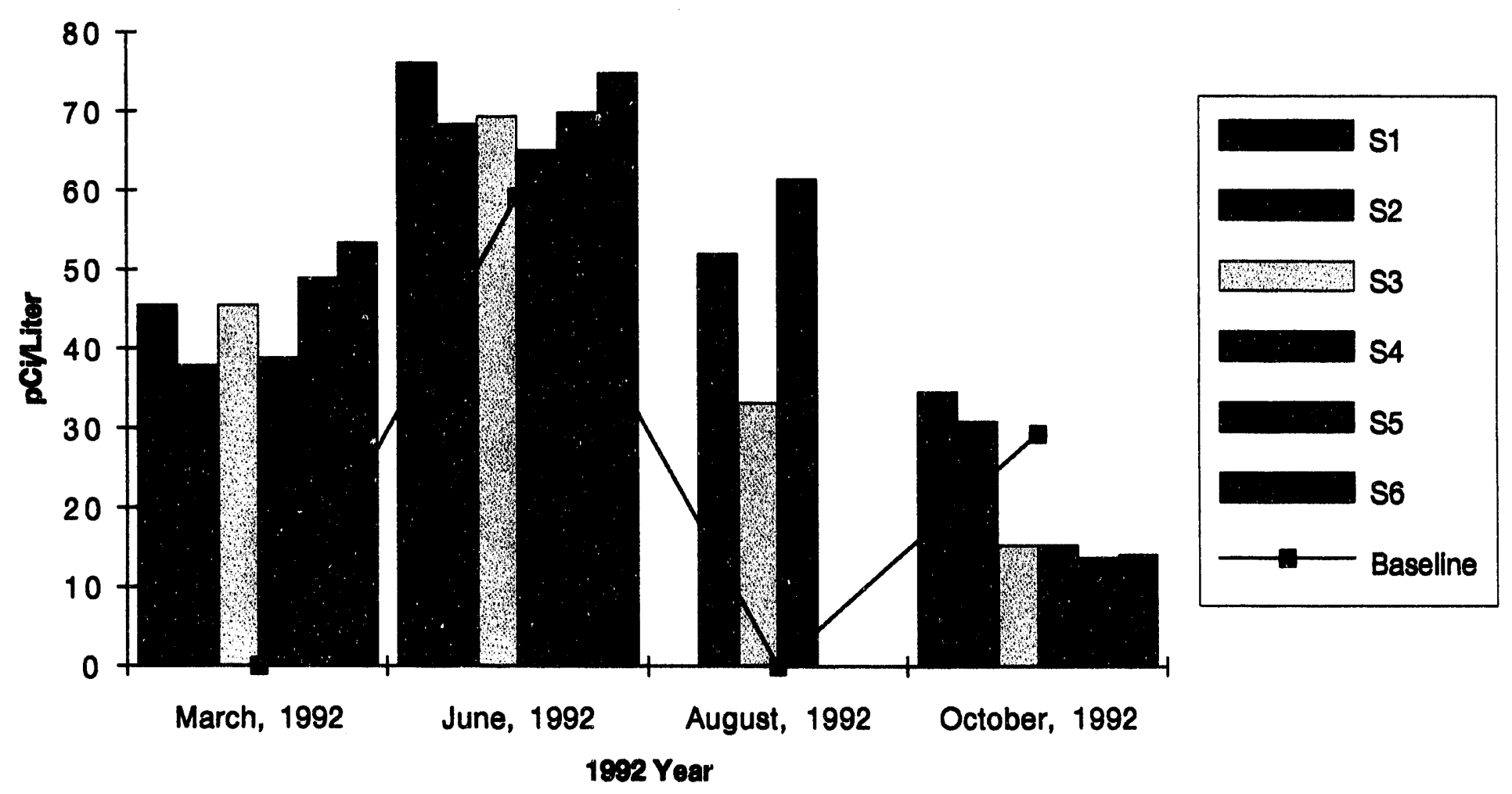

Figure 36. 1992 Soil Tritium (HTO) 


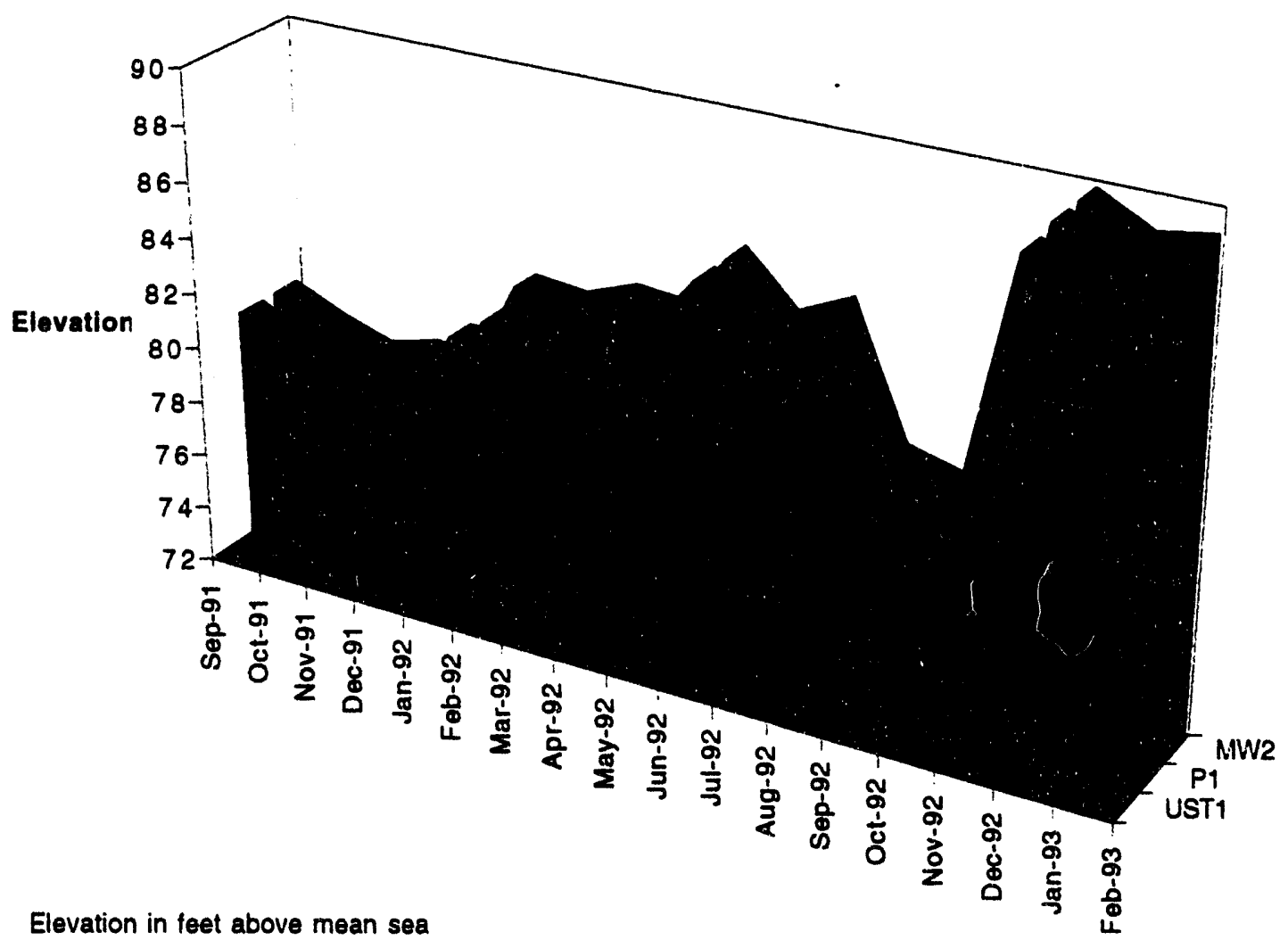

Figure 37. Monthly Water Elevations-Well UST1, P1, and MW2

129. 


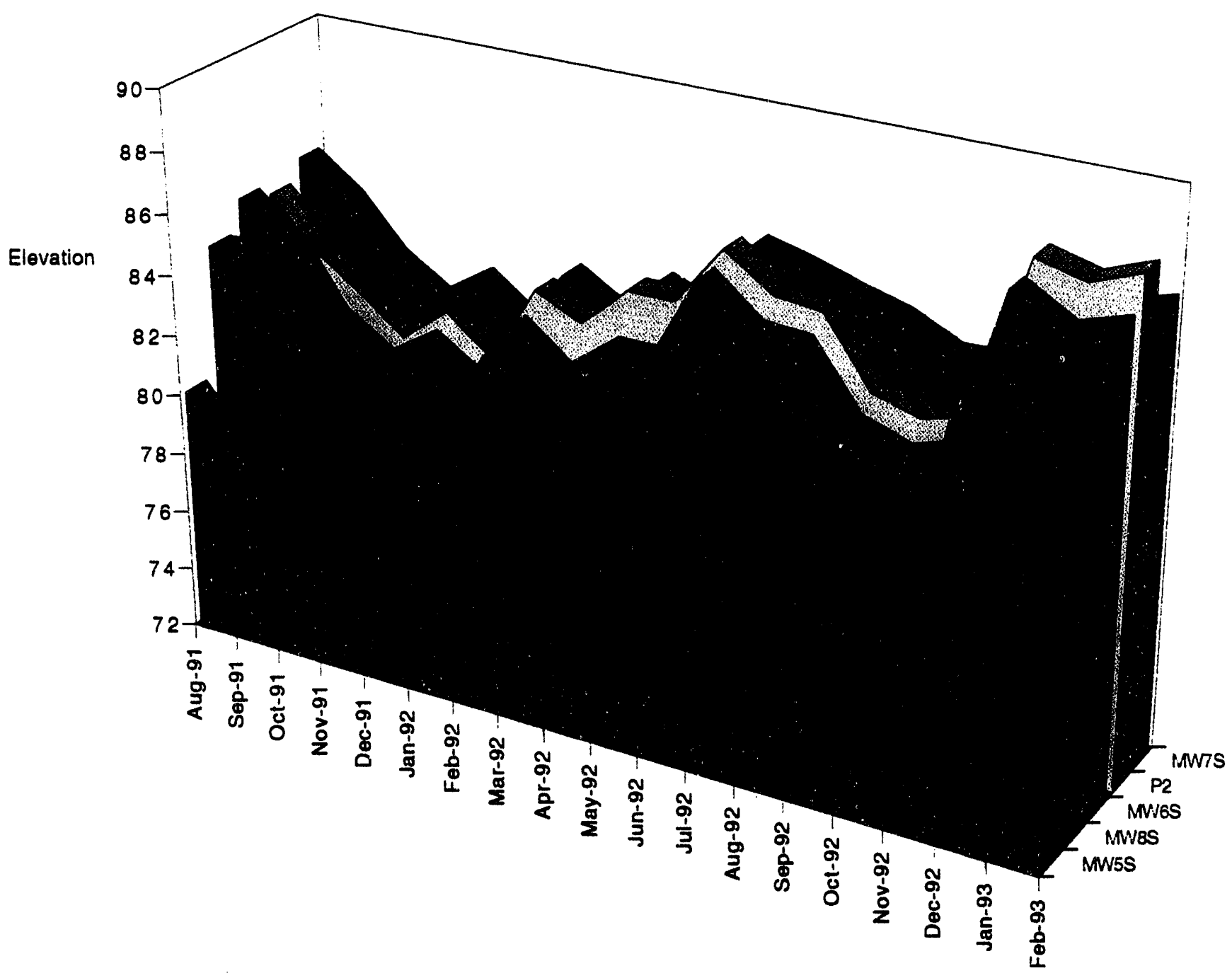

Elevations in feet above mean sea level

Figure 38. Monthly Water Elevations-Wells MW5S, MW6S, MW7S, MW8S, and P2 130. 




Elevations in teet above mean sea level

Figure 39. Monthly Water Elevations-Weils MW4, MW5I,MW61,MW7I, and MW8I 


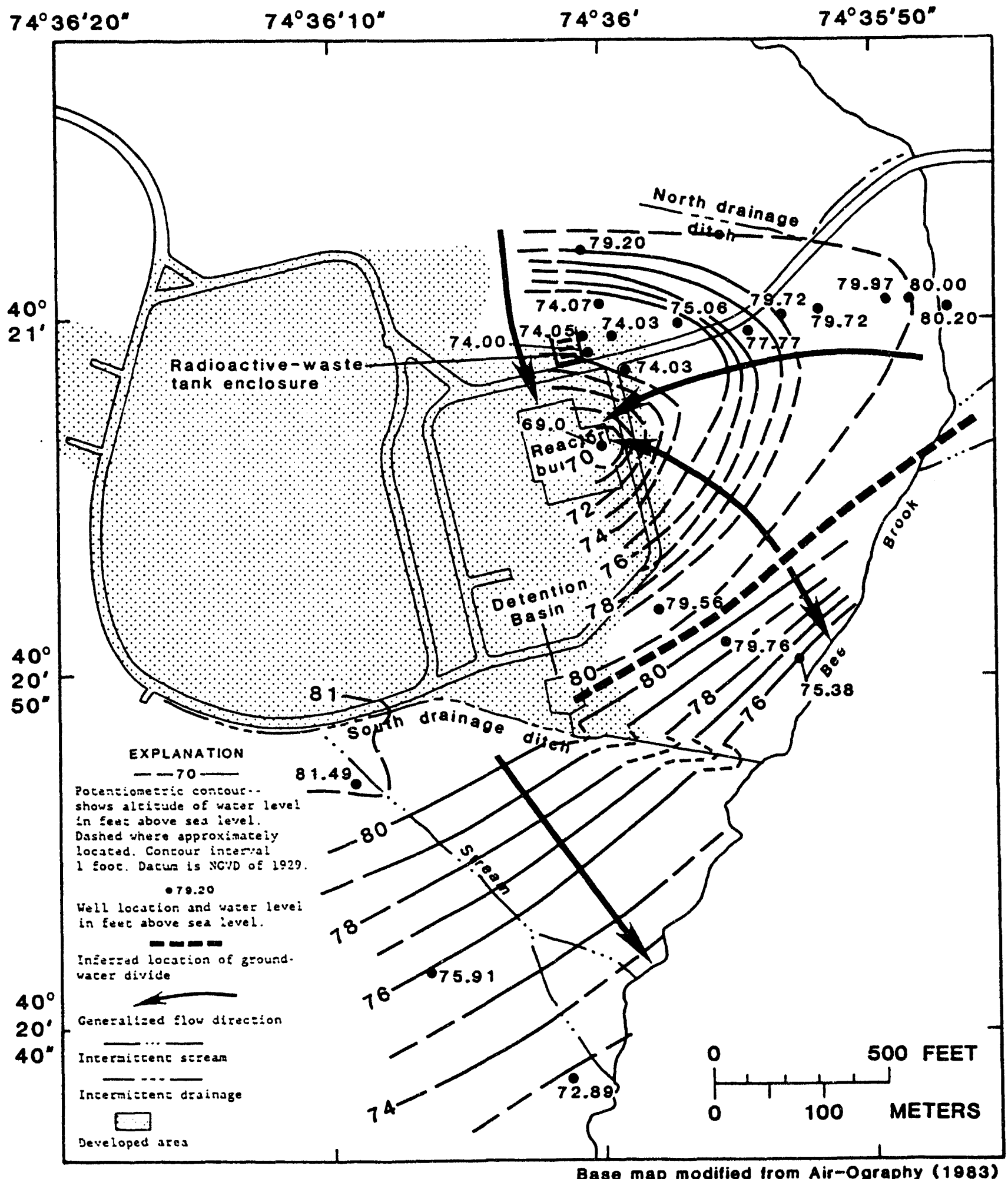

- Potentiometric surface of the bedrock aquifer, October 30, 1986.

Figure 40. Potentiometric Surface of the Bedrock Aquifer at PPPL 


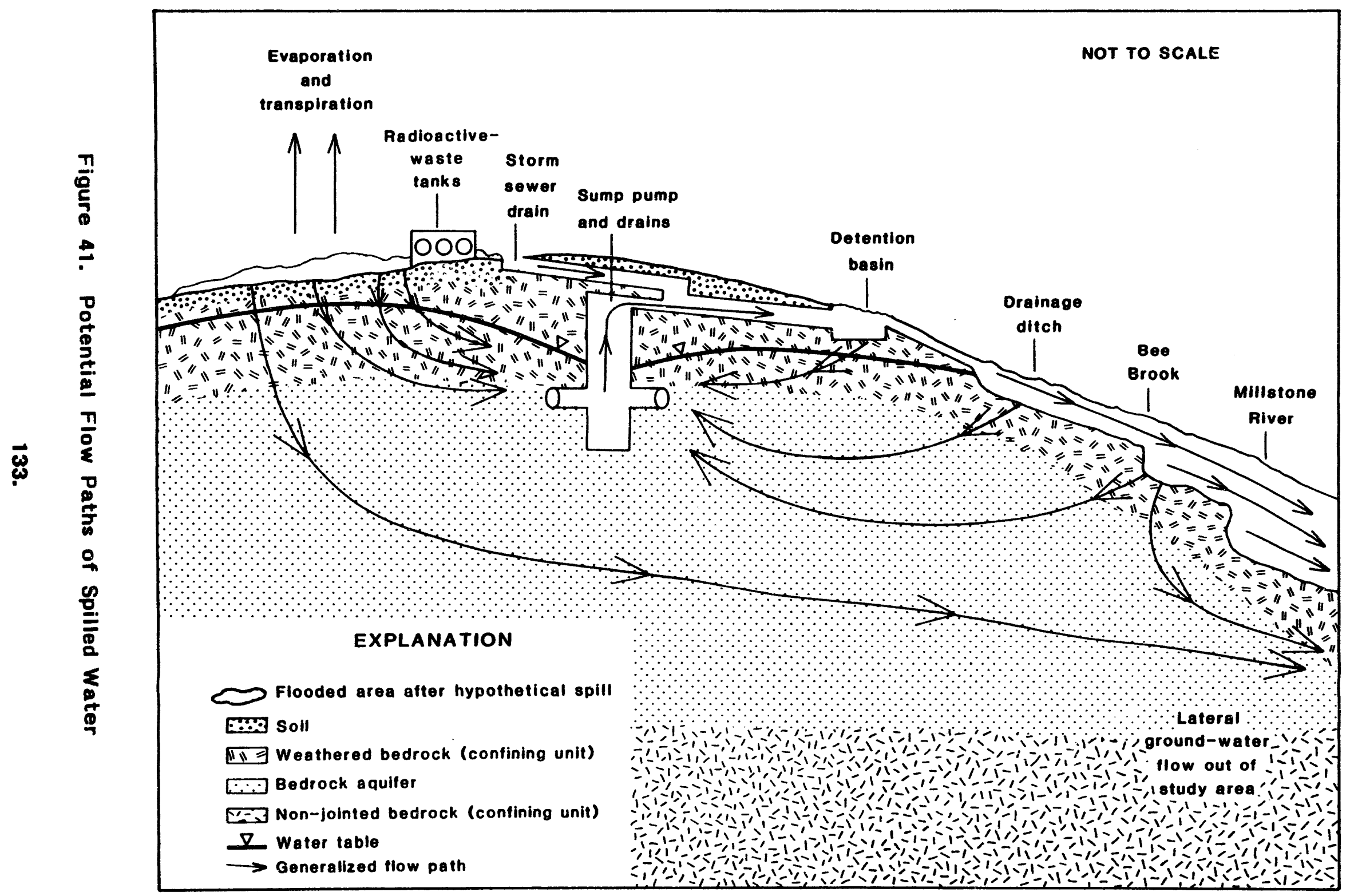

-Schematic representation of hydrogeologic framework and potential flow paths of spilled water. 







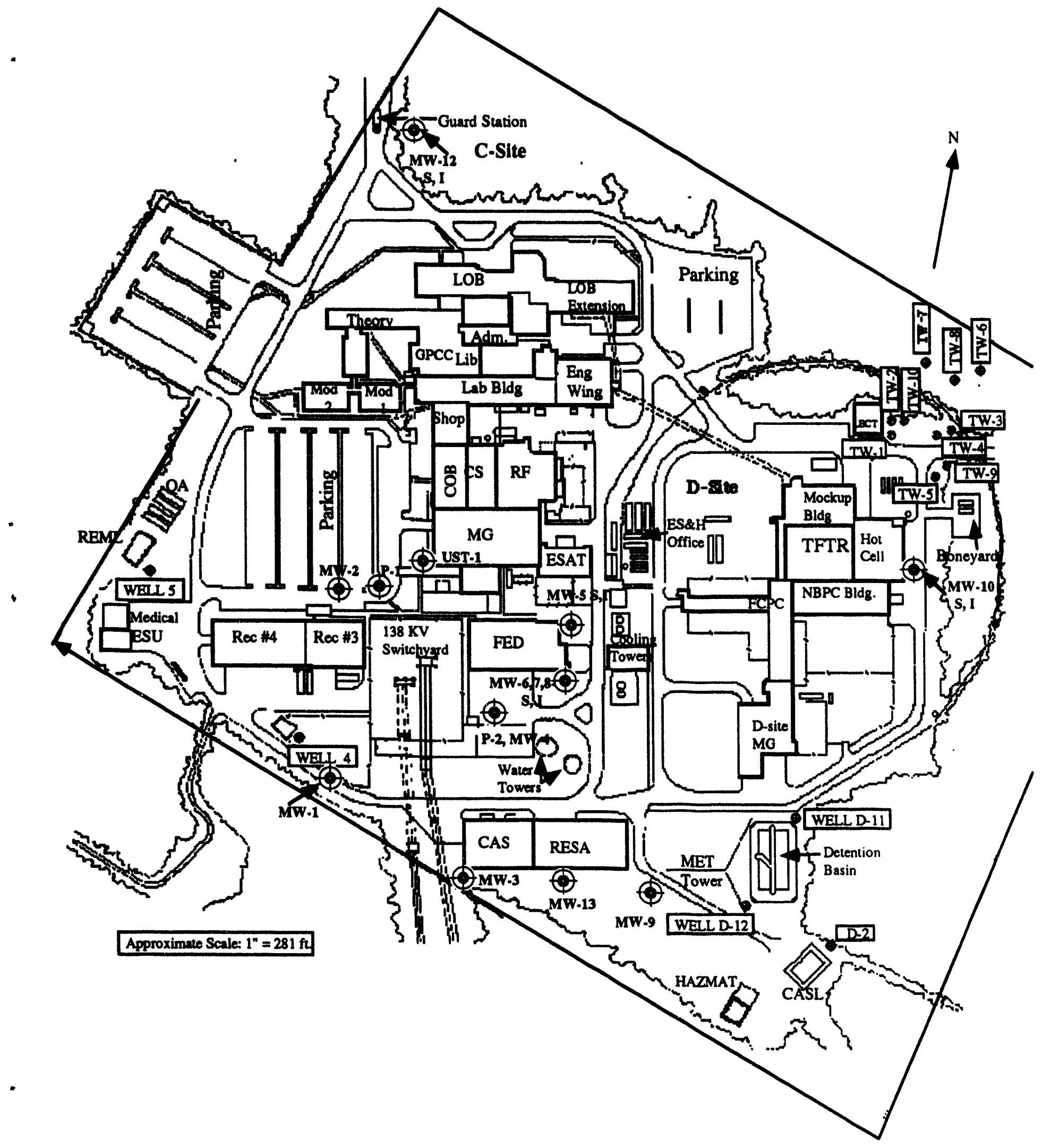

Figure 43. C and D site Monitoring Well Locations 


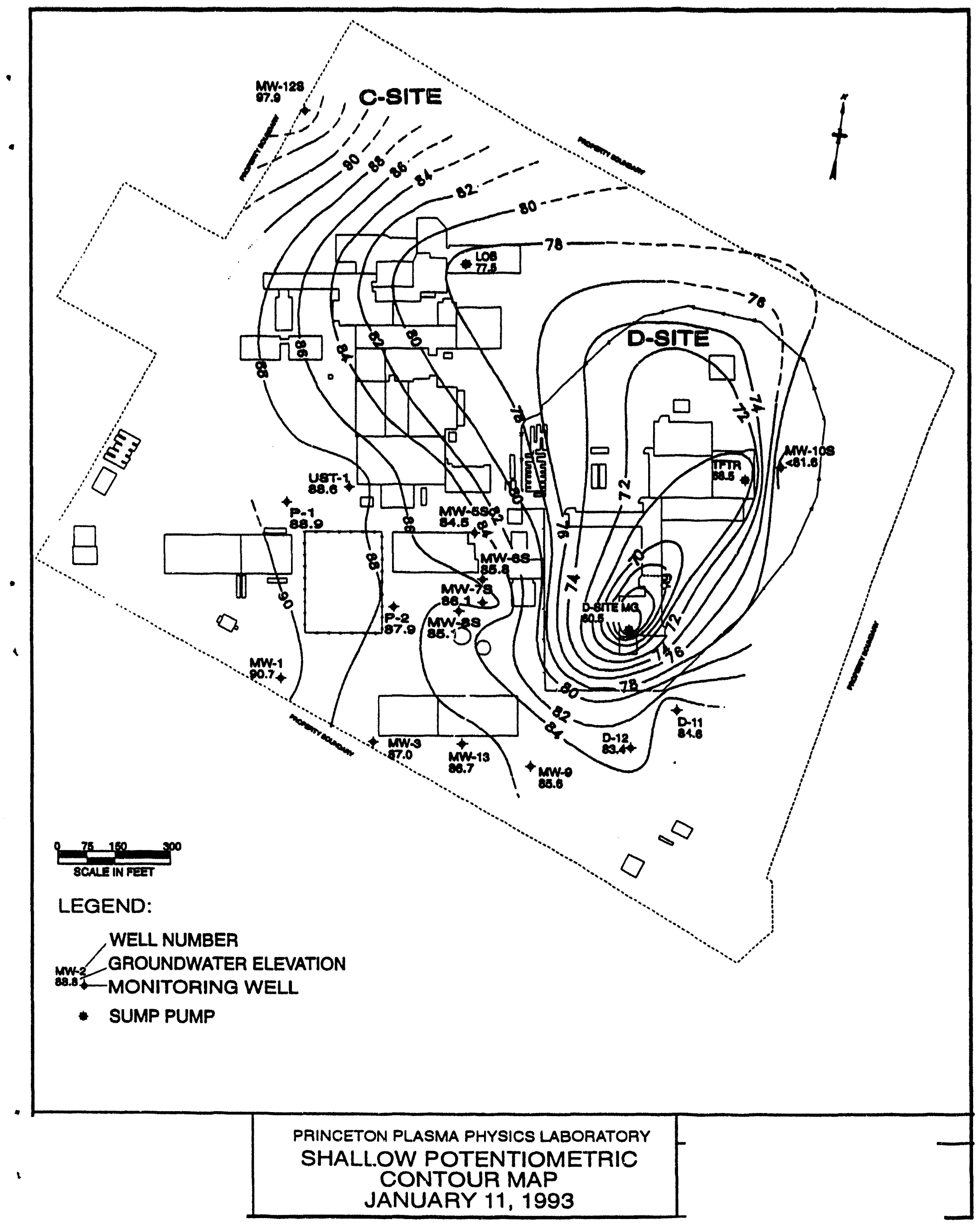

Figure 44. Shallow Groundwater Potentiometer Map, January 11, 1993 


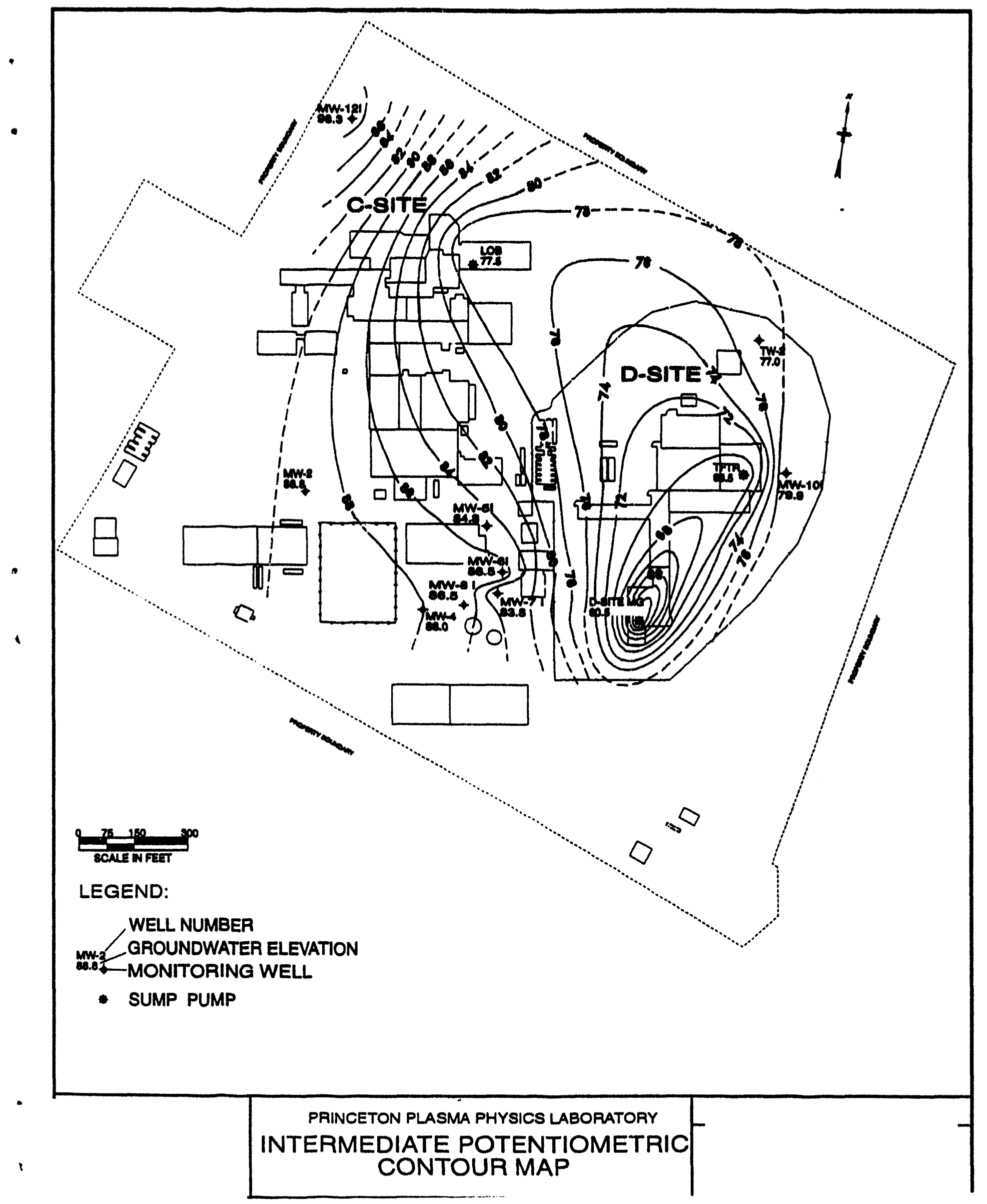

Figure 45. Intermediate Groundwater Potentiometer Map, January 11, 1993 


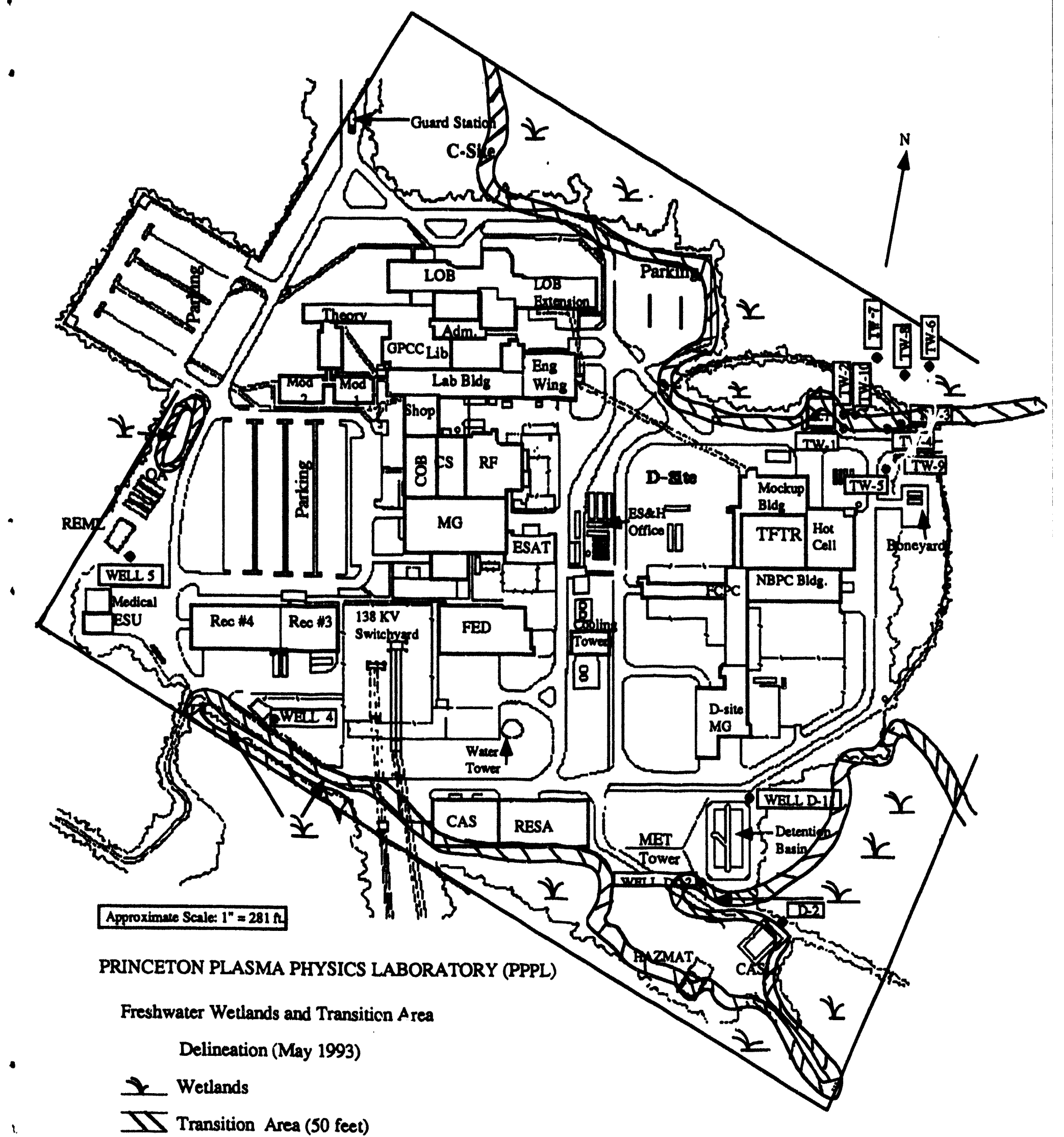

Figure 46. PPPL Wotland and Transition Area Boundaries 
Other Distribution

Argonne National Laboratory (R. Kolzow)

Battelle Pacific Northwest Laboratory (E. Eckert Hickey)

Brookhaven National Laboratory (J. Naidu)

CEBAF (C. Ficklen)

Congress (Sen. W. Bradley, Sen. F. Lautenberg, Rep. C. Smith)

Congressional Information Service (Joy Haftel)

DOE Chicago Field Operations [10]

DOE Environmental Audit, EH-24 [2]

DOE Office of Environmental Guidance and Compliance, EH-23 [5]

DOE Office of Fusion Energy, ER-55

DOE Office of NEPA Project Assistance, EH-25 [2]

DOE Princeton Area Office (J. Balodis) [10]

EPA/HQ (William Gunther)

EPA/Region II

Fermilab (J. Don Cossairt)

Forrestal Development Center (R. Wolf)

General Atomics (R. Savercool)

Lawrence Livermore National Laboratory (E. B. Hooper, Henry Bell)

Los Alamos National Laboratory (W. E. Quinn)

Idaho National Engineering Laboratory (L. Calwallader, G. Lonhurst, P. Ritter)

Massachusetts Institute of Technology (C. Fiore)

Middlesex County Health Department

NJDEPE, Bureau of Environmental Radiation (G. Nicolls)

NJDEPE, Bureau of Hazardous Waste Management

NJDEPE, Bureau of Planning and Site Assessment (L. Adams)

NJDEPE, Bureau of Groundwater Pollution Abatement (G. Nicholas)

NJDEPE, Bureau of Central Enforcement (G. Schussler)

NJOEM, Division of Law \& Public Safety (C. Williams)

NUS Savannah River (J. Fulmer)

Oak Ridge National Laboratory (J. Glowenika)

Plainsboro Township (Glenn Carter) [2]

The Princeton Packet (W. Plump)

SAIC (M. McKenzie-Carter)

SSC (L. Coulson)

BPPL/Princeton University:

H. L. Allen

J. W. Anderson

K. Buttolph

J. Caruso

R. C. Davidson

J. De Looper

A. R. De Meo

H. Ende

V. Finley

G. Gettelfinger

J. D. Gilbert

C. Gillars

S. M. Goldfeld [5]

R. Hawryluk
R.D. Holt

S. M. Iverson

C. Kircher

S. B. Larson

J. D. Levine

R. Kaeser

J. Malsbury

D. M. Meade

R. Ortego

P. H. Rutherford

N. Sauthoff

J. A. Schmidt

J. Scott

E. D. Simon
J. Sinnis

R. Shoe

W. Slavin

C. Smith

R. A. P. Sissingh

D. Speed

J. R. Stencel

M. Viola

J. Wheeler

A. White

M. Wieczorek

M. Williams

E. H. Winkler 

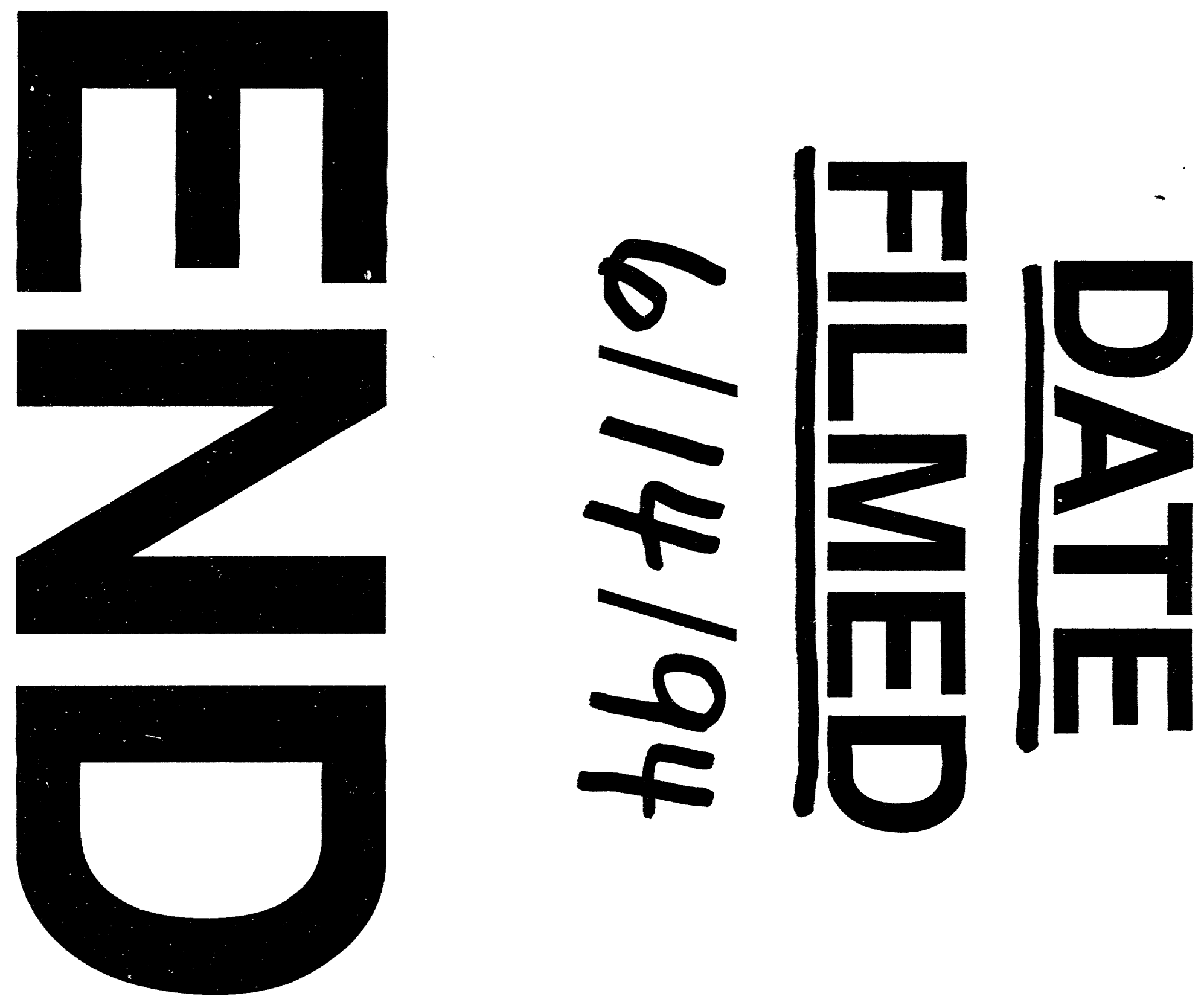


\section{1}

